\begin{abstract}
UNIVERSIDADE DE SÃO PAULO
FACULDADE DE FILOSOFIA, CIÊNCIAS E HUMANAS

DEPARTAMENTO DE LETRAS MODERNAS

PROGRAMA DE PÓS-GRADUAÇÃO EM ESTUDOS LINGUÍSTICOS E LITERÁRIOS EM INGLÊS
\end{abstract}

VALQUÍRIA DA SILVA MOISÉS

Do jeitinho brasileiro ao Brazilian little way:

uma leitura semiótica 


\author{
UNIVERSIDADE DE SÃO PAULO \\ FACULDADE DE FILOSOFIA, CIÊNCIAS E HUMANAS \\ DEPARTAMENTO DE LETRAS MODERNAS \\ PROGRAMA DE PÓS-GRADUAÇÃO EM ESTUDOS LINGUÍSTICOS E \\ LITERÁRIOS EM INGLÊS
}

\title{
Do jeitinho brasileiro ao Brazilian little way: uma leitura semiótica
}

Valquíria da Silva Moisés

Dissertação apresentada ao Programa de Pós-Graduação em Estudos Linguísticos e Literários em Inglês do Departamento de Letras Modernas da Faculdade de Filosofia, Letras e Ciências Humanas da Universidade de São Paulo, para obtenção do título de Mestre em Letras.

Orientadora: Profa. Dra. Elizabeth Harkot-de-La-Taille

São Paulo

2014 
NOME: MOISÉS, Valquíria da Silva

Título: Do jeitinho brasileiro ao Brazilian little way: uma leitura semiótica

Dissertação apresentada ao Programa de Pós-Graduação em Estudos Linguísticos e Literários em Inglês do Departamento de Letras Modernas da Faculdade de Filosofia, Letras e Ciências Humanas da Universidade de São Paulo, para obtenção do título de Mestre em Letras.

Aprovada em: /2014

Banca Examinadora

Profa. Dra. Elizabeth Harkot-de-La-Taille Instituição: Universidade de São Paulo (USP)

Julgamento: Assinatura:

Profa. Dra. Walkyria Maria Monte Mór

Instituição: Universidade de São Paulo (USP)

Julgamento: Assinatura:

Profa. Dra. Daniela Aparecida Vendramini Zanella Instituição: Universidade de Sorocaba (UNISO)

Julgamento: Assinatura: 
Ao meu pai, Zadir, e ao meu marido, Mauro (ambos in memorian), pela inspiração e motivação.

À minha mãe, Maria da Glória, pelo suporte incondicional, desde sempre.

Aos meus filhos, Gabriel e Rafael, pela presença, incentivo e apoio constantes.

À minha irmã, Maria do Socorro, ao meu cunhado, Aroldo, aos meus sobrinhos, Aroldo e Catarina, por me acompanharem em mais essa jornada.

À minha orientadora, Profa. Dra. Elizabeth Harkot-de-La-Taille, pelo acolhimento, pela confiança, dedicação e orientação. Pela compreensão do "jeito" e por respeitar o meu "jeito".

Aos professores do Departamento de Linguística e Semiótica e do Departamento de Letras Modernas, em especial à Prof. Dra. Walkyria Monte Mór.

À amiga e professora Maria Cristina Perez Vilas, pela dedicação e paciência com todos os meus "jeitos" e, algumas vezes, minha "falta de jeito".

Aos meus professores da UNISO, Beatriz Gama Rodrigues, Luiz Fernando Gomes, Paulo Edson Alves Filho, Daniela Zanella, Roberto Abdelnur Camargo pela dedicação e empenho em suas atividades docentes, fonte de inspiração.

Aos meus familiares, pelo incentivo, e em especial à Estela e Mariluce, ao Júlio e Ivete.

Aos amigos de outros tempos, Ana Lúcia, Paulo, Marli, Wilson, Marisa, Roberto, Danilo, João Luiz, Isaltino. João Daniel, Clarice, Juarez, Marili, Nancy, Fernanda, Flora. Diva, Benê, Fran, Yáscara, Ângela, Eliana, Flora Regina. À Regina, Cristina, Marisa.

Aos amigos de novos tempos, Paulinha, João, Danile, Viviane, Daniella.

Aos amigos geólogos que perduram, em especial ao Renato, Márcio, Vitor, Rivaldo, Mohamad, Mariana, Raquel, Nilvana e também à Virginia.

Aos meus amigos de jornada uspiana Adriano, Sara, Ilca e Ivair.

À CAPES, pela concessão de minha bolsa de estudos. 
"O jeitinho brasileiro desconsidera algumas normas, mas também cria condições para o desenvolvimento de novas potencialidades humanas, de novas habilidades".

Fernanda Borges 
MOISÉS, V. S. Do jeitinho brasileiro ao Brazilian little way: uma leitura semiótica. São Paulo: Universidade de São Paulo, Dissertação de mestrado, 2014, 191 p.

Este trabalho é o resultado de pesquisa sobre o fenômeno sociocultural conhecido como "jeitinho brasileiro". A análise foi realizada sob a perspectiva da semiótica discursiva francesa, desenvolvida por A. J. Greimas, tendo por objetivo a busca dos efeitos de sentido que o vocábulo e seus parassinônimos pudessem apresentar. O ponto de partida foi a representação gráfica mostrada por Barbosa (2006), que ilustra o continuum entre o favor e a corrupção, entre os quais o jeito está posicionado, percebido como positivo, quando se aproxima do favor, e negativo, quando próximo da corrupção. Segundo a autora, a passagem de uma categoria para outra deve-se ao contexto e a relação existente entre as pessoas de uma determinada situação. O tema do "jeitinho brasileiro" requereu um estudo sobre cidadania, na sociedade contemporânea, no tocante à hierarquia e à igualdade. Também abrangeu a problemática da sociedade líquido-moderna, apresentada por Z. Bauman, e o dilema da escolha entre o indivíduo e o cidadão. Para alcançar o objetivo de estudar o campo semântico e discursivo do vocábulo "jeitinho" e de seus parassinônimos, a minha escolha incidiu sobre o estudo de textos que ilustram diferentes situações de ocorrência e os efeitos de sentido que cada exemplo propicia. Os textos que compuseram o corpus da pesquisa, e nos quais pude identificar as variações do "jeitinho", permitiram expansão do eixo apresentado por Barbosa (2006). Dessa forma, propus uma gradação mais detalhada para a gama semântica do "jeitinho brasileiro", a partir da colocação de cada caso estudado em um ponto aproximado, entre o "favor" e a "corrupção". Solidariedade, sobrevivência, habilidade, criatividade, flexibilidade, improvisação, charme, simpatia, malandragem, prevaricação, hipocrisia, flexibilidade moral foram algumas das possibilidades presentes nos textos analisados.

Palavras-chave: jeitinho, jeitinho brasileiro, Brazilian way, cidadania, semiótica discursiva francesa. 
MOISÉS, V.S. From jeitinho brasileiro to the Brazilian little way: a semiotics reading. São Paulo: Universidade de São Paulo, Dissertação de mestrado, 2014, $191 \mathrm{p}$.

This essay is the result of a research about the sociocultural phenomenon known as "jeitinho brasileiro". The analysis was taken under the perspective of French discourse semiotics, developed by A. J. Greimas, having as objective the search for the meaning effects the word "jeitinho" and its "parasynonyms" could present. Its revisits Barbosa (2006) and her graphic representation that illustrates a continuum between favor and corruption, along which the "jeito" takes place, perceived as positive when close to favor or negative when close to corruption. According to the author, the shift from one category to another (favor to corruption and vice-versa) depends on the context and the relationship among the participants of a given situation. The theme "jeitinho brasileiro" also demanded studies about citizenship in contemporary society, focusing on hierarchy and equality. It has comprehended the problematical of the liquid modern society introduced by $Z$. Bauman and the dilemma in choosing to focus the individual or the citizen. To reach the objective of studying the semantic and discourse field of the word "jeitinho" and its "parasynonyms", my choice lay on the study of texts which illustrate different occurrences and the meaning effects each example allows for. The corpus provided us an expansion of the axis proposed by Barbosa (2006), by means of the variety of examples and usages identified. Thus, I propose a more detailed gradation to the semantic range of the "jeitinho brasileiro", by placing each study on an area between favor and corruption, according to the semantic field implied by each study. Solidarity, survival, roguery, "prevaricação", hypocrisy, moral flexibility were some of the possibilities presented in the texts analyzed.

Keywords: "jeitinho", "jeitinho brasileiro”, Brazilian way, citizenship, French discourse semiotics. 
O "jeitinho": pessoal ou impessoal; resistência, criatividade ou burla?

Objetivos e justificativa

Método e corpus.

1. O QUE É O “JEITINHO”

1.1 Introdução ao Estudo Lexical 47

1.20 "jeito" 49

1.3 Do "jeito" ao "jeitinho" 63

1.4 Do "Jeitinho" ao "Jeitinho Brasileiro" 67

1.5 Habilidade 73

1.6 Improviso 75

1.7 Flexibilidade 78

1.8 Criatividade 81

1.9 Favor. 85

1.10 Corrupção 88

1.11 Flexibilidade moral 94

1.12 Quanto jeito!!! 96

2. JEITO, JEITINHO, JEITINHO BRASILEIRO, BRAZILIAN (LITTLE) WAY. 98

2.1 Antonico, me faz um favor. 100

2.2 Soldados brasileiros durante a campanha dos Apeninos na Segunda Guerra Mundial: o "jeitinho", a criatividade e a sobrevivência 106

2.3 Na linha de produção: um caso de criatividade e jeitinho brasileiro 110

2.4 Moça deitada na grama: simpatia, charme e "jeitinho" 116 
2.6 Abrigo de vagabundos: "jeitinho", arranjo, prevaricação ou solidariedade e sobrevivência?

2.7 Jeitinho Brasileiro em uma canção: hipocrisia e corrupção... Não tem jeito?

2.8 Leitura do jeitinho brasileiro por estrangeiros 152

2.9 Afinal, como se diz "jeitinho brasileiro" em inglês? .............................. 161

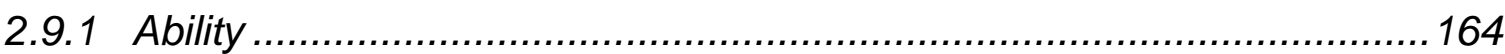

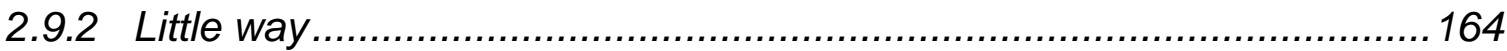

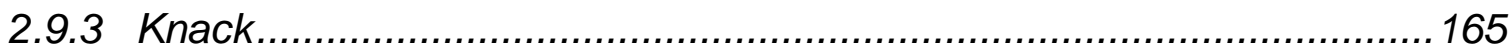

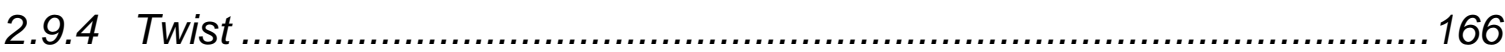

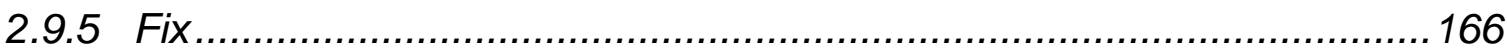

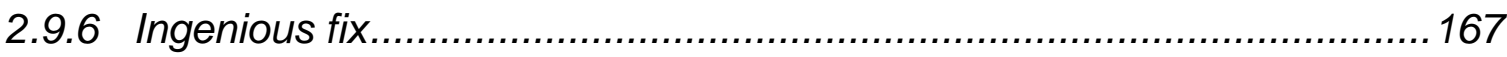

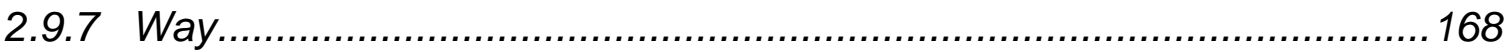

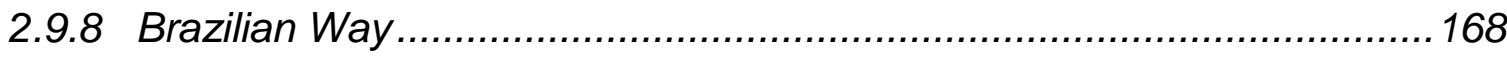

2.9 .9 Clever Dodge ................................................................................ 170

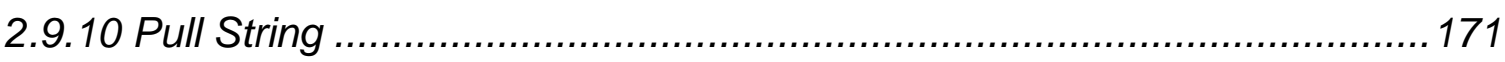

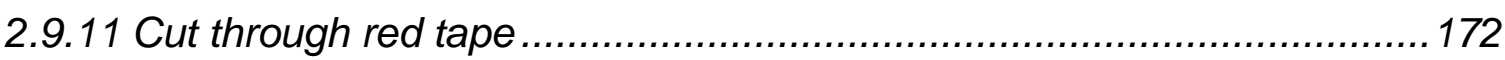

2.9.12 Work (sth) out; Have to; Help (sb) out; Get out of; Find a way round.... 173

2.9.13 Brazilian jeitinho ................................................................... 174

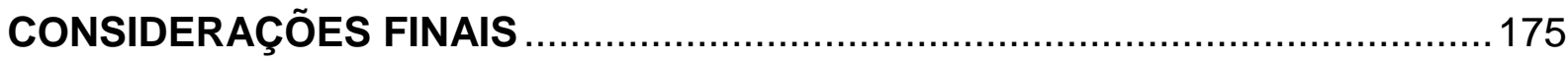

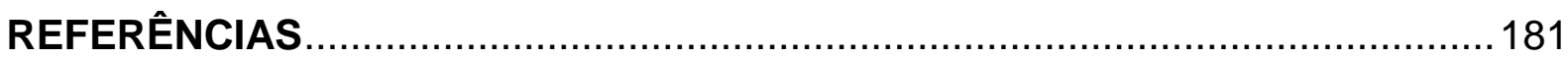

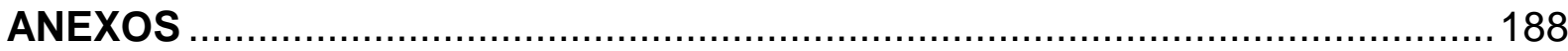




\section{INTRODUÇÃO}

\section{O "jeitinho": pessoal ou impessoal; resistência, criatividade ou burla?}

"Quebrar um galho". "Uma mão lava a outra”. "Quem não chora não mama”. "Na vida só não há remédio para a morte". "Chorar as pitangas". "Que vantagem Maria leva". "Aos amigos tudo, aos inimigos a lei". "Hoje é ele, mas amanhã pode ser eu". "Não nego nada a ninguém, ajudo a quem posso". "Todo mundo faz, não vou ficar de fora". "Quem usa é esperto, quem não usa é otário". "Mexer os pauzinhos". "A gente se vira". "Isso é apenas uma formalidade". "Vamos fazer um rolo". "De uma boa conversa ninguém escapa”.

Quem já não ouviu falar ou até fez uso de dizeres como estes? Todas essas expressões nos remetem ao que popularmente é conhecido como "jeitinho brasileiro".

Assim, a pesquisa sobre o "jeitinho brasileiro" decorre do anseio por discutir questões relacionadas aos valores e à ética em nossa sociedade. Por que especificamente o "jeitinho"?

O "jeitinho", tal como é visto a partir dessas frases, sempre me causou certo desconforto, e porque negar, até algum preconceito. Ele é considerado uma das formas representativas do modo de ser do brasileiro e no exterior é, muitas vezes, associado a uma forma nada lisonjeira de nos identificar. Nunca julguei que essa representação fosse apropriada, não só a mim, como a tantos outros brasileiros que têm seu comportamento pautado por normas, e não por ignorá-las. Enfim, compreendia o "jeitinho" como algo unicamente negativo.

Concebia cidadania como um sistema de leis e regras universais que vale para todos em todo e qualquer espaço social. Quando presenciava fatos rotineiros nos quais apenas o interesse pessoal era levado em conta, em detrimento do direito de todas as outras pessoas, a sensação de ter meus direitos deixados à margem por aqueles que julgavam serem capazes de se sobrepor, como se estivessem em um mundo em que a eles tudo fosse permitido, causava-me indignação. Seria como se fosse o mundo da casa ${ }^{1}$, em que as pessoas desse universo tudo pudessem.

\footnotetext{
${ }^{1}$ Roberto DaMatta (1986) retrata assim o 'mundo da casa': “... na casa podemos ter de tudo, como se ali o espaço fosse marcado por um supremo reconhecimento pessoal: uma espécie
} 
Como educadora e professora de língua inglesa, sempre preocupei-me com a formação de alunos que desenvolvessem o senso crítico, com condições para refletir e discutir questões, fossem elas político-sociais, culturais ou de outra ordem, que fizessem parte do seu dia-a-dia; que fossem usuários competentes da língua materna e da língua de comunicação mundial, em uma era globalizada e multicultural. Dessa forma, meu projeto educacional esboçou-se com o objetivo de colaborar na formação de indivíduos para o exercício de uma cidadania plena e do mundo.

Entretanto, a preocupação com a formação integral do cidadão por meio da educação e a discussão sobre a cidadania e seu exercício não está restrita apenas ao ambiente educacional, é um anseio de toda sociedade.

Procurar respostas para a pergunta "como a escola favorece o exercício da cidadania?" foi o início do meu percurso na pesquisa.

Primeiramente, procurei responder à questão "o que é cidadania?". Cidadania $^{2}$ provém do latim, civita, relativo à cidade, e conferida a um indivíduo, a palavra serve para classificá-lo na esfera pública.

Com o intuito de enriquecer o debate, e estabelecer um diálogo entre diferentes autores brasileiros sobre o tema, apresento algumas definições de cidadania.

Para o escritor e historiador Jaime Pinsky,

Ser cidadão é ter direito à vida, à liberdade, à propriedade, à igualdade perante a lei: é, em resumo, ter direitos civis. É também participar no destino da sociedade, votar e ser votado, ter direitos políticos, [e] direitos sociais, aqueles que garantem a participação do indivíduo na riqueza coletiva: o direito à educação, ao trabalho, ao salário justo, à saúde e uma velhice tranquila. Exercer a cidadania plena é ter direitos civis, políticos e sociais (PINSKY, 2008, p. 9).

Já para o jurista Dalmo Dallari:

A cidadania expressa um conjunto de direitos que dá à pessoa a possibilidade de participar ativamente da vida e do governo do seu povo.

de supercidadania que contrasta terrivelmente com a ausência total de reconhecimento que existe na rua." (p. 28)

${ }^{2}$ Cidadania, segundo Houaiss, é a "condição de pessoa que, como membro de um Estado, se acha no gozo de direitos que lhe permitem participar da vida política". Cidadão é o "indivíduo que, como membro de um Estado, usufrui de direitos civis e políticos por este garantidos e desempenha os deveres que, nesta condição, Ihe são atribuídos". 
Quem não tem cidadania está marginalizado ou excluído da vida social e da tomada de decisões, ficando numa posição de inferioridade dentro do grupo social (DALLARI, 1998, p.14).

A socióloga e educadora Maria Victória Benevides assim discorre sobre o tema:

\begin{abstract}
O cidadão, além de ser alguém que exerce direitos, cumpre deveres ou goza de liberdades em relação ao Estado, é também titular, ainda que parcialmente, de uma função ou poder público. Isso significa que a antiga e persistente distinção entre a esfera do Estado e a da Sociedade Civil esbate-se, perdendo a tradicional nitidez. Além disso, essa possibilidade de participação direta no exercício do poder político confirma a soberania popular como elemento essencial da democracia. Reforça, ademais, a importância de se somarem direitos políticos aos direitos sociais - pois os direitos políticos favorecem a organização para a reclamação dos direitos sociais. Como lembra Marilena Chauí, a cidadania se define pelos princípios da democracia, significando necessariamente conquista e consolidação social e política. A cidadania exige instituições, mediações e comportamentos próprios, constituindo-se na criação de espaços sociais de lutas (movimentos sociais, sindicais e populares) e na definição de instituições permanentes para a expressão política, como partidos, legislação e órgãos do poder público. Distingue-se, portanto, a cidadania passiva - aquela que é outorgada pelo Estado, com a ideia moral do favor e da tutela - da cidadania ativa, aquela que institui o cidadão como portador de direitos e deveres, mas essencialmente criador de direitos para abrir novos espaços de participação política (BENEVIDES, 1994, p. 9).
\end{abstract}

A cientista social Maria de Lourdes Manzini Covre, após discutir diversas definições de cidadania, em diferentes regimes, sistemas políticos, classes sociais e contextos históricos, apresenta, como síntese, o que se segue:

A cidadania é o próprio direito à vida no sentido pleno. Trata-se de um direito que precisa ser construído coletivamente, não só em termos do atendimento às necessidades básicas, mas de acesso a todos os níveis de existência, incluindo o mais abrangente, o papel do(s) homem(s) no Universo (COVRE, 2002, p. 11).

Assim, a partir do quadro apresentado, analiso as definições, comparando-as entre si, buscando resposta para a pergunta "o que é cidadania".

Entre os autores citados, todos parecem considerar a cidadania como sinônimo de participação. Ela é construída, conquistada, a partir da capacidade de organização, participação e intervenção social.

Em que pesem as diferenças filosóficas de cada autor, é no âmbito dos direitos que a cidadania se constitui. Ou seja, cidadão é aquele que exerce direitos, 
mas principalmente aquele que conquista, amplia, cria novos direitos, a partir do direito básico, que são os Direitos Humanos.

Contudo, além de direitos, cidadania envolve também deveres. Há uma reciprocidade entre eles. Conforme afirma Pinsky (1998):

\begin{abstract}
Exigir direitos é parte da cidadania, mas respeitar os contratos sociais é sua contrapartida. Talvez por fazermos a nossa parte ou não termos a consciência de pertencer a um coletivo é que somos tão condescendentes com irregularidades que acabam prejudicando todos. E o fato de mantermos a maioria da população sem os direitos básicos de cidadania nos impede de construir a Nação-cidadã que arrotamos desejar (PINSKY, 1998, p. 19).
\end{abstract}

O autor, acima, sinaliza um dos maiores problemas que permeia a sociedade brasileira, e que, de certa forma, dificulta a participação do sujeito para conquista da cidadania: a ausência dos direitos básicos. Sem direitos, o indivíduo busca solução para seus problemas como pode, da forma que dá. Dá um jeito...

Na procura dos motivos que dificultam o acesso da maioria da população aos direitos básicos, julguei importante fazer uma reflexão acerca de uma prática da História do Brasil. Entre as heranças deixadas pelos colonizadores portugueses está o patrimonialismo. À época do Império era difícil para os indivíduos que ocupavam posições públicas fazerem distinção entre o público e o privado, pois foram formados em um ambiente no qual tal diferenciação não se fazia presente, conforme cita Holanda (1995), em seu livro Raízes do Brasil: "A escolha dos homens que irão exercer funções públicas faz-se de acordo com a confiança que merecem os candidatos, e muito menos de acordo com as suas capacidades próprias" (HOLANDA, 1995, p. 145).

É fato que a nossa sociedade está historicamente calcada nos interesses do indivíduo em detrimento do coletivo, o privado se sobrepõe ao público, e isso traz reflexo para a sociedade atual. Zanella (2008), em um artigo sobre educação e cidadania, discute o patrimonialismo histórico na cultura brasileira:

Como resultado dessa herança, vemos obliterado o reconhecimento e consciência do direito à cidadania. Bom retrato dessas características são os costumes e frases que, incorporadas ao nosso cotidiano, apresentam-se como faceta do patrimonialismo que marca nossa cultura: o "jeitinho", a noção de que "o melhor é levar vantagem em tudo, certo?", as formas de resolver conflitos pautadas no bordão "você sabe com quem está falando?" (ZANELLA, 2008, p.87). 
Enquanto a autora descreve os resultados do comportamento do brasileiro, em relação ao interesse coletivo, oriundo do patrimonialismo, Carvalho aponta suas causas em dois momentos históricos diferentes. No primeiro:

\begin{abstract}
Diante dessa realidade, as elites ilustradas, agentes da modernização, de cima para baixo, se mostraram muito mais eficientes em cooptar setores dominantes do que em atrair a população para dentro do sistema. A maioria da população, excluída do voto, em 1881, viu, sim, a cara do Estado, e neste sentido, que se pode chamar de fraco, passou a condição de súdita. No episódio da guerra, é possível mesmo que o Estado, ou pelo menos os símbolos nacionais que ele administrava, tenham exercido alguma atração. Mas, pelo resto, a cara do Estado que a população viu era pouco atraente, como no serviço da Guarda, na exigência de registro civil, no recenseamento. Em alguns casos, penso sobretudo no recrutamento, ela era repulsiva. As leis reformadoras e os novos deveres cívicos introduziam na vida cotidiana mudanças cujo sentido não era compreendido. Nesse sentido é que foi usada a expressão de cidadãos em negativo. Havia um potencial de participação que não encontrava canais de expressão dentro do arcabouço institucional e que, também, não tinha condições de articular arcabouço alternativo. O brasileiro foi forçado a tomar conhecimento do Estado e das decisões políticas, mas de maneira a não desenvolver lealdade em relação às instituições (CARVALHO, 1996, p. 356).
\end{abstract}

Conforme aponta o autor, no século XIX, no Brasil, os principais pontos de contato entre o "cidadão" e o Estado foram a Guarda Nacional, o serviço militar, o serviço de júri, o recenseamento, o registro civil, além da política de votar e ser votado. Assim, a centralidade do Estado não indicava seu caráter público e universalista, pois ele era muito mais eficiente em "cooptar setores dominantes do que em atrair a população para dentro do sistema” (p. 356). Dessa forma, há a predominância de uma cultura política súdita, ou como afirma Carvalho de uma "cidadania construída de cima para baixo"3.

${ }^{3}$ José Murilo de Carvalho afirma a importância de alguns movimentos que atuavam de baixo para cima e que não podem deixar de ser chamados de cidadania, mesmo que em negativo: "Em todos esses movimentos, e em outros ainda maiores que se deram após a queda do Império, como a guerra de Canudos de 1897 e a revolta da Vacina de 1904, não se pode dizer que houve arbítrio da parte do governo, pelo menos até que a revolta se estabelecesse. Tratava-se de iniciativas que todos os Estados iam tomando à medida que burocratizavam e secularizavam os serviços públicos retirando-os das mãos da Igreja e dos grandes proprietários. Algumas dessas iniciativas, como a do registro civil, como observa Noiriel, eram condição para a garantia judicial de vários direitos civis e mesmo de direitos políticos. Mas eram ao mesmo tempo mudanças que interferiam no cotidiano dos cidadãos, alteravam comportamentos tradicionais, aumentavam o controle do governo e despertavam insegurança. Elas estendiam as malhas do governo e tiravam as pessoas de seu mundo privado, colocando-as dentro do campo da cidadania civil. Representavam a criação de cidadania de cima para baixo. As reações a elas não podem, no entanto, ser consideradas simplesmente como recusa de cidadania. Elas eram sem dúvida recusa de uma regulação vinda de cima, sem consulta e sem respeito por costumes e valores adicionais. Se é verdade que as revoltas não propunham alternativa, que se limitavam à recusa, também é verdade que traziam implícita a ideia de um pacto não escrito, 
No segundo momento, Carvalho discorre:

A cronologia e a lógica da sequência descrita por Marshall foram invertidas no Brasil. Aqui, primeiro vieram os direitos sociais, implantados em período de supressão dos direitos políticos e de redução dos direitos civis por um ditador que se tornou popular. Depois vieram os direitos políticos, de maneira também bizarra. A maior expansão do direito do voto deu-se em outro período ditatorial, em que órgãos de representação política foram transformados em peça decorativa do regime. Finalmente, ainda hoje, muitos direitos civis, a base da sequência de Marshall, continuam inacessíveis à maioria da população. A pirâmide dos direitos foi colocada de cabeça para baixo (CARVALHO, 2010, p. 219).

Segundo Carvalho (2010), ocorreu uma extrema centralização e valorização do Executivo como um dos resultados de longos e repetidos períodos ditatoriais. Isto favoreceu a criação da imagem do Estado todo poderoso, paternalista, distribuidor de empregos e favores, passando o Executivo a ser visto como o ramo do poder do qual vale a pena se aproximar. Segundo Carvalho (1996), "os cidadãos buscam o Estado para o atendimento de interesses privados" (CARVALHO, 1996, p. 339).

Souza (2008) também apresenta exemplo de lei que, atualmente, na vida cotidiana, se não compreendida, encontra resistência por parte da população: a Lei Seca ${ }^{4}$. Promulgada em 2008, e modificada em 2011, para torná-la mais rígida, até recentemente algumas pessoas procuravam formas de burlá-la. Uma delas seria a comunicação através de aplicativos para telefones celulares que permitiriam a divulgação de informação sobre a localização de blitze da polícia para flagrar os infratores.

Partindo do exemplo dado, pergunto: Por que uma lei cai em descrédito? Quando se estabelece rigor no cumprimento da lei, abre-se precedente para a corrupção burocrática. No mesmo site $^{5}$ em que se pesquisa sobre a lei seca, e no qual se discorre sobre seu conteúdo, já existem links que possibilitam o acesso aos modelos de formulários para se recorrer das multas referentes às infrações da mesma lei. Ainda, no que se refere ao não cumprimento da lei, em todo seu rigor,

preexistente, segundo o qual o governo não tinha o direito de interferir no cotidiano das pessoas e desrespeitar suas tradições. Dizendo não, os rebeldes estavam de alguma maneira afumando direitos, estavam fazendo política para garantir direitos tradicionais (CARVALHO, 1996, p. 354).

${ }^{4}$ Lei seca: Lei no 11.705 do Código de Trânsito Brasileiro, de 19 de junho de 2008, e modificada em 16 de novembro de 2011. Com esta nova legislação, o motorista que for flagrado com nível de álcool acima do permitido $(0,1 \mathrm{mg} / \mathrm{l}$ de sangue) terá que pagar uma multa, terá o carro apreendido e ainda perde a habilitação. A pior consequência é para quem estiver embriagado (níveis acima de $0,3 \mathrm{mg} / \mathrm{l}$ ): o motorista corre o risco de ser preso, e a detenção é de 6 meses a 1 ano.

${ }^{5}$ Disponível em: <http://www.brasilescola.com/quimica/lei-seca.htm>. Acesso em 14 mai. 2014. 
igual e indistintamente, para todos os seus cidadãos, tal fato pode gerar desconfiança em relação ao poder público.

A propósito da temática da cidadania, o "jeitinho" pode nos conduzir a uma discussão sobre a igualdade na sociedade brasileira. A autora do livro $O$ jeitinho brasileiro: a arte de ser mais igual do que os outros ${ }^{6}$, Lívia Barbosa (2006), já, a partir do título aborda uma questão primordial para a discussão: o que é ser mais igual? Por que mais igual? Assim a autora discorre sobre o que afirma ser a tese da igualdade:

O que afirmo nesta tese é que em primeiro lugar o jeitinho é um mecanismo que transforma indivíduos em pessoas, escorando-se em um discurso de igualdade entre os seres humanos e na capacidade de eles se colocarem no lugar dos outros. Em segundo lugar, afirmo que a concepção brasileira de igualdade é o atributo do individualismo mais enfatizado simbolicamente pela sociedade brasileira. E, em terceiro lugar, afirmo que a concepção brasileira de igualdade é de igualdade substantiva, predominantemente, em relação a outros tipos como, por exemplo, igualdade de oportunidade (BARBOSA, 2006, p. XVI).

Essa temática da igualdade traz à tona o domínio da burocracia, por ser nesta área onde mais se vê proliferar o expediente do "dar um jeito". A organização burocrática brasileira pauta-se pela rigidez e formalismo, e procura prever todas as situações possíveis. Praticamente cada situação da vida do cidadão requer algum procedimento burocrático. São tantas exigências e provas em contrário... E o Estado se coloca na posição de quem desconfia. A recíproca também é verdadeira: o cidadão se vê cercado de exigências que são, muitas vezes, difíceis de cumprir. Ele se sente acuado, sem nenhum respaldo, e se vê obrigado a lançar mão dos mais variados subterfúgios.

É então que o cidadão recorre à busca de soluções que deixam para trás questões valorizadas pela burocracia como a impessoalidade, a racionalidade e o anonimato. Portanto, ignora-se a igualdade apregoada pela cidadania, e busca-se, por exemplo, através do despachante - o profissional do "jeitinho" - resolver

\footnotetext{
${ }^{6}$ Subtítulo com clara menção à obra de George Orwell, A revolução dos bichos, de 1945. No livro, alguns animais, a propósito do sonho de viverem em uma sociedade mais igualitária e justa, e de se livrarem do jugo humano, estabelecem alguns mandamentos para reger sua sociedade, entre eles, "todos os animais são iguais". Porém, os porcos, ao assumirem o poder, estabelecem um regime mais opressor e cruel que o dos homens, e o mandamento passa a ser: "Todos os animais são iguais mas alguns são mais iguais que os outros". Lívia Barbosa parece fazer um convite à reflexão sobre a condição de desigualdade de direitos que permeia a sociedade brasileira.
} 
situações. Outro recurso utilizado nessas circunstâncias são as relações pessoais: recorrer a algum amigo que tenha influência, ou ao amigo de um amigo. Ainda podese fazer uso de certas categorias emocionais como o charme, a simpatia, a maneira de falar, tentando, por meio dessa interação, angariar solidariedade para a causa em questão.

Talvez esse seja o limiar entre o domínio do pessoal e do impessoal, da pessoa e do indivíduo. Talvez, nesse ponto, a discussão sobre a igualdade não seja mais necessária.

O antropólogo Roberto DaMatta, estudioso do "jeitinho" e seus desdobramentos, assim escreveu, sobre o que ele nomeou como dilema brasileiro:

\begin{abstract}
O dilema brasileiro residia numa trágica oscilação entre um esqueleto nacional feito de leis universais cujo sujeito era o indivíduo e situações onde cada qual se salvava e se despachava como podia, utilizando para isso o seu sistema de relações pessoais. Haveria assim, nessa colocação, um verdadeiro combate entre as leis que devem valer para todos e relações que evidentemente só podem funcionar para quem as tem. O resultado é um sistema social dividido e até mesmo equilibrado entre duas unidades sociais básicas: o indivíduo (o sujeito das leis universais que modernizam a sociedade) e a pessoa (o sujeito das relações sociais que conduz ao polo tradicional do sistema). Entre os dois, o coração dos brasileiros balança. $\mathrm{E}$ no meio dos dois, a malandragem, o "jeitinho" e o famoso e antipático "sabe com quem está falando?" seriam modos de enfrentar essas contradições e paradoxos de modo tipicamente brasileiro. Ou seja: fazendo uma mediação também pessoal entre a lei, a situação onde ela deveria aplicar-se e as pessoas nela implicadas, de tal sorte que nada se modifique, apenas ficando a lei um pouco desmoralizada mas, como ela é insensível e não é gente como nós, todo mundo fica, como se diz, numa boa, e a vida retorna ao seu normal... (DAMATTA, 1986, p. 97-98).
\end{abstract}

Compreendido dessa forma, o "jeitinho" é um mecanismo que transforma indivíduos em pessoas, uma vez que quem o usa se destaca, se separa dos demais membros da sociedade para se tornar uma pessoa com tratamento diferenciado, deixando de se submeter às leis universalizantes e impessoais às quais todos os cidadãos estão submetidos.

A dificuldade que o brasileiro tem em lidar com a hierarquia também é fator determinante para a distinção entre indivíduo e pessoa. A esperança em receber uma "mão amiga" ou de que alguém "interceda por nós", fortalece e alimenta um sistema em que prevalecem as ações das pessoas, que não foram orientadas para seguir a lei, mas sim fazer uso de uma rede de relações. Retomando DaMatta 
(1986), eis como o autor retrata a questão da igualdade e hierarquia, indivíduo e pessoa na sociedade brasileira:

No sistema social brasileiro, então, a lei universalizante e igualitária é
utilizada frequentemente para servir como um elemento fundamental de
sujeição e diferenciação política e social. Em outras palavras, as leis só se
aplicam aos indivíduos e nunca às pessoas; ou, melhor ainda, receber a
letra fria e dura da lei é tornar-se imediatamente um indivíduo. Poder
personalizar a lei é sinal de que se é uma pessoa. [...] Fazer leis é, no
Brasil, uma atividade que tanto serve para atualizar ideais democráticos
quanto para impedir a organização e a reivindicação de certas camadas da
população. [...] - o sistema das leis que serve para todos e sobre o qual
todos estão de acordo - transforma-se num instrumento de aprisionamento
da massa que deve seguir a lei, sabendo que existem pessoas bem
relacionadas que nunca as obedecem. [...] Por termos leis geralmente
drásticas e impossíveis de serem rigorosamente acatadas, acabamos por
não cumprir a lei. E, assim sendo, utilizamos o clássico "jeitinho" que nada
mais é que uma variante cordial do "Você sabe com quem está falando?" e
outras formas mais autoritárias que facilitam e permitem pular a lei ou nela
abrir uma honrosa exceção que a confirma socialmente. Mas o uso do
"jeitinho" e do "Você sabe com quem está falando?" acaba por engendrar
um fenômeno muito conhecido e generalizado entre nós: a total
desconfiança nas regras e decretos universalizantes (DAMATTA, 1986,
p.184).

Conforme o que discorre DaMatta, é possível que um círculo vicioso seja formado, reafirmando o estado de coisas: confia-se na lei como o instrumento para mudar o mundo, inventam-se muitas leis e elas perdem sua eficácia, o que torna as relações pessoais cada vez mais fortes, e assim por diante...

Se é difícil para o brasileiro conviver com a hierarquia, o excesso de formalismo na condução da coisa pública também é mais uma das dificuldades que tenta suplantar.

Guerreiro Ramos (1966), sociólogo e político brasileiro, em seu livro sobre a administração pública brasileira, também associa o "jeitinho" ao excesso de formalismo. Eis algumas considerações que o autor apresenta:

O genuíno processo brasileiro de resolver dificuldades, a despeito do conteúdo das normas, códigos e leis. É exatamente o formalismo que acarreta a prática do "jeito". Em si mesmo, o formalismo é, como temos demonstrado, modalidade de estratégia. É uma estratégia primária. $\mathrm{O}$ "jeito" é uma estratégia de segundo grau, isto é, suscitada pelo formalismo. [...] O jeito é, no Brasil, processo nativo, criollo, de contornar uma dificuldade a despeito da lei e até mesmo contra ela (RAMOS, 1966, p. 380).

Já o economista, diplomata e político brasileiro, Roberto Campos, em seu livro A técnica e o riso (1966), escreve sobre a sociologia do jeito, e relata que tinha 
curiosidade em pesquisar as raízes sociológicas do fenômeno. Considera que duas podem ser as razões pelas quais ocorreu a instituição do jeitinho na sociedade brasileira e não nas de origem anglo-saxã: uma delas é que na Inglaterra, a burguesia mercantil estabeleceu normas jurídicas de validade mais universal; e outra seriam as diferentes atitudes entre latinos e anglo-saxões referentes à lei e ao fato social. Para os saxões a lei é uma cristalização de costumes, pois codifica o costume corrente; uma lei raramente é inexequível, enquanto que as constituições latinas são normativas e regulamentares.

Em suma, como decorrência do percurso da pesquisa, as leituras levaram-me a outras inquietações e questões:

O "jeitinho" não nos proporciona condições de alcançar a cidadania? O usuário do "jeitinho", de alguma forma, pode ser considerado menos cidadão? Ou ainda, dando eco ao questionamento de Zanella (2008), "aprendemos a ser cidadãos ou somos cidadãos quando aprendemos?" (ZANELLA, 2008, p. 88)

Mesmo ainda sem resposta às perguntas, foi importante observar que para diferentes autores (PINSKY, 2008; DALLARI, 1998; BENEVIDES, 1994; COVRE, 2002, CARVALHO, 2010), a cidadania no Brasil ainda está em processo de gestação, e de alguma forma, os ideais da Revolução Francesa - a liberdade, a igualdade e a fraternidade - que são os pilares da democracia moderna, aqui, ainda se encontram incipientes e distantes. É a presença desses ideais que garante a existência de cidadãos ativos, participantes.

A discussão sobre o fenômeno da cidadania ainda é um campo cheio de tensões e conflitos. José Murilo de Carvalho (2010) aponta essa problemática quando afirma que

Uma cidadania plena, que combine liberdade, participação e igualdade para todos, é um ideal desenvolvido no Ocidente e talvez inatingível. Mas ele tem servido de parâmetro para julgamento da qualidade da cidadania em cada país e em cada momento histórico.

Tornou-se costume desdobrar a cidadania em direitos civis, políticos e sociais. O cidadão pleno seria aquele que fosse titular dos três direitos (CARVALHO, 2010, p. 9).

Partindo-se do princípio que para ser considerado um cidadão pleno o indivíduo deve gozar dos seus direitos civis, políticos e sociais, o não acesso a algum desses direitos não permite que o indivíduo seja considerado cidadão? 
Como falar em "cidadão do mundo" (IANNI, 2003, p. 107) se, quando se analisa a perspectiva do que é considerado cidadão pleno, não se pode constatar a observância desses direitos para a grande parte da sociedade brasileira? O cidadão do mundo estaria inserido nesse sistema em escala global, com o respeito às leis, segundo a relação tempo e espaço (onde estou, o espaço que ocupo, a cultura na qual estou inserido, etc.)?

Como pode ser observado, o tema cidadão do mundo traz consigo um dilema, pois para ser um cidadão do mundo, o indivíduo tem de ter alcançado primeiramente a cidadania plena. A cidadania do mundo ainda é um esboço, está sendo criada, e “a Declaração Universal dos Direitos do Homem, promulgada pela ONU em 1948, permanece como uma declaração de intenções, de ideais, a despeito da sua importância social, política, econômica e cultural" (IANNI, 2003, p.111).

Ainda, segundo lanni (2003),

Os dilemas da cidadania, do cidadão do mundo, não se limitam aos aspectos políticos, ou jurídico-políticos; envolvem também os sociais, econômicos e culturais. À medida que caminha, o processo democrático necessariamente compreende todos os níveis da vida social, da esfera pública. Codificam-se democraticamente as relações, os processos e as estruturas que constituem e movimentam a sociedade em níveis nacional e mundial (IANNI, 2003, p.113).

Isto posto, como decorrência do percurso da pesquisa, a resposta à primeira pergunta proposta é salientar que a sala de aula é mais um espaço de reflexão sobre a cidadania, e que pode contribuir como espaço de participação. A escola não concede a cidadania, nem o professor dispõe dessa prerrogativa. Na sala de aula é possível ter acesso ao conhecimento; ela se constitui como espaço de reflexão e discussão de questões sociais, que podem incentivar uma leitura crítica da realidade. Essa vivência pode contribuir para que tais questões extrapolem os muros da escola, alcançando outros contextos, uma vez que a cidadania não pode ficar aí encerrada, apenas como conhecimento.

Assim, mesmo sabendo das limitações do trabalho docente na sala de aula, é também nesse espaço que pretendo contribuir como educadora e cidadã, que se constroem cotidianamente, inclusive com a elaboração deste trabalho.

Entretanto, é importante ressaltar uma nova realidade vivida e enfrentada pelas diferentes salas de aula, de diferentes escolas brasileiras, e que pode ter 
alterado a configuração do que é ser cidadão: a mudança de foco dos jovens. Bauman (2013) afirma que essa mudança de foco dos jovens pode ser definida como uma mudança da "relevância para a vida". Segundo o sociólogo,

\begin{abstract}
A forma de vida em que a geração jovem de hoje nasceu, de modo que não conhece nenhuma outra, é uma sociedade de consumidores e uma cultura "agorista" - inquieta e em perpétua mudança - que promove o culto da novidade e da contingência aleatória. Numa sociedade e numa cultura assim, nós sofremos com o suprimento excessivo de todas as coisas, tanto os objetos de desejo quanto os de conhecimento, e com a assombrosa velocidade dos novos objetos que chegam e que vão (BAUMAN, 2013, p. 24).
\end{abstract}

A efemeridade com que a sociedade tem encarado as coisas da vida, em que nada é permanente, parece temerária para o desenvolvimento de qualquer tipo de aprendizagem. Há excesso de informação, e esse excesso e a velocidade com que ocorre tornam difícil criar linhas de raciocínio e desenvolver narrativas. As ideias ficam fragmentadas, desconectadas.

Com toda a disponibilidade de tecnologias e vivendo, segundo Bauman (2007), em uma sociedade "líquido-moderna", "em que as condições sob as quais agem seus membros mudam num tempo mais curto do que aquele necessário para a consolidação, em hábitos e rotinas, das formas de agir" (BAUMAN, 2007, p. 07), fica difícil que todas as etapas necessárias para o aprendizado se concretizem. É, provavelmente, quando teremos a abertura de espaços para que se criem fragilidades. Acrescenta o autor que "a cultura líquido-moderna não se sente mais uma cultura da aprendizagem da acumulação, como as culturas registradas nos relatos dos historiadores e etnógrafos. Em vez disso, parece uma cultura do desengajamento, da descontinuidade e do esquecimento" (BAUMAN, 2013, p.36).

Nota-se, ainda, uma crise de autoridade, tanto na escola, quanto na sociedade, e também no nível das relações pessoais. O desafio às autoridades, à ordem imposta, torna-nos impotentes perante várias situações, e isso reflete na sala de aula, principalmente.

A respeito da crise de autoridade, segundo Goergen (2007),

As pessoas sentem-se órfãs de parâmetros de comportamento. Os mais jovens, vivendo o espírito da época, são contrários a qualquer tipo de autoridade. Os adultos sentem-se inseguros, desautorizados, sem saber o que dizer aos jovens. Serão corriqueiros o assombro e a desorientação das pessoas diante do futuro da sociedade se prosseguirem as práticas que 
afrontam qualquer sentido de bem comum, de justiça social. Por vezes, as pessoas parecem cansadas de lutar por uma sociedade melhor diante das dimensões assustadoras da barbárie; preferem desistir, encerrar-se na sua privacidade, abandonar o político, desestimuladas pela sensação de impotência perante as intermináveis séries de abusos que se sucedem diante de seus olhos. Embora seja compreensível, essa atitude encerra o grande risco de deixar o campo livre para que as contravenções sejam toleradas como uma rotina inevitável, contra a qual não há o que fazer. Penso que a luta em defesa de uma sociedade livre e justa não pode ser abandonada e acredito que à educação cabe um papel importante nessa tarefa (GOERGEN, 2007, p. 744).

Neste cenário de incertezas, em que vivemos uma nova ética e moral, tal discussão sobre a temática proposta pelo autor se faz importante na formação para a cidadania. A preocupação com a justiça social e a luta por uma sociedade livre cabem à educação, inclusive para que os abusos e contravenções, citados por Goergen (2007), não venham a ocorrer, nem passem a ser tolerados...

Na sociedade contemporânea, se pensarmos que vivemos a emergência de uma sociedade líquido-moderna, consumista, e em crise de identidade e de autoridade, "em que tudo o que é estabelecido logo se desfaz; uma sociedade em que o privado se sobrepõe ao público" (GOERGEN, 2007, p. 744), seria correto atribuir ao "jeitinho" o papel de vilão na composição da sociedade brasileira e de seu povo?

Assim como "de uma boa conversa ninguém escapa", também não pude deixar de me submeter à necessidade de examinar o "jeitinho" para além da conotação negativa. Por que "a gente se vira", "quebra um galho", "faz uma gambiarra" não podem expressar um "jeitinho" criativo, que caracteriza a habilidade de improvisação atribuída ao povo brasileiro? Podem esses diferentes "jeitinhos" coexistir sob a égide da ética ${ }^{7}$ ?

A leitura de textos de pesquisadores de diversas áreas das Ciências Humanas $^{8}$, que com diferentes abordagens apresentam a história da formação e desenvolvimento do povo brasileiro, propiciaram-me as condições de ampliar a visão que tinha sobre o assunto: Sérgio Buarque de Holanda (1995), Gilberto Freyre

\footnotetext{
${ }^{7}$ Em Houaiss, ética é: 1. parte da filosofia responsável pela investigação dos princípios que motivam, distorcem, disciplinam ou orientam o comportamento humano, refletindo especialmente a respeito da essência das normas, valores, prescrições e exortações presentes em qualquer realidade social. 2. conjunto de regras e preceitos de ordem valorativa e moral de um indivíduo, de um grupo social ou de uma sociedade.

${ }^{8}$ Antropologia, Sociologia, História, Ciências Políticas e Sociais, Filosofia.
} 
(1995), Antonio Candido (1970), Raymundo Faoro (1976), Roberto Schwarz (1997). Em relação ao discurso fundador, sobre a formação do país e a construção da identidade nacional, Eni P. Orlandi $(2003,2008)$ foi uma das referências, juntamente com Marilena Chauí (2000). Alguns estudos particulares, como a Fenomenologia do brasileiro, do filósofo Vílem Flusser (1998), ou Brasil para principiantes, de Peter Kelleman (1964), apresentaram contribuições relativas ao olhar estrangeiro sobre o brasileiro. Quanto ao tema de estudo desta pesquisa - "jeitinho" brasileiro - as principais fontes investigadas foram Roberto DaMatta (1983, 1986, 2004), Lívia Barbosa (2006), Alberto Carlos Almeida (2007), Lourenço Stelio Rega (2000), Fernanda Borges (2006), Venceslau Alves de Souza (2008), entre outros.

Um novo panorama foi-se configurando conforme a pesquisa sobre o tema avançava. O sentimento de preconceito foi-se dissipando, abrindo espaço para uma visão mais ampla do que é ser "brasileiro".

O brasileiro é o resultado da miscigenação do branco, negro e índio de Gilberto Freyre. É aquele que desenvolve um "racismo à brasileira", o preconceito de ter preconceito, nas palavras de Florestan Fernandes ${ }^{9}$. É o "homem cordial", hoje tão criticado, de Sérgio Buarque de Holanda, com sua afabilidade, candura e singeleza, hospitalidade, generosidade, expressões de um caráter emotivo. É o povo do país da Copa de 2014 e das filas intermináveis nos hospitais da rede pública. Dos que vivem atrás de fortalezas e dos que estão expostos à violência urbana. São homens e mulheres do frevo, do samba, da bossa-nova, da Tropicália, dos Mutantes, dos festivais, da MPB, dos sertanejos, do forró, do funk. Do brega e do chique. Dos que "agregam" e dos "diferenciados". É o povo que no carnaval subverte a ordem, transveste-se do que quiser. Do Brasil do "ame-o ou deixe-o" e do "abaixo a ditadura"! Daquele que aceita que tudo "acabe em pizza", dos "caras-pintadas" e de ambos. É aquele que defende os animais de maus-tratos e que pratica o tráfico de animais silvestres. É aquele que reclama dos efeitos das enchentes, mas lança lixo nos córregos e bueiros. É o povo do sincretismo religioso. Aquele que é pessimista e não vê perspectiva para o futuro do país, e o que sempre enxerga grandes possibilidades à frente. Faz parte daqueles que fazem campanhas pela responsabilidade ao volante, e dos tantos outros que se recusam ao teste do

\footnotetext{
${ }^{9}$ In Roberto DaMatta (2004, p. 25).
} 
bafômetro. Da feijoada, da comida baiana, do acarajé, da cozinha mineira, do pão de queijo, do frango caipira, da mistura do arroz com feijão, do churrasco e da caipirinha. Dos que dão um "jeitinho". Enfim, o brasileiro pode ser tudo o que se diz dele.

Roberto DaMatta (1986), quando busca esclarecer como se constrói uma identidade nacional, pondera entre outras coisas, o que faz com que um indivíduo seja brasileiro ou americano. Após somar os traços apresentados, pode-se dizer quem o brasileiro é, em contraste com o americano. Dessa forma o autor apresenta sua descoberta:

\begin{abstract}
É certo que inventei um "brasileiro" e um "americano" que o acompanhava por contraste linhas atrás, mas quem me garante que aquilo que disse é convincente para definir um brasileiro foi a própria sociedade brasileira. $\mathrm{Ou}$ seja: quando eu defini o "brasileiro" como sendo amante do futebol, da música popular, do carnaval, da comida misturada, dos amigos e dos parentes, dos santos e dos orixás etc., usei uma fórmula que me foi fornecida pelo Brasil. O que faz um ser humano realizar-se concretamente como brasileiro é a sua disponibilidade de ser assim (DAMATTA, 1986, p.18).
\end{abstract}

O contraste apresentado por DaMatta também é abordado por Caetano Veloso em Americanos $^{10}$, música de sua autoria, na qual se ouve: "...Para os americanos branco é branco, preto é preto/ (e a mulata não é a tal) ..." Tal alusão corrobora com a ideia de que uma das diferenças básicas entre brasileiros e americanos é relativa à mistura. Entre nós brasileiros há a valorização da mulata, das nossas tantas Gabrielas, do cheiro do cravo e da cor da canela. Lá elas nem existem ou são alvo do mais explícito preconceito.

Não que o preconceito aqui também não exista. Existe e é velado, às escondidas. Segundo o ilustríssimo professor Florestan Fernandes, a democracia racial no Brasil é um mito social, criado pela maioria, tendo em vista interesses sociais e valores morais. Várias são as formas de preconceito racial: o americano é explícito, aberto e sistemático; o brasileiro, dissimulado e assistemático. Assim explica o sociólogo:

Surgiu no Brasil uma espécie de preconceito reativo: o preconceito contra o preconceito de ter preconceito. Ao que parece, entendia-se que ter preconceito seria degradante e o esforço maior passou a ser o de combater

${ }^{10}$ Disponível em: <http://letras.mus.br/caetano-veloso/44777/>. Acesso: 17 nov. 2012. 
a ideia de que existiria preconceito no Brasil, sem se fazer nada no sentido de melhorar a situação do negro e de acabar com as misérias inerentes ao seu destino humano na sociedade brasileira (FERNANDES et al. 20052006, p. 173-174).

Como assinala o professor, a preocupação nunca foi resolver a questão. Para que se alcançasse a apregoada democracia racial, "negros e mulatos precisariam confundir-se com o branco num mundo de igualdade de oportunidades para todos, independentemente da cor da pele e da extração social" (Ibidem, p. 174-175).

E por que no Brasil a mulata desfruta de sucesso? De acordo com o sociólogo Oracy Nogueira (Ibidem, p.178), entre os tipos de preconceito, o do americano é de origem, de ascendência e sangue, que é segregacionista e racista, enquanto que o brasileiro é de marca, com ideologia assimilacionista e miscigenacionista, interessam os seus traços, vale a aparência física, e pode ser contrabalançado com características como elegância, talento, polidez, instrução. No caso da mulata, em geral, o que conta são seus atributos físicos.

Portanto, a comparação entre os modelos de preconceito de americanos e brasileiros deixa a falsa impressão de que no Brasil não há discriminação racial.

O professor João Baptista Borges Pereira, respondendo à pergunta: "Existe preconceito racial no Brasil?", discorre sobre o assunto:

\begin{abstract}
"O preconceito racial é apenas uma modalidade de preconceito. Em sentido amplo, é encontrado em todas as sociedades humanas. O preconceito é expressão do que em antropologia se denomina etnocentrismo". Em seguida, explica que etnocentrismo é a "tendência, ao que tudo indica universal, que leva indivíduos, grupos e povos à supervalorização de suas próprias expressões de vida, conduzindo-as, consequentemente, a subestimar as características de outros indivíduos, grupos e povos. Atrás do preconceito está a imagem estereotipada do outro, do estranho, a exaltar qualidade, a enxergar defeitos" (Ibidem, p. 175).
\end{abstract}

A análise da definição dada pelo professor Pereira, sugere um questionamento: o "jeitinho", tal como é visto pela estrangeiro, não seria também uma forma de preconceito?

Como falar do Brasil, do "jeitinho", de estereótipo, e não falar de futebol?

Enquanto elaboro este texto vivemos às vésperas da Copa do Mundo da FIFA de 2014. Notícias que dão eco a todo tipo de estereótipo sobre o país pululam em todas as mídias. Vale ressaltar que, apesar da relevância do tema, este não é o foco do trabalho, portanto, será brevemente abordado. O Brasil é visto e conhecido como 
o "país do futebol", imagem adquirida após a conquista do primeiro título mundial na Suécia, em 1958, e confirmada após a sucessão de títulos obtidos em 1962, 1970, 1994, 2002. E existe um enorme desejo e torcida pela conquista do hexacampeonato em 2014, com a realização da Copa em solo brasileiro. Há discussões sobre como o fenômeno futebol é tratado, chamado por alguns, ao lado da religião, de "ópio do povo". Waldenir Caldas, sociólogo e professor, autor do artigo O futebol no país do futebol, conta que o brasilianista Robert M. Levine, historiador americano, era partidário da concepção do futebol como "ópio do povo", "que serviria de instrumento para classe dominante manipular as massas como forma de sublimar a miséria e as desventuras da pobreza através do sucesso meteórico da conquista de um campeonato doméstico ou internacional" (LEVINE, apud CALDAS, 1986). O próprio Caldas discorda dessa posição. Para ele, "todo fenômeno social de grande ressonância popular (no Brasil, o carnaval e o futebol) possui importância social e política incontestável. [...] Transformá-las sempre em “ópio do povo", em algo alienante, corresponde a ter uma visão unilateral e maniqueísta dos processos sociais (CALDAS, 1986). A questão é o uso políticoideológico que o Estado faz dessas manifestações, sejam elas de cunho esportivo, artístico ou de outra ordem.

No presente momento, apesar de o discurso dos governos federal, estaduais e municipais reafirmarem a importância da realização da Copa aqui e agora, algumas manifestações populares apontam para uma situação diferente. Uma parte do povo com outras preocupações, ameaçando colocar em risco a realização do evento, questionando tudo que foi feito, como foi feito, e cobrando outras prioridades.

Contudo, quando se ouve o hino oficial ${ }^{11}$ da Copa - de autoria de Alexandre Pires entre outros - interpretado por "gringos", em sua maioria (Santana, Wyclef Jean, Avicii e Alexandre Pires), fazer menção a Dar um jeito (We will find a way) ${ }^{12}$,

\footnotetext{
${ }^{11}$ One Love, One Rhythm - The 2014 FIFA World Cup Official Album apresenta We Are One (Ole Ola) como a canção oficial da Copa do Mundo FIFA 2014 e Dar Um Jeito (We Will Find a Way) como o hino oficial da Copa do Mundo FIFA 2014. Dar um jeito (We Will Find a Way) foi composta por Alexandre Pires, Arash Pournouri, Rami Yacoub, Carl Falk, Tim Berling, Arnon Woolfson, Diogo Vianna e Wyclef Jean. Disponível em <http://pt.wikipedia.org/wiki/One_Love,_One_Rhythm_The_2014_FIFA_World_Cup_Official_Album>. Acesso em: 15 jun. 2014.

${ }^{12}$ Disponível em: <http://www.vagalume.com.br/santana/dar-um-jeito-we-will-find-a-way-feat-wyclefjean-alexandre-pires-avicii.html\#ixzz32ZZk4wlz>. Acesso em: 25 mai. 2014.
} 
traduzido como Nós vamos achar uma solução, surge a pergunta: Vamos achar uma solução para o quê?

Apesar de ser um hino de alcance mundial, as duas primeiras estrofes fazem menção à luta pela sobrevivência e não há como deixar de identificar a alusão desses primeiros versos à situação vivida pela maioria do povo brasileiro. A canção, no trecho que se refere às agruras, está em inglês, sem versão para o português. Entretanto, a letra apresenta uma solução: se você tem fome, mas sente o calor e a vibração, tem força de vontade e fé, acredita no seu sonho, acredita na sua estrela, você vai alcançar o sucesso e a fama. É interessante ressaltar que este trecho, de exaltação do sucesso, é cantado na língua pátria.

O sujeito da canção é convidado a crer que alcançar sucesso e fama depende unicamente de sua atuação No entanto, Bauman discorre que o processo de individualização é uma fatalidade, e não uma escolha; e a autossuficiência, uma ilusão. E acrescenta:

Que homens e mulheres não tenham nada a que culpar por suas frustações e problemas não precisa agora significar, não mais que no passado, que possam se proteger contra a frustração utilizando suas próprias estratégias, ou que escapem de seus problemas puxando-se, como o Barão de Munchausen, pelas próprias botas. E, no entanto, se ficam doentes, supõese que foi porque não foram suficientemente decididos e industriosos para seguir seus tratamentos, se ficam desempregados, foi porque não aprenderam a passar por uma entrevista, ou porque são, pura e simplesmente, avessos ao trabalho; se não estão seguros sobre as perspectivas de carreira e se agoniam sobre o futuro, é porque não são suficientemente bons em fazer amigos e influenciar pessoas e deixaram de aprender e dominar, como deveriam, as artes da auto expressão e da impressão que causam. Isto é, em todo caso, o que lhes é dito hoje, e aquilo em que passaram a acreditar, de modo que agora se comportam como se essa fosse a verdade. Como Beck adequada e pungentemente diz, "a maneira como se vive torna-se uma solução biográfica das contradições sistêmicas". Riscos e contradições continuam a ser socialmente produzidos; são apenas o dever e a necessidade de enfrentá-los que estão sendo individualizados (BAUMAN, 2001, p. 43).

Bauman parece alertar para o fato de que as soluções biográficas dos sujeitos, ou ditas de outro modo, soluções individualizadas, reduzem a complexidade do espaço social onde "as contradições da existência individual são coletivamente produzidas" (BAUMAN, 2001, p. 48).

O futebol como fator de inclusão e ascensão social parece fazer parte dessa solução biográfica para a vida de alguns brasileiros, como ilustra o funk, de MC 
Guimê, País do futebol ${ }^{13}$. Nele, repete-se a mesma fórmula do hino da Copa: o menino da favela, que chama a atenção para o lugar em que chegou, que andava descalço, jogando futebol, no campo de barro e poeira, e hoje ganha o asfalto, "de nave do ano", "talento, é arte de chão, ouro de favela", "ontem foi choro, hoje tesouro", "que venceu a desnutrição" "e hoje vai dominar o mundo". É o futebol apresentado como forma de concretizar o sonho, de ter reconhecimento: "por onde a gente passa é show", "olha onde a gente chegou".

No hino da Copa há uma referência - "we're wavin' all our rags" - que em versões livres está sendo traduzido como "estamos balançando nossos lenços". Será que são lenços que as pessoas estão balançando? Porque no contexto de quem não tem o que comer, rags seria mais apropriadamente traduzido como trapos! Teriam a mesma conotação, trapos, lenços e bandeiras? As propostas de hino e música oficial para o evento não estariam abusando do uso de preconceitos ou reforçando estereótipos?

Ainda a propósito do futebol, com a proximidade da Copa do Mundo, o "jeitinho" ganha contornos especiais devido à associação do "modo de ser do brasileiro" com o "futebol-arte" praticado pela seleção canarinho. Paolo Demuru, doutor em Semiótica pela Università de Bologna e pela Universidade de São Paulo, em artigo intitulado Batalha do jeitinho - De como o Brasil e Itália levam a campo a arte de se safar - publicado no caderno Ilustríssima do jornal Folha de São Paulo, em 25 de maio de 2014, discorre sobre o fato de Brasil e Itália apresentarem duas filosofias futebolísticas e existenciais, ao mesmo tempo opostas e convergentes. $O$ autor explica porque o estilo de jogo adotado pela Itália nos anos cinquenta, 0 "catenaccio" - cadeadaço, ou uma forte tranca - era justificado pelo tipo físico, associado aos "preceitos da índole e às virtudes da especificidade cultural", o que, no caso dos jogadores italianos, "significava apostar tudo na manha e na esperteza". Segundo o autor, graças às narrações de um certo jornalista esportivo,

o "catenaccio" se firmou, na segunda metade do século 20 , como a mais perfeita tradução do "jeitinho italiano": a tal "arte di arrangiarsi", "a arte de se virar", um estilo de vida enraizado na lógica do "sem frescura e direto no ponto", emblema, para muitos, da capacidade inata dos italianos de obter

\footnotetext{
${ }^{13}$ Disponível em: <http://musica.com.br/artistas/mc-guime/m/pais-do-futebol-part-emicida/letra.html>. Acesso em: 26 mai. 2014.
} 
sempre o melhor resultado possível diante das intempéries, (sic) dos eventos e das ruínas da história (DEMURU, 2014).

O autor ainda relembra a final da Copa de 1970, na cidade do México, em que Brasil e Itália se enfrentam e o Brasil sai vencedor pelo placar de $4 \times 1$, derrota atribuída ao fato de a seleção italiana ter renegado o "catenaccio". A vitória brasileira é associada ao "futebol-arte", "típico, como todos sabem e contam, do modo de ser brasileiro". Ambos, o "catenaccio" e o "futebol-arte", são utilizados para visualizar as formas de vida que se apresentam como similares, tendo a astúcia como ponto forte, na arte de "arrangiarsi" e na arte da malandragem. A diferença na forma de astúcia, diz o autor, é que "a italiana é racional e focada no intelecto", e "a brasileira é instintiva e centrada no corpo". Demuru pontua ainda que Pier Paolo Pasolini teria estabelecido uma formulação dizendo que "os italianos jogam (e vivem) 'em prosa' e os brasileiros jogam (e vivem) 'em poesia"'.

O nosso "jeitinho" pode ser até associado à poesia, mas as razões de se recorrer a ele, na maioria das vezes, nada têm de poético.

O "jeitinho" é uma forma de alcançar um objetivo, que em algum momento, e por motivos alheios à vontade dos sujeitos, foi-Ihes negado, seja ele o recurso para a solução de uma questão burocrática ou uma dificuldade de outra ordem.

E é o cotidiano que alimenta as diferentes situações de uso do "jeitinho". Por 'cotidiano' entende-se não apenas o que faz parte do dia-a-dia como também, segundo Houaiss, o que é banal. Ora, se uma situação da qual se depende para solução dos problemas pode ser considerada banal, só resta ao sujeito recorrer a toda, qualquer ou mínima possibilidade de resolução, mesmo que para isso utilize de subterfúgios, ou do "jeitinho". De acordo com DaMatta (1986),

o "jeito" é um modo e um estilo de realizar. Mas que modo é esse? É lógico que ele indica algo importante. É, sobretudo, um modo simpático, desesperado ou humano de relacionar o impessoal com o pessoal; nos casos - ou no caso - de permitir juntar um problema pessoal (atraso, falta de dinheiro, ignorância das leis por falta de divulgação, confusão legal, ambiguidade do texto da lei, má vontade do agente da norma ou do usuário, injustiça da própria lei, feita para uma dada situação, mas aplicada universalmente etc.) com um problema impessoal. Em geral, o jeito é um modo pacífico e até legítimo de resolver tais problemas, provocando essa junção inteiramente casuística da lei com a pessoa que a está utilizando. O processo é simples e até mesmo tocante (DAMATTA, 1986, p. 101). 
Assim, podemos observar que o "jeitinho brasileiro" está disperso em nosso dia-a-dia em inúmeras situações. Aparece como um paliativo, em situação na qual os modelos de resolução falham, a lei se impõe de forma que tira a dignidade das pessoas, e o "jeitinho" surge como uma terceira via. Ou quando um insight, uma ideia, às vezes banal, resolve uma situação que evita problemas ou dispêndios maiores, de energia, monetários e desgastes emocionais. Mas também está presente quando arranjos obscuros são feitos em gabinetes, empresas, escritórios, e inclusive nas relações interpessoais.

Será que o "jeitinho" define o brasileiro?

Quando se fala da construção da identidade brasileira, há certa recorrência de alguns estereótipos. É o que ocorre com o "jeitinho". A partir da aceitação e compartilhamento por parte da sociedade de certos conceitos sobre si própria, teremos a sua adesão pelo efeito da repetição, que é inerente ao clichê ou estereótipo $^{14}$, e a sua consolidação se dá a cada ocorrência de uso. Ferreira (2003) esclarece que “o 'jeitinho' está impregnado na/da memória do brasileiro, como marca registrada constitutiva da identidade", e assim explica "o jeitinho" brasileiro e o efeito de sentido que ele produz:

Com o 'jeitinho', o grau de adesão parece ser maior, há mesmo uma simpática tolerância e uma aceitação consentida para com esse modo de ser que identifica e distingue o brasileiro. Uma leitura que pode ser feita do clichê é a de que ele funciona como um mecanismo compensatório para o brasileiro, frente a tanta adversidade (FERREIRA, 2003, p.77).

O que se fala do brasileiro e o que ele fala de si constrói um lugar de discurso. Essas vozes produzem os sentidos que são incorporados e assimilados. Assim, quando o brasileiro é chamado a falar de si, assume a posição de enunciador e se confere uma posição que legitima o seu dizer. De acordo com Dominique Maingueneau, em relação à noção de ethos, "ele se outorga no discurso uma posição institucional e marca sua relação com um saber" (AMOSSY, 2008, p. 16).

${ }^{14}$ Estereótipo, segundo Houaiss (2009), é esse próprio padrão, geralmente formado de ideias preconcebidas e alimentadas pela falta de conhecimento real sobre o assunto em questão; ideia ou convicção classificatória preconcebida sobre alguém ou algo, resultante de expectativa, hábitos de julgamento ou falsas generalizações; aquilo que é falta de originalidade; banalidade, lugar-comum, modelo, padrão básico. 
Amossy (2008) salienta o papel essencial que o estereótipo desempenha no estabelecimento do ethos:

A ideia prévia que se faz do locutor e a imagem de si que ele constrói em seu discurso não são totalmente singulares. Para serem reconhecidas pelo auditório, para parecerem legítimas, é preciso que sejam assumidas como doxa, isto é, que se indexem em representações partilhadas. É preciso que sejam relacionadas a modelos culturais pregnantes, mesmo se se tratar de modelos contestatórios.

A estereotipagem, lembremos, é a operação que consiste em pensar o real por meio de uma representação cultural preexistente, um esquema coletivo cristalino. Assim, a comunidade avalia e percebe o indivíduo segundo um modelo pré-construído da categoria por ela difundida e no interior da qual ela o classifica. Se se tratar de uma personalidade conhecida, ele será percebido por meio da imagem pública forjada pelas mídias (AMOSSY, 2008, p.125-126).

Roland Barthes, ao retomar os componentes da antiga retórica, define o ethos como "os traços de caráter que o orador deve mostrar ao auditório (pouco importando sua sinceridade) para causar boa impressão: é o seu jeito [...]. O orador enuncia uma informação e ao mesmo tempo diz: sou isto, não sou aquilo" (BARTHES, 1970, p. 315 apud AMOSSY, 2008, p.10)

No que se refere ao "jeitinho", sua adoção remete à construção de certa imagem de si de seu protagonista, seja para estrangeiros ou para outros brasileiros, e participa fortemente do estabelecimento do que é socialmente compartilhado como ethos do povo brasileiro, em uma enunciação enunciada, ou seja, nas marcas da enunciação deixadas no enunciado. Com sua adoção, instaura-se um mecanismo social de produção de sentido caracterizado na evidência e na sistematização de seu uso e de sua aceitação, que o dotam de um grau de credibilidade, o que, por sua vez, reforça a imagem difundida do modo de ser do "brasileiro" 15 .

Segundo Bráulio Tavares, em um artigo na revista Língua Portuguesa, em que aborda as qualidades e os defeitos de ser brasileiro,

\begin{abstract}
As críticas que nos fazem são sempre parecidas, todas sobre coisas que a gente já sabe e, em certa medida, são verdadeiras: o brasileiro é acomodado, não se mobiliza socialmente para protestar, é excessivamente informal e despreza os instrumentos de controle (leis, Constituição, regulamentos, etc.) (TAVARES, 2013, p. 20).
\end{abstract}

\footnotetext{
${ }^{15}$ Evidentemente, ao falar do "brasileiro" refiro-me tão somente à imagem estereotípica amplamente difundida como representativa dos membros do povo brasileiro; não estou de forma alguma assumindo tal estereótipo como representação fidedigna da índole ou ideologia de todas as pessoas de carne e osso dessa nacionalidade. Feita essa ressalva, passo a empregar brasileiro sem aspas, nesse sentido, por simples economia visual.
} 
Quando o autor pontua que as críticas que se fazem aos brasileiros são, em certa medida, verdadeiras, há um reconhecimento de que os defeitos apresentados podem contribuir para reforçar o estereótipo, por exemplo, do brasileiro acomodado, que vê a situação difícil, "mas deixa como está pra ver como é que fica", e informal, às vezes até demais, nas relações sociais, com dificuldades para saber respeitar o espaço das outras pessoas.

$\mathrm{Na}$ mesma revista, o articulista Pereira Junior discorre sobre o uso da expressão "jeitinho brasileiro" em texto postado pela colunista Samantha Pearson, do blog Beyond Brics do jornal britânico Financial Times. No texto, a jornalista trata o "jeitinho" não como traço cultural, mas como "improviso com cara de trapaça, trivial em qualquer país". Apresenta, inclusive, uma versão inglesa à expressão: "little way”. Segundo Pereira Junior, "o jornal classifica 'jeitinho' como o nocivo hábito de driblar regras e convenções de forma criativa (e até ilegal), com o que o brasileiro resolve de problemas prosaicos até a política monetária" (PEREIRA JUNIOR, 2013, p. 19).

Samantha Pearson, no mesmo artigo, chama o ministro da Fazenda do Brasil, Guido Mantega de "profissional do jeitinho", em razão das manobras contábeis que o governo realizou para que o país cumprisse a meta fiscal de 2012.

Questões econômicas à parte, a forma como o jornal classifica o "jeitinho", não leva em conta toda a variação, todas as nuances que o vocábulo carrega em si. Porém, não podemos dizer que esse estereótipo não nos cabe, pois o jeitinho foi criado e assumido por basicamente "um e cada" brasileiro.

Roberto DaMatta uniu-se ao canal de televisão Futura, tradicional na produção de programas educativos, para a criação de uma série chamada "O bom jeitinho brasileiro". Na apresentação inicial do projeto, o antropólogo resume o jeitinho como "uma maneira de contornar a lei". Afirma que os programas mostrarão o outro lado do jeitinho brasileiro: "conhecer pessoas que apesar de suas dificuldades, não se entregam", e que veem no "jeitinho" a forma de superá-las.

Ora, se existe o "bom" "jeitinho brasileiro", que é o outro lado do "jeitinho", há também o "mau". E, portanto, não há que enxergá-lo como preconceito. Quanto à escolha em relação ao estereótipo, Walter Lippmann, em seu clássico Public Opinion, de 1922, afirma: 
$\mathrm{Na}$ maioria das vezes não vemos primeiro e depois definimos, nós definimos primeiro e depois vemos. Na grande confusão que grassa no mundo exterior, escolhemos o que nossa cultura já definiu para nós, e tendemos a perceber o que selecionamos na forma estereotipada para nós pela nossa cultura ${ }^{16}$ (LIPPMANN, 1922, tradução nossa).

O excerto faz referência a uma tendência de que nossas escolhas recaiam sobre o que é estereotipado, ou seja, sobre aquilo que ainda não conhecemos. É o que podemos constatar na leitura que a articulista do FT faz do "jeitinho". Diz respeito a uma leitura corrente dos estrangeiros sobre os brasileiros.

Monte Mór (2008), em artigo que "investiga a relação suplementar entre identidade e alteridade, compreendendo o modo como o brasileiro se representa para si mesmo, é representado pelo estrangeiro e como a imagem do estrangeiro é construída e difundida para o outro" (MONTE MÓR, 2008, p.161), ressalta que, a leitura de notícias brasileiras impressas no estrangeiro, quando menos atenta, pode ser "tangenciada por estereótipos descomprometidos, conforme se observa em olhares de uns países para outros, de culturas para outras, de regiões para outras" (p.170). Para a autora, aquelas notícias são fonte de reflexão sobre a relação entre identidade e alteridade. Nesse sentido, a autora apresenta as contribuições de Hall (2000), que faz uso da concepção lacaniana sobre espelhamento, quando se refere à identidade:

\begin{abstract}
Um sujeito não vê a sua própria imagem por "inteiro", logo poderá ver-se ou imaginar-se por inteiro no espelho do olhar do outro. Dessa maneira, embora o sujeito seja, por natureza, cindido, dividido, inacabado, incompleto, ele assume a sua identidade como se ela estivesse completa, acabada, unificada, conforme o olhar alheio lhe informa, ou conforme a sua imagem se formou (uma fantasia que se constituiu e cristalizou) no espelho do olhar alheio. É possível expandir essa noção de "espelhamento" aos dois sujeitos dessa relação dialética. Aquele que se vê em posição favorável pode ter a sua imagem espelhada e confirmada pelo olhar de quem the confere superioridade; da mesma maneira, o outro que se acredita em desvantagem pode estar reafirmando a sua identidade no espelho dos olhos do outro (HALL, 2000, apud MONTE MÓR, 2008, p. 171-172).
\end{abstract}

Ainda segundo a autora, o raciocínio de Hall sobre o espelhamento poderia ser utilizado como uma imagem invertida para compreender a visão dos jornalistas estrangeiros acerca dos brasileiros. Segundo Hall (2000), por ser um processo em

${ }^{16}$ For the most part we do not first see, and then define, we define first and then see. In the great blooming, buzzing confusion of the outer world we pick out what our culture has already defined for us, and we tend to perceive that which we have picked out in the form stereotyped for us by our culture. 
andamento, o termo mais apropriado seria identificação e não identidade, uma vez que a identidade surge "de uma falta de inteireza que é 'preenchida' a partir do nosso exterior pelas formas pelas quais imaginamos ser vistos por outros" (HALL, 2000, p. 39 apud MONTE MÓR, op. cit., 172). O cenário brasileiro descrito pelos jornais estrangeiros, como afirma Monte Mór, pode não ser a única representação do país, bem como de seu povo. Contudo, "a imagem frequentemente projetada no espelho do outro pode levar à crença de que o reflexo do objeto é o próprio objeto" (MONTE MÓR, op. cit., p.172).

Particularmente, em relação ao "jeitinho", Barbosa assim retrata a questão associada à identidade:

Ao jeitinho brasileiro, contraponho a falta de jogo de cintura do anglo-saxão, a rigidez do alemão, a sovinice do francês etc. [...] Quando nos referimos ao jeitinho brasileiro como um elemento de identificação social, não significa dizer que acreditamos que ele simbolize a totalidade da sociedade brasileira em todas as suas expressões, nem que expresse o comportamento "típico" do brasileiro e, muito menos, que essa forma da ação social possua uma "essência" exclusivamente nossa. Significa, apenas, que em determinados contextos ele sintetiza um conjunto de relações e procedimentos que os brasileiros "percebem" como sendo deles. [...] Ao seu redor, constrói-se uma série de discursos, uns para negá-lo, outros para afirmá-lo, expressando um conjunto de valores significativos dentro de determinados contextos e domínios e que atualizam partes e momentos da sociedade brasileira (BARBOSA, 2006, p. 165-166).

Afinal, é possível afirmar que o "jeitinho" é um dos elementos que compõem a identidade nacional em determinados contextos e domínios da sociedade brasileira, sem contudo, como afirma Barbosa, expressar nosso comportamento típico ou nossa essência.

Sobrepondo-se à ideia de estereótipo e da identidade, o "jeitinho" é a nossa forma de lidar com certas situações, de buscar soluções. Segundo DaMatta,

O jeito é um estilo de navegação social que passa sempre nas entrelinhas desses peremptórios e autoritários "não pode!". Assim, entre o "pode" e o "não pode", escolhemos, de modo chocante e antilógico, mas singularmente brasileiro, a junção do "pode" com o "não pode". Pois bem, é essa junção que produz todos os tipos de "jeitinhos" e arranjos que fazem com que possamos operar um sistema legal que quase sempre nada tem a ver com a realidade social (DAMATTA, 1986, p. 100-101).

Voltemos a Lívia Barbosa. Inspirada pelo modo de investigação iniciado por Roberto DaMatta, a pesquisadora retoma uma antropologia crítica voltada para o 
estudo dos estilos de fazer e lidar com as vicissitudes do cotidiano brasileiro. Aborda o estudo de ideologias e as representações simbólicas que efetivamente motivam e orientam a vida brasileira diária aqui e agora.

$\mathrm{Na}$ investigação do cotidiano, o "jeitinho" é um tema por excelência. E Barbosa assim o define:

O jeitinho é sempre uma forma "especial" de se resolver algum problema ou situação difícil ou proibida; ou uma solução criativa para alguma emergência, seja sob a forma de burla a alguma regra ou norma preestabelecida, seja sob a forma de conciliação, esperteza ou habilidade. Portanto, para que uma determinada situação seja considerada jeito, necessita-se de um acontecimento imprevisto e adverso aos objetivos do indivíduo. Para resolvê-la, é necessário uma maneira especial, isto é, eficiente e rápida, para tratar do "problema". Não serve qualquer estratégia. A que for adotada tem de produzir os resultados desejados a curtíssimo prazo. E mais, a não ser estas qualificações, nenhuma outra se faz necessária para caracterizar o jeito. Não importa que a solução seja definitiva ou não, ideal ou provisória, legal ou ilegal (BARBOSA, 2006, p. 41).

A autora acrescenta que não há uma uniformidade em relação ao que é "jeito": "o que é e o que não é jeito variam bastante" (p. 41). Varia desde situações nas quais é visto como um favor, a outras em que se confunde com a corrupção. Tal gama de possibilidades acarretará na variação do entendimento do discurso do jeitinho como positivo ou negativo.

Essa variação na compreensão do que é "jeito" foi sistematizada por Barbosa (2006), em um eixo horizontal, no qual a disposição das três categorias ficou assim representada:
$(+)$
$(+) /(-)$

$(-)$

favor

jeito

corrupção

A disposição do fato em um determinado ponto do eixo não é exata. Isto porque sua localização no eixo depende da situação e das relações das pessoas envolvidas. Enfim, as nuances do "jeitinho" irão variar, inclusive, em decorrência do 
discurso adotado pelas pessoas envolvidas. As categorias localizadas nas extremidades, apresentam certas características que as tornam, às vezes, passíveis de serem identificadas. Mas nem sempre...

O "favor", frequentemente, implica em reciprocidade. Quem recebe o "favor" fica em posição de devedor. Não que não haja reciprocidade entre quem dá e quem recebe o "jeito", mas ela pode ser de outro tipo: qualquer pessoa pode receber a retribuição de um "jeitinho", fazendo valer a máxima de que "hoje sou eu, mas amanhã pode ser você", então, "uma mão lava a outra". Já a diferenciação entre "corrupção" e "jeitinho", por vezes, não é clara. As pessoas tendem a associar a "corrupção" a um ganho material. Se o ato envolver uma "cerveja", um "cafezinho" ou apenas um "bom papo", passa por "jeitinho". Se uma quantia vultosa de dinheiro estiver em questão, raramente escapa do matiz da corrupção. Todos os aspectos de cada nuance, presentes no eixo, ou seja, a abordagem que será dada a cada situação, dependerá basicamente da postura das pessoas em relação ao "jeito", do discurso por elas assumido: um discurso positivo ou negativo (BARBOSA, 2006).

O discurso positivo é um discurso de aprovação, resultado das experiências do dia a dia das pessoas. Aceita uma amplitude de uso bem vasta, pois é visto como resposta criativa a uma situação de emergência, como forma de agilizar procedimentos, ou porque já o aceitam como elemento universal à disposição das pessoas, e acham certo e conveniente. O "jeitinho" é encarado como um paliativo até que haja uma solução mais eficiente ou definitiva. Normalmente, este discurso não é associado à corrupção. É o "jeitinho" das relações pessoais. Exalta as características atribuídas ao povo brasileiro como simpatia, alegria, esperteza e, por vezes, adquire um tom ufanista. O "jeito" ainda pode ser um fator que humaniza as relações, superando a rigidez, a impessoalidade, levando em conta a condição humana acima de tudo (BARBOSA, 2006).

O discurso negativo, defende a autora, comumente, estabelece como parâmetro o Brasil e os países ditos desenvolvidos. Situações do cotidiano, permeadas pela violência urbana, o desemprego, a precariedade da saúde pública, são recorrentes na fala coloquial de quem adota este discurso. Fala apoiada no saudosismo, e que não ultrapassa a superficialidade das discussões sobre a complexidade dos problemas socioeconômicos do país. Talvez, a partir deste tipo de 
discurso haja a veiculação de um desejo, por parte de alguns grupos, do retorno da ditadura militar. Segundo Barbosa (2006), o discurso teórico negativo sobre o "jeitinho" "é também um discurso de denúncia". E acrescenta:

\begin{abstract}
Denúncia de nossas instituições sociais e políticas carentes de credibilidade e de nossa herança ibérica. Denúncia de nossos homens públicos, da corrupção e da impunidade. No discurso erudito, isso não vem de hoje. $O$ formalismo de nossas leis, a pouca seriedade de nossos dirigentes, a situação catastrófica de nosso povo não são fenômenos recentes. Chegaram com Cabral e aqui ficaram pelas mãos dos portugueses.

Nos países onde ocorreu uma colonização de origem anglo-saxã, as coisas são vistas de forma diferente. As leis, as regras, são percebidas como mais de acordo com a prática social e o povo é mais ordeiro e disciplinado. A ideia predominante aqui é de que nada funciona, as coisas não são sérias e que o casuísmo é a tônica de todos os setores da sociedade (BARBOSA, 2006, p.74-75).
\end{abstract}

Em suma, o "jeitinho" apresenta-se, assim, numa grande multiplicidade de formas, sejam no âmbito da resolução de problemas, das relações pessoais, em situações sociais concretas, e mesmo frente a regras, normas ou leis. Todas as flexibilizações do sujeito para conseguir o objetivo almejado, resultam em um "jeitinho" compreendido ora como algo positivo, criativo, ora como algo negativo, no limiar da ilegalidade. Muitas vezes a distinção entre a caracterização do jeito dependerá do tipo de discurso assumido por quem o aprova, o louva, o valoriza ou por quem o rejeita e desaprova.

A questão que envolve toda essa gama de possibilidades quanto à tipificação do "jeitinho", além da ambiguidade que permeia o fato de estar associado à identidade do povo brasileiro, é abordada por Barbosa (2006) da seguinte forma:

... o jeitinho não só é um mecanismo de ajuste à realidade institucional brasileira, mas também um elemento de identidade social positiva e negativa. Ele é percebido e reconhecido como nos definindo como país e como povo. Portanto longe de ser algo escuso, embaraçoso, o jeitinho é reconhecido, admitido, louvado e condenado (BARBOSA, 2006, p. 32).

Portanto, mesmo reconhecido, louvado ou condenado, é difícil distinguir quando o "jeitinho" é visto como favor ou corrupção. Onde um termina e o outro começa? Qual o efeito de sentido que cada um dos tipos de "jeitinho" produz? Os diferentes "jeitinhos" dialogam entre si? 


\section{Objetivos e justificativa}

Para responder a essas perguntas, o objetivo geral deste trabalho é estudar a amplitude de sentido que o vocábulo "jeitinho" ou a lexia "jeitinho brasileiro" apresentam, as diferentes possibilidades de seu uso e os efeitos de sentido que cada exemplo pode nos mostrar. A partir de textos que ilustram diferentes situações de uso do "jeitinho", como objetivo específico, procurei ampliar o continuum proposto por Barbosa (2006), ao identificar outras possibilidades de uso do "jeitinho" ao longo do eixo horizontal, sobre o qual a autora dispõe favor, jeito e corrupção. Vale ressaltar que a forma como o "jeitinho brasileiro" é recebido e percebido pelo estrangeiro falante de língua inglesa também é foco deste trabalho. Quais as formas de apresentação do jeitinho no contexto de língua estrangeira? É de fácil apreensão? Precisa ser traduzido? É fácil e clara a tradução? E se não traduzido, como se apresenta? Encontrar respostas para tais perguntas constituiu-se também como um dos objetivos específicos da pesquisa.

A partir dos objetivos que orientam este trabalho, considerei importante realizar um estudo de revisão e exploração da produção científica sobre o tema "jeitinho brasileiro", existente em base de dados disponíveis no Brasil. A fonte de pesquisa foi o site da Biblioteca Digital Brasileira de Teses e Dissertações (BDTD) ${ }^{17}$. http://bdtd.ibict.br/a-bdtd.

No banco de dados da Biblioteca Digital Brasileira de Teses e Dissertações, a pesquisa foi iniciada pela procura básica, com o descritor "jeitinho brasileiro". Foram localizados 14 trabalhos identificados com este tema: 9 dissertações de mestrado, 4 de doutorado e 1 sem identificação.

${ }^{17}$ O Instituto Brasileiro de Informação em Ciência e Tecnologia (IBICT) coordena o projeto da Biblioteca Digital Brasileira de Teses e Dissertações (BDTD), que integra os sistemas de informação de teses e dissertações existentes nas instituições de ensino e pesquisa brasileiras, e também estimula o registro e a publicação de teses e dissertações em meio eletrônico. Este projeto - iniciativa inovadora do IBICT, em parceria com as instituições brasileiras de ensino e pesquisa - possibilita que a comunidade brasileira de C\&T publique suas teses e dissertações produzidas no país e no exterior, dando maior visibilidade a produção científica nacional. BDTD foi desenvolvida no âmbito do programa da Biblioteca Digital Brasileira, com apoio da Financiadora de Estudos e Pesquisas (Finep). A BDTD utiliza as tecnologias do Open Archives Initiative (OAl) e adota o modelo baseado em padrões de interoperabilidade consolidado em uma rede distribuída de bibliotecas digitais de teses e dissertações. Nessa rede, as instituições de ensino e pesquisa atuam como provedores de dados e o Ibict opera como agregador, coletando metadados de teses e dissertações dos provedores, fornecendo serviços de informação sobre esses metadados e expondo-os para coleta por outros provedores de serviços, em especial pela Networked Digital Library of Theses and Dissertation (NDLTD). Disponível em: <http://bdtd.ibict.br/>. Acesso em: 12 mai. 2014. 
O período de publicação dos trabalhos não é contínuo. Apresento a tabela abaixo para melhor visualização dos intervalos de produção científica sobre o tema e de suas quantidades respectivas nos anos identificados com publicação.

Tabela 1: Produções científicas com o tema Jeitinho Brasileiro

\begin{tabular}{|c|c|}
\hline Ano de publicação & $\begin{array}{c}\text { Quantidade de } \\
\text { teses/dissertações com o tema } \\
\text { jeitinho brasileiro }\end{array}$ \\
\hline 1997 & 1 \\
\hline 2004 & 1 \\
\hline 2005 & 1 \\
\hline 2006 & 3 \\
\hline 2008 & 2 \\
\hline 2009 & 2 \\
\hline 2010 & 1 \\
\hline 2012 & 1 \\
\hline 2013 & 2 \\
\hline
\end{tabular}

A investigação revelou diversidade de trabalhos. Foi possível observar a ênfase do tema, especificamente, nas áreas de conhecimento das Ciências Sociais (3 trabalhos), da Administração (3 trabalhos) e da Saúde (2 trabalhos). Outras áreas de conhecimento como Comunicação e Semiótica, Ciências Econômicas, Direito, História Social e Design/Arquitetura destacaram-se com um trabalho cada.

Embora a pesquisa realizada com o descritor "jeitinho brasileiro" tenha resultado nas 14 teses/dissertações referidas acima, o "jeitinho brasileiro" aparece como assunto em apenas 5 delas. Nos demais trabalhos, o descritor aparece, especificamente, no resumo dos trabalhos. Entretanto, os termos isolados "jeitinho" e "jeito" também parecem ser utilizados como sinônimos para o descritor "jeitinho brasileiro", uma vez que aparecem como temas nos resumos dos trabalhos referidos.

Assim, é importante ressaltar que a escolha correta dos descritores e/ou palavras-chave é aspecto relevante no processo de escrita de um trabalho, bem como no processo de investigação científica, uma vez que pode dificultar na localização de informações relevantes para o pesquisador.

Diante do número pequeno de referências encontradas a partir da combinação dos termos, o descritor "jeitinho" foi utilizado de forma isolada, para 
ampliar a busca de trabalhos. Com este descritor, foram localizados 17 trabalhos, 3 a mais dos 14 encontrados inicialmente: duas dissertações de mestrado e uma tese, em três diferentes áreas de conhecimento - Psicologia Social, Letras e Saúde. Com relação ao ano de publicação, um trabalho é defendido em 2009 e dois em 2014.

Nessa investigação, como relatado acima, o "jeitinho" apareceu como objeto de estudo na área de Letras, especificamente em dois trabalhos. O primeiro deles é a tese de doutorado de Fernanda Borges, em Comunicação e Semiótica, $O$ jeito do corpo e o jeitinho brasileiro, de 2005, pela PUC/SP. A tese é o resultado de um estudo interdisciplinar, pois Borges se utiliza de sua formação em filosofia, seu mestrado em ciências da motricidade, ligado à biologia e à educação física. Segundo a autora, "uma maior aproximação com as ciências cognitivas e os estudos culturais favoreceu o desenvolvimento das aproximações entre o jeito do corpo e o jeitinho brasileiro". O segundo trabalho é a tese de doutorado de Carolina Scali Abritta, Construção do acordo em relações de consumo: um estudo de audiências de conciliação, defendida em 2011, no Departamento de Letras, da PUC/RJ. Neste trabalho o objetivo geral foi examinar as categorias analíticas - modos de apresentação do self, faces atribuídas e papéis construídos - e identificar como essas categorias mostravam-se relevantes para a realização do acordo. O "jeitinho" apareceu como uma estratégia para garantir o acordo e o exercício do direito.

Um trabalho, porém, não apareceu neste estudo exploratório, mas mereceu atenção pela área do conhecimento em que está contido. Trata-se da dissertação de Larissa C. F. Muniz, A configuração do jeitinho brasileiro em narrativas literárias, de 2009, defendida no programa de Pós-Graduação em Letras, da Universidade de Santa Cruz do Sul UNISC. A partir da análise de seis obras ficcionais da literatura brasileira, Muniz procura mostrar a ocorrência da instituição do jeitinho, ao longo dos anos.

Desse modo, os objetivos inicialmente apresentados, motivados por interesse e inquietação pessoal, viram-se reforçados pela constatação da ausência de trabalhos acadêmicos sobre o fenômeno, pelo ângulo de sua significação e de seus efeitos de sentido. 


\title{
Método e corpus
}

Em relação à metodologia, esta pesquisa propõe um estudo sobre o "jeitinho brasileiro" sob a perspectiva da semiótica discursiva francesa, desenvolvida por Algirdas Julien Greimas e pela Escola de Paris. Utilizo a teoria geral do sentido, elaborada por Greimas, como metodologia de análise de discursos e textos, pois, segundo Barros (2010), a semiótica tem "o texto, e não a palavra ou a frase, como seu objeto e procura explicar os sentidos do texto, isto é, o que o texto diz, e também, ou sobretudo, os mecanismos e procedimentos que constroem os seus sentidos" (BARROS, 2010, p. 187).

Através dessa teoria busca-se explicar os sentidos do texto e isto se dá pelo exame de seu plano de conteúdo. O plano de conteúdo é concebido sob a forma de um percurso gerativo do sentido, que vai do mais simples e abstrato ao mais complexo e concreto. Neste percurso são estabelecidas três etapas: o nível fundamental, em que ocorre o surgimento da significação como uma oposição semântica mínima; o nível narrativo, no qual a narrativa é organizada sob o ponto de vista de um sujeito; o nível discursivo, em que a narrativa é assumida pelo sujeito da enunciação e se reveste de concretude, em forma de pessoa, espaço e tempo.

Uma variedade de textos compõe o corpus da pesquisa e o predomínio do estudo de casos recai sobre o material literário. A semiótica se apresenta como uma teoria capaz de atingir um leque amplo de objetos: canção, crônica, palestra, artigo jornalístico, entre outros. Porém, é importante salientar que, conforme apontam Lopes e Hernandes (2009),

\begin{abstract}
A variedade de campos abordados poderia fazer supor que é de tudo e de qualquer coisa que a semiótica se ocupa. Não: uma disciplina se define, não apenas pelo objeto, mas também pelo ponto de vista que projeta sobre ele e que é constitutivo do seu desenvolvimento. Todos os campos aqui visitados são objeto de análises que se interessam, antes de mais nada, pelos textos que se oferecem à investigação (LOPES; HERNANDES, 2009, p. 8).
\end{abstract}

No estudo sobre o "jeitinho brasileiro", utilizei diversos textos e, na análise de cada um deles, fiz uso de diferentes níveis do percurso. Esse é um recorte possível, pois segundo Barros (2005) "são estabelecidas três etapas no percurso, podendo cada uma delas ser descrita e explicada por uma gramática autônoma, muito 
embora o sentido do texto dependa da relação entre os níveis" (BARROS, 2005, p. 13).

Para compreender as formas de apresentação do jeitinho no contexto de língua estrangeira foi utilizada a Linguística de Corpus (LC). Ela se apresenta como uma das áreas de pesquisa da linguagem e "ocupa-se da coleta e da exploração de corpora, ou conjunto de dados linguísticos textuais coletados criteriosamente, com o propósito de servirem para a pesquisa de uma língua ou variedade linguística" (SARDINHA, 2004, p. 3). Neste trabalho, a LC atendeu à necessidade de investigar as colocações - "a associação entre itens lexicais, ou entre o léxico e campos semânticos" (Ibidem) - e como as sugestões de léxico apresentadas para a tradução para o inglês se elas se confirmavam. A utilização recaiu sobre o COCA - Corpus of Contemporary American English - o maior corpus da língua inglesa online disponível gratuitamente a pesquisadores. Ligado à Brigham Young University, criado por Mark Davies, o COCA conta com o registro de 450 milhões de palavras, coletadas de 1990 a 2012.

A constituição do corpus do trabalho não foi definida preliminarmente. Os casos foram sendo definidos no decorrer do estudo do tema, a partir da leitura de textos de diferentes áreas de conhecimento, gêneros e suportes.

No processo de busca dos casos que compõem o corpus, localizei textos que relatavam, de forma explícita ou não, o "jeitinho" em suas mais variadas leituras. Ou seja, mesmo que nos textos a visualização do que é comumente nomeado como "jeitinho" não estivesse evidente, busquei as diferentes possibilidades de leitura, para além do que é entendido pelo senso comum ou numa primeira leitura.

Os textos que compõem o corpus desta pesquisa foram subdivididos em três grupos: literários, históricos e periódicos.

Defino os casos literários, a partir de Candido (1972), como as escritas ou criações de toque poético, ficcional ou dramático ${ }^{18}$. Neste trabalho, a crônica Moça

\footnotetext{
${ }^{18}$ Diante da dificuldade em delimitar o que pode ou não ser considerado literatura, julguei importante buscar referência nos estudos de Antônio Candido. Segundo o autor, "a literatura propriamente dita é uma das modalidades que funcionam como resposta a essa necessidade [ficcional] universal, cujas formas mais humildes e espontâneas de satisfação talvez sejam coisas como a anedota, a adivinha, o trocadilho, o rifão. Em nível complexo surgem as narrativas populares, os cantos folclóricos, as lendas, os mitos. No nosso ciclo de civilização, tudo isso culminou de certo modo nas formas impressas, divulgadas pelo livro, o folheto, o jornal, a revista: o poema, conto, romance, narrativa romanceada" (CANDIDO, 1972, p. 83).
} 
deitada na grama (1987), de Carlos Drummond de Andrade, e o conto $A$ carteira (1884), de Machado de Assis, compõem o corpus de textos oriundos da literatura. Do cancioneiro popular, resgato Antonico (1950), de Ismael Silva, e Abrigo de vagabundos (1959), de Adoniran Barbosa. Utilizo ainda uma canção de uma jovem catarinense, Juliana Eleutério, Jeitinho Brasileiro (2009).

Candido (1995, p. 243), ao afirmar que "cada sociedade cria as suas manifestações ficcionais, poéticas e dramáticas de acordo com seus impulsos, as suas crenças, os seus sentimentos, as suas normas, a fim de fortalecer em cada um a presença e atuação deles" ajuda a compreender a importância da seleção de casos da literatura no corpus da pesquisa, uma vez que valores combatidos ou defendidos pelas sociedades são veiculados sob diversas formas literárias. Assim, ao estudar o jeitinho brasileiro como uma prática social/cultural, pode-se tomá-lo como uma prática que pode ser confirmada, negada e combatida em tais manifestações ficcionais.

Quanto aos casos históricos, poderia defini-los como as escritas verídicas, em oposição às escritas ficcionais. Entretanto, a distinção entre ficção e verdade parece ser questionável, como aponta Eagleton (2007), em uma das tentativas de definir o que é literatura, em seu livro Teoria da Literatura: uma introdução. O autor afirma não ser útil a oposição estabelecida entre verdade "histórica" e verdade "artística". Isto porque a literatura também inclui uma escrita fatual ${ }^{19}$.

Assim, considerei importante definir os casos históricos como todos os materiais, sejam fontes ou documentos que ajudam o pesquisador a reconstruir um recorte da "realidade", ou seja, um fato histórico. Mais uma vez, este pode ser um campo de difícil delimitação, principalmente porque há os periódicos (imprensa), que também podem fazer parte desta categoria, uma vez que são ricos materiais para a compreensão da História do tempo presente ou da chamada "história imediata".

Entretanto, como apontam alguns historiadores (ARIES, 1989; RIOUX, 1999), com este tipo de material (jornais, revistas), é necessário o distanciamento crítico do

\footnotetext{
${ }^{19}$ Ainda, segundo autor, "no inglês de fins do séc. XVI e princípios do séc. XVII, a palavra 'novel' foi usada, ao que parece, tanto para os acontecimentos reais quanto para os fictícios, sendo que até mesmo as notícias de jornal dificilmente poderiam ser consideradas fatuais. Os romances e as notícias não eram claramente fatuais, nem claramente fictícios, a distinção que fazemos entre estas categorias simplesmente não era aplicada" (EAGLETON, 2007, p. 1-2).
} 
investigador em relação ao objeto de estudo. Ou seja, o tempo do objeto investigado e o tempo do sujeito investigador devem ser distintos: o passado do objeto deve ser recuperado a partir do presente do pesquisador.

Neste sentido, parece ficar mais clara a constituição dos casos históricos neste estudo que apresenta um único texto analisado. Esse texto é um excerto do subcapítulo Introdução à teoria do 'jeito' do livro Interpretação da realidade brasileira (1973), de João Camilo de Oliveira Torres.

Em relação aos casos de periódicos, oriundos da mídia eletrônica/digital e audiovisual, também foram tomadas como corpus deste trabalho, uma vez que desempenham um papel importante na veiculação de conhecimentos, opiniões, discursos e práticas culturais. A natureza condensada e fugaz dos periódicos é sensível à conjuntura, o que torna tais veículos mais ágeis na propagação dos valores culturais, como o "jeitinho". Assim, casos com registros em periódicos, como reportagens e notícias de jornais e revistas eletrônicas, blogs e sites diversos, são utilizados como fonte de estudo.

Neste grupo, selecionei casos relatados na imprensa, como a reportagem jornalística, Jeitinho só não basta (2008), de Clóvis Rossi; o artigo de revista, O jeitinho que virou 'little way' (2013), de Luiz Carlos Pereira Júnior, e a palestra, realizada por Mário Sérgio Cortella (2008), sobre produtividade, divulgada em blog.

Em relação ao recorte temporal da pesquisa, os textos analisados foram escritos e publicados, originalmente, em um período que compreende o final do século XIX e o século XX.

Na sua proposta de traçar uma história do "jeitinho", Barbosa (2006) declara que "tentar fazer uma história do jeitinho mostrou-se tarefa quase impossível" (BARBOSA, 2006, p. 178). A autora apresenta uma pesquisa na qual fez um levantamento do que já fora escrito em português, estabelecendo certos parâmetros. Utilizou o ano de 1940 como período limite para busca de referência, e encontrou registro escrito com o tema em 1943, na obra de Lysias Rodrigues, Roteiro do Tocantins. Em relação à tradição oral, segundo a autora, também foi problemático. A entrevista com um grupo de pessoas revelou a dificuldade dos entrevistados em identificar nas suas experiências vividas, situações de uso do "jeitinho", pois, as 
referências passadas confundiam-se com a representação do "jeitinho" dos dias de hoje.

É importante considerar que o contexto histórico da produção dos diferentes textos acima descritos, bem como daqueles que analiso neste trabalho, revelam diferentes cenários e personagens, que auxiliam na compreensão do "jeitinho".

$\mathrm{Na}$ literatura, a presença de personagens como Leonardo, de Memórias de um sargento de milícias (1852), de Manuel Antônio de Almeida, e Macunaíma, do livro homônimo (1928), de Mário de Andrade, possibilitam a associação entre o "jeitinho" e o malandro ${ }^{20}$. De acordo com Barbosa (2006), esses personagens vivem "basicamente de pregar peças nos outros, de sair-se bem de situações em que tinham tudo para se dar mal, transformando suas desvantagens em trunfos que foram bem manipulados pela criatividade e improvisação, das técnicas mais usadas pelos usuários do jeitinho" (BARBOSA, 2006, p. 58). A malandragem atravessa os morros cariocas no início do século XX e é constituída por "uns bonitinhas que enrolavam as gringas e os espertos que punham as otárias para trabalhar e sempre conseguiam um troco no baralho", segundo Moreira da Silva ${ }^{21}$ - considerado um dos últimos malandros (SILVA, 1984, apud BARBOSA, 2006, p.58).

Roberto DaMatta acrescenta que a malandragem seria uma variante do "jeitinho", "constituindo-se como uma outra forma de navegação social. O malandro, portanto, seria um agente profissional do 'jeitinho' e da arte de sobreviver nas situações mais difíceis: aquelas nas quais ele está claramente fora ou longe da lei" (DAMATTA, 2004, p.51).

Se, ao final do século XIX, o malandro primava pelas traquinagens, por pregar pequenas peças, no início do século $X X$, ele é visto como agente profissional do “jeitinho", e passa a sobreviver de pequenos expedientes e pequenos golpes. Da metade ao final do século passado, por vezes, é associado ao banditismo, como comparou Morengueira, em declaração à revista Isto É, em 1984 (apud BARBOSA, 2006, p.58).

\footnotetext{
${ }^{20}$ Muniz, L. C. F. A configuração do jeitinho brasileiro em narrativas literárias. Dissertação de mestrado. UNISC, 2009.

${ }^{21}$ Moreira da Silva, o Morengueira, cantor e compositor carioca, (1902-2000), criador do samba-debreque, é considerado o protótipo do malandro carioca, apesar de sempre ter conciliado o trabalho com a carreira de cantor (Júlio Cesar de Barros. Dez anos sem Morengueira, Veja, Blog Passarela, 06 jun. 2010). Disponível em: <http://veja.abril.com.br/blog/passarela/figuracas/moreira-da-silva/>. Acesso em: 9 jun. 2014.
} 
Essa transformação na forma como se lê o personagem malandro, no contexto do "jeitinho", compreende, necessariamente, as transformações espaçotemporais. Os primeiros a desfilarem no cenário foram os traquinas e espertos; seguidos pelo herói sem-caráter e pelo malandro do morro carioca, de calça branca e camisa listrada, explorador de mulheres, bon vivant, que sobrevivia de pequenos golpes. Ainda passaram o malandro dos grandes golpes, e aquele do colarinho branco, de terno e gravata, que jamais pensaria em se colocar tal rótulo.

Entretanto, como afirma Souza (2008), apesar de ser um de seus fundamentos, o "jeitinho" não pode se confundir com a malandragem.

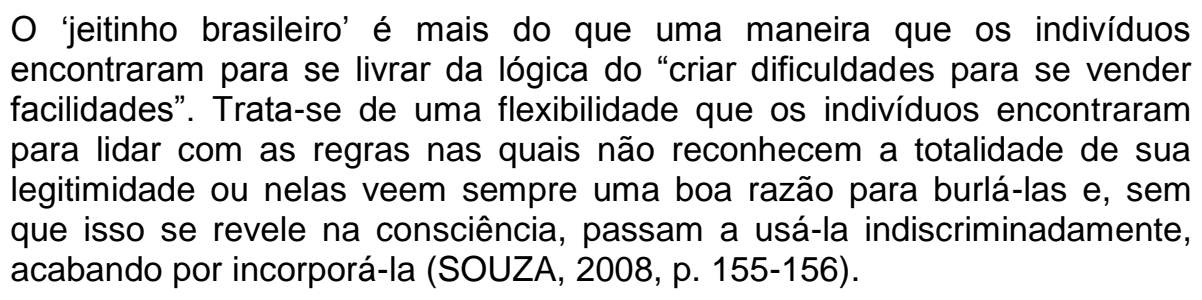

Próximo ao discurso negativo do "jeitinho", o autor parece incluir na passarela todo e qualquer indivíduo, como um advogado, um catador de papelão, uma donade-casa, um empresário, um professor. Para tanto, tais indivíduos devem partilhar da mesma crença ideológica do "quem pode mais, chora menos".

Por outro lado, na contramão do discurso negativo sobre o "jeitinho", Borges (2006), convidaria para esse desfile o operário do chão de fábrica, o garçom, a Moça deitada na grama, os soldados expedicionários, entre outros. Para a autora, o "jeitinho brasileiro" tanto pode desconsiderar normas para criar novas habilidades, quanto envolver solidariedade.

Este trabalho, portanto, propõe explorar e investigar a gama imensa de sentidos associados ao "jeitinho brasileiro" lançando-Ihe um outro olhar, o da semiótica discursiva francesa. Nessa sucessão de personagens e textos, busco identificar as diferentes possibilidades de uso do "jeitinho" e os efeitos de sentido que cada uma dessas possibilidades pode criar.

O trabalho está organizado em dois capítulos, além desta Introdução. O primeiro inicia-se pelo estudo lexical do vocábulo "jeitinho" e das diversas formas correlatas. Além disso, para ilustrar definições e exemplos, faço uso de letras de canções que possibilitaram o estabelecimento de comparação entre os diversos 
tipos de "jeito". O segundo capítulo é dedicado à apresentação e análise de textos que compõem o corpus desta pesquisa. $O$ estudo de oito casos procurou delimitar possibilidades de aproximação das situações de "jeito", localizadas entre o favor e a corrupção, no continuum proposto por Barbosa (2006).

Finalmente, nas Considerações Finais, busco reiterar a importância da discussão sobre o tema do "jeitinho brasileiro", e a necessidade de dissipar a aura negativa que paira sobre ele. Neste trabalho, proponho que um dos tópicos principais para o debate seja a diminuição da elasticidade semântica da lexia "jeitinho", designando para as diversas situações do seu uso, expressões específicas. Portanto, fazer um favor não é "dar um jeito"; subornar um agente da lei não é "dar um jeito"; "achado não é roubado", também não é "jeitinho brasileiro". O brasileiro tem, sim, habilidade, flexibilidade, criatividade, simpatia, caráter solidário e também "jeitinho". 


\section{O QUE É O “JEITINHO”}

Este capítulo contempla uma investigação mais acurada sobre o "jeitinho", por ser o tema principal do trabalho de pesquisa.

Como uma das primeiras etapas do processo de investigação, discorro sobre o assunto, embasada em estudos em dicionários, tendo por objetivo ampliar os significados das palavras, na busca das acepções e locuções que cercam o vocábulo, identificando pontos em comum e as eventuais divergências quanto aos seus conteúdos.

Com o intuito de enfatizar e ilustrar as definições e exemplos, recorro ao uso de letras de canções. O uso das canções possibilitou o estabelecimento de comparações entre os diversos tipos de "jeito", "jeitinho" e "jeitinho brasileiro". A fim de abordar outras formas de "jeitinho", que não são somente as que apresentassem a mesma raiz, ampliei a busca para os vocábulos que definem, por exemplo, o "jeito criativo" como flexibilidade, habilidade, improvisação. Favor e corrupção, tidos como os limites opostos em um eixo horizontal sobre o qual se poderia dispor as diversas nuances de "jeito", foram também contemplados.

\subsection{Introdução ao Estudo Lexical}

Para dar conta das diversas possibilidades que se afiguram como "jeito" ou como "jeitinho", partiu-se para um levantamento das ocorrências e das diversas formas correlatas, pois, algumas vezes, tais vocábulos se apresentam sob a forma de locuções.

O estudo lexical do vocábulo, assim como de seus parassinônimos e locuções é de vital importância perante a escolha metodológica do estudo proposto, a semiótica discursiva francesa. Sendo a semiótica discursiva francesa uma teoria que tem como foco principal o texto, "o que o texto diz e como ele faz para dizer o que diz" (BARROS, 2005, p. 11), a análise das acepções permite que se abra um espectro das possibilidades de leitura que as diversas definições oferecem.

A partir desse levantamento é que desenvolvo o estudo que resultou nas diferentes leituras de "jeitinho". 
Os dicionários consultados foram selecionados principalmente pelos critérios de tradição e confiabilidade. Dicionários tradicionais ${ }^{22}$ como o Dicionário Houaiss da Língua Portuguesa (2001), o Caldas Aulete Dicionário Contemporâneo da língua portuguesa (1987), - ambos nas versões impressa e eletrônica ou digital - o Houaiss eletrônico (2009), e o Aulete digital, contam com diversos bancos de dados que Ihes dão o respaldo necessário a uma obra confiável e completa, e são construídos por meio de critérios rígidos e baseados em estudos computacionais da ocorrência das palavras. O Novo Dicionário Aurélio da Língua Portuguesa (2009) e o Michaelis Moderno Dicionário da Língua Portuguesa (1986), além do uso para busca de palavras, em suas versões online, foram utilizados para consultas das novas regras ortográficas. Para o estudo da etimologia, com a busca da origem da palavra, utilizei o Dicionário etimológico da língua portuguesa (2010), de Antônio Geraldo da Cunha.

Utilizei também alguns outros dicionários online, pela facilidade de acesso e por haver uma grande disponibilidade de títulos. O que contribuiu de certa forma para a decisão em relação ao uso desses dicionários foi o fato de ser o "jeitinho" um vocábulo de uso muito geral e ligado ao dia-a-dia das pessoas. Assim, talvez, pudesse me deparar com acepções inusitadas. Foram eles: Dicio $^{23}$, Dicionário online de português; o Dicionário Priberam ${ }^{24}$ da Língua Portuguesa, o DPLP; Infopédia ${ }^{25}$, Dicionário da língua portuguesa da editora portuguesa, Porto; Léxico ${ }^{26}$, Dicionário de Língua portuguesa que se utiliza de múltiplas fontes. Tais dicionários foram úteis em situações de uso mais comuns, de acordo com a dinâmica da língua, como, por exemplo, o uso de expressões como "jogo de cintura".

Durante o levantamento lexicográfico, julguei interessante fazer uma associação dos vocábulos e das várias locuções com trechos de canções, tanto com o intuito de ilustrar essa seção da pesquisa - árdua para quem a escreve e a lê quanto para facilitar uma visualização e ampliação dos efeitos de sentido. As exceções foram para as acepções de favor e flexibilidade moral, pela dificuldade em

\footnotetext{
${ }^{22}$ Tomou-se como procedimento a utilização do nome do dicionário pelo qual ele normalmente é conhecido, após a sua apresentação formal. Assim, por exemplo, o Novo Dicionário Aurélio da língua portuguesa será doravante identificado como Aurélio.

${ }^{23}$ Disponível em: <http://www.dicio.com.br/>. Acesso em: 10 nov. 2012.

${ }^{24}$ Disponível em: <http://www.priberam.pt/dlpo/>. Acesso em: 10 nov. 2012.

${ }^{25}$ Disponível em: <http://www.infopedia.pt/lingua-portuguesa/>. Acesso em: 8 nov. 2012.

${ }^{26}$ Disponível em: <http://www.lexico.pt/>. Acesso em: 8 nov. 2012.
} 
encontrar letras de canções nas quais esses vocábulos apresentassem o sentido do “jeitinho". A seguir, discorro sobre o processo.

\subsection{0 "jeito"}

Inicio a pesquisa pelo Etimológico, obra de referência de Antônio Geraldo da Cunha, que registra "jeito", substantivo masculino, como modo, maneira, feição, gesto, habilidade, propensão ${ }^{27}$. Do latim, jactus,-us., que significa lançamento, arremesso, tiro; jacto, jato. Pereira Júnior (2013), editor da revista Língua Portuguesa, menciona a abrangência do vocábulo "jeito", apresentada em edição anterior da revista pelo filósofo Jean Lauand, da USP, e pelo linguista John Robert Schmitz, da Unicamp ${ }^{28}$.

Em consulta ao Aurélio, "jeito" é definido como: modo, maneira; feição, feitio, aspecto; disposição de espírito; índole, caráter; propensão, pendor; habilidade, capacidade; arte; torcedura; arrumação, arranjo. Em uma das entradas, aparece como Bras. Fam. (Brasileirismo Familiar), que seria jeito ou modo de proceder próprio de pessoas bem educadas: boas maneiras, bons modos.

Atendo-me ao resultado obtido nos dois primeiros dicionários consultados, Aurélio e Houaiss, pude observar que houve uma convergência de definições para o termo básico da pesquisa, "jeito": modo, maneira, feição, propensão e habilidade surgem como recorrentes.

Referências à definição primeira, e mais comum, modo, maneira, feição, há particularmente ocorrências em música, como por exemplo, Toda menina baiana ${ }^{29}$, de autoria do cantor e compositor Gilberto Gil, da qual recupero a primeira estrofe.

\begin{abstract}
Toda menina baiana tem Um santo que Deus dá Toda menina baiana tem Encantos que Deus dá Toda menina baiana tem Um jeito ${ }^{30}$ que Deus dá
\end{abstract}

\footnotetext{
${ }^{27}$ Neste trabalho, as acepções transcritas dos dicionários serão identificadas em itálico.

${ }^{28}$ Segundo o editor, os autores afirmam que "'jeito' deriva do verbo jacere - jacio, jacere, jeci, jactum (lançar, arremessar). Jacere integra, diz Lauand, termos como 'projeto' (lançado adiante), 'objeto' ou 'objeção' (o que está adiante) e 'sujeito' (por baixo). Lançar para fora (e, ex) é 'ejetar'; para dentro é 'injetar'. Temos 'rejeição' àquilo que deve ser jogado para fora (abjeto); e o que irrompe no meio é 'interjeição'. Já o que se junta (a um substantivo) é 'adjetivo'” (PEREIRA JÚNIOR, 2013, p. 19-20).

${ }^{29}$ Disponível em: <http://letras.mus.br/gilberto-gil/46249/>. Acesso em: 27 nov. 2012.
} 
Toda menina baiana tem

Defeitos também que Deus dá ...

Nessa canção, Gil constrói versos de louvor à menina baiana: Que tem um jeito que Deus dá. Um jeito todo cheio de modos e maneiras de encantar. E como ela tem um santo e que ainda foi dado por Deus, como questionar seus encantos, pois se até mesmo os seus defeitos foram dados por Ele? Seria um jeito abençoado, repleto de gestos e de habilidades, com seus contrastes, assim como a própria Bahia que também ali é cantada, posteriormente.

Em seguida, ainda no Aurélio, investiguei uma série de locuções. $A$ jeito: de molde; a calhar; convenientemente, oportunamente. Ao jeito de: ao modo de; à maneira de. Com jeito: com habilidade, com perfeição. Dar um jeito a: encontrar uma solução ou saída para (determinada situação). Dar um jeito em: Brasileirismo: fazer com que se comporte convenientemente; submeter à disciplina; consertar, reparar, compor. Daquele jeito: Brasileirismo Familiar: expressão com que se traduzem várias ideias, em geral pejorativa: mal, sem vontade, de modo inconveniente. Desculpar o mau jeito: expressão muitas vezes irônica (usada em geral no imperativo), com que se inicia uma crítica, uma restrição, ou se pede desculpa de incômodo que se vai causar a outrem. Fazer jeito: ser conveniente, útil; convir. Levar jeito para: ter jeito, aptidão, queda para. Sem jeito: acanhado, embaraçado, atado. Ser de jeito: ser possível; dar certo.

A locução daquele jeito, normalmente pejorativa, usada para expressar desaprovação ou reprovação a algo inconveniente, surge na canção de autoria de Luiz Gonzaga e Luiz Ramalho, Daquele jeito ${ }^{31}$, com margem a nova conotação, até mesmo marota ou picante.

\author{
Eu não sabia \\ Que a Maria me amava \\ Eu nunca notei, eu nunca notei \\ Também dizia \\ Que não me apaixonava \\ E me apaixonei, e me apaixonei\} bis \\ Mas hoje eu sei que Maria \\ Tá daquele jeito \\ Quando ela olha pra gente
}

\footnotetext{
30 Para facilitar a localização do vocábulo "jeito" e seus parassinônimos, eles serão identificados em negrito nos versos das canções analisadas.

${ }^{31}$ Disponível em: <http://letras.mus.br/luiz-gonzaga/1561263/>. Acesso em: 27 nov. 2012.
} 


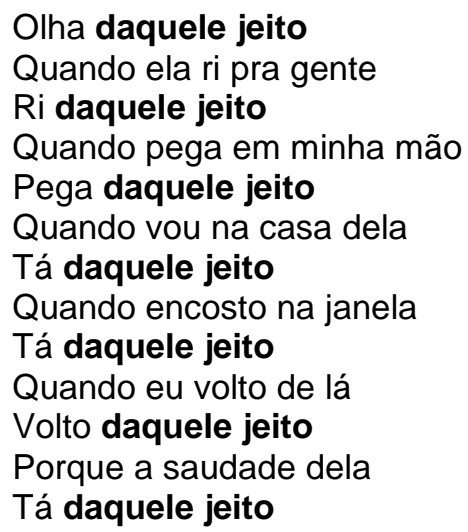

$\mathrm{Na}$ canção, a locução daquele jeito é usada com a intenção de dar margem à dúvida, ao falar de Maria, mas sem explicitar sua maneira de ser ou de agir. Essa é uma das características do rei do baião, que em suas composições faz uso de expressões de duplo sentido e certa malícia.

No Michaelis, "jeito" surge, entre as várias possibilidades, como: arranjo, conveniência; habilidade, aptidão; maneira, modo, forma; gesto.

Assim como no Etimológico, no Aurélio e também no Michaelis, o significado como modo, maneira, é recorrente, o que me permite reiterar que essa é uma acepção importante para definir "jeito".

Em outra ocorrência em letra de música, Um jeito estúpido de $a m a r^{32}$, canção de sucesso na interpretação do ícone da música brasileira, Roberto Carlos, o rei "canta" esse jeito como uma maneira, uma forma particular de amar, um modo estúpido de ser. Tal jeito se apresenta como uma predisposição, uma inclinação ou tendência do sujeito da canção em ser grosseiro, indelicado, pois se mostra como sendo capaz de magoar e ofender. Ele tem consciência desse jeito e o assume.

\footnotetext{
Eu sei

Que eu tenho um jeito

Meio estúpido de ser

E de dizer coisas

Que podem

Magoar e te ofender

Mas cada um

Tem o seu jeito

Todo próprio de amar

E de se defender

Eu tento
}

\footnotetext{
${ }^{32}$ Composição de Isolda e Milton Carlos.

Disponível em: <http://letras.mus.br/roberto-carlos/95655/>. Acesso em: 22 nov. 2012.
} 


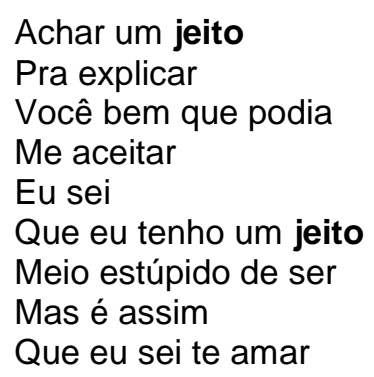

Entretanto, o sujeito, ao mesmo tempo em que busca achar um jeito (de explicar) para ser compreendido, ao expor as razões de sua forma de agir, tenta se justificar, argumentando que esse é o jeito dele (que é outro jeito, uma inclinação) e que cada um tem o seu jeito de amar e de se defender. O sujeito da canção quer fazer a amada aceitar o seu jeito, quer manipulá-la para que ela releve o fato de ele magoá-la e ofendê-la em razão desse seu jeito (não "por ele"). Quer que ela o aceite, numa lógica concessiva, pois, apesar de seu jeito estúpido, ele a ama (e ela bem que poderia, em nome do amor, perdoar o jeito). Assim o faz, talvez numa tentativa de diminuir o sentimento de culpa que carrega, e de valorizar a sua forma 'imperfeita' de amar.

O mesmo Michaelis versão online ${ }^{33}$ apresenta, em acréscimo, "jeito" como: destreza, finura; disposição, propensão; hábito; defeito; torcedura. As locuções são as seguintes: $A$ jeito: em posição conveniente, bem à mão; a propósito, em boa hora. Com jeito: com habilidade; com perfeição. Daquele jeito: gíria: mal. Dar jeito: ser jeitoso. Dar um jeito: fazer o necessário para conseguir uma coisa, para si ou para outrem; arranjar com habilidade; remover com destreza uma dificuldade. De jeito que: de maneira que. Fazer jeito: convir. Mau jeito: movimento desastrado que causa qualquer dor ou luxação; a dor ou luxação assim causada. Não dar jeito: não ser possível; não prestar. Não ver jeito: não ver saída, não ver possibilidade. Sem jeito: desajeitado, desengraçado. Sem jeito para nada: inábil, desastrado. Vir a jeito: calhar.

\footnotetext{
${ }^{33}$ Disponível em: <http://michaelis.uol.com.br/moderno/portugues/index.php?lingua=portuguesportugues\&palavra=jeito $>$. Acesso em: 08 nov. 12.
} 
A propósito da locução com jeito, que é definida como com cautela, prudentemente, pude registrar a marchinha de carnaval de 1956, de autoria de Braguinha Vai com jeito ${ }^{34}$. Ei-la:

\author{
Vai com jeito vai \\ Se não um dia a casa cai (menina) \\ Se alguém te convidar \\ Pra tomar banho em Paquetá \\ Pra piquenique na Barra da Tijuca \\ Ou pra fazer um programa no Joá \\ Menina..
}

A despeito da locução, o conselho que é dado à menina é para que ela aja de maneira cuidadosa, que avalie bem as propostas que receber e a decisão que vai tomar. Alerta para o fato de que a menina pode se dar mal e as coisas se complicarem se, por um acaso, ela não for hábil o suficiente para lidar com a situação como convites para banhos de mar, piqueniques e programas outros. Soa como um conselho de pessoas idosas, experientes: "pense bem, veja lá o que você vai fazer, avalie as consequências".

Outra ocorrência da locução com jeito é na canção Castigo não ${ }^{35}$, de autoria de Toquinho. Na letra, o sujeito, um futuro pai ou mãe ainda bem jovem, é alertado sobre como deve proceder para cuidar e tratar as crianças, como deve educá-las.

\author{
Um dia você crescerá, \\ Será gente grande também. \\ Depois você vai namorar, \\ Gostar muito, muito de alguém. \\ E quando você se casar \\ Virá com certeza um neném. \\ Não deixe nunca \\ Seu filho sozinho, \\ Sem proteção. \\ Castigos não fazem \\ Ninguém mais bonzinho, \\ Não fazem, não. \\ Não levante a voz \\ Nem levante a mão. \\ Não bata, não xingue \\ Nem dê beliscão. \\ Não trate as crianças \\ Como bem entender. \\ Gritos não vão resolver. \\ Criança que apanha
}

\footnotetext{
34 Disponível em: <http://letras.mus.br/marchinhas-de-carnaval/430717/>. Acesso em: 22 nov. 2012.

${ }^{35}$ Disponível em: <http://letras.mus.br/toquinho/87197/>. Acesso em: 01 dez. 2012.
} 
Não aprende a lição.

Com jeito ela vai aprender.

Esse com jeito refere-se ao agir sem recorrer à força, a ações enérgicas. Proceder sem impor sua vontade ou opinião de adulto, que se julga superior, detentor do conhecimento e da sabedoria; sem ofender nem causar constrangimento, mágoa. Definido na canção como contrário às atitudes mencionadas (deixar sozinho, sem proteção, castigos, levantar a voz, bater, xingar, beliscar, gritar), o agir "com jeito" é construído como um atuar com habilidade e perfeição. Com um jeito delicado e seguro, carregado de amor e proteção, carinho e atenção, sem agressões físicas ou verbais, a criança aprenderá.

No Houaiss eletrônico, encontra-se uma grande variedade de acepções. "Jeito" é definido como forma particular; maneira, modo. Aparência externa (de alguém ou algo); feitio, aspecto. Maneira de ser, de atuar, de apresentar-se; caráter, índole. Disposição natural; aptidão, pendor, propensão. Capacidade especial; arte, destreza, habilidade. Torcedura em músculo ou tendão, devida a movimento em falso; torção. Emenda, solução, remédio. Regionalismo: Brasil. Uso: informal: Arranjo, arrumação.

A acepção de jeito como arranjo, registrada anteriormente no Michaelis e agora no Houaiss, surge em canção de Adoniran Barbosa, Despejo na favela ${ }^{36}$. Na letra, verifica-se inclusive um ajeito, que possui a mesma raiz (a- + jeito). Nas entradas que encontrei para ajeitar, Houaiss, de maneira concisa, define: pôr-se a jeito, adaptar-se, acomodar-se. Mais detalhado, Aulete define dessa forma: pôr (algo ou alguém, inclusive si mesmo) em ordem, acomodando ou arrumando; pôr-se a jeito; conseguir se adaptar habilmente a situação nova ou difícil. A locução a jeito, no Michaelis e no Aurélio, sugere em posição conveniente.

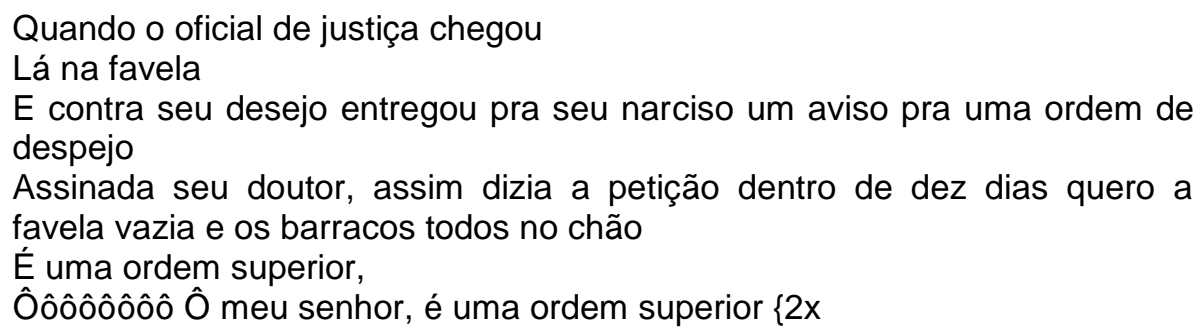

${ }^{36}$ Disponível em: <http://letras.mus.br/adoniran-barbosa/43966/>. Acesso em: 01 dez. 2012. 
Não tem nada não seu doutor, não tem nada não

Amanhã mesmo vou deixar meu barracão

Não tem nada não seu doutor vou sair daqui pra não ouvir o ronco do trator

Pra mim não tem problema em qualquer canto me arrumo de qualquer jeito me ajeito

Depois o que eu tenho é tão pouco minha mudança é tão pequena que cabe no bolso de trás

Mas essa gente ai hein como é que faz???? $\{2 x$

Quando o sujeito diz que em qualquer canto me arrumo de qualquer jeito me ajeito, coloca-se em situação de se adaptar, de se acomodar de modo a contornar uma dificuldade, de buscar a solução para um problema. Situa-se em posição conveniente, atua de maneira a dar um jeito, e toma as providências necessárias. $\mathrm{O}$ dizer do sujeito, que já está acostumado às agruras que envolvem morar em favela, é o de uma pessoa calejada, sozinha, com tão poucas posses que cabem no bolso de trás, provavelmente apenas os documentos. Vai sair logo, pois já sabe que com o ronco do trator vem a demolição. Mas a preocupação do sujeito é com as demais pessoas, com essa gente, famílias, crianças, que não têm para onde ir, pois consigo mesmo não há problema. Tem como dar um jeito, driblar a dificuldade e achar uma forma de superar a situação, seja por meios usuais ou alternativos.

Referindo-me ainda ao Houaiss eletrônico, novamente algumas locuções são acrescentadas às referenciadas anteriormente, pois ampliam as acepções, e somam-se às que não apresentaram ocorrência anterior ou pelo menos não dessa forma. Ao jeito de: ao modo de; como se fosse. Com jeito: com cautela; prudentemente. Mau jeito: expressão que, antecedida de um pedido de desculpas, se usa para aliviar o impacto de uma crítica, feita a seguir, ou de um incômodo que se causou ou se vai causar. Pelo jeito: pelo que as aparências fazem crer. Sem jeito: com embaraço ou acanhamento. Ser de jeito: ser possível.

Uma das locuções que oferece possibilidade de ampliar a pesquisa é sem jeito. Em canção da dupla Aldir Blanc e Cristóvão Bastos, Resposta ao Tempo ${ }^{37}$, pode ser identificada e examinada, mais detalhadamente, em sua primeira estrofe. Eis o trecho:

Batidas na porta da frente

é o tempo

Eu bebo um pouquinho pra ter

Argumento

${ }^{37}$ Disponível em: <http://letras.mus.br/aldir-blanc/440348/>. Acesso em: 22 nov. 2012. 


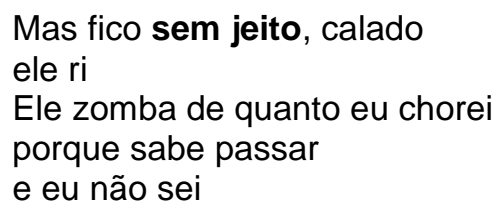

O sujeito que "recebe" o tempo, "que fica sem jeito", está sem graça, pois provoca riso e é alvo de zombaria do seu poderoso oponente. Apesar de ter bebido um pouco para ter argumento, continua calado, fica sem jeito, acanhado. O tempo caçoa da falta de habilidade ou desenvoltura do sujeito para lidar com a situação, com o quanto ele já chorou, e com a sua incapacidade de saber passar. Mas aos poucos, no decorrer da canção, o sujeito tomará rédeas e dará sua Resposta ao Tempo, como o título permite prever.

Dando continuidade ao levantamento lexical, no Aulete digital pode-se ressalvar certa originalidade nas definições. As entradas são mais desenvolvidas. Como tal fato pode enriquecer as análises, novamente recorri ao recorte do que se mostra importante para a ampliação do conhecimento sobre o vocábulo. Assim, "jeito" está registrado como: modo, maneira específica de fazer algo. Aspecto, feição, feitio de alguém ou alguma coisa. Caráter, modo de ser. Único meio, solução. Talento, pendor; vocação. Familiar: Arrumação, arranjo. Movimento ou gesto rápido para comunicar alguma coisa. Solução para algum problema, defeito, etc.

Algumas locuções com acepções diferentes foram registradas. Ei-las: $A$ jeito: a calhar, a propósito. Ao jeito de: de modo semelhante ao de (alguém); com aspecto ou estilo que lembra o de (outra pessoa); em imitação a, ou baseado no modelo ou exemplo de (alguém). Com jeito: sem recorrer à força, a ações enérgicas ou impulsivas; com delicadeza, sem impor sua vontade ou opinião, sem ofender ou causar constrangimento, mágoa. Daquele jeito: Brasileirismo. Familiar: usado para dar ideia de desaprovação ou reprovação; usado para dar ênfase, ideia de intensidade (em tom positivo, negativo ou ambíguo), ao falar do estado de alguém, mas sem descrevê-lo diretamente. Dar um jeito (de/para): contornar uma dificuldade ou solucionar um problema (seja por meios usuais ou alternativos), tomando as providências necessárias. Dar um jeito em: Brasil: fazer alguém comportar-se devidamente, impor disciplina a; por em condição ou estado adequados; consertar, arrumar, ajeitar, reparar, compor. Por vezes, pode trazer conotação de que a 
solução é provisória, paliativa ou improvisada. De jeito a/que: de modo a/que. Desculpe o mau jeito: usado (como fórmula entre educada e irônica) antes de contradizer ou fazer críticas ou objeções a alguém; usado como pedido de desculpa por algum transtorno causado a alguém ou por alguma atitude que poderia ser considerada desrespeitosa. Fazer jeito: ser adequado, útil, conveniente. Levar jeito (para): ter as qualidades físicas ou mentais, habilidade, sensibilidade, etc., para realizar bem certo tipo de atividade. Mau jeito: qualquer ação ou expressão que pode ser incômoda ou ofensiva a alguém, mas sem a intenção de prejudicar ou desrespeitar (geralmente usada ao se pedir desculpa ou ao concedê-la). Pelo jeito: ao que tudo indica, a considerar as circunstâncias. Sem jeito: sem saber como se comportar, ou sem conseguir agir espontaneamente; acanhado, embaraçado, constrangido; sem habilidade ou desenvoltura (para uma atividade, uma tarefa, etc.). Ser de jeito: ser possível, ser plausível. Ter/não ter jeito: ter/não ter solução; ser/não ser passível de correção, melhora; ser/não ser (uma situação) reversível, modificável; ser (uma pessoa) capaz/incapaz de modificar para melhor seu comportamento ou outras características morais ou de personalidade; por vezes usado como forma branda de crítica; restrito, usado geralmente na negativa, e de forma irônica, para manifestar apreço por insistência de alguém em agir de modo gentil etc. Ter jeito (para): levar jeito (para). Tomar jeito: modificar (uma pessoa) seu comportamento para melhor, deixar de insistir em certo tipo de atitude ou abandonar certas opiniões ou convicções; usado por vezes sem conotação pejorativa, ou em tom de crítica amigável etc.

A propósito de ter/não ter jeito, Vai levando ${ }^{38}$, composição de Caetano Veloso e Chico Buarque de Hollanda, dois dos maiores expoentes da música popular brasileira, registram assim essa locução:

\footnotetext{
Mesmo com toda a fama, com toda a Brahma Com toda a cama, com toda a lama

A gente vai levando, a gente vai levando, a gente vai levando

A gente vai levando essa chama

Mesmo com todo o emblema, todo o problema

Todo o sistema, todo Ipanema

A gente vai levando, a gente vai levando, a gente vai levando

A gente vai levando essa gema

Mesmo com o nada feito, com a sala escura
}

38 Disponível em: <http://letras.mus.br/chico-buarque/45183/>. Acesso em: 22 nov. 2012. 
Com um nó no peito, com a cara dura

Não tem mais jeito, a gente não tem cura

Mesmo com o todavia, com todo dia

Com todo ia, todo não ia

A gente vai levando, a gente vai levando, a gente vai levando

A gente vai levando essa guia

Essa composição data de 1975, período da ditadura militar, e apesar de o governo de Ernesto Geisel ter anunciado, naquele ano, o início de uma distensão lenta e gradual, não havia ainda possibilidade de manifestações abertas, fossem elas políticas, sociais culturais ou artísticas.

O país estava ainda sob o manto negro da censura, e os principais autores viam-se cerceados no seu processo criativo. Chico e Caetano fazem parte de um grupo $^{39}$ que consegue burlar o estado instituído. Chico, principalmente, compõe letras repletas de poesia de duplo sentido, criando condições para driblar a censura.

Seria essa uma das brechas que o "jeitinho brasileiro" busca para dar conta das situações difíceis, a maneira hábil de buscar saída? Por exemplo, uma das estratégias utilizadas pelo compositor e seus representantes era a de colocar a letra visada pela censura entre uma série de sandices, camuflando-a. Havia a seguinte expectativa: "O profissional da tesoura lia os primeiros versos daquela baboseira, chateava-se, saltava para o pé do texto - e liberava tudo, inclusive o que interessava ao compositor" (WERNECK, 2006, p.80).

Parece ser esse o caso com Vai levando, em que a situação que o sujeito se depara é tratada como se não houvesse mais jeito, como algo que não é passível de correção, de melhora; é como se fosse uma situação irreversível; que o fato de a gente não ter cura sugere que esse sujeito é incapaz de se modificar, seja em termos de comportamento ou de características morais ou de personalidade. $\mathrm{O}$ sujeito vive como dá, seguindo com a vida de acordo com os rumos que se apresentam, sem grandes perspectivas ou expectativas, conforme o sistema permite e procurando por brechas. Mesmo para o sujeito que tem fama e regalias, como a sua cerveja, a praia de Ipanema, as perspectivas são ruins. Tem um sistema cruel para enfrentar, no qual tem de encarar a vileza de quem está no poder e dos seus mandados. Porém, com toda dificuldade que se lhe apresenta, esse sujeito, que não

${ }^{39}$ Chico Buarque, Gilberto Gil, Caetano Veloso, Geraldo Vandré, com canções de protesto, e ainda Cacá Diegues e Glauber Rocha, no cinema, tornaram-se símbolos desse período. 
tem cura, pode ser aquele que continua a achar que há saída, que há solução. É um otimista. A gente também não tem jeito, e continua lutando, seguindo em frente, carregando uma chama que não pode apagar, que é a vontade de ver as mudanças e acreditar nelas.

Em outra canção que se refere ao não tem jeito de forma muito contundente, O que será (À flor da pele) ${ }^{40}$, Chico Buarque apresenta um sujeito que está com seus sentimentos e emoções aflorando, e quando assim alguém se encontra, não é possível esconder, fingir, disfarçar. Não há o que se faça para mudar a situação.

O que será que me dá
Que me bole por dentro, será que me dá
Que brota à flor da pele, será que me dá
E que me sobe às faces e me faz corar
E que me salta aos olhos a me atraiçoar
E que me aperta o peito e me faz confessar
O que não tem mais jeito de dissimular
E que nem é direito ninguém recusar
E que me faz mendigo, me faz implorar
O que não tem medida, nem nunca terá
O que não tem remédio, nem nunca terá
O que não tem receita
...

O sujeito está tomado por um sentimento avassalador, que desperta todos os seus sentidos, que o vira do avesso e que ele não é capaz de identificar. Ao longo da letra da canção, descreve o poder do sentimento que toma conta de seu corpo, o que ele desperta em si. O ardor, o tremor, o clamor dos órgãos. O sujeito se encontra no auge do despertar de seus desejos mais carnais, o ímpeto toma conta do seu ser. Toda a sensualidade o invade. Para ele, não há remédio, reza ou súplica que aplaque o que sente. Tudo que está vivenciando está além da sua compreensão. É algo que não é plausível. Nada do que possa ser concebido como solução dará resultado. Essa avalanche de emoções, que o sujeito assume que não tem como controlar, nem disfarçar, e que não tem mais jeito, é irremediavelmente impossível tentar esconder.

Por que dois exemplos de canções com não tem jeito? Primeiro para reforçar a presença de uma locução recorrente no universo das canções pesquisadas, assim

${ }^{40}$ Disponível em: <http://letras.mus.br/chico-buarque/1217237/>. Acesso em: 22 nov. 2012. 
como no universo social. Segundo, por seu significado se referir a algo que não tem solução, por se tratar de situação irreversível e que, de certa forma, opõe-se ao dar um jeito de/para. Em suma, pode-se observar que, de certa forma, não tem jeito contrapõe-se ao "jeitinho".

E o "jeito" com "jeito" de "jeitinho", tem? Em $A$ vida é dura", da dupla de compositores Michael Sullivan e Paulo Massadas, apesar de a referência ser em termos de maneira e modo, o fato é bem típico no "jeitinho" brasileiro. Entre os pontos sobre os quais se pode discorrer, tem-se ainda "jeito" como caráter, índole, que reforça a questão sobre quem é esse cidadão.

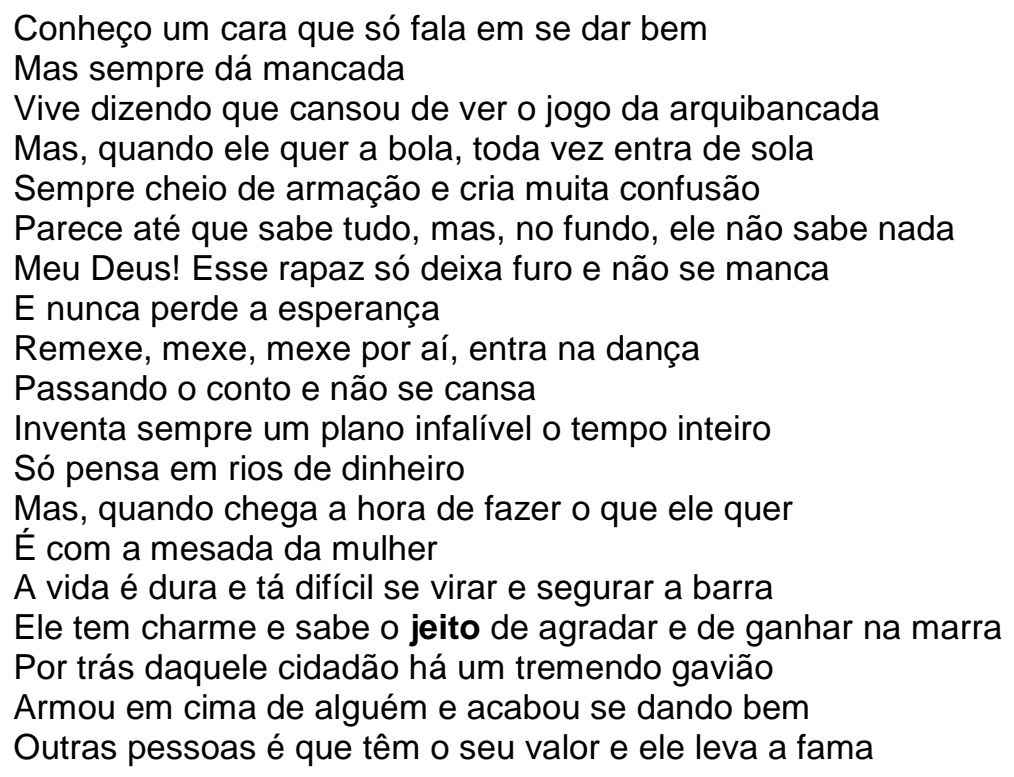

Quem não conhece um sujeito que onde chega quer se impor pelo fato de achar que entende de tudo? É capaz de realizar o que os outros não conseguem? Diz que tem tino comercial, visão empresarial, muitos planos em mente, está em vias de começar seu próprio negócio? Patrão não é para ele. Esse sujeito com esse "jeito" é o típico "malandro", que tem sempre planos mirabolantes de ganhar dinheiro, ficar rico sem fazer esforço, só na maciota. É um profissional do "jeitinho". Usa de expedientes e artifícios para tirar partido de situações, conta histórias com dramas pessoais para angariar simpatia das pessoas e envolve quem puder em

${ }^{41}$ Disponível em: <http://letras.mus.br/michael-sullivan/965844/>. Acesso em: 09 ago. 2011. 
seus 'contos do vigário'. Com charme, normalmente, conquista as pessoas e acaba sempre conseguindo o que quer.

Esse foi um caso típico do "jeitinho" - malandragem, a arte de sobreviver nas situações mais difíceis. Interessante observar que a malandragem não é colocada como opção. Segundo Souza (2008, p. 17), é a precarização das condições de vida dos trabalhadores, de um modo geral, que leva ao surgimento da malandragem e seus tentáculos, como o "jeitinho".

Outra acepção bastante importante e que se aproxima muito do "jeitinho" é dar um jeito, pois é quando o sujeito faz o 'necessário' para alcançar um objetivo. Usa de toda habilidade para contornar uma situação difícil e solucioná-la. Para resolução ou remoção do problema, os meios podem ser usuais ou alternativos, "não convencionais".

Relativo ao uso das letras das canções, elas deram concretude à ocorrência das palavras e expressões e tiveram o papel de me auxiliar no levantamento das palavras-chave e no afunilamento das questões e tópicos a serem abordados à frente. Faz-se importante diferenciar neste trabalho melodia e letra como fazem Tatit e Lopes (2008, p. 12). Estes autores estabelecem os termos "sons" musicais para a melodia e "conteúdos" da letra para a letra propriamente dita, e que a união desses dois componentes, letra e melodia compõem a canção. Assim, Tatit e Lopes (p.11) justificam o uso de canções em estudos semióticos:

\begin{abstract}
Mesmo que nos restrinjamos ao núcleo mínimo de identificação de uma canção - uma letra cantada com uma certa melodia -, é grande a riqueza de elementos que concorrem para os efeitos de sentido que ela pode produzir, sem falar nas inúmeras variáveis adicionais trazidas pelo arranjo ou pela interpretação de cada cantor. Tanto o componente linguístico quanto o melódico são portadores, cada qual, de muita informação que pode dizer substancialmente um bocado de coisas ao ouvinte.
\end{abstract}

Porém, minha proposta de trabalho é diferente. Apenas parte das letras foi analisada no corpo do texto, sem que fosse considerado o tratamento musical que Ihes foi dado em cada versão, por interessar-me o conteúdo em torno dos "jeitos".

Em relação às letras de canções, a princípio, as ocorrências eram relacionadas às lembranças, observações. No entanto, tal forma era pouco producente: as ocorrências escasseavam e havia necessidade de certo procedimento, como o recurso da linguística de corpus. Para tanto, recorri ao 
buscador Google, digitava o vocábulo ou a locução e fazia uma 'varredura' por aproximadamente dez páginas. Procurei contemplar as acepções mais marcantes. A escolha entre as acepções recorrentes foi particularmente árdua. Busquei primar pela isenção em termos de gosto musical e estética. Havendo registro de autores renomados da música popular brasileira, eles tiveram a prioridade, por prazer estético, uma vez que os efeitos de sentido eram equivalentes.

De um universo de cerca de cento e cinquenta canções com o vocábulo jeito, cento e quinze apresentaram a acepção mais comum, modo, maneira, forma. Entre as locuções, cerca de quarenta, não tem jeito foi contemplada vinte e uma vezes. A soma não é exata, pois há algumas ocorrências de canções com locução e vocábulo. Há registro de locução para a qual não há verbete em nenhum dicionário: pegar de jeito, que abordo logo abaixo.

A segunda locução mais presente no universo pesquisado foi sem jeito, com nove registros.

Em terceiro, com cinco ocorrências, a locução pegar de jeito, expressão popular, sem entrada nos diversos tipos de dicionários, com um sentido de: se você bobear, não estiver atento, vai ver o que acontece, o que se pode fazer com você. Pode ser que o sujeito não tenha escolha, não tenha escapatória diante de um fato. Com conotação positiva, pode significar sedução, o que quer dizer que a pessoa que for pega de jeito será coberta de carinho. Há de se considerar o ponto de vista: para alguns pode significar algo sexualmente bom, que o sujeito conquistado não vai resistir aos encantos do sujeito conquistador. Já para outros, pode ter um caráter de dominação e intimidação. Mas se a conotação for negativa, existe um grande risco de o sujeito se dar mal. Pode significar que o sujeito vai aplicar um corretivo, por exemplo, em uma criança travessa que precisa se comportar, pode ser um castigo. Vale lembrar que, em sua maioria, as ocorrências de pegar de jeito são de conjuntos de pagode ou cantores e grupos com pouca projeção no cenário musical brasileiro, apesar da proximidade temática e de efeito de sentido com Ai se eu te pego, sucesso na interpretação de Michel Teló, que venceu a categoria de Top Canção Latina do Billboard Awards 2013.

Localizei ainda ocorrências como ajeitar, jeitoso e jeitão. 
Interessante 0 que se registra no Houaiss, na entrada para jeitão: Regionalismo: Brasil. Uso: informal: maneira de se apresentar; aspecto, aparência, jeito; modo característico ou peculiar de agir, de se relacionar; traço; modo faceiro, elegante de andar, falar, portar-se. As definições não se distanciam muito das diversas acepções de jeito. A interpretação vai depender do contexto. As ocorrências se deram em duas canções de autoria de Ary Barroso, Os quindins de laiá e Coisas de Carnaval.

Todos estes jeitos que desfilaram perante mim tiveram sua valia. Não pude ignorá-los, então, aqui, apresento o inventário construído a partir deles: jeito carinhoso; jeito boêmio; jeito de herói; jeito manso; jeito de achar que a vida pode ser maravilhosa; toma jeito, coração; do seu jeito; do meu jeito; desse jeito; seja do jeito que for; um jeito de não sentir dor; um jeito da gente ficar junto (sic); um jeito de eu enlouquecer; de jeito maneira; de um jeito ou de outro; de jeito algum; jeito de ser; do jeito que tem que ser; há de haver um jeito qualquer; aquilo se pega de jeito; jeito mansinho; jeito tristonho; jeito igualzinho; sempre do mesmo jeito; jeito de olhar; jeito estranho; a Bahia tem um jeito. Cada jeito com seu jeito.

\subsection{Do "jeito" ao "jeitinho"}

Concentrando a pesquisa do "jeito" em sua forma do diminutivo, "jeitinho", além das entradas de dicionário, deparei-me com alguns estudos sobre o que representa o diminutivo ${ }^{42}$ das palavras, o efeito de sentido que se passa com a sua escolha. Costa (2003) argumenta que “...o homem utiliza os diminutivos para poder expressar melhor as suas emoções e as suas intenções de modo espontâneo, impulsivo e não apenas utilizá-lo como diminuição de tamanho" (COSTA, 2003). A autora acrescenta, ainda, que "a significação dos diminutivos depende do contexto e só existe em relação a ele". Seguem alguns exemplos do uso do diminutivo "jeitinho" que constam desse trabalho, com a interpretação contextual, feita pela própria autora.

\footnotetext{
42 "Algumas palavras causam desconforto, por isso usamos o eufemismo. O diminutivo se presta muito a isso: serve para abrandar, para atenuar uma situação que, (segundo Veríssimo), 'na sua forma original são ameaçadoras demais'. [...] Deve-se tomar cuidado com o uso das palavras no diminutivo, pois em determinadas situações pode haver constrangimentos, ofender as pessoas, magoá-las. Por exemplo: 'Esse povinho não tem muita coragem.' Povinho - revela um grande desprezo pelas pessoas, por esse povo." (COSTA, 2003).
} 
"Ele com jeitinho, resolveu o impasse". Jeitinho: habilidade.

"Jeans com jeitinho parisiense". (JB, 07/05/03). Jeitinho: modo de ser.

"Prédio com jeitinho de chácara". Jeitinho: igual, com características de chácara.

"Aposentem o jeitinho" (JB, 26/10/02). Jeitinho: maneira de burlar a lei.

Os exemplos apresentados pela pesquisadora, com suas diferentes acepções, vêm reforçar o fato de que mesmo o diminutivo apresenta determinado espectro de significados. O "jeitinho" pode coincidir com algumas acepções de "jeito", mas essa questão das emoções estarem presentes, somadas a certa empatia envolvida no processo, criam novas perspectivas. A forma diminutiva do "jeito" atrelada à maneira de falar, o charme e a simpatia desempenham papel importante para a obtenção do "jeitinho". Junte-se ainda a cordialidade e a humildade e normalmente pode-se contar com a generosidade do interlocutor, no sentido de compreender e atender ao pedido.

Segundo Holanda (1995), no domínio da linguística, "a terminação 'inho', aposta às palavras, serve para nos familiarizar mais com as pessoas ou os objetos e, ao mesmo tempo, para Ihes dar relevo. É a maneira de fazê-los mais acessíveis aos sentidos e também de aproximá-los do coração" (HOLANDA, 1995, p. 148).

Some-se a isso a multimodalidade da fala, através de recursos verbais e visuais, a maneira de falar, a entonação, os trejeitos, os movimentos de cabeça e dos cabelos, a linguagem corporal, o apelo do charme e a simpatia. Todos esses fatores atuarão na construção do sentido do enunciado relativo ao "jeitinho".

Veremos o "jeitinho" a partir de mais letras de canções, a serem abordadas à frente.

O dicionário Houaiss, apesar do fato de possuir as entradas mais concisas, é o único que apresenta o verbete "jeitinho" com o significado de "jeito delicado". Em parte considerável das canções que foram pesquisadas para comporem este capítulo do trabalho, as ocorrências desse vocábulo parecem assumir essa acepção. É o caso, por exemplo, de Minha namorada ${ }^{43}$, composição do poeta Vinícius de Moraes.

Se você quer ser minha namorada

Ai que linda namorada

\footnotetext{
${ }^{43}$ Disponível em: <http://letras.mus.br/vinicius-de-moraes/49276/>. Acesso em: 21 nov. 2012. Parceria com Carlos Lyra.
} 


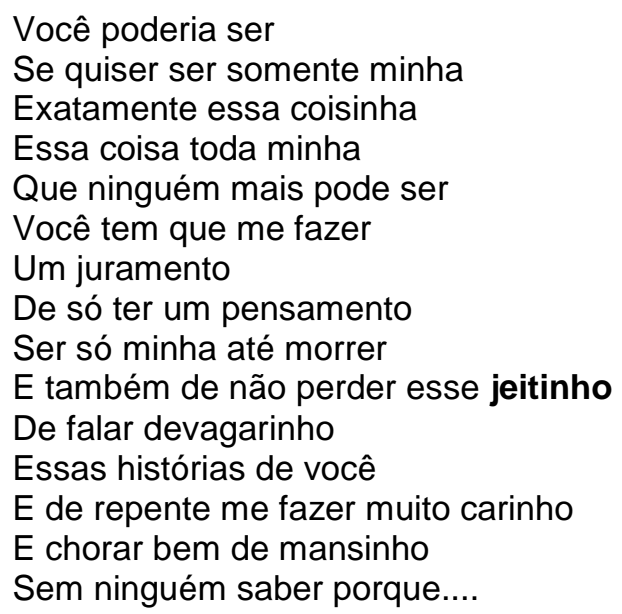

O "jeitinho", cantado pelo poeta, é um "jeitinho delicado". Essa namorada que esse sujeito deseja, pois ainda não a tem, é a pura delicadeza, que fala devagarinho, faz muito carinho e chora de mansinho. Em todas as referências do sujeito-poeta à namorada, percebe-se uma aura de candura no ar. Com essa forma de agir, com sua meiguice, sua fala mansa, ela conseguiria qualquer coisa do sujeito. O sujeito está hipnotizado, ouve as histórias, e assim parece querer perpetuar o momento. Ele a quer só para si, até morrer, para sempre. O uso do diminutivo, inclusive para outros vocábulos, mostra certa fragilidade, seja da namorada, que é uma "coisinha", como do sujeito, que escancara a sua vulnerabilidade perante a pretendida.

Analisando outro exemplo de letra, pode-se constatar o fato de que o "jeitinho" nem sempre é tão delicado assim. É o caso da canção Jeitinho dela ${ }^{44}$, de autoria de Tom Zé.

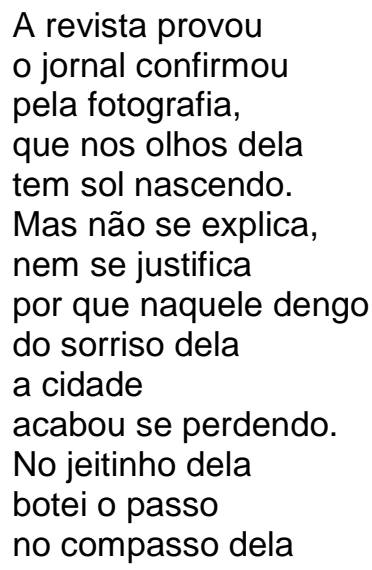

${ }^{44}$ Disponível em: <http://letras.mus.br/tom-ze/164137/>. Acesso em: 01 dez. 2012. 


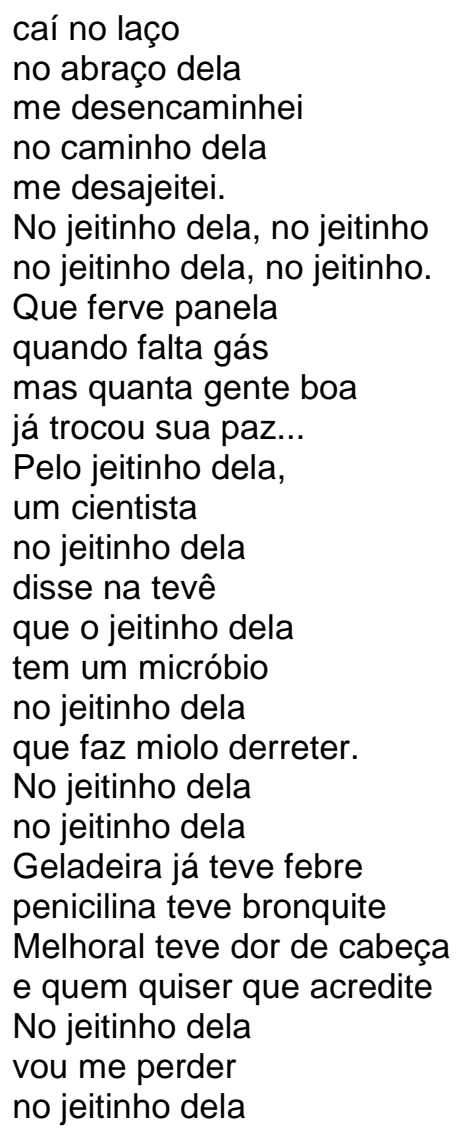

O jeitinho dela é sexy, é sensual, é poderoso, pois chega a fazer panela ferver sem gás, faz as pessoas perderem a cabeça, miolo ferver, leva a situações inusitadas, como geladeira com febre, penicilina com bronquite, melhoral com dor de cabeça, tudo às avessas. Apesar do dengo, ela não tem nada de delicado. Aliás, usa isso como arma poderosa para subverter a ordem estabelecida. Tudo leva o sujeito a se desajeitar. Segundo Houaiss, desajeitar faz perder o jeito, a forma, leva alguém a se tornar menos hábil nos movimentos, a pôr fora de ordem; desarranjar, desarrumar. Assim, desencaminhado e desarranjado, o sujeito perdeu o rumo e o prumo, por causa do "jeitinho dela".

Em outro exemplo de "jeitinho", apresento Capitu, de Luiz Tatit ${ }^{45}$, para análise.

De um lado vem você com seu jeitinho

Hábil, hábil, hábil

E pronto!

Me conquista com seu dom

${ }^{45}$ Luiz Tatit, professor titular do Departamento de Linguística da Faculdade de Filosofia Letras e Ciências Humanas da Universidade de São Paulo. Disponível em: <http://letras.terra.com.br/luiztatit/163882/>. Acesso em: 15 set. 2011. 


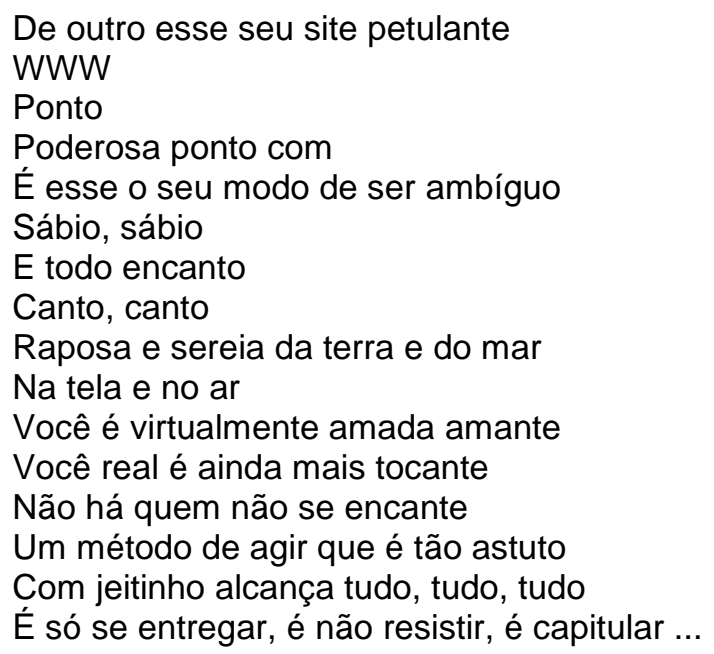

O jeitinho "hábil" da Capitu de Tatit assemelha-se à definição de "hábil" encontrada no Houaiss: dispõe de espírito e de caráter que a torna particularmente apta para resolver situações que se lhe apresentam ou para agir de maneira apropriada aos fins a que visa. Identifico no verbete a possibilidade de ênfase para uma Capitu astuta ou de modo de agir astuto, pois em hábil, continua Houaiss, teremos 'astuciosa, manhosa, sutil, esperta, sagaz'.

Capitu moderna, informatizada, dotada do próprio site, mas que parece conservar os mistérios da de Machado. Não há quem não se encante, captando os olhares, a mulher em milhares, a traição atraente, todos os ingredientes que vieram atormentar e torturar Dom Casmurro. Toda a manipulação atribuída a Capitu pode ser condensada no seu "jeitinho", que Tatit descreve com sutileza. Compõe os contrastes para manter o mistério: seu modo de ser é ambíguo, ela é virtual e real, terra e ar, tela e ar. Todas essas características e as que estão no nosso imaginário parecem compor o "jeitinho" de Capitu. Teria a protagonista certo "jeitinho brasileiro" na sua composição?

\subsection{Do "Jeitinho" ao "Jeitinho Brasileiro"}

Em comparação às formas e apresentações de "jeito", "jeitinho", "jeitão", cabe registrar a única referência explícita encontrada em dicionário formal, o Houaiss, ao "jeitinho brasileiro".

"Jeitinho": Regionalismo: Brasil. Uso: informal: maneira hábil, esperta, astuciosa de conseguir algo, especialmente algo que à maioria das pessoas se 
afigura como particularmente difícil; jeitinho brasileiro. Locução: "jeitinho brasileiro": maneira hábil.

Outra referência ao "jeitinho brasileiro" foi localizada no Dicionário inFormal, modalidade online. Esse dicionário apresenta-se como dicionário de português gratuito via internet, em que as palavras são definidas pelos usuários, numa iniciativa comunitária de se documentar online a evolução do português. Sem autores identificados ou preparados para a tarefa lexicográfica, ele é passível de apresentar definições parciais, até calcadas em opiniões pessoais, o que não chega a desqualificá-lo, mas exige cautela em sua análise. Ali, deparei-me com o seguinte registro para "jeitinho brasileiro" ${ }^{46}$ :

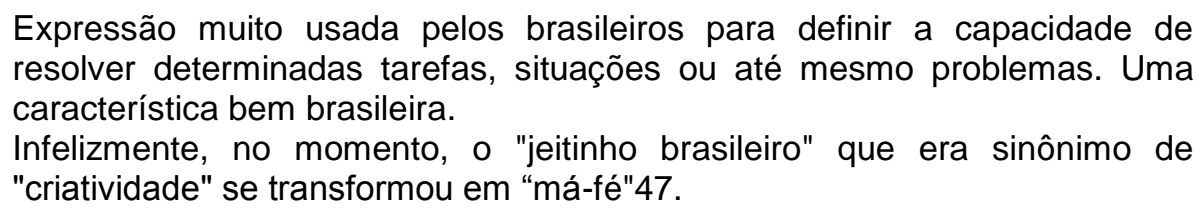
resolver determinadas tarefas, situações ou até mesmo problemas. Uma característica bem brasileira.

Infelizmente, no momento, o "jeitinho brasileiro" que era sinônimo de "criatividade" se transformou em "má-fé"47.

O "jeitinho brasileiro" é assim denominado quando o identificamos e queremos nomeá-lo, pois, em geral, usa-se "(dar) um jeitinho". As pessoas quando dele fazem uso assim o registram. Eis exemplo, extraído do Houaiss: Ex: Pode deixar que na hora $H$ aparece um amigo e dá um jeitinho.

Em trabalho específico sobre o "jeitinho" e outros clichês, Ferreira (2003) discorre que a marca do diminutivo opera certa significação, e que aponta para uma cumplicidade do sujeito de discurso. Ainda, segundo a autora, "... há mesmo uma simpática tolerância e uma aceitação consentida para com esse modo de ser que identifica e distingue o brasileiro" (FERREIRA, 2003, p. 77).

$\mathrm{Na}$ busca por exemplos em canções, encontrei referências ao jeitinho ligadas aos boêmios, cantados por Pixinguinha, Ary Barroso, Noel Rosa, Braguinha e tantos outros. Vou vivendo ${ }^{48}$, composição de Pixinguinha e Benedito Lacerda é uma das ocorrências.

Meu coração foi de bar em bar, Se perdeu nunca mais se achou

${ }^{46}$ Disponível em: <http://www.dicionarioinformal.com.br/jeitinho\%20brasileiro/>_._Acesso em: 08 nov. 2012.

${ }^{47}$ Definição enviada por Zé Brasilß (GO) em 10 jan. 2010.

${ }^{48}$ Disponível em: <http://letras.mus.br/pixinguinha/1093422/>. Acesso em: 02 dez. 2012. 
Foi vivendo assim

Sem ter ninguém para dizer um boa noite

E a penúltima nem tomou

Nem deu conta quando um garçom

O cobriu com uma noite de estrela para ele dormir.

$\mathrm{E}$... pelos bares por onde andei

Quantos copos eu já quebrei

Ao brindar muita paz e a Deus rogar aos amigos saúde.

Quando se foram sem um adeus

Se grudando nos versos meus

Como cacos de vidros espalhados

No meu coração.

Sonhou que era um chorinho

Tocado carinhoso

Pediu então um chopinho

Bem caprichado na pressão

E veio geladinho

Espuma no colarinho

Ah seu garçom vai com jeitinho

Pede outro chorinho sem sair do tom.

Meu coração vai vivendo assim

Mendigando de bar em bar

Uma esmola qualquer

De uma palavra de um jeito carinhoso.

Velhos amigos quero rever

Vendo à noite se transformar

Numa rede que vai entre nuvens me adormecer

Em cada bar

Que eu passei

Eu lavrei a inscrição

Trouxe aqui

Este meu coração

Para nele sua magoa afogar

Bar doce lar

Que aos boêmios a vida abrigou

Lua cheia ou minguante ou num quarto de lua

Há um lugar para essa dor.

...

Essa letra ilustra o "jeitinho" solicitado pelo sujeito boêmio em questão, pois está muito machucado, amargurado, abandonado, sem ter alguém que olhe por ele, exceto um garçom, que se preocupa em cobri-lo "com estrelas", o que faz dele um sem-teto, que dorme ao relento (o garçom o põe para fora a fim de fechar o estabelecimento, possivelmente o coloca em um banco de praça). Age como um pedinte, indo de bar em bar, sem amigos, não lhe resta outro lugar onde possa contar com o aconchego dos "inhos": pede um chopinho geladinho, espuma no 
colarinho, um chorinho, carinhoso, caprichado, com jeitinho, sem sair do tom. E vai vivendo assim, pedindo ao garçom por um "jeito" carinhoso e tendo por ele seus pedidos atendidos, que pode fazer aquilo apenas pela força de sua função, como obrigação. Segue vadiando, passando pelas fases da lua, tendo apenas as estrelas como cobertor, seja em que endereço for.

Os mesmos autores, boêmios dos anos trinta, cantavam o malandro dos morros cariocas. Porém, na busca realizada em dicionários, não encontrei nenhum registro de "jeitinho brasileiro" como "malandragem". As ocorrências surgiram com "jeitinho" ou com "jeito", como foi o caso de $A$ vida é dura.

Contudo, é João Bosco quem nos contempla com o Jeitinho Brasileiro ${ }^{49}$, que saúda e louva a terra, satiriza e caçoa de si mesmo, mostrando o "levar a vida" bem ao "jeito" do brasileiro, do "jeito" que der e vier.

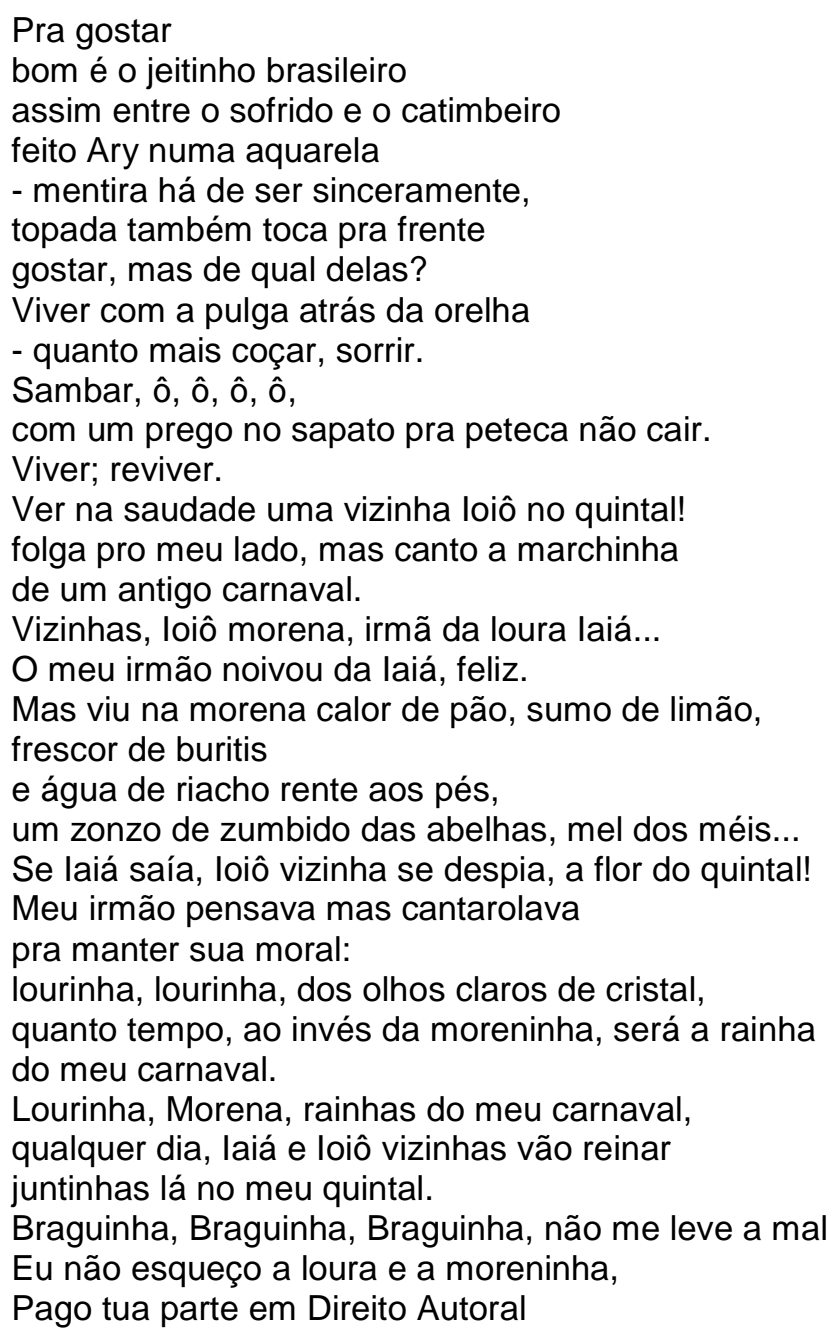

${ }^{49}$ Disponível em: <http://letras.mus.br/joao-bosco/151910/>. Acesso em: 02 dez. 2012. 
A canção revive Ary e Braguinha; loiô e laiá; reverencia a marchinha de carnaval, a aquarela e o samba; o irmão do enunciador é noivo da loura, mas se sente atraído pela morena. Lourinha e morena, irmãs, despertam a volúpia inclusive do enunciador, "vizinhas vão reinar juntinhas lá no meu quintal", em um bom modo de gostar, usando o "jeitinho brasileiro". Samba com o prego no sapato, mas não deixa a peteca cair; jeito sofrido e catimbeiro, nada é mais brasileiro; assim como pagar a parte do Braguinha em direito autoral, pronto para "dar o chapéu". Tudo isso é Brasil, tudo é "jeitinho", bem "jeitinho brasileiro"? É malandragem, um tipo de malandragem "do bem", que ajuda a viver?

Por outro lado, registramos também uma canção de autoria de Toquinho, com Maurizio Fabrizio e Guido Morra, Em Tournée $e^{50}$, que apresenta uma ocorrência da locução sem jeito e faz referência ao "jeito brasileiro" de ser. Como dito anteriormente, essas expressões devem ser analisadas dentro de um contexto, pois a menção feita por Toquinho não é a mesma de João Bosco, mais esperta e maliciosa.

Olhando o mapa eu me sinto distante de mim,

Aqui no meio do mundo, sem jeito.

E vendo o quanto estou longe lá de onde eu nasci,

Me dá um aperto no fundo do peito.

Nessa pausa de tournée,

Sinto o tempo aqui parado.

Olho a televisão sem ver,

Com o meu violão calado.

Da janela desse hotel

Vejo linda e branca lua.

A claridade lá do céu

É a mesma da minha rua.

É uma saudade de pele, de som e de aroma:

A tal saudade que é só brasileira.

E me surpreendo querendo mudar o idioma

Dessa rádio de língua estrangeira.

A arte de fazer nossa luz brilhar

Quando o dia parece estar sem saída.

A arte de arriscar e se proteger, de viver sem se arrepender,

Aprendendo a se refazer cada dia dessa vida.

Nessa pausa de tournée,

Lunes é segunda-feira.

Une chanson je voudre chantée

To my love questa sera.

Da janela desse hotel sonho sonhos de menino.

Vem a noite com seu véu e acalenta meu destino.

${ }^{50}$ Disponível em: <http://musica.com.br/artistas/toquinho/m/em-tournee/letra.html>. Acesso: 09 jul. 2014. 
Essa maneira, esse jeito de ser brasileiro

É a virtude e o problema da gente.

Nas ruas desta cidade me sinto estrangeiro

De um sistema solar diferente.

Esse jeito de ser brasileiro do Toquinho não é o mesmo do "jeitinho brasileiro". A distância da terra natal, de si mesmo, soa como se o sujeito não se encontrasse lá, na terra estrangeira. Parece empreender uma viagem para matar a saudade de sua terra, do céu, da lua e da rua. Sente a saudade da pele, do contato, do toque das pessoas que ama. Do som da nossa música, que faz inclusive o violão calar e da sonoridade do nosso idioma. Saudade que é conhecida somente no galego e no português, por isso, a tal saudade que é só brasileira, que precisa de uma expressão inteira para ser expressa no inglês, por exemplo, 'I miss you'. Palavra utilizada para expressar a mistura dos sentimentos de perda, falta, distância e amor. E continua o sujeito, com a saudade do aroma de nossos frutos, da maresia, do café, da cachaça e das comidas. Sente falta do jeito de ser da gente, de achar saída para tudo. De se arriscar, mas se precaver, viver sem se preocupar com o que passou. Aprender a dar a volta por cima e a tirar proveito das adversidades. Ressurgir, reconstruir-se.

Em comum com o "jeitinho" de João Bosco, Toquinho retrata esse jeito de ser, de viver e reviver do brasileiro; do se arriscar na vida; do "levanta sacode a poeira e dá a volta por cima". É virtude e é defeito do jeito de ser brasileiro.

Fazer o quê? Brasileiro é assim. Como se não tivesse remédio, como um planeta à parte, de outro sistema solar, como diz Toquinho. Soa como se fosse um estigma. Para o bem e para o mal. Por isso o jeitinho positivo e negativo. Pelos antagonismos, pelas oposições. O "jeitinho", em suma, é um termo complexo, na medida em que conjuga o mais e o menos, o sim e o não, o positivo e o negativo.

Darcy Ribeiro, antropólogo, educador, escritor e um dos maiores intelectuais que o Brasil teve, assim escreve sobre as características do povo brasileiro:

Outros intérpretes de nossas características nacionais veem os mais variados defeitos e qualidades aos quais atribuem valor casual. Um exemplo nos basta. Para Sérgio Buarque de Holanda seriam características nossas, herdadas dos iberos, a sobranceria hispânica, o desleixo e a plasticidade lusitanas, bem como o espírito aventureiro e o apreço à lealdade de uns e outros e, ainda, seu gosto maior pelo ócio do que pelo negócio. Da mistura de todos esses ingredientes, resultaria uma certa frouxidão e anarquismo, a falta de coesão, a desordem, a indisciplina e a 
indolência. Mas derivam delas, também, certo pendor para o mandonismo, para o autoritário e para a tirania. [...] Como quase tudo isso são defeitos, devemos convir que somos um caso feio, tamanhas seriam as carências de que padecemos. Seria assim? Temo muito que não. Muito pior para nós teria sido, talvez, e Sérgio o reconhece, o contrário, de nossos defeitos, tais como, o servilismo, a humildade, a rigidez, o espírito de ordem, o sentido de dever, o gosto pela rotina, a gravidade, a sisudez. Elas bem poderiam nos ser ainda mais nefastas porque nos teriam tirado a criatividade do aventureiro, a adaptabilidade de quem não é rígido mas flexível, a vitalidade de quem enfrenta, ousado, azares e fortunas, a originalidade dos indisciplinados. Fala-se muito, também, da preguiça brasileira, atribuída tanto ao índio indolente, como ao negro fujão e até às classes dominantes viciosas. Tudo isso é duvidoso demais frente ao fato do que aqui se fez. $E$ se fez muito, como a construção de toda uma civilização urbana nos séculos de vida colonial, incomparavelmente mais pujante e mais brilhante do que aquilo que se verificou na América do Norte, por exemplo (RIBEIRO, 1995, p. 451).

No balanço de qualidades e defeitos, ora apresentados por Holanda (1995), ora por Ribeiro, as características se completam ou se contrapõem e justificam a dubiedade que cerca também o "jeitinho brasileiro".

A partir do levantamento lexical realizado com o vocábulo "jeito", as suas locuções e parassinônimos, as acepções mais recorrentes receberam uma atenção especial, com apresentação de estudo similar para cada uma delas. São elas: habilidade, improviso, flexibilidade, criatividade, favor, corrupção. Jeitinho criativo e flexibilidade moral serão considerados pelas situações surgidas na coleta de dados iniciais para a formação do corpus. Não há a intenção de classificar, pelo menos a priori, o vocábulo como positivo ou negativo. O estudo lexical e, posteriormente, o estudo dos casos por meio dos textos selecionados, é que pode proporcionar tal avaliação.

\subsection{Habilidade}

Tem de ter habilidade... Para dançar o créu. Para os Parâmetros Curriculares Nacionais (PCN), habilidade e competência. Habilidade e destreza para exercícios ginásticos. Habilidade para lidar com as pessoas. Habilidade para contornar situações difíceis.

"Habilidade" é importante quando se analisa o vocábulo "jeito", pois é uma das entradas mais recorrente nas definições pesquisadas.

O Aulete registra habilidade como qualidade de quem é hábil; capacidade de fazer alguma coisa bem. Figurado: capacidade de dizer ou fazer algo sem melindrar 
ou ofender alguém (especialmente suscetível a se sentir ofendido) ou capacidade para contornar alguma situação embaraçosa ou constrangedora.

No Houaiss, a definição é qualidade ou característica de quem é hábil. Outra entrada refere-se aos exercícios ginásticos, e não atende aos interesses desta pesquisa.

Tanto o Aulete quanto o Houaiss apresentam o vocábulo como a qualidade de quem é hábil. Houve a necessidade de expandir a pesquisa para o adjetivo hábil, e assim foi possível obter um resultado mais amplo em termos de acepções, como se pode observar a seguir.

No Aulete, a entrada que amplia o sentido de “jeito", relacionado a ser hábil, é ágil, capaz; astucioso, esperto, manhoso, sagaz.

No Houaiss, hábil é o que se diz de quem tem uma disposição de espírito e de caráter que o torna particularmente apto para resolver as situações que se lhe apresentam ou para agir de maneira apropriada aos fins a que visa; astucioso, sutil, manhoso; esperto, sagaz.

Para o "jeitinho", a qualidade de ser "hábil" apresenta características que tornam um sujeito capaz de superar dificuldades, resolver situações, utilizando esperteza e agilidade de ação e de raciocínio, solucionando problemas, às vezes, com o uso de certos macetes. Utilizando ainda as letras de canções como ilustração, eis Só tem jogador ${ }^{51}$, de Gabriel O Pensador, em que se encontra a ocorrência para "habilidade":

\footnotetext{
Passa bola vai ter futebol

É no frio, no calor, na chuva ou no sol

Cada jogo é uma final

No estádio, no ginásio ou no meu quintal

Tá no sangue, no DNA

Na barriga da minha mãe eu já sabia chutar

Hoje eu tenho que me desdobrar

Bato o escanteio e corro pra cabecear

Se liga aí que o nosso jogo agora é de verdade

A vida é dura tem que ter responsabilidade

Não dá chutão, bota no chão, cadê a habilidade?

$O$ adversário muitas vezes chega na maldade

Atividade, corre atrás, mas não vai de primeira

Quem joga bem apanha mais, não pode dar bobeira

Mas se apanhar, eu bato a falta encobrindo a barreira
}

${ }^{51}$ Disponível em: <http://letras.mus.br/gabriel-pensador/1996599/>. Acesso em: 26 dez. 2012. 
E se a barreira pular, eu meto a bola rasteira.

$\mathrm{Na}$ canção predominam, basicamente, as figuras do futebol. Uma análise mais acurada do conteúdo da letra e da figurativização apresentada possibilita um paralelo com a rotina do sujeito e mesmo com o dia-a-dia do brasileiro, com a ginga, a necessidade de superar as dificuldades, de achar brechas para resolver os problemas. Ele faz várias coisas ao mesmo tempo, mostra desenvoltura para se desdobrar e executar tarefas simultaneamente. Apesar de a vida ser dura, precisa de responsabilidade, não pode bobear, senão apanha e leva rasteira da própria vida ou de adversários, que nem sempre agirão com honestidade. Deve superar barreiras, faça chuva ou faça sol. Todo esse jogo de cintura está no sangue, está no DNA desse sujeito.

\subsection{Improviso}

Vai na base do improviso... Fazer um discurso de improviso. Uma apresentação artística ou musical, às vezes, de improviso. Faltou o professor da matéria, entra o eventual, de improviso. Protagonista está doente, figurante entra... Quebrou o motor do carro alegórico, o povo empurra... Faltou médico no serviço público. Não tem como improvisar. É sofrimento para o usuário (ou contratam-se médicos cubanos... "jeitinho"?).

"Improvisar" é condição primordial do "jeitinho", pois compreende a realização de algo pelo sujeito, que não conta com os meios apropriados, não está preparado de maneira adequada e, normalmente, não conta com nenhum planejamento. Uma de suas características é a de que tem de solucionar o problema no momento em que ele ocorre, não há possibilidade de "deixar para depois".

Segundo Houaiss, "improvisação" é o ato ou efeito de improvisar. O mesmo dicionário apresenta "improvisar" como: fazer, arranjar de repente, sem preparação, organizar às pressas; engendrar na hora (mentira ou desculpa); inventar, mentir; invocar falsamente ou forjar (leis, documentos, costumes inexistentes); criar (objeto) com os recursos do momento; desempenhar (papel, função etc.) para o qual não se está habilitado. 
No Aulete encontram-se os seguintes registros: criar ou realizar algo sem preparo prévio; citar falsamente ou elaborar algo com intenção de enganar; forjar; assumir uma ocupação em caso de necessidade, sem estar preparado.

Essa junção do "jeito", do "jeitinho", com "improvisação" e "criatividade", pode encontrar respaldo em Barbosa (2006), ao citar um exemplo de jeito prático ${ }^{52}$ que, segundo ela, poderia ser considerado paradigmático na descrição de situações em que o "jeitinho" é definido como "criatividade", "improvisação" e esperteza do brasileiro. A autora assim expõe como as pessoas entendem o "jeitinho": "maneira especial de lidar com situações imprevistas; resolver alguma coisa no "sufoco" [...]" (BARBOSA, 2006, p.23).

Em Brasa $^{53}$, de Gabriel O Pensador, uma alusão ao nome do nosso país, Brasil, o autor mistura a "malandragem", o "jeitinho", o "improviso", o "nosso jeito de fazer amor" e o "nosso jeito de fazer justiça".

Um poeta já falou, vendo o homem e seu caminho:

"o lar do passarinho é o ar, e não o ninho"

E eu voei... Eu passei um tempo fora, eu passei um tempo longe.

Não importa quanto tempo, não importa onde.

Num lugar mais frio, ou mais quente de repente, onde a gente é esquisita, um lugar diferente.

Outra língua, outra cultura, outra moeda.

É, vida dura mas eu sou duro na queda.

Eu tô morrendo de saudade, tô morrendo de saudade...

Da mulata oferecida, do pagode malfeito, de torcer na arquibancada pro meu time do peito.

A pelada sagrada com a rapaziada, o sorriso desdentado na rodinha de piada.

Da malandragem, da nossa malícia, da batida de limão, da gelada que delícia!

Eu tô morrendo de saudade, tô morrendo de saudade...

Do jornal lá na banca, da notícia pra ler, das garotas dos programas da TV.

Do jeitinho, do improviso, da bagunça geral.

Do calor humano, do fundo de quintal.

Do clima, da rima, da festa feita à toa - típica mania de levar tudo na boa do contato, do mato, do cheiro e da cor.

E do nosso jeito de fazer amor.

Eu e minha gente, coração mais quente, refeição no forno.

Água no feijão, tô na área, bichinho.

Se me derrubar... eu não tô mais sozinho.

Tô de volta sim senhor.

Sou brasileiro, com muito orgulho, com muito amor.

${ }^{52}$ O exemplo será utilizado e analisado a posteriori. Refere-se ao relato da atitude da tropa brasileira durante a Campanha dos Apeninos, na Segunda Guerra Mundial.

${ }^{53}$ Disponível em: <http://letras.mus.br/gabriel-pensador/96117/>. Acesso em 26 dez. 2012. 
Mas o amor é cego.

Devo admitir, devo e não nego, que aos poucos fui caindo na real, vendo como o Brasa tava em brasa, tava mal.

Vendo a minha terra assim em guerra, o meu país... não dá, não dá pra ser feliz.

Eu tô morrendo de vergonha, tô morrendo de vergonha...

Da mulata oferecida, do pagode malfeito.

Morrer na arquibancada pro meu time do peito.

O salário suado que não serve pra nada, o sorriso desdentado na rodinha de piada.

Da malandragem, da nossa milícia, da batida da PM, porrada da polícia.

Eu tô morrendo de vergonha, tô morrendo de vergonha...

Do jornal lá na banca, da notícia pra ler, das garotas de programa dos programas da TV.

Do jeitinho, do improviso, da bagunça geral, do sorriso mentiroso na campanha eleitoral.

Do clima de festa, da festa feita à toa - ridícula mania de levar tudo na boa do contato, do mato, do cheiro da carniça

$E$ do nosso jeito de fazer justiça.

Mas eu vou ficar no Brasa porque o Brasa é minha casa, casa do meu coração.

Mas eu vou ficar no Brasa porque o Brasa é minha casa e a minha casa só precisa de uma boa arrumação

$\ldots$

O sujeito em questão morou no exterior, teve outra experiência de vida, pois julgava isso importante. Conheceu outras pessoas, outras culturas, outro idioma, ampliou sua visão de mundo, desenvolveu um olhar crítico. Sentiu falta de casa, da sua terra natal, mas tinha de ser forte, não podia esmorecer. Viveu a experiência do subemprego, de ter de trabalhar para se sustentar, e de estar na clandestinidade, de mal ter o dinheiro para sobreviver. Seguiu o sonho de grande parte dos brasileiros imigrantes, de fugir do subdesenvolvimento de seu país, de fazer riqueza. Não era o mar de rosas que sonhou, e sentiu na pele o que é estar na ilegalidade. Bateu a saudade do país, tratado de forma tão carinhosa - Brasa - e quando isso aconteceu, esqueceu o que motivou sua partida. Sentiu falta até das coisas que sempre renegou. O retorno o fez avaliar que Brasa era o seu lugar. Declarou seu orgulho e seu amor. Mas, como diz o ditado popular, "tudo que é bom, dura pouco", o sujeito caiu na real. Brasa não era mais só o país de clima quente, do calor humano, da gente com o coração quente, também estava pegando fogo, política e economicamente. E o pior: sem esperança no futuro. Os antagonismos começaram a surgir para o sujeito: do "tô morrendo de saudade" ao "tô morrendo de vergonha". 
Saudade e vergonha da mulata oferecida e do pagode malfeito. Do clima, da rima, da festa feita à toa: primeiro é uma típica mania de levar tudo numa boa e, depois, "ridícula mania de levar tudo na boa". Da malandragem, da malícia e da malandragem e da milícia. Do churrasco e da chacina de domingo. De torcer e morrer na arquibancada. Tudo isso associado à bagunça geral. Sentiu revolta, frustração e depressão. Mas vai ficar, porque o país é a sua casa. E é a casa do coração deste sujeito, e o que ela precisa é de arrumação. Arrumação associada à limpeza, pois precisa de água e sabão. Faz-se necessário: a conscientização, a comunicação, a manifestação, a indignação, a participação. É um clamor, que quer criar eco e conclamar adeptos. É uma declaração de amor, que está presente em referência posterior na letra da canção.

\subsection{Flexibilidade}

O contorcionista é flexível. Assim como o ginasta. O horário pode ser flexível. Os pais e professores também. Aceitam discutir, argumentar, respeitam opiniões. $O$ chefe também pode ter maleabilidade. Flexibilidade para atuar em diferentes áreas ou tarefas.

A "flexibilidade" pode ser entendida como uma forma de "jeito" quando se pensa no "jeito criativo": é o conhecido "jogo de cintura", o adaptar-se a situações adversas, procurar e encontrar saídas, ainda que não as convencionais. É uma expressão coloquial, comum, por exemplo, nos meios empresariais e organizacionais, que requer que o sujeito seja maleável e que se adapte às diversas situações.

Em dicionário, encontrei no Aulete como a qualidade do que é flexível, maleável; capacidade de ser ágil, de ter ligeireza de movimentos; propriedade de ser dócil às manipulações; figurado: capacidade de quem demonstra compreensão, de quem sabe considerar as coisas com espírito maleável; capacidade para atuar em variadas formas de atividade e estudos.

As entradas no Houaiss são bem similares, acrescentando poucas acepções diferentes: qualidade do que é flexível, maleável; facilidade e ligeireza de movimentos; agilidade, elasticidade, elegância; propriedade do que é dócil ao manejo; maleabilidade; derivação: sentido figurado: característica de quem é 
compreensível; brandura, docilidade; aptidão do espírito para se aplicar a diversas ocupações e estudos.

Novamente retornei à definição do adjetivo, no sentido de ampliar as possibilidades de encontrar outras acepções. No Houaiss, flexível apresenta-se como o que se dobra ou curva com facilidade; arqueável, flexo; que revela agilidade; elástico, elegante; fácil de manejar; domável; que se acomoda facilmente às circunstâncias, que é facilmente influenciável; dócil, maleável, compreensível; que tem aptidão para diferentes atividades.

Para explicar o que é flexível existe uma expressão popular, muito utilizada: “jogo de cintura”. Eis a definição encontrada para a expressão em um dos dicionários ${ }^{54}$ online pesquisados:

\begin{abstract}
O termo jogo de cintura é utilizado quando a pessoa tem que ter flexibilidade em seu modo de agir, ou seja, é necessário "mexer a cintura" para ultrapassar os vários obstáculos e dificuldades que Ihe são impostas, em especial quando ocorrem novas situações. Jogo de cintura é uma gíria muito utilizada em todo o Brasil, por pessoas de várias idades, em especial no meio empresarial e nas relações entre pessoas não tão próximas.
\end{abstract}

E para "jogo de cintura", no Aulete, encontramos: Brasileirismo popular especialmente usado no futebol: flexibilidade corporal, agilidade e destreza com que, com movimentos de corpo, o jogador engana o adversário, rouba a bola ou a controla, etc.; figurado: flexibilidade no comportamento, facilidade de se adaptar a situações diferentes mudando de ideia, atitude, etc. Houaiss assim o registra: Derivação: sentido figurado. Regionalismo: Brasil. Uso: informal: flexibilidade na solução de problemas ou situações difíceis; capacidade de não se ater a modelos ou padrões rígidos de pensamento ou de comportamento.

$\mathrm{Na}$ associação com a letra de canção, o registro é Falcão ${ }^{55}$, um rap de autoria de MV Bill, cujo conteúdo faz referência ao emprego de meninos pelo tráfico, com a tarefa de vigiar a comunidade, para sinalizar a aproximação ou a presença da polícia ou grupos rivais. Apresento apenas a parte final da letra.

\footnotetext{
${ }^{54}$ Disponível em: <http://www.significados.com.br/jogo-de-cintura/>. Acesso em: 24 dez. 2012.

${ }^{55}$ Disponível em: <http://letras.mus.br/mv-bill/611011/>. Acesso em: 26 dez. 2012.
} 
Sujou, lombou, sangue ferve, quem faz a segurança do asfalto, ele chama de verme, paquiderme a doença tá na pele, o olho avermelhado anuncia que ele tá na febre.

Parafal ${ }^{56}$ no último modelo, o sonho de criança cresceu e virou pesadelo.

Se é meio termo, dormindo com o inimigo, escravo do perigo, traição de camarada, fez feio no desenrolado, rachou a cara.

Menos um no caminho, um a mais na patrulha da cidade.

Necessidade, excesso de vontade, neurótico, flexível quando tem que ser, o que vale é o proceder, sem caozada ${ }^{57}$ pra não ficar fudido.

De menor, 15 anos, ferramentas e o olhar de bandido.

(Refrão)

Jovem, preto, novo, pequeno.

Falcão fica na laje de plantão no sereno.

Drogas, armas, sem futuro

Moleque cheio de ódio invisível no escuro puro.

É fácil vir aqui me mandar matar, difícil é dar uma chance à vida.

Não vai ser a solução mandar blindar.

O menino foi pra vida bandida.

Falcão também é o nome do documentário produzido pelo rapper MV Bill, autor da letra, que retrata a vida dos meninos que levam esse nome por sua atuação dentro do intrincado mundo do tráfico de drogas nas favelas.

A convivência precoce com as armas, a morte, a falta de esperança, a compra e a venda da droga, o uso dos fuzis, sem perspectiva para o futuro. O poder de decidir sobre quem matar, sem precisar poupar nenhuma vida, é o matar ou morrer. Crianças sem infância, tomando decisões de uma vida adulta precoce. Esse sujeito-jovem que não dorme, tem um ódio latente e geralmente está "chapado". Quando ele "cai" e é capturado pelo inimigo, seja policial ou gangue rival, vai apanhar calado. Ou será "flexível", e se não quiser "dançar", terá de trair, e sabe que uma vez sendo "traíra", não tem muito que esperar. Daqui ou dali, do tráfico ou da polícia, logo vai surgir alguém para "apagá".

O sujeito-jovem é retratado no rap como produto do seu meio. O rapper, em geral, manifesta preocupação com a situação social ao seu redor, se investe do papel de porta-voz da comunidade e assume para si a responsabilidade de escancarar a realidade, ao mesmo tempo que procura alertar outros jovens dos riscos a que estão expostos. Denuncia a lei da selva, absurda e violenta, e critica o

${ }^{56}$ O PARAFAL é uma versão do fuzil FAL M964 com coronha rebatível e atende a todos os requisitos técnicos e operacionais estabelecidos pelo Exército Brasileiro. Disponível em:

<http://www.imbel.gov.br/index.php/pt/sample-content-mainmenu-58/armamentos/fuzis/parafal>.

Acesso em: 01 jul. 2014.

${ }^{57}$ Caozada: provocar ou irritar alguém. Disponível em:

<http://www.dicionarioinformal.com.br/caozada/>. Acesso em 01 jul. 2014. 
que eles consideram que foi incorporado à cultura brasileira: achar que é normal ver negros pobres, presos ou mortos. Descreve também um forte sentimento arraigado de pertencimento ao lugar onde nasceu e vive.

O professor e educador Juarez Dayrell, coordenador do Observatório da Juventude e integrante do Programa Ações Afirmativas, ambos da UFMG, pontua:

O estilo rap estimula o jovem a refletir sobre si mesmo, sobre seu lugar social, contribuindo para a ressignificação das identidades do jovem como pobre e negro. Ao mesmo tempo, ele cria uma forma própria de o jovem intervir na sociedade, por meio das suas práticas culturais (DAYRELL, 2002, p. 133).

As letras de rap, ao mesmo tempo em que fazem o jovem refletir, apresentam práticas sociais e culturais e a busca de relações, familiares ou de amizade, que vão ajudá-lo a construir uma identidade positiva. 'Flexibilidade' é uma das palavraschave para a busca e obtenção dessas referências nesse mundo retratado no rap. 0 sujeito precisa ser arguto, sagaz, agir com ginga e jogo de cintura para conseguir sobreviver nesse mundo de desafios.

\subsection{Criatividade}

Criatividade em diversas áreas: artística, esportiva, científica. Criatividade tem o repentista, o coreógrafo, o publicitário, o marqueteiro, o designer, o pintor, o compositor, o jogador, o pesquisador, o rapper. O artista, enfim...

A criatividade é e continuará sendo um assunto de constantes debates e investigações. Uma definição, segundo Lubart (2007), é aceita pela maior parte dos estudiosos do assunto:

A criatividade é a capacidade de realizar uma produção que seja ao mesmo tempo nova e adaptada ao contexto na qual ela se manifesta58. Essa produção pode ser, por exemplo, uma ideia, uma composição musical, uma história ou ainda uma mensagem publicitária. [...] uma produção criativa não pode ser simplesmente uma resposta nova. Ela deve igualmente ser adaptada, ou seja, deve satisfazer diferentes dificuldades ligadas às situações nas quais se encontram as pessoas. [...] A importância relativa da novidade e da adaptação depende, assim, da natureza da tarefa proposta aos sujeitos: por exemplo, o critério de adaptação é mais fortemente valorizado dentro das produções criativas dos engenheiros do que na dos artistas (LUBART, 2007, p. 16).

${ }^{58}$ (Amabile, 1996; Barron, 1988; Lubart,1994; MacKinnon, 1962; Ochse, 1990; Sternberg e Lubart, 1995 apud LUBART, 2007, p. 16). 
Assim, criatividade, principalmente para resolver ou contornar problemas de difícil solução, é outra característica do "jeitinho". A criatividade do "jeitinho" é a que se assemelha a do engenheiro: é a da busca pela solução na qual o caráter de novidade não é tão valorizado. A questão da novidade pode não ser, de certa forma, tão relevante, pois, como acrescenta Lubart (2007), "uma ideia pode ser nova para uma dada pessoa, mas não ser para uma outra, de acordo com suas experiências anteriores" (LUBART, 2007, p.17).

No exterior, profissionais brasileiros são geralmente louvados por sua criatividade ${ }^{59}$, por descobrirem uma saída quando outros não a veem. Criatividade exercitada quando surgem situações adversas, pelo fato de o sujeito normalmente não poder contar com estruturas ou padrões estabelecidos a serem seguidos por todos, em qualquer situação. O sujeito se vê obrigado a desenvolver formas para lidar com os mais diversos tipos de problema.

O Aulete apresenta criatividade como capacidade de inventar, criar, conceber na imaginação; qualidade de quem ou do que é inovador, criativo, original; originalidade.

Segundo Houaiss, criatividade é qualidade ou característica de quem ou do que é criativo; inventividade, inteligência e talento, natos ou adquiridos, para criar, inventar, inovar, quer no campo artístico, quer no científico, esportivo etc.

Outras entradas, como a "criatividade linguística", não foram levadas em conta, pois não acresciam novas contribuições para o corpus da pesquisa.

Em relação ao conteúdo da letra de um grupo de rap, Cone Crew Diretoria, Cria Atividade ${ }^{60}$, eis como ocorre o vocábulo:

\footnotetext{
Eu sou cria alimento a minha ideologia Com criatividade quem é cria de verdade Cria músicas instantâneas sobre histórias sombrias Mente espontânea é necessária hoje em dia Sem ter muita mordomia improviso as correria

Depois do alarde feito arde na real verdade Que te cria atividade atinge a mente em pleno auge Criação te invade e age fase ...
}

\footnotetext{
${ }^{59}$ Baseado em entrevista exibida em nov. 2008, no programa Mesa de Negócios sobre o Jeitinho brasileiro no exterior. Reportagem de Inácia Soares com Ricardo Perrone, consultor de empresas. Disponível em: http://vod.com.ng/en/video/ZzoWfuyDnac/Jeitinho-brasileiro-no-exterior-ReportagemInácia-Soares-com-Ricardo-Perrone>. Acesso em: 11 jul. 2014.

${ }^{60}$ Disponível em: <http://letras.mus.br/cone-crew-diretoria/1771454/>. Acesso em: 26 dez. 2012.
} 
A mentira vira verdade eu busco a criatividade

Calma luz serenidade objetividade quando cria a frase

Mas não cria o pensamento que se perca em sua base

Cria a cena e pega a frase por mais que no fim me arrase

Bote a cara e não se cale, que se faça e não se fale

Quem cria atividade se cria nessa cidade

Com criatividade se cria a qualidade

Agilidade você sabe tem que ter pra escapar

$\cdots$

Me rego em abundância se a certeza de onde é a fonte

Microfone é só pra quem possui habilidade

Onde se cria na cidade disse criatividade

Sem idade é uma infinidade só pra um termo

Te acompanha até a morte tá contigo desde o berço

Ei cria, criatividade fuja das atrocidades

Ainda tem muito trabalho então trabalhe que deus sabe

Muito vale a vida de quem tem dignidade

A base fase viagem com criatividade nade contra a maré

Se for necessidade faça sua parte

Grave em grave underground quem não sabe é fase de arte

Mutirão debate essência de rua não deixe que se apague

Defasagem afagem viagem laje tiragem

Magal mortagem fatal sincronia do mal

Soberania terral quanto distúrbio mental

Surge a criatividade real cria espacial

Só original som da glória mortal foda-se o social

Verde é essencial natureza informal cultura emocional

Rap direcional, não tem igual

Dias que sobrevivi, promessas que já cumpri

Tentações que resisti, quantas lições que aprendi

Graças a deus tô aqui, com bom psico ao nogi

Mente pra evoluir, versos pra reproduzir

Receitando a de verdade, cria de atividade

Com criatividade pra procriar atividade

Que não descobri segredos, vi o doce onde era azedo

Desde cedo hoje percebo, sou coragem onde houver medo

A criatividade abordada pelo grupo de rap, Cone Crew Diretoria, apresenta a tematização associada, principalmente, à produção artística, mas sem abandonar o seu universo, a vivência na periferia, as perspectivas de quem ali vive. A habilidade com as palavras do sujeito criativo pode sensibilizar seu interlocutor, que é o jovem da periferia, e que, muitas vezes, vive no limiar da precariedade, sem rumo. Alerta para que o jovem fuja das atrocidades, das histórias sombrias, e nade contra a corrente. Convida-o para viver a camaradagem, a família, a memória dos amigos, o trabalho com dignidade. A sobrevivência, a resistência às tentações e a evolução da mente são etapas. A criatividade propicia calma, luz, serenidade, objetividade. É necessário agir. Quem sabe a revolta vira canção. 
O rap apresenta esse discurso da violência e criminalidade, mas, apesar das imagens agressivas e contraditórias, são as palavras que atuam como armas e, não raras vezes, apresentam um caminho alternativo, nem marginalidade, nem submissão, e, sim, criação ou religião.

Dayrell (2002) sintetiza o rap como uma produção poética, afirmando que:

\begin{abstract}
Nessa produção poética, a estrutura das letras, a fidelidade ao território e a explicitação de uma temática social são elementos identificadores do rap em qualquer lugar, seja no Brasil ou nos Estados Unidos. Ao mesmo tempo, o conteúdo poético tende a refletir o lugar social concreto onde cada jovem se situa e a forma como elabora suas vivências, numa postura de denúncia das condições em que vive: a violência, as drogas, o crime, a falta de perspectivas, quando sobreviver é o fio da navalha. Mas também cantam a amizade, o espaço onde moram, o desejo de um "mundo perfeito", a paz. [...] Nesse sentido, o rap pode ser visto como uma crônica da realidade da periferia (DAYRELL, 2002, p. 127).
\end{abstract}

A perspectiva apresentada por Dayrell dialoga com a abordagem do artigo de Roth-Gordon (2009), no qual a autora traça um paralelo entre o discurso presente no hip hop americano e o brasileiro, e comenta que, apesar da distância física e da diferença linguística, a juventude brasileira se conecta com o cenário do hip hop americano. E acrescenta,

Brazilian youth also forge connections to the United States by importing the Civil Rights-inspired rhetoric of North American politically conscious rap (Alim, 2006). As in the United States, young Black males are an increasingly endangered population in Brazil, the most likely targets of police brutality and the most frequent victims of the violence that surrounds drug trafficking (Huggins, 2000; Mitchel \& Wood, 1999; Scheper-Hughes \& Hoffman, 1994). They are commonly referred as marginais (marginals), a term that signifies poverty, social inferiority, and disenfranchisement, in addition to presumed criminality (Goldstein, 2004; González de la Rocha et al., 2004) (ROTHGORDON, 2009, p.65-66).

A conexão entre a temática apresentada pelos jovens brasileiros e americanos na produção artística ocorre não só em função da inspiração da retórica dos direitos civis, mas pelas suas vivências em sociedade.

Seria também a "criatividade" um dos elementos identificadores do rap, uma vez que ela pode tornar poesia uma temática social, às vezes tão devastadora e árdua? "Criatividade" se junta à "habilidade" e ao "improviso" no rap, e por meio dele os jovens expressam suas aspirações de uma vida melhor. Maneira de driblar os problemas, de optar por um caminho alternativo (nem ladrão, nem oprimido, mas 
artista, sobrevivente) e de conseguir algo que se configura como difícil à maioria das pessoas. Seria esse um caso de "jeitinho"?

\subsection{Favor}

(Seu garçom) Faça o favor de me trazer depressa ${ }^{61}$... Ser a favor de uma causa. Trabalhar em favor do povo. Por favor, não faça isso. Por favor é palavra mágica. Gentileza gera gentileza, porém, faça o favor de calar a boca...

O "favor" pode ser uma forma de "jeitinho": quando o sujeito se depara com uma situação na qual terá de fazer uso de suas relações pessoais para solucioná-la. Por exemplo, o sujeito conhece alguém que trabalha no posto de saúde e que possa interceder por ele, para diminuir ou derrubar obstáculos, ou simplesmente tornar o acesso fácil e rápido à solução de um problema, como adiantar um agendamento. $\mathrm{O}$ sujeito pode obter vantagem sem cometer infração. Em uma dessas situações, o "favor" pode se configurar como "jeitinho".

Eis como se dão as entradas nos dicionários.

No Aulete, encontramos "favor" como ajuda que se presta em caráter amistoso e generoso, geralmente sem se ter obrigação; benefício, proveito que se concede; graça, mercê; simpatia, agrado que se deseja obter ${ }^{62}$.

O Houaiss registra como o que se faz para alguém de graça, sem obrigação; obséquio; remissão de culpa concedida por indulgência; mercê, graça; vantagem, benefício que se concede a alguém; proveito; simpatia; consideração; vantagem devida à preferência que se recebe de alguém ou ao poder que se tem sobre alguém.

O "favor" apresenta algumas locuções registradas no Aulete: a favor de: favorável a. Em favor de: em benefício de, em prol de. Fazer (o) favor (de): expressão de cortesia em pedido. Por favor: expressão de cortesia ao pedir algo (favor, informação etc.).

Para abordar o tema do "favor", recorri à Pesquisa Social Brasileira ${ }^{63}$, PESB, empreendida pelo DataUff, Núcleo de Pesquisas, Informações e Políticas Públicas

\footnotetext{
${ }^{61}$ Conversa de botequim, de Noel Rosa.

${ }^{62}$ No caso de uma referência a conseguir favores de uma moça, tal ideia poderia remeter a favores sexuais ou afetivos, como em Noite de Verão, de Chico Buarque, em que o autor diz "... Que importa se esses beijos não são meus/Que só tenho essa noite de favor/Nos braços de uma atriz...”.
} 
da Universidade Federal Fluminense. As perguntas que compuseram a pesquisa foram elaboradas por Alberto Carlos Almeida, com a colaboração de Clifford Young. Foram realizadas 2.363 entrevistas, entre 18 de julho e 5 de outubro de 2002.

Uma das seções da pesquisa, sobre o "jeitinho brasileiro", permitiu avaliar a extensão do apoio social ao recurso, segundo Almeida (2007). Por meio de três perguntas, foi possível constatar o quanto ele está difundido na população. Nelas, o entrevistador questionou se alguma vez na vida o entrevistado já havia "dado um jeitinho para alguém", ou se já havia "pedido para alguém dar um jeitinho a seu favor", ou ainda, se já havia "dado um jeitinho". O autor pontua que "os resultados para as três perguntas são bastante homogêneos e coerentes: algo em torno de 2/3 de toda a população brasileira já se utilizou desse tipo de recurso" (ALMEIDA, 2007, p. 48).

Tendo como ponto de referência a escala sugerida por Barbosa (2006), a pesquisa quis saber: "na opinião do(a) senhor(a), o que é dar um jeitinho?". Em um segundo momento, solicita aos "entrevistados que classificassem 19 situações por meio de uma das seguintes denominações: Favor / Mais favor que jeitinho / Mais jeitinho do que favor / Jeitinho / Mais jeitinho do que corrupção / Mais corrupção do que jeitinho/ Corrupção" (ALMEIDA, 2007, p. 51).

Para a análise do "favor", nesse momento não farei uso de letra de canção, pois nenhuma outra canção pesquisada, além de Antonico, de Ismael Silva, que será analisada, a posteriori, em um dos estudos de caso, apresentou a palavra "favor" no contexto do âmbito da pesquisa.

Duas das quatro situações apresentadas com clareza como "favor" (de acordo com a PESB), que se referem à fila, serão analisadas inicialmente: na fila do supermercado, deixar passar na frente uma pessoa que tem poucas compras; e guardar o lugar na fila para alguém que vai resolver um problema.

\footnotetext{
${ }^{63} \mathrm{Na}$ elaboração da amostra, foram utilizados os dados da contagem de 1996 do IBGE e a divisão político-administrativa brasileira (cinco regiões, 26 estados mais o Distrito Federal e 5.507 municípios). A partir daí, foram sorteados 102 municípios e, desses, 27 foram considerados auto representativos (as capitais dos estados) e 75 não auto representativos. A amostra foi probabilística, com três estágios de seleção e representativa das cinco regiões. Para reduzir custos, todos os municípios com até 20.000 habitantes das regiões Norte e Centro-Oeste foram excluídos, o que significou que o equivalente a $3,1 \%$ da população ficou de fora da população amostrada (ALMEIDA, 2007, p.19).
} 
Fila é, segundo Houaiss, alinhamento de uma série de indivíduos ou objetos em sequência, de modo que um esteja imediatamente atrás do outro; fileira.

As situações apresentadas pela pesquisa mostram argumentos que são do âmbito do pessoal, que isolam quem os usa das outras pessoas na mesma situação. Esse é um problema da esfera privada. Por exemplo, alguém está na fila do supermercado e várias pessoas que têm um número de volumes pequeno pedem para passar à frente. A pessoa com o carrinho de compras não consegue sair do lugar. É uma situação que não leva em conta o/a prestador/a de serviço, sua eficiência. Envolve simplesmente a fila, uma sequência de pessoas que estão alinhadas, normalmente por ordem de chegada. A problematização do favor, como nuance do "jeitinho", surge, em alguns casos na sociedade brasileira, como um critério da "necessidade pessoal", como pontuou Barbosa (2007). Ainda, segundo a autora, "a primeira atitude de quem precisa de alguma coisa é declinar seus problemas de 'ordem pessoal', pois esses lhe darão precedência em relação a quem chegou primeiro" (BARBOSA, 2006, p.56).

Em uma sociedade anglo-saxã, não ocorreria facilmente a alguém pedir para passar à frente em uma fila por ter poucos volumes na sua compra. A sociedade americana atribui um peso diferente à igualdade. Barbosa acrescenta que a igualdade "se coloca como valor básico do sistema, porém como um pano de fundo a partir do qual a ação social deve se desenrolar, sendo o atributo da liberdade sistematicamente enfatizado nos diferentes níveis e domínios, pelos diferentes discursos" (BARBOSA, 2006, p.136). Dessa forma, se uma pessoa está na fila aguardando para passar a sua compra, não importa o número de volumes, ela não será importunada por outra, com pedido para passar à frente.

Existem outras situações, em que se pode identificar o "favor", e que não envolvem filas.

Como mencionado anteriormente, o "favor" se configura como uma situação em que à maioria das pessoas vai implicar reciprocidade. Existe uma situação de hierarquia na qual a pessoa que presta o favor está em situação superior a quem o pede, e se estabelece uma relação de credor e devedor entre esses pares. Normalmente, há um grau de conhecimento entre as pessoas envolvidas na situação, pois "existe a ideia de que determinados assuntos e situações requerem 
confiança por parte de quem pede e, portanto, é necessário conhecer com quem se está tratando" (BARBOSA, 2006, p. 43).

O "favor" está relacionado à ideia de não haver transgressão de normas ou regras preestabelecidas, que é o aspecto que o diferencia do "jeitinho". Porém, esta rigidez na distinção nem sempre fica evidente. Por exemplo, posso pedir para alguém "dar um jeitinho" e não infringir regra alguma, ao passo que posso "pedir um favor" que pode resultar em uma infração à lei. São os meandros que cercam o continuum entre "favor" e "corrupção".

\subsection{Corrupção}

Corrupção... (...). Sem comentários.

Assim como o "favor" é uma forma de "jeito" valorizado positivamente, a "corrupção" revela o seu lado negativo. A distinção entre eles não se configura como uma linha clara e estanque. Para grande parte das pessoas, o que parece distinguir um do outro é o fato de haver alguma vantagem material envolvida na situação. Até que ponto, oferecer ou aceitar "um cafezinho", "uma cervejinha" ou "algum por fora", pode ser considerado "corrupção" ou só um "jeitinho"?

No Aulete encontramos corrupção como ação ou resultado de corromper(-se); adulteração das características originais de algo; desvirtuação; deturpação; sociologia: ato ou efeito de subornar, vender e comprar vantagens, desviar recursos, fraudar, furtar em benefício próprio e em prejuízo do Estado ou do bem público; aliciação; figurado: degeneração moral; depravação; imoralidade; perversão.

O Houaiss registra o vocábulo como deterioração, decomposição física de algo; putrefação; modificação, adulteração das características originais de algo; derivação: sentido figurado: depravação de hábitos, costumes etc.; devassidão; ato ou efeito de subornar uma ou mais pessoas em causa própria ou alheia, geralmente com oferecimento de dinheiro; suborno; uso de meios ilegais para apropriar-se de informações privilegiadas, em benefício próprio.

Pega Ladrão ${ }^{64}$ e Rap do Mensalão ${ }^{65}$, ambos de Gabriel O Pensador, são as letras de canções utilizadas para ilustrar a discussão sobre o vocábulo. Ladrão de

\footnotetext{
64 Disponível em: <http://letras.mus.br/gabriel-pensador/73483/>. Acesso em: 26 dez. 2012.

65 Disponível em: <http://letras.mus.br/gabriel-pensador/311657/>. Acesso em: 26 dez. 2012.
} 
Gravata vem na sequência, pois estaria no mesmo contexto, porém, sua análise é feita posteriormente.

- Vossa Excelência, agora explique, mas não complique!

- Vossa Excelência, eu já expliquei! Eu não vi essa lista.

Eu afirmo com a mais absoluta certeza e sinceridade

Que eu nunca vi essa lista!

Não sei dessa lista, não quero saber e tenho raiva de quem sabe!

Quem disser que eu vi essa lista é um mentiroso,

E vai ter que provar! E se provar, vai se ver comigo!"

Pega ladrão! No Governo!

Pega ladrão! No Congresso!

Pega ladrão! No Senado!

Pega lá na Câmara dos Deputados!

Pega ladrão! No Palanque!

Pega ladrão! No Tribunal!

É por causa desses caras

Que tem gente com fome

Que tem gente matando

A miséria só existe porque tem corrupção!

Tira do Poder, Bota na prisão!

E você que é um simples mortal

Levando uma vidinha legal

Alguém já te pediu 1 real?

Alguém já te assaltou no sinal?

Você acha que as coisas vão mal?

Ou você tá satisfeito?

Você acha que isso é tudo normal?

Você acha que o país não tem jeito?

Aqui não tem terremoto

Aqui não tem vulcão

Aqui tem tempo bom

Aqui tem muito chão

Aqui tem gente boa

Aqui tem gente honesta

Mas no poder é que tem gente que não presta

"Eu fui eleito e represento o povo brasileiro.

Confie em mim que eu tomo conta do dinheiro."

...

A miséria só existe porque tem corrupção!

Tira do Poder, Bota na prisão!

Tira esse malando do poder executivo!

Tira esse malandro do poder judiciário!

Tira esse malandro do poder legislativo!

Tira do poder que eu já cansei de ser otário!

Tira esse malandro do poder municipal!

Tira esse malandro do governo estadual!

Tira esse malandro do governo federal!

Tira a grana deles e aumenta o meu salário!

- Tá vendo essa mansão sensacional?

Comprei com o dinheiro desviado do hospital.

- Ah! E o meu cofre cheio de dólar? 
É o dinheiro que seria pra fazer mais uma escola.

- Precisa ver minha fazenda! Comprei só com o dinheiro da merenda!

- E o meu filhão? Um milhão só de mesada!

E tudo com o dinheiro das crianças abandonadas.

- E a minha esposa não me leva à falência

Porque eu tapo esse buraco com o rombo da Previdência.

- Vossa excelência, cê não viu meu avião?

Comprei com uma verba que era pra construir prisão!

- E a superlotação?

- Problema do povão! Não temos imunidade? Pra nós não pega não."

Pega, pega!

A miséria só existe porque tem corrupção!

Tira do Poder, Bota na prisão!

A miséria só existe porque tem corrupção

Desemprego só aumenta porque tem corrupção

Violência só explode porque tem tanta miséria e desemprego

Porque tem tanta corrupção!

"Todos que me conhecem sabem muito bem que eu não admito

O enriquecimento do pobre e o empobrecimento do rico."

E você, que nasceu nesse país

E que sonha e que sua pra ser feliz

Você presta atenção no que o candidato diz?

Ou cê vota em qualquer um, seu babaca?

E depois da eleição você cobra resultado?

Ou fica ai parado de braço cruzado?

Cê lembra em quem votou pra deputado?

E quem você botou lá no Senado?

A miséria só existe porque tem corrupção!

$\cdots$

\section{Rap do Mensalão}

A política no país é pura decepção, um escândalo abafa o outro e ninguém vai pra

prisão e a onda do momento é o maldito mensalão.

Estou vivendo estressado, quase louco alucinado, pego duro no batente e todo mês

eu sou roubado.

A poluição detona minha cabeça, e antes que eu me esqueça, viva a vida e não pereça.

O mundo hoje em dia tá todo na contra mão, só se fala em guerra, fome e nesta tal

Corrupção, êpa onde está o ladrão?

\section{Ladrão de gravata}

Cata, o cara é ladrão de gravata

só vive atrás de mamata

achando que aqui tem babaca

intriga, "k-ô", armação

troca de favor, mentira, corrupção

depois aparece na televisão

com a cara lavada dizendo que não

A culpa é sua mané, que colocou ele lá agora sabe qual é? 
você vai ter que aturar, mas se você percebeu

que ele roubou de você

então faça como eu: eu vou virar, vou vencer

Eu quero ver, eu quero ver

eu vou virar, vou vencer

Eu quero ver, eu quero ver

Vai se foder então

Cata, o cara é ladrão de gravata

só vive atrás de mamata

achando que aqui tem babaca

- aí tem uma parada aí que acho vai rolar uma sobra de uma grana boa meu

irmão

- quantos porcento?

- a sei lá, $60 \%$

$-60 \%$ pra quem?

- é vamo dividir né

- 30 a 30 ?

-30 a 30

- ou 60 pra mim?

- 30 não eu gostaria de roubar tudo, mas...

- acho que você não vai roubar tudo sozinho não, porque eu não vou deixar

A corrupção pode ser detectada em vários segmentos da sociedade, mas nos exemplos mencionados, assim como ao menor exame das notícias nas diversas mídias, pode-se constatar, ela é associada ao Estado e à política. Não escapa ileso nenhum dos poderes e nenhum nível de governo. O sujeito que está na vida pública teria de primar pela lisura para não ser colocado na vala comum dos corruptos. Agindo em deslisura, alimenta a desconfiança e engrossa o conjunto dos mentirosos, ladrões, malandros. Desvia dinheiro da saúde, da merenda e causa o rombo da previdência. Tem mansão, fazenda e avião. Tudo isso adquirido após seu ingresso na vida pública. Agarra-se ao corporativismo como tábua de salvação, pois se um deles for desmascarado, outros correm o risco de cair. É a tática do "ninguém sabe, ninguém viu". Como todos são inocentes até que se prove o contrário, manobras são feitas à custa de brechas na lei; nunca se consegue comprovar nada contra ninguém. A corrupção é responsável pela miséria e desemprego, e o sujeito homem público é colocado como responsável pela situação, como se ele se tornasse corrupto sem necessidade de corruptores, como se a dinâmica de corrupção não exigisse um polo corruptor e um polo corrupto. Além de tudo, ele é o sujeito que questiona o sujeito eleitor, pois se é o eleitor quem tem o poder de mudar a situação com o seu voto, porque continua a perpetuar essas pessoas no poder?

Em Pega Ladrão, o sujeito destaca o fato de o país não sofrer com algumas catástrofes naturais, mas isso seria o suficiente? Como pode o sujeito se sentir 
satisfeito, não ter outras aspirações, achar que tudo é normal, e pensar que o país não tem jeito por causa da atuação dos políticos?

Com a análise do vocábulo feita até o momento, associada às suas definições, torna-se difícil considerar "corrupção" como "jeitinho".

Se o ato da "corrupção" é visto como o que resulta em certa vantagem material, por que, ainda assim, suscita dúvidas? Talvez porque algumas pessoas consideram que pagar "uma cerveja" ou "um cafezinho" ao guarda para não serem multadas, seja visto como "jeito". Justificam com o argumento de que o montante de dinheiro envolvido é baixo, e que normalmente envolve muito "papo".

Quando se analisa um caso sob a ótica do "jeito", deve-se verificar o contexto. Situá-lo como favor ou corrupção vai depender do tipo de discurso que o sujeito ativa.

Segundo Barbosa (2006), para as pessoas que apresentam um discurso condenatório do "jeito", "o montante do dinheiro pesa, mas não é critério absoluto; a transgressão da norma e a pouca credibilidade institucional que a prática do jeito acarreta são consideradas fundamentais" (BARBOSA, 2006, p. 44).

Apesar de ser difícil distinguir o "jeito" da "corrupção", sabe-se que "jeitinho demais leva à corrupção". Esta consciência é demonstrada, por exemplo, pelas pessoas entrevistadas ${ }^{66}$ por Barbosa (2006), por ocasião da elaboração de sua tese de doutorado, no Programa de Pós-Graduação em Antropologia Social (PPGAS), do Museu Nacional da Universidade Federal do Rio de Janeiro.

Nessa pesquisa, a autora pontua que, para reconhecer que o "jeitinho" extrapolou para a "corrupção", devem ser considerados o contexto, tipos de discurso e qual o numerário envolvido.

Ainda, em um levantamento rápido das acepções apresentadas acima para o vocábulo "corrupção", há: desvirtuação, deturpação, degeneração moral, depravação de hábitos, imoralidade, perversão, deterioração, decomposição, putrefação, devassidão, aliciação, suborno, só para apresentar algumas. Figurativização extremamente negativa! Será isso "jeito"? Ou consequência do "jeito"? Ou não se relacionam?

\footnotetext{
${ }^{66}$ Pesquisa empírica com duzentas pessoas, de diferentes cidades como Recife, Rio de Janeiro, João Pessoa, Porto Alegre, [...], no período de 1984 a 1986 (BARBOSA, 2006, p. 40).
} 
Em Ladrão de gravata $^{67}$, composição de Tico Santa Cruz e Tiago Mocotó, as seguintes estrofes foram analisadas: "A culpa é sua mané, que colocou ele lálagora sabe qual é?/você vai ter que aturar, mas se você percebeu/que ele roubou de você/então faça como eu: eu vou virar, vou vencer".

Aqui, a denúncia não é figurativizada no sistema propriamente. Há o corrupto, e a culpa pelo que ele faz é cobrada de quem lhe delegou poderes, o mané, que em última instância é o povo, é o eleitor, no caso do engravatado ser homem público, alçado ao cargo pelo voto. E o que ele, o eleitor, pode fazer? Pode dar a resposta, "pode virar, pode vencer", que seria o voto consciente. Mas tem o reverso da moeda: e se ao seu lado o "engravatado" tiver um adepto da "Lei de Gérson", que gosta de levar vantagem, ou então, o sujeito tem como conduta e lema o fato de que "se todos estão tirando proveito, por que eu vou ficar de fora?" Aqui, há o corrupto e o corruptor, dando um jeito de tirar mais. "-aí tem uma parada aí que acho vai rolar uma sobra de uma grana boa meu irmão/- quantos por cento?/- a sei lá, 60\%/- 60\% pra quem?/- é vamo dividir né/ - 30 a 30?/- 30 a 30/- ou 60 pra mim?/- 30 não eu gostaria de roubar tudo, mas.../- acho que você não vai roubar tudo sozinho não, porque eu não vou deixar".

Por que a corrupção também é pensada como "jeitinho"?

O continuum no qual se encontra o "jeito", em uma zona nebulosa entre o favor e a corrupção, principalmente quando tende para o seu lado mais negativo, suscita questão como a apontada por Almeida (2010), por ocasião da realização da PESB: por que a cultura da corrupção é tão arraigada entre nós?

\begin{abstract}
... isso acontece porque a corrupção não é simplesmente a obra perversa de nossos políticos e governantes. Sob a simpática expressão "jeitinho brasileiro", ela é socialmente aceita, conta com o apoio da população, que a encara como tolerável.

Numa interpretação complacente, o jeitinho é sempre o instrumento que possibilita a quebra de regras. Sejam boas ou ruins, por definição elas são universais e se aplicam a todos os cidadãos. Se forem injustas ou ilegítimas, devem ser mudadas. Porém, uma vez estabelecidas, devem e precisam ser seguidas (ALMEIDA, 2010, p.45).
\end{abstract}

De fato, as leis devem ser seguidas. No entanto, pergunto: as leis no nosso país são analisadas ou avaliadas em um grau necessário para que se possa dizer

${ }^{67}$ Disponível em: <http://letras.mus.br/detonautas/68411/>. Acesso em: 26 dez. 2012. 
com certeza que elas não são justas ou legítimas? E se assim forem avaliadas, testemunhamos alguma mudança? Se não, o uso do jeitinho é justificável?

\subsection{Flexibilidade moral}

O que seria "flexibilidade moral"? Seria a disposição de fazer o que for necessário para alcançar o que se almeja, tanto no campo profissional, político, econômico ou no âmbito social, e compreenderia omissões voluntárias, inverdades e mentiras em diferentes graus?

Quando me deparei com a expressão "flexibilidade moral", além de ser improvável encontrar tal expressão em letra de canção, julguei que havia a necessidade de discutir uma situação mais ampla, um caso. Talvez pela complexidade ou pela importância que a expressão assume quando estabelece uma relação entre o jeitinho e a corrupção. Ela esclarece a possibilidade de um ato de “jeito" se transformar em "corrupção".

Apresento um caso que fez parte de uma série de reportagens do Jornal da Record, O Brasil do jeitinho. O caso abordado foi ao ar na edição do dia 25 de agosto de 2011, com apresentação de Ana Paula Padrão e Celso Freitas, e em campo, o repórter Jésus Mosquera. A intenção (da reportagem) foi de mostrar a reação das pessoas a pequenos testes de honestidade. A transcrição ${ }^{68}$ de trecho da reportagem consta em nota de rodapé.

${ }^{68}$ Celso Freitas: O taxista que faz o caminho mais longo; o técnico que cobra a mais para fazer um simples conserto; o motorista que usa o acostamento. Por que que há tanta gente que quer levar vantagem em tudo, hein?

Ana Paula Padrão: O Jornal da Record foi às ruas para fazer um teste de honestidade. E observou como o brasileiro age quando recebe, por exemplo, um troco a mais. O resultado você acompanha agora na série $O$ Brasil do jeitinho.

Repórter (narração): Um país onde levar vantagem em tudo é o lema de muita gente... Honestidade é uma virtude rara? [...] Como somos no dia-a-dia, no supermercado, na padaria, no táxi e até em casa? Somos enganados ou enganamos? [...]

Durante duas semanas conversamos com pessoas comuns e testemunhamos como elas reagem a pequenos testes de honestidade. Levar para casa um troco a mais, da padaria ou do mercadinho. Cobrar a mais pelo conserto de um eletrodoméstico. Enganar um turista numa corrida de táxi, para aumentar o faturamento. Por que essas atitudes são tão toleradas por nós?

Repórter (narração): 10 da manhã. Estamos numa padaria no centro de São Paulo e colocamos uma câmera sobre o caixa. A atendente foi instruída por nossa equipe a dar dez reais a mais de troco para alguns clientes. O cidadão comum devolve o dinheiro ou leva para casa?

Repórter: A gente tem anotado aqui os números de série das duas notas de dez reais que estão lá dentro. Quero ver o que vai dar!

Preste atenção nesta mulher. O valor da compra dela é de $R \$ 5,40$. Ela dá $R \$ 7,00$. Deveria receber $R \$ 1,60$ de troco. Mas, além das moedas, leva embora mais uma nota de $R \$ 10,00$. 
Enquanto realizava a busca por um caso que retratasse o tema, fiz uma constatação: na maior parte dos casos registrados em vídeos, o "jeitinho" é mostrado como "levar vantagem" em relação a ficar com uma carteira que se acha, mesmo tendo a identificação do dono ("achado não é roubado, quem perdeu foi relaxado"); ficar com o troco que recebe a mais, sabendo que ao final do dia, a diferença normalmente será cobrada do funcionário etc.

Por que chamar esses deslizes de caráter de "jeitinho"? Este não seria um típico caso que poderia ser identificado como "flexibilidade moral"?

O desenrolar da ação ocorre da seguinte forma: o repórter entrega duas notas de $R \$ 10,00$ à caixa de uma padaria e pede a ela que entregue troco a mais a alguns clientes. Quando uma mulher paga a sua conta de $R \$ 5,40$ com $R \$ 7,00$, a atendente devolve $R \$ 11,50$ quando deveria ter sido $R \$ 1,60$. À saída do estabelecimento é questionada pelo repórter em relação ao troco que recebeu; ela diz que foi $R \$ 1,50$, e retorna para cobrar os $R \$ 0,10$ da atendente. O repórter pergunta (em off) se ela não viu que tinha recebido os $R \$ 10,00$ a mais. Ao sair novamente do estabelecimento, o repórter pede à mulher para conferir o troco. Ela diz que já misturou com outro dinheiro, mas atende ao pedido do repórter. Quando o repórter confere e diz que a nota não the pertence, a reação da mulher é de perplexidade. Ou seria um riso de nervosismo e vergonha?

Repórter (conversando com a mulher): O troco deveria ser $\mathrm{R} \$ 1,60$.

Mulher: Veio $\mathrm{R} \$ 1,50$.

Repórter: Veio $\mathrm{R} \$ 1,50$ ? Posso dar uma olhadinha?

Mulher: Agora já misturei como resto, mas pode.

A mulher voltou para cobrar os dez centavos que estavam faltando. Mas será que não notou que levou $\mathrm{R} \$ 10,00$ a mais?

Repórter: Posso dar uma olhadinha nessa notinha de $\mathrm{R} \$ 10,00$ ? Vamos ver se ela bate com a que a gente tem anotado aqui.

Mulher: Já pensou se eu fui premiada? (Risos)

Repórter: Já pensou? Peraí... Olha, E7100084225... Essa nota não pertence à senhora.

Mulher: Não? De quem é?

Repórter: É da padaria. Veio $\mathrm{R} \$ 10$ a mais no troco da senhora.

Mulher: A mais?

A mulher retorna à padaria, fala com a atendente: (você) me deu $R \$ 0,10$ a menos e eu vi que faltava... eu não vi que você me devolveu $R \$ 10,00$ a mais.

Atendente: Ah, tá! Desculpa!

Mulher: Eu é que peço desculpas, tá... Obrigada!

Distração???

[...]

Disponível em: <https://www.youtube.com/watch?v=cavlBfpFkHw>. Acesso em: 22 jun. 2014. 
Não há certeza. Porém, vou analisar esse caso sob a perspectiva de que a mulher havia percebido o erro e ficou com o troco a mais, conscientemente. Peço essa licença para realizar a análise.

Fazer o que for necessário para obter alguma vantagem em uma dada situação; ser capaz de algo imoral; ficar com algo que não lhe pertença, constituem a flexibilidade moral, que poderia ser definida como uma justificativa para atos impróprios, porém conscientes e avaliados.

Diante do caso apresentado, o fato da pessoa se apropriar de numerário, que não lhe pertença, independentemente do valor, torna a "flexibilidade moral" um caminho que leva à trilha da corrupção.

\subsection{Quanto jeito!!!}

Algumas observações em relação ao grupo de palavras associadas a "jeito" são necessárias.

São palavras que identificam o "jeito" ou "jeitinho" em sua forma mais relativa à "criatividade", às "habilidades" e aos recursos que as pessoas dispõem para a resolução de problemas, ao "improviso" de se resolver algo da maneira que for possível. Até uma gambiarra resolve. A "flexibilidade", o "jogo de cintura", a "ginga", a "dança conforme a música", o modo de tornar as dificuldades mais leves e suportáveis. Todas essas formas aparecem mais relacionadas a um "jeitinho criativo", e não dependem, necessariamente, de envolver um ato ilícito ou driblar questões burocráticas, que são encaradas como agir em não conformidade com as leis.

Outro ponto que chamou a atenção em relação à pesquisa das letras das canções foi o fato de ser mais difícil a ocorrência desses vocábulos. Registros raros, mas aconteceram.

Habilidade, criatividade, flexibilidade, improviso, favor e corrupção são vocábulos que foram registrados em algumas letras de rap na pesquisa por mim realizada. Existem várias vertentes de rap, com estilos diversos. Grande parte aborda temática mais relacionada à periferia e ao seu modo de vida, ao sistema, à polícia, à violência, à questão social. Cantam a denúncia da violência policial, da discriminação racial contra os negros, do seu histórico de lutas, do orgulho de sua 
origem cultural. Às vezes, letras de forte apelo religioso. Quanto às letras de Gabriel O Pensador - talvez por não apresentar história de vida em nada similar a dos rappers em geral -, retratam certa indignação com a conjuntura do país, o sistema político e apresentam um tom de denúncia do cidadão em geral, de quem quer que as pessoas se conscientizem e mudem suas posturas, suas escolhas. Essa indignação também está presente nas composições dos rappers que tiveram sua origem na periferia, com a observação de que pensam mais na sobrevivência, em seu grupo social, e quando se referem à sociedade em geral, normalmente o fazem no sentido de alerta em relação à postura assumida perante "eles", em tom de cobrança. Como uma luta entre os pobres e ricos, entre o bem e o mal, a favor das minorias, dos oprimidos, contra a imposição de ideias e de atitudes.

Em relação ao elemento de identidade nacional, aceitar a tolerância ao dito modo de ser brasileiro não seria uma forma de permitir que a cidadania fosse "comprometida", não proporcionando condições para que os sujeitos questionem o mecanismo do "jeitinho"?

Afinal, quantos jeitos!! 


\section{JEITO, JEITINHO, JEITINHO BRASILEIRO, BRAZILIAN (LITTLE)}

Com o objetivo de estudar o campo semântico e discursivo do vocábulo "jeitinho" e de seus parassinônimos, a minha escolha incidiu sobre o estudo de textos que ilustram diferentes situações de ocorrência e os efeitos de sentido que cada exemplo propicia. Esses textos, nos quais pude identificar as variações do "jeitinho", oferecem alternativas ao eixo proposto por Barbosa (2006).

Quando iniciei o trabalho de pesquisa, percebi que a maioria dos estudos sobre o assunto do "jeitinho" utilizam Barbosa (2006) como fonte de informações, dada a competência, a abrangência e dedicação da autora, apesar de Roberto DaMatta ter sido o precursor como estudioso do tema e seu ferrenho porta-voz.

Os trabalhos que se seguiram, nas mais diversas áreas, utilizam as definições da autora e, principalmente, sua sugestão de configuração, utilizando um gráfico para ilustrar a variação do continuum em que está o "jeitinho", entre o favor e a corrupção.

Essa é a representação proposta por Barbosa e que apresento novamente:
$(+)$
$(+) /(-)$

$(-)$

favor

jeito

corrupção

Barbosa (2006) pontua que essa representação gráfica foi resultado de tentativa de definir o "jeito" de forma mais ou menos objetiva, e que as respostas dos sujeitos não permitem traçar as categorias de maneira nítida. E acrescenta:

O que é e o que não é jeito variam bastante. Não existe um elemento sequer que pudéssemos assinalar cuja presença configuraria uma situação que fosse definida por todos como jeito. Sabemos que jeito se distingue de outras categorias afins no universo social brasileiro como favor e corrupção. Entretanto, é difícil estabelecer o que distingue o jeito do favor ou da corrupção. Sabemos, por várias entrevistas, que "jeitinho demais leva à corrupção" e que "não peço favor a qualquer um", embora não seja necessário se conhecer alguém para se pedir um jeito. Mas onde, 
nitidamente, começa um e termina o outro é difícil de precisar (BARBOSA, 2006, p. 41-42).

Ainda, segundo a autora, o continuum é uma forma de entender melhor essas categorias e se estende de um polo, considerado positivo pela sociedade, que é o favor, até o outro extremo, visto de maneira negativa, que é a corrupção e, no meio o jeito, que tanto pode ser visto de uma perspectiva positiva como negativa. Barbosa (2006) declara que "o que caracteriza a passagem de uma categoria para outra é muito mais o contexto em que a situação ocorre e o tipo de relação existente entre as pessoas envolvidas do que, propriamente, uma natureza peculiar a cada uma" (BARBOSA, 2006, p. 42).

$\mathrm{Na}$ leitura de diversos trabalhos que se seguiram a Barbosa (2006), identifiquei que várias das definições, e adendos a elas, reafirmaram alguma característica do "jeitinho". E somado aos estudos lexicais, observei que esse continuum poderia ser mais amplo, contendo, ainda, informações fornecidas por outros pesquisadores. Não que os limites ficassem claros, absolutamente, mas as identificações poderiam ser facilitadas.

DaMatta acrescenta a uma das definições do "jeitinho" que se trata de um "modo simpático" de se chegar a uma solução; segundo Campos, estaria mais para uma "condição de sobrevivência do indivíduo"; para Guerreiro Ramos, o jeitinho é "realista, flexível, pragmático"; já para Oliveira Torres, "o jeito se traduz na capacidade de adaptação"; para Rosenn, o "jeitinho" remete a uma gama de qualificações, tais como "instituição tão intimamente ligada à corrupção" ou "sentimentalismo", "complexo de coitado", "simpatia", "compaixão", "paternalista", "personalista", ou ainda "integração social e cooperação comunitária", até mesmo "fragilidade humana"; para Abreu, é um "instrumento de poder", além de ser maneira "criativa" de agir; apenas para citar os precursores ou contemporâneos de Barbosa que pesquisaram o tema. Entre os que estenderam a pesquisa, a partir de Barbosa, saliento os pontos de vista de Borges (2006), segundo quem o "jeitinho" envolve sempre "solidariedade"; e de Souza (2008), que destaca a "flexibilidade".

Portanto, a contribuição para ampliar e detalhar o campo semântico do "jeitinho" foi possível por meio de pesquisas nas áreas da Linguística, Sociologia e Antropologia, História, Ciências Políticas, Psicologia, Administração, Teologia, 
Comunicações. A mim, coube a síntese das diferentes ocorrências para apresentar um modelo discursivo mais detalhado.

Neste capítulo, primeiramente utilizo o continuum de Barbosa (2006). Contudo, por meio dos textos, procuro ampliar as categorias reconhecidas, em geral, como sendo "jeito", nomeando-as de outra maneira, por seus parassinônimos: solidariedade, sobrevivência, criatividade, habilidade, flexibilidade, simpatia e charme, improviso, arranjo, hipocrisia, "flexibilidade moral"69.

Em segundo lugar, discuto a maneira como o "jeitinho brasileiro" é recebido e percebido pelo estrangeiro falante de língua inglesa, a partir das formas como é apresentado no contexto da língua inglesa, como se dá sua apreensão pelo estrangeiro, a grande gama de traduções para ele que são encontradas em inglês, até mesmo a opção pela não tradução.

\subsection{Antonico, me faz um favor...}

O texto com que inicio alude ao "favor", e é uma canção de Ismael Silva, Antonico $^{70}$, de 1950. O compositor, nascido em Niterói, em 14 de setembro de 1905, teve um a infância pobre. Morreu em 14 de março de 1978, na cidade do Rio de Janeiro. Sambista precoce, Ismael era um apaixonado pela boemia, bares, jogo, música, e pelo terno de linho branco, um ícone do samba e da elegância da malandragem.

Ismael, juntamente com outros bambas do samba, formou o bloco Deixa falar, durante o carnaval, nos anos 20, no bairro do Estácio, que daria origem à primeira escola de samba. Com o passar do tempo, o compositor, que vivia sem dinheiro, não tinha meios para assistir ao desfile das escolas. Certa ocasião, teria declarado: "Sou sambista; quer dizer, sou pobre. Tive que me virar e pedir a todo mundo para dar um jeito de eu ir à Presidente Vargas" (grifo nosso), escreve Eliete Negreiros, no blog da Revista Piaui ${ }^{71}$, em artigo dedicado ao compositor, sob o título $O$ grande Ismael Silva.

\footnotetext{
${ }^{69}$ O tema da "flexibilidade moral" é retomado na página 126, e está presente na obra de Maquiavel, $O$ príncipe.

70 Disponível em: < http://letras.mus.br/ismael-silva/389201/>. Acesso em: 26 dez. 2012.

${ }^{71}$ Disponível em: <http://revistapiaui.estadao.com.br/blogs/questoes-musicais/geral/o-grande-ismaelsilva>. Acesso em: 16 mar. 2014.
} 
Negreiros acrescenta que foi em um show de Gal Costa, de 1971, que ouviu, atônita, Gal cantar o que ela considera uma das mais belas canções brasileiras, Antonico. Comenta, ainda, que a canção é "diferente dos sambas ritmados, uma canção lenta, um apelo à amizade, à solidariedade, uma canção compassiva" (NEGREIROS, 2012). Eis a letra da canção:

\author{
Ôh Antonico \\ Vou the pedir um favor \\ Que só depende da sua boa vontade \\ É necessário uma viração pro Nestor \\ Que está vivendo em grande dificuldade \\ Ele está mesmo dançando na corda bamba \\ Ele é aquele que na escola de samba \\ Toca cuíca, toca surdo e tamborim \\ Faça por ele como se fosse por mim \\ Até muamba ${ }^{72}$ já fizeram pro rapaz \\ Porque no samba ninguém faz o que ele faz \\ Mas hei de vê-lo muito bem \\ Se Deus quiser \\ E agradeço pelo que você fizer
}

O sujeito em questão pede um favor a Antonico. Não para si, mas para um amigo, que está em dificuldade. Esse amigo, Nestor, está dançando na corda bamba, vivendo uma situação difícil. O favor só depende da boa vontade de Antonico. A "viração" de que Nestor precisa, é uma ocupação, ou um serviço eventual, de curta duração, um bico, um biscate, segundo Houaiss. Nestor pode retribuir, pois possui vários atributos que podem interessar. Ele é bom de samba, toca vários instrumentos. Na tentativa de ajudá-lo, por ser uma pessoa com dotes bastante apreciados no samba, já fizeram até despacho, feitiçaria. O pedido demonstra como Nestor é caro ao sujeito, tanto que, "faça por ele como se fosse por mim", é um pedido que transfere a responsabilidade de pagar o favor para quem o pede (o sujeito) e não para quem o está recebendo (Nestor).

O espetáculo está descrito. Os participantes são: o amigo do Antonico, que estabelece toda a narrativa e pede o favor (passarei a denominá-lo Amigo); Antonico, que dispõe de condição para operar as mudanças, e pode fazer o favor; e o Nestor, que se beneficiará se o que for proposto se realizar.

Antonico é o sujeito que sabe fazer e pode fazer as transformações. O sujeito Nestor está em disjunção com o objeto valor (Ov) emprego. Só que Nestor não tem

\footnotetext{
${ }^{72}$ Muamba: no candomblé e na umbanda, feitiço ('bruxedo'), segundo Houaiss.
} 
como estabelecer relação com Antonico. Então, o sujeito Amigo recorre a Antonico, utiliza-se da amizade que existe entre eles, para que Antonico seja capaz de transformar o estado de Nestor. Ocorre uma manipulação por sedução da parte do Amigo, no sentido de fazer com que Antonico queira fazer o que o Amigo pede. E o querer fazer de Antonico vai ocorrer se ele realmente prezar a amizade do Amigo, pois a sedução envolve tão somente o agradecimento e a manutenção do alto conceito que Antonico tem aos olhos do Amigo.

O Amigo procura garantir a manipulação, valorizando os dotes de Nestor, que é importante na escola de samba - toca cuíca, surdo e tamborim. O que ele faz, ninguém mais faz. Assim, o que o Antonico fizer, será um favor para o Amigo e para a escola. Ocorre, ainda, manifestação para que a manipulação seja aceita, com a assunção de que o sujeito Amigo há de ver Nestor bem feliz, se Deus quiser!

O restante do percurso, com a performance e a sanção, não se instalam. O que coube ao Amigo, foi apelar para Deus. E contar que sua amizade seja cara ao Antonico.

No que se refere ao nível discursivo, é um texto em que se destacam os seguintes temas:

- Trabalho, emprego, desemprego, dificuldade financeira.

- Amizade, solidariedade, compreensão e compaixão.

- Samba, escola de samba.

Em relação às figuras, há a corda bamba, a escola de samba, a cuíca, o surdo, o tamborim, e a muamba.

As pessoas são o Amigo, Antonico e Nestor, no espaço do Rio de Janeiro (pressuposto), ambientado, provavelmente, junto à escola de samba, por volta dos anos 50. O narrador, eu, Amigo, dirige-se a Antonico, o tu. O espaço é o aqui, que é o espaço do eu, e o tempo é o agora.

Para a análise desta canção, é importante verificar como o "favor" torna-se um componente importante historicamente na sociedade brasileira. Segundo Schwarz (2012),

Pode-se dizer que a colonização produziu, com base no monopólio da terra, três classes de população: o latifundiário, o escravo e o 'homem livre', na verdade dependente. Entre os primeiros dois a relação é clara, é a multidão dos terceiros que nos interessa. Nem os proprietários nem proletários, seu 
acesso à vida social e a seus bens depende materialmente do favor, indireto ou direto, de um grande. [...] O favor é, portanto, o mecanismo através do qual se reproduz uma das grandes classes da sociedade, envolvendo também a outra, a dos que têm (SCHWARZ, 2012, p. 15).

O "favor" expôs uma dependência, a opção para a sobrevivência da maioria da população, em um determinado período da nossa história. Porém, esse elemento ocorria apenas no eixo vertical, hierárquico, de cima para baixo, com o superior (o que tem) proporcionando condições de subsistência e criando um vínculo que implicaria, algumas vezes, em fidelidade e subserviência daquele que dele se beneficiaria.

Isso perdurou em um determinado período na história, enquanto "o profissional dependia do favor para o exercício de sua profissão, o pequeno proprietário dependia dele para a segurança de sua propriedade, e o funcionário para o seu posto" (SCHWARZ, 2012, p. 16). O "favor" era utilizado para a mediação de casos, e garantia certa cumplicidade entre as partes.

Há, porém, outra forma de o "favor" ser compreendido, não somente em seu eixo vertical de um só sentido. Não há apenas a relação de subserviência ou de obrigação de lealdade no "favor". Desenvolve-se entre as partes envolvidas uma relação mútua, independentemente de qualquer relação de poder. Barbosa (2006), declara: "sabemos pela nossa etnografia que essa categoria pressupõe uma equivalência moral entre as pessoas e postula uma relação de reciprocidade entre elas independentemente da posição social que ocupam" (p. 59).

Pode-se dizer que, nas sociedades ocidentais, de forma geral, quando alguém faz um "favor", espera uma retribuição, não necessariamente da mesma ordem, nem de imediato, mas existe um desejo de que, de alguma forma, aquilo seja "pago". Neste sentido, o favor poderia corresponder à "dádiva" da sociologia de Marcel Mauss ${ }^{73}$, em que no dar-receber-retribuir, "o bem devolvido nunca tem o valor igual àquele do bem inicialmente recebido. [...] Mas esse presente ou hospitalidade pode ser retribuído num outro momento mediante uma gentileza ou favor, fazendo circular a roda das práticas sociais e das experiências de vida dos envolvidos" (MARTINS, 2005, p. 54).

\footnotetext{
${ }^{73}$ Marcel Mauss, antropólogo e etnólogo. Principal sistematizador da teoria da dádiva, que vem sendo resgatada como modelo interpretativo de grande atualidade para se pensar os fundamentos da solidariedade e da aliança nas sociedades contemporâneas (MARTINS, 2005, p. 45).
} 
Em sua acepção dicionarizável, "favor" tanto pode ser "o que se faz para alguém de graça, sem obrigação ou obséquio", quanto pode ser "vantagem, benefício que se concede a alguém, ou vantagem devida à preferência que se recebe de alguém ou ao poder que se tem sobre alguém", segundo Houaiss. Ou seja, ocorre uma nuance da intercessão para conceder vantagem ou beneficiar alguém, ou ainda, manifestar preferência ou poder, o que não tem a conotação neutra de se fazer algo de graça ou sem a necessidade de troca. Essa acepção pode abrir um precedente para a instauração do "jeitinho".

Isto posto, uma questão se faz necessária: de que forma se dá a aproximação do "favor" com o "jeitinho"?

Borges (2006) apresenta o jeitinho como uma resultante híbrida das relações pessoais e sociais:

O jeitinho não corresponderá a uma característica de classe, será uma espécie de resultante híbrida entre as relações de favor e as relações individuais, um desdobramento dessas forças, transformando-as em outra coisa. O jeitinho acontece com a aproximação das concepções modernas e igualitárias ao sistema de valores que privilegia as relações pessoais (BORGES, 2006, p. 63-64).

O "favor" requer certo grau de conhecimento entre as pessoas envolvidas, não se pede a qualquer um. Existe algum tipo de relação de confiança (relações pessoais). $O$ "jeitinho" não requer reciprocidade. Baseia-se na ideia de que depende da oportunidade, e de que "hoje eu dei um 'jeitinho' para alguém, amanhã, eu posso precisar de alguém para me dar um 'jeitinho". Às vezes, a distinção entre "favor" e "jeitinho" se dá no nível da formalidade, com o "favor" com mais formalidade, justamente pelo fato de envolver o relacionamento entre as pessoas. Outro fator que os distingue é a ideia de que, normalmente, o "favor" não transgride normas, e que o "jeitinho" quase sempre implica em transgressões. Porém, tanto um "favor" pode infringir a lei quanto um pedido de "jeitinho" pode não transgredir normas e regras. Em razão de todas essas nuances apresentadas pelo reconhecimento do uso inadequado, por vezes, dos vocábulos, é que Barbosa (2006) sugere uma representação gráfica para as três principais categorias: "favor", "jeito" e "corrupção". 
No continuum proposto por Barbosa (2006, p. 42), o "favor" é visto de forma positiva pela sociedade. Entretanto, o "jeito" é visto tanto de uma perspectiva positiva quanto negativa.

Já Almeida (2010), nos resultados obtidos pela PESB, Pesquisa Social Brasileira, para avaliar o que a população brasileira considera "jeitinho", solicitou "que os entrevistados classificassem dezenove situações por meio de uma das seguintes denominações: Favor/ Mais favor que jeitinho/ Mais jeitinho que favor/ Jeitinho/ Mais jeitinho que corrupção/ Mais corrupção que jeitinho/ Corrupção" (ALMEIDA, 2010, p. 51). O pesquisador explica que para efeito de análise, foram consideradas como "favor" a soma das respostas "favor" e "mais favor que jeitinho".

Das dezenove situações apresentadas para classificação, quatro foram consideradas "favor", na PESB. Duas delas são do âmbito do privado: "emprestar dinheiro a um vizinho", ou "um vizinho emprestar a outro uma panela ou forma que faltou para preparar a refeição". Outras duas envolvem filas: "deixar passar na frente uma pessoa que tem poucas compras na fila de supermercado", e "guardar o lugar na fila para alguém que vai resolver um problema". As duas últimas situações envolvem o espaço público e a lógica estabelecida pela fila, de que ela é universal, geral e pública.

Outras seis situações foram consideradas "jeitinho", na PESB, apresentada em Almeida (2010, p. 54):

\footnotetext{
1 Uma pessoa que costuma dar boas gorjetas ao garçom do restaurante para quando voltar não precisar esperar na fila (59\%).

2 Uma pessoa que trabalha em um banco ajudar um conhecido que tem pressa a passar na frente da fila $(56 \%)$.

3 Uma pessoa que conhece um médico passar na frente da fila do posto de saúde $(50 \%)$

$4 \quad$ Uma mãe que conhece um funcionário da escola passar na frente da fila quando vai matricular seu filho (50\%).

5 Alguém consegue um empréstimo do governo que demora muito a sair; conseguir liberar o empréstimo mais rápido porque tem um parente no governo (45\%)

6 Pedir a um amigo que trabalha no serviço público para ajudar a tirar um documento mais rápido do que o normal (43\%).
}

O que se pode observar a partir do resultado da pesquisa, é que a utilização de um termo ou outro é controversa (aí é onde reside a importância da nuance entre os termos). Os percentuais apresentados à frente de cada situação indicam a 
parcela do universo de entrevistados que consideram tais situações como "jeitinho". Talvez, à época que a pesquisa foi realizada, entre 18 de julho e 5 de outubro de 2002, tais números fizessem mais sentido. Atualmente, há certa intolerância das pessoas em relação a terem seus direitos ignorados. Provavelmente, em uma nova pesquisa, os números se apresentassem diferentes.

Dessa forma, com os dados de que disponho para a análise, o que se pode considerar favor, recai não somente na questão das relações pessoais. De acordo com Almeida, "o favor ainda é concebido pela população como algo legítimo na esfera pública". O autor acrescenta que "a lógica estabelecida pela fila - universal, geral e pública - pode ser quebrada de maneira positiva e em função do contexto (ou porque se tem um problema ou porque se tem poucas compras). A moralidade contextual está presente inclusive na concepção do favor" (ALMEIDA, 2010, p. 55). A análise de como classificar a situação vai depender de sua configuração e das pessoas envolvidas.

Em relação à letra da canção, Antonico, o texto apresenta uma prevalência do "favor". O pedido é feito pelo Amigo a Antonico, e aquele se propõe a pagar com eterna gratidão. Em determinado sentido, se o pagamento de um favor pode ser algo simbólico, de acordo com o Ensaio sobre a dádiva, de Mauss, e que o valor das coisas não deve ser maior que o valor das relações, poderia se dizer que o favor estaria pago apenas com a gratidão do Amigo.

\subsection{Soldados brasileiros durante a campanha dos Apeninos na Segunda Guerra Mundial: o "jeitinho", a criatividade e a sobrevivência}

O texto ${ }^{74}$ que passo a analisar é o referente à participação dos soldados brasileiros da FEB (Força Expedicionária Brasileira), juntamente com as tropas aliadas na Batalha de Monte Castelo, ao norte da Itália, nos Apeninos, em combates contra as tropas alemãs, durante o período de novembro de 1944 e fevereiro de 1945.

\footnotetext{
${ }^{74}$ Durante a guerra, na campanha dos Apeninos, entrado o inverno, ocorreram sucessivas baixas de soldados com os pés gelados. O serviço de saúde começa a trabalhar e, muito americanamente, principia levantando estatísticas. O resultado inicial foi surpreendente: a maior incidência entre os americanos, que conheciam a neve, do que entre brasileiros, que a estavam vendo pela primeira vez. Analisando o fato, veio a informação espantosa: os pracinhas, ao avanço do frio, cuidaram logo de enrolar os pés em jornais, enquanto seus camaradas americanos esperavam orientação do serviço da saúde... (TORRES, 1973, p. 213).
} 
O cenário que encontramos conta com os soldados brasileiros e americanos expostos às condições climáticas bastante adversas. Neve, frio intenso, chuva. Todos padeciam, levando à ocorrência de baixas. $O$ fato de haver mais baixas entre os americanos do que entre os brasileiros intrigou o serviço de saúde, composto pelo corpo médico de ambos os países. Seria de se esperar o contrário, pois os americanos eram mais acostumados à exposição a baixas temperaturas.

Do soldado brasileiro, que é habituado ao calor, com as elevadas temperaturas tropicais, tem-se a expectativa de um número elevado de baixas, principalmente por não estarem adaptados a um inverno tão rigoroso. Porém, o que faz o soldado brasileiro? Acostumado a "se virar", não espera por ordens superiores. Forra a bota com jornal, para esquentar os pés e não padece tanto com o frio e a umidade. Esta iniciativa reduz significativamente o número de baixas.

Já o soldado americano, apesar da familiaridade com a condição climática que se apresenta, sofre com o frio, com os pés gelados, pois aguarda orientação do corpo médico. Como não há manifestação nesse sentido, o soldado americano não toma nenhuma atitude, padece e ocorrem as baixas.

Eis como se dá a configuração no nível narrativo:

Tem-se no enunciado de ser (estado), o soldado com frio, que passa para o enunciado de fazer, a partir do momento em que entra em conjunção com o objeto modal, jornal, que vai permitir que passe da privação para a liquidação da privação, altera a situação de pés gelados para os pés aquecidos, graças ao fato de estar conjunto com o objeto modal calor, que significa sobrevivência, vida, o objeto valor. Estabeleceu-se um programa narrativo de apropriação, com uma aquisição reflexiva.

O sujeito soldado tem de propor a si próprio a busca pela competência para a realização da ação. Teremos um mesmo ator sincretizando os actantes Destinador e Destinatário. O soldado brasileiro atua como Destinador e sendo ele próprio o Destinatário, teremos então uma automanipulação, que será uma manipulação por intimidação, pois o Destinatário soldado deve estar conjunto com o calor, e pode estar em conjunção se ele tiver o jornal, pois o jornal será o objeto modal que propiciará condições de o sujeito soldado alcançar o objeto modal calor. O saber e o poder fazer uso do jornal para forrar as botas e se aquecer é a competência do soldado brasileiro, que conta com a necessidade de recorrer à sua esperteza, 
astúcia, criatividade e capacidade de improviso. Como o soldado brasileiro se automanipula, ele se auto destina à ação, realizando a performance desejada, ou seja, o soldado do estado de disjunção com o objeto modal calor passa à conjunção, a partir do momento em que recorre ao jornal para forrar suas botas.

A performance proposta se concretiza. $O$ ato de forrar as botas com jornal para aquecer os pés, evitando que eles congelassem, possibilitou que o soldado sobrevivesse frente às adversidades do tempo. O Destinador julgador, ainda o soldado brasileiro, avalia a performance e pelo êxito alcançado, a sanção será positiva.

O espetáculo está descrito de forma que se podem identificar as sequências narrativas, como descrito por Fiorin (2009):

\footnotetext{
Os textos são narrativas complexas, em que uma série de enunciados de fazer e de ser (de estado) estão organizados hierarquicamente. Uma narrativa complexa estrutura-se numa sequência canônica, que compreende quatro fases: a manipulação, a competência, a performance e a sanção (FIORIN, 2009, p. 29).
}

Pudemos identificar no texto o estabelecimento de um contrato, uma manipulação por intimidação, para enrolar os pés no jornal e aquecê-los: faça, caso contrário, o sujeito padecerá e haverá baixas; a competência, que compreendeu estar de posse do jornal e ter a ideia de usá-lo para enrolar os pés; a performance, a ação que envolveu enrolar os pés com o jornal, e a sanção positiva, dada pela sobrevivência propiciada pelo calor que evitou os pés de congelarem e ocorrerem as baixas.

Haveria, ainda, nesse texto, o percurso dos actantes corpo médico, Destinador, e soldado, Destinatário, mas nem chegou a se estabelecer, ao que parece, por omissão do corpo médico. O mesmo se diria do percurso de automanipulação e autodestinação do soldado americano. Apenas que o percurso não se realizou, talvez por dependência do soldado americano do corpo médico e sua incapacidade de tomar atitude por conta própria. Habituado e confiante na hierarquia, o soldado, ao chegar o frio, fica com frio. Ele cumpre o "contrato" hierárquico, mas, por algum motivo, quem tinha que lhe dar a competência para se proteger do frio, não o fez. A performance é a hipotermia. A sanção é negativa - 
morte. Confiando no Destinador, o soldado americano não assume a autodestinação.

Assim, quando se tem uma sequência narrativa, como é o caso,

\begin{abstract}
Se uma sequência narrativa supõe percursos, se os percursos supõem programas com actantes destinador e destinatário, dois sujeitos, entre os quais circulam valores que, por isso, são considerados objeto-valor, a enunciação contém uma sequência narrativa, na medida que comporta a instância do enunciador (Destinador, S1) e a do enunciatário (Destinatário S2), em junção (conjunção ou disjunção) com valores ideológicos e sofrendo transformações (DISCINI, 2004, p. 99).
\end{abstract}

$\mathrm{Na}$ análise discursiva, identifica-se um texto predominantemente temático, com os temas da guerra e da luta pela sobrevivência. Em termos figurativos, há a presença dos soldados brasileiros e americanos, os corpos médicos, o inverno rigoroso, com a neve, frio, baixas temperaturas. Há, ainda, as botas e o forro das botas, o jornal. Na categoria de pessoa, tem-se eles, que são os soldados brasileiros e americanos, o espaço é o do Monte Apeninos, norte da Itália, e em relação ao tempo, novembro de 1944.

Nessa análise, operou-se uma debreagem, mecanismo em que se projetam os actantes do enunciado (projeção do ele-alhures-então), mais precisamente, uma debreagem enunciva, que gera um sentido de objetividade (FIORIN, 2008, p.138).

A particularidade que se identifica na sequência analisada é a automanipulação e autodestinação.

O sujeito do "jeitinho" é alguém que, inicialmente, esperou que a competência para a resolução de suas questões viesse de outro sujeito, ou pelo menos, que os instrumentos para a aquisição da competência fossem fornecidos por outro sujeito. Todavia, tal sujeito não se manifesta, mostrando-se um Destinador manipulador impotente ou omisso.

A solução do problema passou pelo "jeito" que o soldado brasileiro deu: assumir-se como autodestinador e buscar a própria solução, forrando as botas com jornal para aquecer os pés, evitando que eles congelassem. O "jeito" possibilitou que o soldado sobrevivesse frente às adversidades do tempo.

Nesse caso, o "jeito" surge como uma necessidade urgente, como resposta para a manutenção da vida, de uma forma criativa, com característica de esperteza 
e improvisação, mediante o abandono dos valores do Destinador original, centrados na hierarquia, em favor de outro, a própria sobrevivência.

\subsection{Na linha de produção: um caso de criatividade e jeitinho brasileiro}

Conta Mario Sergio Cortella que uma empresa multinacional enfrentou um problema em sua linha de produção ${ }^{75}$ : algumas embalagens saiam sem o tubo de pasta de dentes.

Para resolver o problema, a empresa contratou dois engenheiros que, ao final de três meses e ao custo de oito milhões de reais, apresentaram como solução um sistema que compreendia um programa de computador, acoplado à esteira de aço, uma balança supersensível e um braço hidráulico. A balança acusava quando o produto não estava dentro da embalagem, travava o sistema e o braço hidráulico removia a caixinha vazia da linha de produção.

Em termos de análise semiótica, no nível narrativo, observa-se que o Destinador empresa estabelece um contrato com o Destinatário engenheiro e o

75 (Palestra proferida pelo filósofo Mário Sérgio Cortella, gravada pela TV Paraná Educativa e publicada no site Youtube em 06/06/2008). Eis a transcrição do trecho em pauta:

"Há uma história, que é clássica, quem é da área de RH conhece bem, porque ela é verdadeira.

Uma estupenda multinacional fabrica de tudo, de sorvete a suco, seja o que for, sabonete, pasta de dente, eles tinham uma fábrica próxima a Campinas, em Valinhos. Eles tinham uma encrenca: há quinze anos, agora, a encrenca na fábrica de pasta de dentes, na esteira final de aço para embalamento, vinham as caixinhas de pasta de dentes, de vez em quando passava uma vazia, sem o tubo dentro. E era embalada.

Há quinze anos, você comprava, aí, não acontecia nada. Hoje você tem código do consumidor, hoje você tem o Ministério Público em cima, graças a Deus, você tem concorrência. Eles tinham que mexer nisso. O que eles fizeram: dois engenheiros, por três meses, gastaram oito milhões e chegaram a uma solução estupenda: conseguiram um programa de computador, acoplado à esteira de aço (uma coisa difícil), com uma balança ultrassensível. Quando passava uma caixinha vazia, acusava a diferença de peso (que é difícil numa máquina), parava o sistema, travava, um braço hidráulico vinha e ... tirava.

Essa é uma história real e conhecida, mas vale a pena trazê-la.

Um mês, dois, três de funcionamento (...) Perfeito, zero de rejeição, todo consumidor satisfeito. Foram olhar os relatórios, fazia dois meses que "tava" desligado. Chama supervisor, chama gerente, chama chefe. O que aconteceu? Ninguém sabia. Chegaram nos operários e falaram: "O que aconteceu?" "A gente desligou isso." "Como desligou? O que que foi?" "Ah, isso dava um trabalho danado. Toda hora parava, vinha um bracinho e tirava." "Ué, então como que tá funcionando?" "Ah, fizemos do nosso jeito." "O que que vocês fizeram?" "Fizemos uma vaquinha entre nós. Juntamos oitenta reais, compramos um ventilador daqueles 'desse' tamanho, pusemos aqui, e quando passa uma caixinha 'fiuu' (rsrsrsrs)." Atenção: dois engenheiros, três meses, oito milhões. O que eles "tavam" fazendo era uma saída? Claro. Qual era o problema? Não era a melhor saída. Onde estava a melhor saída? No estoque de conhecimento. A questão é que hoje em dia onde há concorrência, não há tempo a perder".

Disponível em: <http://www.youtube.com/watch?v=QsR_5YytNxA>. Acesso em: 12 jun. 2011. (transcrição nossa) 
manipula para que aja no sentido de resolver o problema. Este é o primeiro programa narrativo proposto.

A manipulação é de tentação, pois os engenheiros são desafiados a encontrar uma resposta para a falha que ocorria na esteira durante a embalagem dos produtos, e isso, a um custo bem elevado. A tentação da recompensa monetária pela obtenção da solução é significativa.

A performance a ser realizada é no sentido de alcançar a eficiência ${ }^{76}(\mathrm{Ov}=$ objeto valor) ao final da linha de produção. Para que ela se concretize, o Destinatário engenheiro desenvolve um instrumento $(\mathrm{Om}=$ objeto modal): o sistema acima referido.

Após três meses da instalação do sistema, a linha de produção funcionava perfeitamente, consumidores estavam satisfeitos e não havia qualquer registro de falha do sistema.

A sanção do Destinador julgador empresa seria positiva se não houvesse um porém: em avaliação realizada por meio de relatórios, verificou-se que a performance que culminou em rejeição zero não resultava da ação do Destinatário engenheiro, pois o sistema havia sido desligado há dois meses.

$\mathrm{Na}$ busca pela resposta do que havia ocorrido, chegaram aos operários. sistema havia sido desligado por eles devido à sua não operacionalidade: a cada caixa de tubo de pasta que passava vazia pelo sistema, este travava, parava a linha de produção, para que o braço hidráulico retirasse a caixa vazia, e só depois retomava o processo.

Em uma empresa cujo resultado depende da produtividade e eficácia nos processos, é importante "ter um plano de ação e de acompanhamento visando a gestão de performance e engajamento de diferentes equipes" ${ }^{\prime 77}$. No caso analisado, parece que não houve a chamada "gestão de performance", pois do contrário, o processo que envolvia o sistema criado pelos engenheiros teria obtido sucesso.

\footnotetext{
${ }^{76}$ Eficiência, segundo Houaiss: virtude ou característica de (alguém ou algo) ser competente, produtivo, de conseguir o melhor rendimento com o mínimo de erros e/ou dispêndios.

${ }^{77}$ Um dos objetivos a ser alcançado no curso de "Gestão de pessoas no chão de fábrica", oferecido pela Informa Group, empresa que oferece cursos e treinamentos de desenvolvimento e performance empresarial. Disponível em:

$<$ http://www.informagroup.com.br/site/hotsite_iir.asp?idevento=382\&menu=2887>. Acesso em: 22 out. 2013.
} 
Temos então, um segundo percurso, outro Destinador, parcialmente convergente com o primeiro, pois também visa à produtividade, manipulou outro Destinatário para que a performance fosse atingida. O Destinador em questão é o operário da fábrica, que desejava a performance alcançada, pois, na verdade, era ele quem respondia por todo o processo de produção. O Destinador operário se automanipulou e foi provocado a encontrar a solução para o problema. Assim, para praticar essa ação, o sujeito operário sabia fazer, podia fazer e queria fazer com que o sistema funcionasse e que a eficiência fosse alcançada. Como a performance foi por ele realizada, ocorreu também a auto sanção positiva.

Qual foi a solução adotada pelos operários? Invés do braço hidráulico, que travava a todo o momento o sistema para retirar a embalagem vazia, eles colocaram um ventilador ao final da linha e, quando a embalagem passasse vazia, portanto, mais leve, seria lançada para fora da esteira, sem pará-la.

Quando o sujeito operário entra em cena, automanipulando-se à ação, não se observam os meios convencionais utilizados para a execução de tal ação. Para a realização da performance, o objeto modal utilizado, o ventilador grande, adquirido em uma loja qualquer, ao custo de oitenta reais, não seria uma solução adequada aos olhos do Destinador do primeiro percurso, a empresa, tanto que a sanção positiva foi dada, inicialmente, ao Destinatário engenheiro, com o qual o Destinador estabeleceu um contrato. Foi somente após a realização de um segundo percurso, não conhecido por quem estabeleceu o objetivo inicial, que o resultado desejado foi alcançado. A sanção positiva deveria ter sido conferida ao sujeito do segundo percurso, o operário, quem, de fato, realizou a performance de modo a alcançar a eficiência.

O texto, no nível discursivo, apresenta o enunciador, na figura de Mário Sérgio Cortella, que relata o fato ocorrido há aproximadamente quinze anos, em uma multinacional, localizada em Valinhos à época, e que fabricava, entre outros produtos, pasta de dentes. Narra um problema dessa empresa, do seu grupo gerencial, no caso, os engenheiros, do operacional, os operários, e das falhas do sistema de embalagem de um produto na linha de produção. 
O texto é predominantemente figurativo, pois cria um efeito de realidade e the constrói um simulacro, representando o mundo, no caso, a fábrica, e sua linha de produção; tem a função descritiva ou representativa.

O conjunto de figuras remete ao tema da busca da eficiência, que no caso relatado, apresenta dois pontos de vista distintos: dos engenheiros e dos operários.

A ação atribuída ao engenheiro era a de resolver o problema da linha de produção, mas sua performance não foi satisfatória, pois causava paradas que atrasavam o processo. A ação pode ser tematizada como insucesso, uma vez que o objetivo de que a linha de produção funcionasse com eficiência resolvia um problema criando outro, logo, não teria sido alcançado. Porém, o objetivo, que seria todas as embalagens de pasta de dentes com tubo dentro, parecia alcançado. Entretanto, a performance não foi realizada por quem poderia, deveria e saberia, pelo ponto de vista do primeiro Destinador. A eficiência foi alcançada pelo sujeito operário que fez uso de outros meios que não os convencionais.

Assim, surge outro tema que permeia o relato, que é o da criatividade. Quando o Destinador empresa estabelece contrato com o Destinatário engenheiro, para que a ação seja realizada, o objeto modal composto pelo sistema computador, balança, braço hidráulico e esteira de aço mostra-se ideal para a execução da tarefa. Porém, o sistema não foi eficaz o suficiente e a solução mais eficiente, afirma o enunciador, estaria naquilo que ele denomina de "estoque de conhecimento" do sujeito operário. Tal sujeito realizou a performance de forma inesperada, com o auxílio do objeto modal "ventilador grande", por intermédio do qual alcançou a almejada eficiência, objetivo inicial proposto pelo Destinador empresa.

Entre as possibilidades de interpretação para o que o enunciador denominou de "estoque de conhecimento" do sujeito operário, estabeleço um diálogo com o que Oliveira Torres (1973) chamou de "estilo peculiarmente brasileiro que se revela no jeito" (OLIVEIRA TORRES, 1973, p. 212).

Há de se observar que o Destinador empresa não cogita propor o contrato ao operário. Não existe a expectativa de que outro sujeito, que não aquele que obteve seus conhecimentos de maneira formal, com um grau de bacharel, o engenheiro, seja capaz de resolver o problema que envolve o funcionamento da linha de produção. 
Tradicionalmente, o operário, que é quem atua no que chamamos "chão de fábrica", tem por objetivo atingir a produção estabelecida, até porque dela depende a permanência de seu próprio emprego. E é a aspiração de toda empresa que isso ocorra de forma eficiente e eficaz, e que os problemas sejam solucionados na fonte. Porém, as condições que normalmente são oferecidas aos operários não são as ideais para que tal objetivo seja atingido. Estes se deparam com situações adversas, tais como problemas organizacionais, dificuldade de comunicação nos diversos graus de hierarquia, falta de perspectiva em relação à evolução profissional, entre outros.

Dentre as possibilidades de solução por parte do operário, compondo seu 0 "estoque de conhecimento", pode-se encontrar a virtualidade do "jeito", a forma peculiarmente brasileira de resolver parte dos problemas.

Oliveira Torres (1973) identifica, ainda, o "jeito" em dois tipos: o prático e o teórico ${ }^{78}$. Segundo ele, "o jeito prático se traduz na capacidade de adaptação a situações inesperadas ou difíceis" (OLIVEIRA TORRES, 1973, p. 213). Talvez a situação dos operários da fábrica faça com que surjam respostas identificáveis com o "jeito" prático, que são criativas, improvisadas, e até soluções que podem, ou não, ser convencionais.

"O estoque de conhecimento" a que o enunciador se refere pode ser compreendido como uma somatória de experiências de diferentes indivíduos, que passaram pelas mais diversas dificuldades e tiveram que encontrar respostas diante de acontecimentos imprevistos e adversos para os problemas que surgiam no seu dia a dia.

Barbosa (2006) tece comentário sobre um exemplo citado por Oliveira Torres acerca do caso dos soldados brasileiros em campanha nos Apeninos, durante a Segunda Guerra Mundial, que se referia à omissão de superior hierárquico (caso estudado anteriormente), frente ao risco iminente de morte dos combatentes e à ação do soldado, para a preservação da vida. Esse caso "poderia ser considerado paradigmático na descrição de situações em que o "jeitinho" é definido como criatividade, improvisação e esperteza do brasileiro" (BARBOSA, 2006, p. 23). Nesse

\footnotetext{
${ }^{78} \mathrm{O}$ autor, Oliveira Torres, não mencionou o jeito teórico posteriormente, como também observou Barbosa (2006, p. 23).
} 
exemplo, alguns dos componentes do jeitinho foram acionados: criatividade, improvisação, habilidade, esperteza, além do instinto de sobrevivência.

Tem-se assim a expressão "jeitinho" usada por parte dos brasileiros para definir a capacidade de resolver situações que são configuradas como de difícil solução e que fogem do padrão. E ainda, segundo Houaiss, como uma maneira hábil, esperta, astuciosa de conseguir algo, especialmente algo que à maioria das pessoas se afigura como particularmente difícil.

Observando-se a situação apresentada pela empresa e os profissionais que foram acionados para resolvê-la, a expectativa de solução era plausível. Os profissionais indicados para a tarefa e a solução por eles apresentada eram adequados. Porém, o resultado não foi o esperado.

Coube a quem está acostumado aos problemas do dia a dia, às agruras de ter de resolver situações corriqueiras, a quem tem a experiência do "chão de fábrica", que é o operário, resolver o problema. Ele é quem armazena o "estoque de conhecimento" ao qual se referiu o enunciador e que, aliado à sua criatividade, jogo de cintura, improviso, enfim, com o seu "jeitinho", foi capaz de alcançar a eficiência na linha de produção.

A solução encontrada ao final não é o que se pode considerar a resposta definitiva e satisfatória. É possível conceber uma linha de produção funcionando com um ventilador improvisado? Há de se observar que tal atitude é tomada em prol de um bom andamento do trabalho do operário. Seria essa uma solução definitiva?

O "jeitinho", por ser uma resolução que foge do padrão, por estar fora das regras do estabelecido, suscita um julgamento à margem da convencionalidade. Há de se notar também seu caráter provisório: resolve aquele problema específico, não é generalizável e, muitas vezes, resolve por algum tempo, ao modo de um paliativo. Bastaria um tubo de pasta de dentes maior ser lançado, embalado em caixas maiores e, portanto, mais pesadas, o ventilador poderia não mais dar conta de "assoprar" as caixas vazias para fora da esteira. 


\title{
2.4 Moça deitada na grama: simpatia, charme e "jeitinho"
}

Moça deitada na grama ${ }^{79}$, de Carlos Drummond de Andrade, faz parte de uma coletânea de crônicas organizadas pelo autor, em um livro de mesmo nome, que foi editado meses após o seu falecimento, em 1987. Segundo Bosi (1994), Carlos Drummond de Andrade foi o primeiro grande poeta que se afirmou depois das estreias modernistas. O teórico acrescenta:

Definindo-Ihe lucidamente o caráter, disse Otto Maria Carpeaux da sua obra que "expressão duma alma muito pessoal, é poesia objetiva". Parece-me que "alma muito pessoal" significa, no caso, a aguda percepção de um intervalo entre as convenções e a realidade: aquele hiato entre o parecer e o ser dos homens e dos fatos que acaba virando matéria privilegiada do humor, traço constante na poesia de Drummond (BOSI, 1994, p.441).

Tais características não se limitam apenas à poesia. Octávio Mello Alvarenga escreveu na orelha do livro, Moça deitada na grama, editado pela editora Record:

\begin{abstract}
A moça - curiosos ou incréus de todo gênero - é idêntica e ao mesmo tempo diversa de todas as outras moças, pois resolveu deitar-se num jardim público, tal como os mendigos - e enfrenta, naturalmente, a crítica personificada num guarda. Chaplin, de novo? De novo, meus caros, e tão disfarçado de brasileiro, tão nosso na diversidade subsequente, que não é (apenas) cômico ou dramático no quotidiano; será crítico, sarcástico, sempre atuante. E guardará os limites da brandura, do meio riso, da lágrima contida, a que Drummond nos habituou.
\end{abstract}

A partir do pensamento manifesto por Alvarenga, nota-se a percepção e sensibilidade de Drummond em Moça deitada na grama, no retrato do cotidiano, no embate entre as convenções e a realidade. $O$ narrador observador que se embevece, se inebria com o que descreve e propicia esse deleite aos seus leitores. Narrador que inverte os papeis: contrapõe a determinação da moça e a fragilidade do guarda.

Em Moça deitada na grama ${ }^{80}$, da mesma forma que na crônica $A$ Lei do Verão, segundo Resende (2002), uma "apologia amantíssima do Rio", manifesta seu desejo de que tudo seja permitido, e tudo seja desculpado.

Cortada de ironia e condescendência com os pecados abaixo da linha do Equador, defende igualmente direitos e infrações porque "a praia, como a praça, é de todos", mesmo surfistas, animais cujo acesso é proibido,

\footnotetext{
${ }^{79}$ Anexo A

${ }^{80}$ Moça deitada na grama, doravante, Moça...
} 
ambulantes, turistas, banhistas seminuas e crianças desidratadas (RESENDE, 2002, p.81).

A autora ainda salienta o que ocorre em relação ao passar do tempo, "[...] é curioso constatar que, à medida que envelhece, o humor do poeta se torna mais forte, as crônicas cada vez mais divertidas, a linguagem cada vez mais deliciosamente coloquial" (RESENDE, 2002, p.81).

Pode-se atestar que esses elementos estão presentes em Moça... No coloquialismo, na crítica social, o humor. No direito a se deitar na grama da praça, seja moça "bem-vestida, bem apessoada", ou mindingo, "vagabundo fedorento", o quebrar regras, exigir tratamento igualitário, ao avesso do usual. $\mathrm{Na}$ informalidade, em que o guarda vira "meu santo", a moça fica "espichada", e também "numa boa oriental", em que o guarda assume não conhecer leis e pede para não ser exposto. $\mathrm{Na}$ simplicidade de sua escrita, o cronista humaniza o cotidiano, sem deixar de lado a crítica social.

A seguir, apresento um resumo parafrástico da crônica.

A moça estava deitada na grama, descontraída, despreocupada com o que ocorria à sua volta. Estava vestida de maneira elegante e não havia nenhum apelo erótico na forma como se apresentava. Um guarda se aproxima e toca-lhe o ombro, de leve. Ela abre os olhos, sorri e inicia um diálogo com o guarda, convidando-o para se deitar também. O guarda se desculpa e pede para que ela se levante. A moça se recusa e pondera que há outra pessoa deitada na grama, um homem. Por que seria ela a se levantar? O guarda diz que ele também não pode, mas, como é homem e mendigo... A moça manifesta indignação, apela aos seus direitos como cidadã. O guarda fica sem jeito, tenta se justificar, e a moça aproveita a situação para tentar convencê-lo, com um sorriso especial. Porém, o guarda se mostra inflexível, e diz que é melhor ela não se arriscar. A moça não cede e ele a ameaça com a lei. A moça, então, apela para a "lei da igualdade", que o guarda alega desconhecer ou achar "que não pegou". Como a moça se recusa a levantar e o guarda tem consciência de que não pode apelar para a violência, ele protesta, dizendo que a moça está a expô-lo. Ela diz que nada fez e que estava "numa boa", até ele chegar. O guarda, vendo que não ganharia a disputa, admite que é "difícil lidar com as mulheres". A moça propõe que ele faça de conta que não a viu, e que 
saia de fininho. O guarda, na tentativa de dar a última palavra, permite que ela fique, em nome da "tal lei da igualdade". No entanto, iria impor sua autoridade com o outro, o malandro, que, segundo ele, já havia gozado demais da "igualdade".

A crônica Moça... foi selecionada para compor o corpus desta pesquisa pela assunção de que a moça, estando deitada na grama, procura, de várias formas, conseguir que o guarda dê um "jeitinho", para ela ali permanecer. Não que ela considere que esteja transgredindo alguma norma, porém, quando ela se vê atormentada pelo agente da lei, tenta, pelo menos, convencê-lo a desistir de sua empreitada de fazê-la levantar-se da grama.

O cenário que está posto é o de uma praça, com gramado, provavelmente próxima a escritórios (a moça estava vestida elegantemente) e incrustada no meio da efervescência de uma cidade, com carros indo e vindo, pessoas com destino aos seus compromissos. Na praça, à tarde, bancos, observadores, transeuntes, mendigos, guarda.

Os fatos se desenrolam perante um narrador, cujo modo de presença, como observador, é o do assistente. Em relação a essa tipologia de observador, eis o que escreve Bertrand:

A presença do observador se instala no texto. O focalizador-espectador torna-se um ator explícito no interior do enunciado. Mas seu papel é então exclusivamente cognitivo. Não tem outra função a não ser construir o espaço figurativo (BERTRAND, 2003, p.125).

O enunciador narrador nos insere no texto. Apresenta um efeito de sentido de aproximação, pois se manifesta em primeira pessoa, e atua no espaço no qual a ação se desenrola: o "eu", "aqui". Em relação ao tempo, relata fato que presenciou, no pretérito perfeito e imperfeito. "A moça estava deitada na grama. [...] Eu vi e achei lindo".

Os interlocutores moça e guarda empregam o discurso em primeira pessoa, "eu", criando o efeito de subjetividade. Para o tempo, o uso do presente, do "agora", produz o efeito de proximidade da enunciação, assim como o espaço, "aqui", o parque e a grama. Com a associação das pessoas, do espaço e do tempo, têm-se a produção de um enunciado. Com a comunicação desse enunciado, "o enunciador realiza um fazer persuasivo, isto é, procura fazer com que o enunciatário aceite o 
que ele diz, enquanto o enunciatário realiza um fazer interpretativo" (FIORIN, 2009, p. 57).

No que se refere à tematização, os traços semânticos, tomados de forma abstrata, permitem as seguintes leituras:

- Tema do dolce far niente, que pode ser traduzido como suave indolência, ou o doce fazer nada, e que, segundo acepção de dicionário Houaiss corresponde à locução substantiva que significa "ócio prazeroso e relaxante". Esse tema pode ser associado tanto ao enunciador-narrador quanto ao sujeito moça. De certo modo, o relaxamento prevalece, pois, inclusive em momentos que a moça discute com o guarda, ela permanece na sua posição, deitada.

- Tema do exercício da autoridade e da lei, na figura do guarda e na sua ânsia de fazer valer sua autoridade. "Não pode porque é proibido".

- Tema da desigualdade social, que diferencia quem não tem obrigação de seguir a lei, por ser considerado excluído, por ser "[...] os mindingos, que a gente tem pena e deixa por aí...". Há, nesse tema, a questão políticoeconômica, abordando o direito do cidadão, "[...] tendo profissão liberal, pagando imposto de renda, predial, lixo, sindicato, etc., nada feito.", contrastando com a situação do mendigo, do excluído, de quem não se espera nada. Há ainda, como um subtema, a oposição de gênero, que considera que homens e mulheres têm fazeres diferentes, com papéis sociais definidos: "Bom, poder ninguém pode, é proibido, mas sendo homem, além disso mindingo...", "[...] achei que não ficava bem imitar os homens, [...]".

- Tema da igualdade dos sexos, que surge quando o guarda pede para a moça se levantar, mas diz que o homem pode ficar deitado na grama e a moça questiona: "homem pode, mulher não?". "Sendo homem e mindinho, tem direito a deitar no gramado, mas sendo mulher, [...], nada feito." "Achei que não ficava bem imitar os homens". "Ou todos se levantam ou eu continuo 
deitada em nome da lei da igualdade". "É muito difícil lidar com as mulheres, ..."

Quanto à figurativização, temos os traços semânticos sensoriais que se seguem:

- Relaxamento: deitada, deleite, embevecimento, descontração, fruição, tranquilidade, bem-estar inalterável, calma, descanso, arfar docemente, estátua (sem obrigação de ser imóvel), posição cômoda, estar numa boa.

- Obediência: é proibido, levante, em nome da lei, ceder a ato de força, cumprir a lei.

Outra figurativização pode ser reconhecida, que corresponde à oposição cidadão vs excluído:

- Cidadão: vestido azul, sapatos brancos, pulseira, dois anéis, elegante, composta, bem-vestida, bem-apessoada, reloginho, bolsa.

- Mindingo: homem diferente, elemento, vagabundo, fedorento, malandro.

Apesar de não ser o foco que tem atraído maior interesse para os estudiosos do discurso, o plano de expressão "cria novas relações com o conteúdo" (Barros, 2010, p.209). Essas relações são chamadas pela semiótica de relações semissimbólicas. No texto Moça..., com relação ao plano de expressão, temos logo no início, a seguinte repetição: "Moça deitada na grama. Moça deitada na grama. Deitada na grama. Na grama." Há uma sensibilização dos sentidos pelo som. O narrador diz que repete para seu deleite pessoal. Essa repetição, a perda de elementos das sentenças no plano de expressão pode ser associada ao marasmo, à tranquilidade, ao relaxamento que já identificamos no plano de conteúdo.

No nível narrativo, tem-se o Destinador guarda como representante da lei, e a moça como Destinatário. O sujeito guarda manipula o sujeito moça no sentido de fazer com que ela se levante da grama. É uma manipulação por intimidação. Durante o embate em que se envolvem os dois sujeitos, nenhum quer ceder à manipulação do outro (a moça também manipula, para conseguir ficar deitada na grama). A moça não cede, o Destinador guarda inverte de posição, passa a Destinatário da moça, é julgado e é sancionado negativamente, até que a deixe ficar. 
A moça faz um apelo final: sugere que o guarda vá andando, diz que sai em pouco tempo, para não dar a impressão que ela estava "cedendo a um ato de força". Atua com "jeitinho", usando de charme, simpatia, habilidade no trato, e usando dessa manipulação, de sedução - pois mantém a imagem de autoridade que o guarda tanto preza -, realiza sua performance e recebe a sanção positiva.

Uma das características do "jeitinho" é o seu caráter universal, embora apresentado como "brasileiro". No texto Moça..., pude identificar alguns de seus aspectos. Para estabelecer os parâmetros de comparação, utilizo as definições e as ponderações feitas por Barbosa (2005, p. 40), em trecho denominado O que é o jeitinho.

Inicialmente, a autora declara que todas as pessoas entrevistadas para sua pesquisa "conhecem, praticam ou fazem uso das expressões jeitinho brasileiro ou dar um jeitinho".

Além de ser conhecido e usado por todas as pessoas entrevistadas, o jeitinho é pensado como utilizado por todos na sociedade brasileira: do 'contínuo ao presidente' [...] Além do mais, para se dar ou conseguir um jeitinho é necessário apenas 'boa vontade', segundo a maioria dos informantes.

No caso da Moça..., ela espera conseguir o "jeitinho" usando como sinal de boa vontade, um sorriso especial, e o guarda, por sua vez, "dando um jeitinho", poderia fazer que não viu (a moça deitada na grama). A moça tenta criar uma sinergia, visando a uma cooperação.

Barbosa acrescenta:

Para todos, grosso modo, o jeitinho é sempre uma forma 'especial' de se resolver algum problema ou situação difícil ou proibida; ou uma solução criativa para alguma emergência, seja sob a forma de burla a alguma regra ou norma preestabelecida, seja sob a forma de conciliação, esperteza ou habilidade (BARBOSA, 2006, p. 41).

Pode-se dizer que Moça... é um caso de conciliação. Conciliar é, de acordo com Houaiss, "ato ou efeito de pôr (ou porem-se) de acordo litigantes, ou de harmonizar (ou harmonizarem-se) pessoas desavindas ou discordantes". A conciliação como forma de resolver conflitos, pode envolver "jeitinho". E é o que tenta a moça, com seus argumentos. Porém, o guarda recorre ao "Proibido pisar na grama", e como lei é lei, tem de ser respeitada. 
Ainda sobre o tema, encontra-se uma outra crônica, de Paulo Mendes de Campos, escritor e jornalista mineiro, intitulada Menina no Jardim. Há ali, também, uma tentativa de usufruto da relva de um jardim, por uma menininha de quatorze meses, que se comunica por balbucios, e, como a moça, sofre a pressão para respeitar a lei. Eis um trecho:

[...] Determinada, levantou-se do chão e correu para a relva, que era, vá lá, bonita, mas já bastante chamuscada pela estiagem. Não durou mais que três minutos seu deslumbramento. Da esquina, um crioulão de bigodes, representante dos Poderes da República, marchou até ela, buscando convencê-la de que estava desrespeitando uma lei nacional, um regulamento estadual, uma postura municipal, ela ia lá saber o quê (ANDRADE et al., 2002, p.14). E o que fazer, se é lei? Abramos um parênteses para essa questão. Apesar de existir uma lei municipal ${ }^{81}$ que estabeleça que pisar na grama é proibido, no município de São Paulo, e também em outros, essa é mais uma daquelas leis que existem, mas de que ninguém toma conhecimento. Seria uma daquelas leis que, como disse o guarda, "eu acho que não pegou".

O Brasil tem essa fama de ter leis que "pegam" ou "não pegam". Sobre esse assunto, Rosenn (1971, p. 530) explica que esta é uma discrepância entre a conduta e as normas legais que regulam tais condutas, e que os brasileiros se referem às leis da mesma forma como se referem à vacinação: têm as que pegam e as que não pegam. Para corroborar com o que diz, o autor relata uma passagem que envolveu o Ministro da Justiça de Getúlio Vargas, Francisco Campos, na década de trinta, na qual o ministro teve de responder às críticas de que uma nova lei era idêntica à outra escrita por ele mesmo. E a sua resposta foi que não haveria problema. Uma nova lei seria publicada, pois a outra não pegou.

A despeito da frase de Campos, considerada de peculiar cinismo e realidade por Koehler ${ }^{82}$ (2014), a autora argumenta: "Ela 'pega' quando responde à força ou os grandes interesses e 'não pega' quando deixa de atendê-los. Isto significa o mesmo que dizer que a lei pouco ou nada tem a ver com o público, no sentido democrático".

Se o que se diz "É a vontade do povo que confere legitimidade à norma, à lei;" correspondesse à verdade... Mas existe sempre um porém: "entretanto, a legalidade

\footnotetext{
${ }^{81}$ Lei no 10.328 , de 3 jun. 1987. Artigo 1ํㅡㄹ Inciso X. Disponível em: $<$ https://www.leismunicipais.com.br/a/sp/s/sao-paulo/lei-ordinaria/1987/1032/10328/lei-ordinaria-n10328-1987-dispoe-sobre-as-infracoes-administrativas-que-especifica-estabelece-as-respectivaspenalidades-e-da-outras-providencias.html>. Acesso em: 29 mar 2014.

82 Disponível em: <http://www.conteudojuridico.com.br/?artigos\&ver=2.47336\&seo=1>. Acesso em: 30 mar. 2014.
} 
formal é tão somente o preenchimento dos requisitos formais e organizacionais na sua feitura em todas as suas fases" (KOEHLER, 2014). Isto significa que, apesar ter de ser pensada de forma a atender aos anseios do povo e de ter-se a expectativa de que seus interesses sejam atendidos, esta é apenas uma das etapas, da confecção e da aceitação da lei, que normalmente é ignorada.

Avaliemos o que ocorre no país. No Brasil há um sem-número de leis, a cada dia dezenas delas são criadas. Por exemplo, a lei que tornou obrigatório o uso de kits de primeiros socorros em todo o país, o artigo 112 do Código de Trânsito Brasileiro. Seria a Lei o 9.503 de 23 set. 1997, e que foi revogada pela Lei 9.792 de 14 abr. 1999. Apenas quando da revogação ${ }^{83}$ é que foi observado pelos parlamentares que o Congresso deveria ser mais cauteloso ao aprovar medidas que resultassem em gastos para as pessoas. Só nesse momento é que foi discutido o fato de o kit ser desnecessário, ou lembrado que leigos não devem tentar socorrer pessoas feridas.

Pode-se dizer que, nesse caso, a vontade do povo, ainda que tardia, prevaleceu. A lei foi revogada. O que, infelizmente, não acontece com várias outras que não encontram respaldo popular.

Fechemos os parênteses e voltemos ao "Não pise na grama". Nos dias de hoje, se tal proibição existe, é ignorada por grande parte das pessoas, que estão em busca de ocupar espaços, fazer uso de áreas públicas, que são cada vez mais restritas. Porém, no que diz respeito à Moça..., nos anos oitenta, talvez a lei fosse 'mais respeitada'.

No seu desejo de fugir da obrigação, teve a moça que recorrer à gentileza, à simpatia. Convidou o guarda para se deitar e aproveitar. Abriu um sorriso. Utilizou de simpatia, charme e "jeitinho".

Não há aqui nenhuma conotação sexual. De acordo com Barbosa (2006), "uma série de visões estereotipadas sobre o sexo feminino e masculino" deturpam o que as pessoas pensam em relação ao sexo das pessoas para obtenção do "jeitinho". Registra a autora,

\footnotetext{
${ }^{83}$ Jornal do Senado. Ano V, no 846, Brasília, 31 mar. 1999. Disponível em: $<\mathrm{http}: / /$ www.senado.gov.br/noticias/jornal/arquivos_jornal/arquivosPdf/990331.pdf $>$. Acesso em: 30 mar. 2014.
} 
Quando da situação participam homens e mulheres, as coisas ficam mais fáceis, pois pessoas de sexo oposto, segundo os entrevistados, se entendem mais facilmente. Se a pessoa que estiver na situação de conceder o jeito for do sexo masculino, fica mais fácil se quem pede é uma mulher, pois entre os dois sexos existe sempre a possibilidade de charme, sedução, 'paquera' etc. (BARBOSA, 2006, p.47).

No caso da Moça..., o enunciador narrador alerta: "Não tinha nada de exibicionista, [...] Não era imagem erótica".

O tema do "jeitinho" associado ao charme e simpatia também é abordado em outros trabalhos.

Entre os artigos acadêmicos escritos por pesquisadores brasileiros em universidades estrangeiras, registro o artigo de Rodrigues et al. (2011), da Universidade de Brasília, em conjunto com dois colegas da Victoria University of Wellington, Nova Zelândia, que, em seu estudo sobre o "Brazilian jeitinho" procuraram identificar comportamentos vistos como exemplares. A pesquisa analisou sete temas que foram pontuados por seus entrevistados: simpatia, causar mal aos outros, malandragem, desrespeito às regras sociais, processos inovadores, relação de poder e compensação. Para o ponto de vista de abrangência da crônica, Moça..., utilizei o que foi considerado como simpatia.

O tema da simpatia foi o primeiro abordado no artigo. "Sympathy" ${ }^{44}$ foi definido pelos entrevistados como sendo um comportamento de interação social, de forma simpática, agradável e afável, que mostra interesse, afinidade e atração por outras pessoas quando se usa o "jeitinho". Os autores alertam para o fato de que o uso da simpatia como forma de interação social é uma característica dos povos latinos. Seu uso está relacionado ao fato dos interlocutores desejarem evitar conflitos e manter a harmonia nas relações interpessoais, segundo Triandis et al ${ }^{85}$. (1984, apud Rodrigues et al., 2011, p.31).

Ainda segundo os pesquisadores,

Simpatia é um componente básico do "jeitinho", que leva a um ponto importante: o seu uso não ocorre pelo uso de superioridade financeira ou social, mas através de relações afetivas em nome de uma camaradagem (RODRIGUES et al., 2011, p. 31, tradução nossa).

\footnotetext{
${ }^{84}$ Sympathy: Feelings of pity and sorrow for someone else's misfortune (Oxford). Sentimentos de compaixão e pesar pelo infortúnio de outra pessoa (tradução nossa).

${ }^{85}$ Triandis, H. C.; Marín, G.; Lisansky, J. \& Betancourt H. Simpatia as a cultural script of hispanics. Journal of Personality and Social Psychology, 1984, no 47, p. 1363-1375.
} 
Essa definição vem reforçar outro ponto fundamental ao qual Barbosa (2006) já fez referência e é considerado importante para a concessão do "jeitinho": "É preciso ser simpático, cordial, mostrar necessidade ou até humildade, mas jamais arrogância ou autoritarismo [...] é necessário antes de mais nada um bom 'papo' e saber pedir" (BARBOSA, 2006, p. 48).

Cordial e simpática não se pode negar que a moça assim se apresentou. Porém, não considero que ela tenha sido humilde. Quem sabe, ligeiramente arrogante. Cita leis, alega que não está sendo tratada com igualdade, fala que tem curso de caratê para se defender, e que não precisaria da ajuda do guarda para protegê-la. A relutância do guarda em conceder o "jeitinho" pode ter esbarrado nessa informação.

Outro artigo sobre o assunto, o trabalho da pesquisadora brasileira Fernanda Duarte, da University of Western Sydney, Australia, versa sobre o papel estratégico que o charme, a simpatia e o "jeitinho" têm na sociedade brasileira. Segundo a autora,

Charme é o poder de atrair, agradar e fascinar, que cria uma relação positiva na interação social. Na sociedade brasileira é extremamente valorizado e cultuado como atributo pessoal. Está intimamente ligado à simpatia, ou à empatia e o esforço por atingir a harmonia em relações interpessoais (DUARTE, 2011, p. 29, tradução nossa).

O uso do charme, simpatia e "jeitinho" associados como forma de superar o estresse da vida moderna, as dificuldades que se interpõem no dia a dia, e, por conseguinte, alcançar o objetivo, tem sua origem na leitura do "homem cordial" ${ }^{86}$, de Sérgio Buarque de Holanda.

De acordo com Holanda (1995), a respeito de expressão já dita, a contribuição brasileira para a civilização seria de cordialidade, e que daríamos ao mundo o "homem cordial". O autor assim o define:

A Ihaneza no trato, a hospitalidade, a generosidade, virtudes tão gabadas por estrangeiros que nos visitam, representam, com efeito, um traço definido do caráter brasileiro, na medida, ao menos, em que permanece ativa e fecunda a influência ancestral dos padrões de convívio humano, informados no meio rural e patriarcal (HOLANDA, 1995, p. 146).

${ }^{86}$ A expressão é do escritor Ribeiro Couto, em carta dirigida a Alfonso Reyes e por este inserta em sua publicação Monterey. (HOLANDA, 1995, p. 204). 
Importante salientar que Holanda se refere ao cordial como nascido do coração, e que procede, assim, "da esfera do íntimo, do familiar, do privado". Envolve a emoção.

Os elementos apontados pelos pesquisadores, como a simpatia, o charme e o "jeitinho", passíveis de serem identificados em Moça..., reforçam a percepção de que essas práticas tão disseminadas na sociedade brasileira, quando associadas, vêm a compor o que se denomina identidade nacional do povo brasileiro.

\subsection{A flexibilidade moral em A carteira, de Machado de Assis}

Em análise realizada no conto $A$ carteira ${ }^{87}$, de Machado de Assis, sob a perspectiva da semiótica discursiva francesa, busco, através do percurso gerativo do sentido, relacionar as questões acerca da honra, honestidade e "flexibilidade moral" que atormentam a personagem Honório.

Conto publicado em 1884, em A Estação, revista carioca da época do Brasil Império, $A$ carteira é a história de um homem, Honório, e seu conflito em relação ao que fazer quando acha uma carteira recheada de dinheiro na rua. Ele é um advogado, sem muita projeção, endividado, preocupado em atender aos caprichos da mulher, D. Amélia, que vive entediada. Há um amigo, Gustavo, também advogado, frequentador assíduo de sua casa. Quis o destino que ele fosse dono da carteira. O que fazer? Este é o mote do conto.

O contexto histórico do conto é o da cidade do Rio de Janeiro, ao final da segunda metade do século XIX.

O Rio de Janeiro, já naquela época, era uma cidade em que as mansões e palacetes dividiam espaço com regiões de moradias miseráveis. Havia os endereços nos quais podiam se encontrar as últimas novidades de Paris; uma aristocracia que frequentava salões e espetáculos de ópera, nos quais a língua corrente era a francesa. Em contraponto a essa situação, milhares de pessoas viviam precariamente, expostas a doenças, sem trabalho, recorrendo ao meretrício e à malandragem como forma de sobrevivência.

Abro parênteses para o tema da malandragem. Em A Dialética da malandragem, de Antônio Cândido (1970), um ensaio sobre As memórias de um

${ }^{87}$ ANEXO B, ao final do texto. 
sargento de milícias, de Manuel Antônio de Almeida (1852), contemporâneo de Machado, mostra Leonardo Pataca Filho como o primeiro malandro da literatura brasileira. Eis o que Cândido escreve sobre tal personagem:

\begin{abstract}
O malandro, como o pícaro, é espécie de um gênero mais amplo de aventureiro astucioso, comum a todos os folclores. Já notamos, com efeito, que Leonardo pratica a astúcia pela astúcia (mesmo quando ela tem por finalidade safá-lo de uma enrascada), manifestando um amor pelo jogo-emsi que o afasta do pragmatismo dos pícaros, cuja malandragem visa quase sempre ao proveito ou a um problema concreto, lesando frequentemente terceiros na sua solução (CÂNDIDO, 1970, p.70).
\end{abstract}

Na região central da cidade do Rio de Janeiro, zona portuária, cenário do conto, não seria de se estranhar a ocorrência de pequenos golpes e a presença de batedores de carteira. De certa forma, a malandragem grassava. Seria possível reconhecer tal tema também na obra Machadiana, de acordo com Leal (2002):

A dialética da malandragem de Machado é o resultado literário das condições sociais, que ele percebe e aponta, com extrema acuidade, através de uma ótica galhofeira livre, não dogmatizada pela política ou pela ideologia. Machado demonstrou sempre uma posição de independência intelectual que não deve ser confundida com alienação (LEAL, 2002, p.36).

Para exemplificar, Leal faz referência a uma publicação de Machado, sob o pseudônimo de Malvólio, de 1886, para a Gazeta de Hollanda, sobre um boticário que inventa um cozimento contra os perigos de uma peste, e vê nisso uma chance de enriquecer. A fórmula era inócua e o boticário assume sua falta de caráter. Completa o autor, "aí se revelam as convicções de Machado, que também descrê da bondade natural do homem. O bom selvagem não é um personagem machadiano" (LEAL, 2002, p. 36).

Portanto, e fecho os parênteses, ao conviver com essa realidade do Segundo Reinado, Machado produziu uma crítica social com uma profunda ironia, de um humor velado e amargo em relação àquilo que retrata, contrapondo, por vezes, certa veia cômica e satírica.

E o que se pode dizer do narrador de Machado?

Schwarz (2004), em A viravolta machadiana, assim escreve sobre o narrador de Machado durante a fase na qual está compreendido o conto $A$ carteira: desacatando os pressupostos da ficção realista, ou seja, os andaimes 
oitocentistas da normalidade burguesa. A novidade está no narrador, humorística e agressivamente arbitrário, funcionando como um princípio formal, que sujeita as personagens, a convenção literária e o próprio leitor, sem falar na autoridade da função narrativa, a desplantes periódicos. As intrusões vão da impertinência ligeira à agressão desabrida (SCHWARZ, 2004, p.16).

O autor acrescenta ainda que, durante o período de 1880 a 1908, Machado escreveu de quatro a cinco livros e algumas dezenas de contos de grande categoria, em que afasta a "mistura romântica de colorido local, romanesco e patriotismo, ou seja, da fórmula fácil e infalível em que o público leitor da jovem nação se comprazia" (SCHWARZ, 2004, p. 16).

Nesse período, Machado se aprimora, torna-se implacável em sua crítica social e assume a tarefa de apreender a maneira de ser e de agir do brasileiro.

Com isso, tem-se o panorama traçado, que possibilita o embasamento da discussão sobre a flexibilidade moral e o "jeitinho brasileiro" em A carteira.

O texto apresenta um narrador que descreve a ação em uma debreagem enunciva, Honório, o espaço, a Rua da Assembléia, imediações do Largo da Carioca, no centro da cidade do Rio de Janeiro e o tempo, por volta de 1884.

O dilema é descrito pelo narrador de forma que, mesmo após a decisão do ator Honório de devolver a carteira, o enunciatário não deixa o enunciador ${ }^{88}$ escapar ileso. O conhecimento da traição que envolve a esposa, D. Amélia, e o amigo, Gustavo, pode provocar o desejo no leitor por um desfecho com uma inversão de valores: simpatiza com a ideia de Honório se apossar do dinheiro contido na carteira e pensa que ele não deveria ter agido com honradez e honestidade.

O que quero dizer com "o enunciatário não deixa o enunciador escapar ileso" é no sentido de que o enunciatário, concretizado num leitor real, ao descobrir a traição da mulher de Honório, Amélia, com o amigo, Gustavo, não consegue deixar de julgar a decisão do enunciador de fazer Honório devolver a carteira. Pode desejar que Honório não aja de acordo com a ética e a moral, com honestidade; pode ansiar que ele ao menos fique com o dinheiro para saldar suas dívidas e diminuir sua angústia. Tal possibilidade pode ser justificada, pois, percebe-se que Gustavo não se abala com o fato de ter perdido a carteira; para ele o dinheiro não parece fazer

${ }^{88} \mathrm{O}$ enunciador e o enunciatário são o autor e o leitor, mas não o autor e o leitor reais, em carne e osso, mas sim o autor e o leitor implícitos, ou seja, uma imagem do autor e do leitor construída pelo texto (FIORIN, 2008, p. 138). 
diferença e sua preocupação é outra e muito maior: de o amigo descobrir sua traição.

Pode-se identificar, dessa forma, o que Cortina (2000) menciona em relação à Machado de Assis e sua forma de envolver o leitor em seus textos:

\begin{abstract}
Pode-se falar, assim, de duas instâncias que se concretizam no processo de leitura. Num primeiro nível, todo texto apresenta em sua organização uma "imagem de leitor", seu narratário, capaz de compreender a mensagem veiculada da exata maneira como seu narrador pretendeu expressá-la. Esse "leitor ideal" é um actante porque está inscrito no processo formador do discurso e corresponde ao sujeito imaginário para quem o narrador dirige sua voz. Ele é parte material do discurso enunciado e pode assumir um contorno mais ou menos definido conforme seja a intenção do narrador.

No caso dos romances de Machado de Assis, por exemplo, seu narratário se concretiza na figura do leitor que o narrador muitas vezes invoca quando pretende discutir explicitamente aquilo que está sendo contado (CORTINA, 2000, p. 22).
\end{abstract}

No caso de $A$ carteira, o enunciador-narrador Machado não invoca o leitor para discutir, como o faz em Memórias póstumas de Brás Cubas. Esse papel é reservado à consciência, que é com quem o personagem Honório trava um embate no sentido de decidir se fica ou não com o dinheiro da carteira. Contudo, o desfecho dado à história pode causar raiva em parte dos leitores, que ao tomar conhecimento da traição, por causa da posição altiva de Honório, baseada na honra, frustra-se por não "dar o troco" aos amantes.

Retomando o percurso gerativo do sentido, ainda no nível discursivo, identifico no conto a figurativização de uma vida repleta de luxos e superficialidades que levam à tematização da dívida, do fingimento, do segredo, da ironia, da desconfiança, da amargura, enfim, de uma vida guiada pelas aparências.

Assim se dão os acontecimentos: Honório acha a carteira. Abaixa-se, apanhaa e a guarda. Ninguém vê, exceto um homem que julga que a carteira seja de Honório, "Olhe, se não dá por ela; perdia-a de vez" (Assis).

A carteira passa a ser o objeto valor $O v^{89}$ e se torna o alvo da questão moral: ficar ou não com o que houver nela.

Ora, Honório está endividado. Tem dívida de "quatrocentos e tantos mil-réis", a ser paga no dia seguinte, empréstimos para servir a parentes, gastos de família

${ }^{89}$ A carteira será tomada como objeto valor Ov simbólico, pois o que está em questão é o dinheiro que parecia haver nela, "a carteira trazia o bojo recheado". 
excessivos, agrados à mulher, que vivia aborrecida, enfim, precisava "avaliar a oportunidade" de saldar a dívida com o que houvesse na carteira.

A carteira apresenta como conteúdo mínimo fundamental a questão moral da honradez em contraste com a flexibilidade moral. Honradez, que segundo Houaiss é a observância dos princípios por que se pautam os deveres da moral e da justiça; honestidade, probidade, dignidade. Pode-se notar sua presença em Honório, no embate com a sua consciência, em seu desejo de se manter fiel a seus princípios. "Flexibilidade moral", pode ser, em uma das suas possíveis interpretações, uma maneira sutil de imoralidade, de se obter algo por uso da falta de caráter, que pode possibilitar às pessoas atingirem seus objetivos pessoais. Honório a traz à tona quando tem dúvidas e se sente tentado a ficar com a carteira e seu conteúdo, para pagar parte de sua dívida. O dilema está posto.

No nível narrativo, temos dois percursos em embate. Num, o Destinador e o Destinatário são o mesmo sujeito, Honório. Nesse arranjo, Honório é manipulado por tentação (Livro-me de parte das minhas dívidas?) e deseja tomar para si a carteira e seu conteúdo. No segundo, o Destinador é representado pela moralidade, pelo quadro de valores da sociedade à qual Honório pertence e que ele assume como seu. Nessa configuração, Honório é manipulado por intimidação (quem ele é? Honesto ou não?) e deve devolver a carteira.

O Destinatário enfrenta um conflito moral: ou ele estabelece um contrato consigo para a execução de uma performance que envolve uma manipulação por tentação e entra em conjunção com o Ov carteira, ou estabelece o contrato com uma manipulação por intimidação, fica em disjunção com o Ov e procura pelo dono para restituí-la. São, então, dois percursos narrativos distintos, com duas alternativas conflitantes, que se apresentam a Honório.

O primeiro percurso narrativo é aquele em que o Destinatário decidiria ficar com a carteira, abandonando a questão moral suscitada pela situação. O sujeito Honório, cheio de dívidas, teria a oportunidade de saldá-las, utilizando o dinheiro que se encontra na carteira que ele achou. Essa seria a solução para uma parte de seus problemas. Nesse percurso, o contrato é proposto com manipulação por tentação. 
O segundo percurso é aquele em que o Destinatário não se apossaria da carteira, situação na qual ele a devolveria ao dono, pois sua consciência teria se sobreposto, no embate moral. Ocorreria uma manipulação por tentação: que sujeito é você, que, ao ver-se em dificuldade, sucumbe à tentação e pensa em saldar suas dívidas com dinheiro alheio?

O contrato que vence é aquele no qual o Destinador valoriza a moral, ou seja, o segundo percurso, em que o Destinatário fica em disjunção com a carteira.

Apesar de tentar se iludir com a ideia de ficar com a carteira, "[...] um lance da fortuna, a sua boa sorte, um anjo [...]", o seu crer não o deixa ir mais longe: "Honório teve pena de não crer nos anjos [...]. Se houver um nome, uma indicação qualquer, não posso utilizar-me do dinheiro". Nesse excerto, pode-se identificar a configuração do conflito moral. Na avaliação de Honório, ele não pode e não deve ficar com a carteira, apesar de querer ficar com ela, pois fica tentado ao pensar que representaria a solução de alguns de seus problemas. O fato de pensar em fazer uso de algo que não Ihe pertencia, buscando um benefício pessoal, possibilita o reconhecimento do espectro da "flexibilidade moral".

O tema da "flexibilidade moral" está presente na obra de Maquiavel, 0 príncipe, em que ele abordada as qualidades que queria ensinar aos governantes de sua época. Maquiavel "endossa o postulado convencional de que virtù é o nome que designa uma série de qualidades que permite ao príncipe aliar-se à Fortuna e conquistar honra, glória e fama" (SKINNER, 2012, p. 57).

Skinner (2012) comenta que Maquiavel dissocia o sentido de virtù das virtudes cardeais (prudência, justiça, fortaleza e temperança). E acrescenta que:

Em lugar disso, Maquiavel sustenta que a característica definidora de um príncipe realmente virtuoso é a disposição de fazer o que dita a necessidade - seja a ação má ou virtuosa - a fim de alcançar seus fins mais altos. Assim, a virtù passa a designar exatamente a qualidade da flexibilidade moral indispensável a um príncipe: "Ele deve estar preparado para alterar sua conduta quando os ventos da fortuna e a variação das circunstâncias o forçarem a isso" (SKINNER, 2012, p. 57).

Ainda segundo Skinner, Maquiavel expõe o dilema principal que enfrentam os príncipes:

Um governante que deseja manter o poder deve estar preparado para agir imoralmente quando for necessário"; mas por outro lado, deve cuidar para 
não adquirir a fama de ser um homem cruel, pois isso, em vez de assegurar, destruirá seu poder. O problema é como evitar parecer cruel quando não se pode deixar de agir cruelmente (SKINNER, 2012, p. 59).

$\mathrm{E}$ acrescenta adiante, em relação às dificuldades que o príncipe tem de transpor:

Basta ao príncipe lembrar que, embora não seja necessário ter todas as qualidades usualmente consideradas boas, é indispensável parecer tê-las. E desejável ser considerado generoso; é sensato parecer clemente e não cruel; é essencial geralmente parecer meritório. Assim, a solução é se tornar um grande simulador e dissimulador, aprendendo a habilidade de "confundir astuciosamente os homens" e fazê-los crer em seus fingimentos (SKINNER, 2012, p.61).

A discussão em torno da "flexibilidade moral" apresentada por Maquiavel se dá acerca da disposição do estadista (no caso, o príncipe), de fazer uso de sua capacidade de controlar a ocasião, utilizando-se de suas capacidades pessoais e do curso dos acontecimentos, do destino, conquistando, assim, honra e glória para si e segurança para seu governo.

Ainda, de acordo com Maquiavel, o príncipe precisaria fazer uso não só de suas qualidades humanas, como a coragem e a justiça, como também necessitaria lançar mão de atitudes de força e esperteza, associados ao leão e à raposa. Quando o mandatário não contasse com as qualidades e nem com os bons ventos do destino, para que o povo nele acreditasse para poder governar, fingiria e teria atitudes distintas daquelas que eram reconhecidas pela moral clássica. Os moralistas romanos, além das quatro virtudes cardeais, acrescentariam a honestidade como a virtude central, a magnanimidade do príncipe, e a liberalidade, todos descritos em De Officiis, de Cícero. No Livro II dessa obra, Cícero observa que muitos homens acreditam "que uma coisa pode ser moralmente certa sem ser conveniente, e ser conveniente sem ser moralmente certa" (Cícero, apud SKINNER, 2012, p. 53). E acrescenta: "Mas isso é só ilusão, pois somente por métodos morais podemos esperar alcançar o objeto de nossos desejos. Qualquer aparência ao contrário será totalmente enganadora, pois a conveniência nunca pode estar em conflito com a retidão moral" (Idem).

Como mostram os trechos destacados, a "flexibilidade moral" não é recente. $A$ questão da conveniência abordada por Cícero compreende, de certa forma, o que se tem em mente quando se lança mão da flexibilidade moral. Hoje, as pessoas têm um 
entendimento mais amplo de seu significado; ela não mais constitui uma prerrogativa só do mandatário de uma nação/país, está disseminada entre os cidadãos. Uma das formas de entendê-la seria a possibilidade de alcançar, por exemplo, uma estabilidade financeira à custa de um ato considerado imoral. Seria a disposição de fazer o que for necessário para alcançar o que se almeja, tanto no campo profissional, político, econômico ou no âmbito social. Tal compreenderia omissões voluntárias, algumas inverdades e mentiras em diferentes graus. Portanto, algum expediente em desacordo com a moral ao qual se recorre para resolver problemas.

Haveria outras formas de entendimento da "flexibilidade moral"? Provavelmente. Entretanto, vale ressaltar que as fontes bibliográficas consultadas acerca da temática ficaram restritas à área da filosofia.

Retomando o texto, quando Honório encontra a carteira, surge uma série de questões de ordem ética e moral. Ele precisa do dinheiro, mas, e se nela houver algum sinal de seu proprietário? Ou mesmo, se não houver identificação, não deveria a carteira ser entregue à polícia ou algum órgão competente, que poderia descobrir o dono?

Segundo Harkot-de-La-Taille e La Taille (2004), quando se tem a preocupação com a moral, ela "diz respeito à dimensão dos deveres e corresponde às respostas dadas à 'como devo agir?'”. Já a ética, ainda de acordo com os autores, "diz respeito à busca do sentido da vida e corresponde à pergunta 'que vida eu quero viver?'" (HARKOT-DE-LA-TAILLE e LA TAILLE, 2004, p. 70).

O dilema que aflige Honório é da ordem da moral, pois os questionamentos que ele faz a si são referentes a como agir, qual o seu dever como cidadão.

Reflete, igualmente, preocupação com seu próprio Eu, que é apreendido por meio de representações-de-si, que seria como o sujeito, no caso, Honório, concebe a si próprio. Ainda em Harkot-de-La-Taille e La Taille (2004),

\footnotetext{
A afetividade voltada para si próprio (narcisismo) faz com que tais representações sejam sempre valor. Logo, pensar em si é sempre julgar-se. E julgar-se implica pensar-se em uma escala de valores (bom/mal, bonito/feio, forte/fraco, desejável/indesejável, etc.). Consequentemente, as representações-de-si devem ser pensadas em dois níveis: o que julga ser e o que se almeja ser, Ao que se almeja ser pode-se dar o nome de 'boa imagem' (ver Harkot-de-La-Taille, 1999). Portanto, uma pessoa pode ver a si própria numa relação de conjunção com a ou as 'boa(s) imagem(s)' que tem de si, ou de disjunção com elas (HARKOT-DE-LA-TAILLE e LA TAILLE, 2004, p. 72).
} 
Em que pese a dúvida, a consciência, a questão da moral, da honra; as representações-de-si; a "boa imagem", "o conjunto de projeções de si que o sujeito faz, quando confiante e relaxado" (HARKOT-DE-LA-TAILLE, 1999, p.28) há ainda, por vezes, a preocupação com o "outro", que desperta o medo de uma opinião desfavorável. Esse "outro" seria o sujeito por quem se nutre estima ou com quem se julga "competir conceitualmente", como afirma Harkot-de-La-Taille (1999).

O receio do olhar alheio faz-se presente no conto, no momento em que Honório, após achar a carteira, entra em um Café e quase se esconde, preocupado, olhando para fora. Há, também, o fato de Honório ocultar que passa por dificuldades financeiras, e quando o amigo lhe pergunta “Tu agora vais bem, não?", Honório responde "Agora vou", mentindo para o amigo, por quem nutre estima e com quem tenta competir profissionalmente, pois ambos são advogados.

É possível constatar que, de fato, no nosso dia a dia, há uma preocupação com o "outro", com o que meu amigo pensaria de mim se me visse agindo no descumprimento de uma lei, por exemplo. Em relatório de 2013, apresentado por um grupo de pesquisadores da Escola de Direito de São Paulo da Fundação Getúlio Vargas, sobre o índice de percepção do cumprimento da lei (IPCL), os entrevistados responderam a perguntas que fariam parte da produção do indicador de controle social. Tal índice apresenta o percentual de desaprovação de pessoas próximas a eles, caso tivessem realizado algumas das situações hipotéticas apresentadas no questionário como: levar itens baratos de uma loja sem pagar; dirigir depois de ingerir bebida alcoólica; dar dinheiro a um policial ou outro funcionário público para evitar ser multado; entre outras. Os dados apresentados mostram um alto grau de desaprovação das pessoas. No relatório, $80 \%$ dos entrevistados consideram que é difícil desobedecer à lei e continuar sendo respeitado pelas pessoas (Relatório IPCL Brasil, 4ำ TRI/2012 - 1 TRI/2013, p. 12). Segundo informação dada em entrevista por uma das pesquisadoras, a desaprovação seria um item inibidor da ação da maioria das pessoas.

No conto, Honório avalia essa possibilidade de se aproveitar da situação: "Chegavam mesmo a dizer-lhe que, se fosse ele que a tivesse perdido, ninguém iria entregar-Iha; insinuação que Ihe deu ânimo". O enunciador narrador manipula o enunciatário leitor apresentando o sujeito Honório em um ambiente hostil e o 
convida a fazer escolhas: agir de acordo com a honradez ou com a falta dela. Em um contexto em que a honradez mostra pouco valor (jogo de aparências, mentiras, traição), a manipulação atua no sentido de que o leitor torça para que Honório não entregue a carteira. Se o enunciador tivesse apresentado o problema de um outro modo, por exemplo, com um amigo fiel, leal, o leitor provavelmente não torceria pela não devolução da carteira.

Honório, porém, age ao contrário, não por ter identificado o dono da carteira, e sim, de acordo com a sua consciência, optando pela virtude. Resistiu à tentação. Lutou contra o medo e a necessidade. Não obteve sua recompensa: a gratidão e o reconhecimento do amigo. Ao contrário, teve ainda que sentir o olhar desconfiado do amigo, cujo motivo ele nem imagina" 90 , que para ele foi "como um golpe de estilete".

O tema da "flexibilidade moral" está presente em A carteira, com o dilema que Honório enfrenta, em suas conversas com a consciência como se fosse um pano de fundo. No entanto, a decisão final de Honório é de não ceder. É de agir de acordo com seus princípios morais e não tirar proveito do acaso que se configurou para resolver seu problema financeiro.

Então, por que associar A carteira com o "jeitinho brasileiro"?

O conto de Machado nos remete à situação que estabelece o seguinte dilema: até que ponto é justo devolver a carteira e seu conteúdo a quem não precisa, mas principalmente, devolvê-la a quem se sabe, traiu o amigo com esposa dele. $O$ ato de ficar com a carteira seria uma forma de restabelecer a justiça e o "jeitinho" seria o mecanismo alternativo capaz de diminuir a sensação de injustiça.

O "jeitinho", em suas várias leituras, também passa pelo entendimento que a mídia lhe dá, e que é corrente em nossa sociedade, sobre como as pessoas agem quando se defrontam com objetos ou dinheiro perdidos. Quando as pessoas procuram pelos donos, são louvados, considerados heróis. Se não tomam essa iniciativa, recorre-se ao "jeitinho" para justificar tal atitude: é o brasileiro que quer se beneficiar da situação, que "quer levar vantagem em tudo, certo?". Passa a existir, então, uma associação entre a malandragem e o "jeitinho".

${ }^{90}$ Gustavo temia que Honório tivesse achado e lido o bilhetinho de amor que estava na carteira e era endereçado à $\mathrm{D}$. Amélia, mulher de Honório. 
Lívia Barbosa, em seu livro sobre o "jeitinho brasileiro", cita que se utilizou de pesquisa empírica com cerca de duzentas pessoas de diferentes idades e segmentos, em quatro cidades, no período de 1984 a 1986. Em seus apontamentos relata que, para os entrevistados, "em relação à definição do que é o jeitinho não ocorreram grandes variações" (BARBOSA, 2006, p. 40).

E continua:

Para todos, grosso modo, o jeitinho é sempre uma forma "especial" de se resolver algum problema ou situação difícil ou proibida; ou uma solução criativa para alguma emergência, seja sob a forma de burla a alguma regra ou norma preestabelecida, seja sob a forma de conciliação, esperteza ou habilidade (BARBOSA, 2006, p.41).

Esta maneira simplista de enxergar o "jeitinho" encerra em si certa banalização, traz mais confusão ao escopo da formulação e não ajuda no entendimento do "jeitinho" como "elemento de identidade" do brasileiro. Ao contrário, a definição sendo predominantemente negativa, possibilita leituras nada lisonjeiras.

Em $A$ carteira ou nas situações similares estampadas nas diversas mídias, o fato é que, ao ficar com o que não nos pertence, tendo conhecimento do dono, não se está burlando uma regra ou norma preestabelecida, está se praticando um delito $^{91}$. O que vem à baila é o sentido da virtude, da "nossa capacidade de agir bem e devidamente", segundo Comte-Sponville (1995).

Assim, podemos refletir que se a designação de diversas situações fosse cunhada com outras expressões, talvez houvesse a dispersão dessa aura negativa que paira sobre o "jeitinho brasileiro". Ou seja, ao pagar propina a um agente público para se livrar de uma multa, a pessoa não usaria a expressão "dei um jeitinho" para designar o seu ato. Diria apenas: "subornei um agente público".

Minha provocação é no sentido de que se diminua a elasticidade semântica da lexia "jeitinho" ...

91 Delito: qualquer ato que constitua uma infração às leis estabelecidas; ato considerado punível pelas leis que regem uma sociedade; crime, infração; transgressão da moral ou de preceito preestabelecido; falta, infração, segundo Houaiss. 


\title{
2.6 Abrigo de vagabundos: "jeitinho", arranjo, prevaricação ou solidariedade e sobrevivência?
}

A composição de Adoniran Barbosa, Abrigo de Vagabundos $^{92}$, de 1959, compõe o corpus da minha pesquisa, com a análise do "jeitinho" em uma das suas vertentes. Para situar onde a canção se insere na obra do autor, apresento um pequeno histórico, a partir de um dos seus grandes sucessos.

Saudosa Maloca, de 1951, introduz o tema da moradia (e da falta dela) e dos infortúnios de uma parte da população migrante de uma cidade grande como São Paulo. Esse é o universo do autor. Ali, ele retrata a perversidade da especulação imobiliária, o desenvolvimento desenfreado ao qual a metrópole já estava sujeita e como nela viviam seus moradores mais humildes.

Marca peculiar do autor, nascido João Rubinato, em 1910, na cidade de Valinhos, era a forma de compor ${ }^{93}$, sem se preocupar com a correção da língua. Isso Ihe rendia inúmeras críticas, que ele rebatia dizendo fazer canções com erros de português porque era assim que o povo falava e que o samba ficava mais bonito de cantar.

Sobre essa maneira de falar, Contier et al. (2003, p.131), escrevem:

\begin{abstract}
A sua linguagem não é do negro, nem do branco, muito menos do italiano. É a típica linguagem do "Bexiga", reduto de seus imigrantes que não são mais italianos porque se "nacionalizaram" por meio da miscigenação cultural. A linguagem é uma mistura da fala do italiano, do mulato e do branco que moram nos cortiços e nas "malocas". É, sobretudo, uma linguagem que se pretende crítica porque o progresso é uma realidade para as classes mais favorecidas economicamente. Ao povo simples e excluído dos benefícios do desenvolvimento resta o "progressio" que significa, entre outras coisas, habitar "malocas" junto aos lixões da cidade que não pára de demolir para construir. E no ato de demolir, destrói não apenas os casarões, mas também a memória cultural da cidade de São Paulo.
\end{abstract}

Assim, o dia a dia de Adoniran, junto ao povo mais simples, como menciona Contier et al., levava-o também a presenciar a ocupação de casarões abandonados, a demolição dos cortiços e malocas.

92 Disponível em: <http://letras.mus.br/adoniran-barbosa/43962/>. Acesso em: 24 jan. 2013.

${ }^{93}$ Disponível em: <http://almanaque.folha.uol.com.br/adoniram.htm>. Acesso em: 4 abr. 2014. 
Segundo André Spera ${ }^{94}$ (2010), em reportagem sobre o centenário do compositor, Adoniran contava que o Mato Grosso, o Joca e o Corintiano, que se ocupavam com pequenos biscates, eram companheiros com os quais se reunia e ficava a bater papo. A prosa acontecia em um prédio abandonado, o antigo Cine Áurea, onde os amigos tinham morada. Um dia, ao chegar lá, o prédio estava no chão: havia sido demolido. Não teve mais contato com os amigos. Foi então que resolveu compor a Saudosa Maloca.

Como Saudosa Maloca, as composições de Adoniran eram alimentadas pelos dramas dos tipos que habitavam seu universo: os excluídos sociais, moradores dos bairros industriais, dos subúrbios e dos cortiços e malocas. Fatos retratados nos jornais serviam de mote para suas composições, como foi o caso do acidente de trânsito que vitimou uma mulher na Rua da Consolação e que inspirou Iracema.

Em Abrigo de Vagabundos, 1959, o enunciador narrador faz referência a Mato Grosso e o Joca, de Saudosa Maloca. Contudo, há uma mudança na vida do enunciador narrador: de sem teto passa a ser proprietário. Já não se encontra mais em companhia de Mato Grosso e Joca, dos quais perdeu contato e não tem notícias. Nesse período, o narrador tornou-se um trabalhador, em uma fábrica de cerâmica. Arranjou dinheiro, que ele deve ter juntado, e uma vez que tinha posse, comprou um lote, de dez de frente e dez de fundos, e nele construiu a sua "maloca".

Eis a letra da canção:

\author{
Eu arranjei o meu dinheiro \\ Trabalhando o ano inteiro \\ Numa cerâmica \\ Fabricando potes \\ e lá no alto da Moóca \\ Eu comprei um lindo lote dez de frente e dez de fundos \\ Construí minha maloca \\ Me disseram que sem planta \\ Não se pode construir \\ Mas quem trabalha tudo pode conseguir \\ João Saracura que é fiscal da Prefeitura \\ Foi um grande amigo, arranjou tudo pra mim \\ Por onde andará Joca e Matogrosso \\ Aqueles dois amigos \\ Que não quis me acompanhar \\ Andarão jogados na avenida São João
}

${ }^{94}$ Disponível em: <http://vejasp.abril.com.br/materia/adoniran-barbosa-um-centenario-ele-continuaatual>. Acesso em: 4 abr. 2014. 
Ou vendo o sol quadrado na detenção

Minha maloca, a mais linda que eu já vi Hoje está legalizada ninguém pode demolir

Minha maloca a mais linda deste mundo

Ofereço aos vagabundos

Que não têm onde dormir

$\mathrm{Na}$ canção, o sujeito trabalhou, arranjou o dinheiro, comprou um lote e nele construiu sua maloca. É de conhecimento público que, para se construir em um lote, precisam-se obter licenças ${ }^{95}$, recolher taxas junto à prefeitura da cidade. Só após esses trâmites e a autorização concedida é que se pode efetivamente levantar a construção. O sujeito em questão vai atrás de um fiscal da prefeitura para "arranjar as coisas" em relação à construção. E consegue. A maloca está erguida, legalizada, ninguém pode demolir. É linda e está à disposição dos amigos e dos vagabundos que não tiverem onde dormir.

Passemos para a análise do nível narrativo. Tem-se o sujeito dono da maloca, nomeá-lo-ei sujeito-trabalhador ${ }^{96}$ (ST), que construiu sem planta e procura a legalização através de um amigo. Para ele, "quem trabalha tudo pode conseguir". $\mathrm{O}$ que é uma ilusão.

Sob a perspectiva do ST o objeto maloca é o seu desejo, ele quer tê-la. Um teto sobre sua cabeça é indispensável para todo ser humano, principalmente para o trabalhador; ele deve tê-lo. O sujeito considera que é possível tê-lo, pois arranjou dinheiro trabalhando o ano inteiro, e sabe tê-lo, pois o abrigo existe, está lá (é verdadeiro), erguido em seu lote de dez (metros) de frente e dez de fundos.

A constituição do sujeito do fazer, o ST, será analisada do ponto de vista de sua vontade, uma vez que ele quer fazer sua moradia; de sua determinação, pois julga que deve fazer para ter um teto para se abrigar; de sua competência calcada em seu poder fazer, pois tem os recursos financeiros necessários para a empreitada e em seu saber fazer (saber construir ou pagar quem constrói).

Porém, existe um problema importante e determinante, que participa da competência social: não se constrói uma edificação sem planta. O que fazer?

${ }^{95}$ SÃO PAULO: Lei № 8.382 , de 13 de abril de 1976.

Institui o Cadastro de Edificações do Município, e dá outras providências. (Regulamentada)

(Alterada). Existem leis mais atuais.

${ }^{96}$ Sujeito-trabalhador, doravante ST. 
O ST não acha justo que ele queira fazer, deva fazer, possa fazer e saiba fazer (no nível concreto) sua moradia, para si e para os vagabundos, mas não possa fazer e não saiba fazer (no nível abstrato), face à lei, que não the permite.

Na verdade, o seu poder fazer - a sua liberdade - fica tolhido pelo não poder fazer da lei. Ou seja, no âmbito concreto ele é um sujeito realizado - tem a competência e a performance para construir sua maloca. Porém, no plano social ele não tem a competência exigida pela lei e figurativizada na planta aprovada do imóvel.

O que faz o sujeito? Procura seu amigo, João Saracura, que é fiscal da prefeitura, para "arranjar tudo" para ele.

Tem-se a fase da manipulação entre o ST e o sujeito-fiscal, ausente da canção mas, recuperável por pressuposição.

Em Abrigo de Vagabundos, ST Destinador estabelece um contrato com o sujeito-fiscal $^{97}$ (SF) Destinatário. Nos versos "João Saracura que é fiscal da Prefeitura/Foi um grande amigo, arranjou tudo pra mim", é possível analisar o contrato sob duas diferentes perspectivas. Na primeira, o ST, através de sua amizade, e usando-a como "moeda de troca", manipula o SF. Na segunda, ST, pelo conhecimento da pessoa certa e movido pelo seu interesse, manipula o SF, que se torna um "amigo" por ser um sujeito competente, capaz de "arranjar tudo". Esta é uma manipulação por sedução ou por tentação, pois o SF, além de poder fazer o que o cargo lhe outorga, também deve querer fazer, isto é, conseguir o alvará. $O$ tipo de manipulação será por tentação se houver uma recompensa, o pagamento de propina, por exemplo. Será por sedução, se houver manifestação de um juízo positivo sobre a imagem do manipulado: ele é a pessoa certa para alcançar o objetivo.

A obtenção do alvará corresponde à performance. Neste caso, a performance é conjuntiva, de aquisição, pois o favor resulta na apropriação da maloca, que "hoje está legalizada e ninguém pode demolir".

O fato de o ST ter conseguido a maloca "mais linda deste mundo" resulta em uma sanção positiva, pois seu objetivo inicial foi alcançado: a planta da construção.

${ }^{97}$ Sujeito-fiscal, doravante SF. 
Essa sanção positiva ainda the deu possibilidade de oferecer abrigo aos amigos vagabundos, "que não têm onde dormir".

No nível discursivo, temos um texto predominantemente figurativo, remetendo a, pelo menos, cinco temas:

Tabela 2: Temas e figuras

\begin{tabular}{|l|l|}
\hline \multicolumn{1}{|c|}{ Temas } & \multicolumn{1}{c|}{ Figuras } \\
\hline Trabalho & $\begin{array}{l}\text { Arranjei o meu dinheiro/ Trabalhando o ano } \\
\text { inteiro/Numa cerâmica/ Fabricando potes/ } \\
\text { quem trabalha tudo pode conseguir }\end{array}$ \\
\hline Construção & $\begin{array}{l}\text { Comprei um lindo lote/ Construí minha } \\
\text { maloca/ }\end{array}$ \\
\hline Tráfico de influência & $\begin{array}{l}\text { Sem planta, não se pode construir/ Mas quem } \\
\text { trabalha tudo pode conseguir/ João Saracura } \\
\text { que é fiscal da prefeitura/ Foi um grande } \\
\text { amigo, arranjou tudo pra mim }\end{array}$ \\
\hline Amizade & $\begin{array}{l}\text { Por onde andará Joca e Matogrosso/ Aqueles } \\
\text { dois amigos/ A minha maloca, ofereço aos } \\
\text { vagabundos }\end{array}$ \\
\hline Crítica econômico-social & $\begin{array}{l}\text { (Aqueles dois amigos) andarão jogados na } \\
\text { avenida São João/ Ou vendo o sol nascer } \\
\text { quadrado na detenção/ (Minha maloca) Hoje } \\
\text { está legalizada ninguém pode demolir }\end{array}$ \\
\hline
\end{tabular}

A organização narrativa é temporalizada em ações do presente, é o agora, do "hoje está legalizada", "ofereço aos vagabundos", a partir do qual se organiza o antes (passado): arranjei, comprei, construí. A pessoa é a primeira eu. O espaço é o aqui, a maloca. Dessa forma, o discurso produz o efeito de proximidade, passando a ideia de subjetividade.

Analiso a situação descrita no texto, a canção Abrigo de Vagabundos, sob a perspectiva do "jeitinho". E como o mecanismo surge na canção? A partir do momento no qual o dono da maloca precisa legalizar a construção, e pede ajuda a João Saracura, que é fiscal da Prefeitura. O que o ator dono da maloca pede pode ser um favor? Pediu ao amigo que arranjasse tudo para regularizar a construção. 
Não está pagando propina, não deu "caixinha", não menciona nem uma "cerveja". Nada disso é citado.

Contudo, vejo mais de um cenário possível. Como pontuado em texto anterior, Antonico, o "favor" não é caracterizado por ser contra as normas. Porém, ao vocábulo "arranjo", cabem, de acordo com Houaiss, pelo menos dez acepções. Nele encontramos três possibilidades que podem, eventualmente, ligá-lo ao "jeitinho": "acordo de conveniência entre pessoas; acordo entre pessoas para lesar ou enganar outras; auxílio obtido à custa de pessoa influente". O acordo de conveniência pode ser encarado como o que menos apresenta característica de lesar, de causar prejuízo. No entanto, o ato de "arranjar", que inclui lesão a outros caracteriza desvio de obrigações legais, enquanto o uso de pessoas influentes, poderá ou não caracterizá-lo. A concessão ou o arranjo do ator fiscal, se inclui lesão, é contra a lei: resulta em prejuízo para os cofres públicos e é um ato que se constitui ilícito para o funcionário público. Tal ação é definida como prevaricação ${ }^{98}$ e está inserida como crime no Código Penal brasileiro, sob artigo $319^{99}$.

O fiscal, para fazer o favor para o amigo, no afã de "arranjar tudo para ele", "dá um jeito", procura solucionar um problema (seja por meios usuais ou alternativos) tomando as providências necessárias (Aulete). Porém, quando "faz vista grossa" para o ilícito, incorre em ato de prevaricação, que resulta em uma ação de corrupção.

Afinal, João Saracura é corrupto e comete crime ou "dá um jeitinho", fazendo um "favor"?

Sobre a questão dos tipos de "jeitinho", o professor americano de Direito, da Universidade de Ohio, Keith S. Rosenn, em trabalho sobre o "jeito”, apresenta pelo menos cinco tipos diferentes de comportamento a ele identificados, que ocorrem associados a funcionários públicos. O principal deles seria:

\footnotetext{
${ }^{98}$ Prevaricar, segundo Houaiss, seria faltar ao cumprimento do dever por interesse ou má-fé; cometer abuso de poder, provocando injustiças ou causando prejuízo ao Estado ou a outrem; transgredir a moral e os bons costumes; cometer adultério revelar segredo que Ihe foi confiado; trair a confiança; corromper, perverter.

${ }^{99}$ Código Penal Brasileiro - Decreto Lei no 2.848 de 07 de Dezembro de 1940

Art. 319 - Retardar ou deixar de praticar, indevidamente, ato de ofício, ou praticá-lo contra disposição expressa de lei, para satisfazer interesse ou sentimento pessoal: Pena - detenção, de três meses a um ano, e multa.
} 
Quando um funcionário público se desvia de sua obrigação legal por razão de ganhos pecuniários ou status (como a família, ou o círculo de amizades). Por exemplo, quando um contrato com o governo é concedido em troca de uma alta propina (ROSENN, 1971, p. 515, tradução nossa).

De acordo com o que propõe Rosenn (1971), o que ocorre em Abrigo de Vagabundos pode ser um "jeitinho". Para se afirmar junto aos amigos, ter reconhecimento, se gabar da sua posição, o funcionário público seria capaz de driblar a lei. O problema que o autor destaca é que tal comportamento é desonesto, e beneficia o indivíduo às custas do Estado. E este é o conceito de corrupção. $O$ ponto de vista apresentado pelo pesquisador coincide com o que se encontra na lei como prevaricação.

Há, segundo o mesmo autor, outro comportamento, pelo qual o funcionário público atua contra os princípios da lei, se desvia de suas obrigações legais, por acreditar que as normas são injustas, irreais e supérfluas, e age de forma a atender os objetivos públicos, em detrimento das normas estabelecidas. Ainda segundo Rosenn (1971), esse comportamento, do ponto de vista moral, está mais próximo de ser visto como "jeito" do que o primeiro, que pode ser identificado mais com a corrupção.

Esse modo de entender poderia ser o que o amigo fiscal tinha em mente. Não seria justo para com o dono da construção nem com outras pessoas na mesma situação que suas habitações fossem demolidas. Assim, João Saracura pode ter ignorado a irregularidade e arranjado o alvará para o amigo viver tranquilo em sua maloca. Ou ainda, pode simplesmente ter usado seu conhecimento sobre os trâmites para encaminhar a documentação e agilizar sua regularização.

Mas, e quando se analisa pelo ponto de vista do trabalhador, ainda sem nenhuma intervenção, que construiu sua maloca sem licença, que se há de fazer? Derrubar? Se a área na qual ele construiu não for passível de receber aprovação legal à sua construção, provavelmente todas as outras construções à sua volta também estão irregulares. Vai derrubar tudo? E a questão social? Será que o Estado releva e dá um "jeitinho"?

Para se dar uma possível resposta satisfatória a essa questão, analisemos um ponto apresentado por Roberto Campos (1966), em A sociologia do jeito ${ }^{100}$.

${ }^{100}$ In: A técnica e o riso. CAMPOS, Roberto de O., 1966, p. x. 
autor apresenta como uma das explicações para não existir "jeitinho" nos países anglo-saxões, a

[...] diferença de atitudes entre latinos e anglo-saxões no tocante às relações entre a lei e o fato social. Para o empiricismo jurídico anglo-saxão, a lei é muito menos uma construção lógica que uma cristalização de costumes (CAMPOS, 1966, p. XVII).

Assim, para os anglo-saxões, a lei codifica os costumes correntes. Uma lei raramente é inexequível. Já para nós, latinos, há um descompasso entre o fato social e as leis. Ainda segundo o autor, "as Constituições de tipo latino são miudamente normativas e regulamentares" (CAMPOS, 1966, p. XVI) e esse descompasso nos leva a modificá-las seguidamente. E acrescenta que "dentro do formalismo jurídico latino, frequentemente o descumprimento da lei é uma condição de sobrevivência do indivíduo, e de preservação do corpo social sem inordinato ${ }^{101}$ atrito" (p. XVII).

Dessa forma, qual a resposta para a pergunta, o que fazer com a maloca erguida irregularmente? O que deve acontecer? Vemos, como justificativa para que a maloca permaneça erguida, que a lei, quando descolada dos mais pobres, tornase cruel e desumana, e perde para os valores da sobrevivência. No embate entre os "dois brasis", o da lei e o da vida, se para viver é preciso burlar a lei, o "jeitinho" torna-se justificável, até mesmo necessário.

\subsection{Jeitinho Brasileiro em uma canção: hipocrisia e corrupção... Não tem jeito?}

O "jeitinho brasileiro" pode ser analisado, ao menos, sob três aspectos: como mecanismo de navegação social, como elemento de identidade nacional ou do ponto de vista de sua significação, em resposta à questão "o que torna o 'jeitinho brasileiro' o 'jeitinho brasileiro'?".

Responder à questão proposta exige atentar-se a seu teor de estratégia de navegação social, mas, sobretudo, aos valores que no discurso social e na mídia o definem como marca da constituição da identidade do "brasileiro", assumida e

\footnotetext{
101 Inordinato (ingl): inordinate: beyond proper or normal limits; excessive: an inordinate amount of time/space/money (Oxford Advanced Learner's dictionary).
} 
experienciada dentro de uma espécie de "pacto ou contrato social" ${ }^{102}$ subvertido, uma vez que o "jeitinho" visa frequentemente o esvaziamento do poder da lei como soberana.

Em sua ampla abrangência e com relativo grau de adesão, o "jeitinho" é aceito com certa simpatia e tolerância em relação ao modo de ser do brasileiro. É associado à criatividade e flexibilidade, à simpatia e à generosidade alheia.

Por outro lado, expressa a dificuldade desse brasileiro estereotípico em relação ao respeito às leis, às instituições e ainda à hierarquia, temas cuja abordagem é complexa na contemporaneidade ${ }^{103}$.

Essa é considerada uma abordagem negativa para o "jeitinho", e é normalmente associada à "esperteza", à "malandragem" e à corrupção. É a partir desse aspecto que desenvolvo a análise deste subcapítulo.

Retomo o vocábulo "jeitinho", que, como já exposto anteriormente, apresenta uma série de oposições, como o "jeitinho" que se opõe ao jeito que é modo, se opõe à malandragem no "bom sentido", e também se opõe à maneira delicada. A escolha do corpus para análise da parassinonímia, em capítulo anterior, incidiu sobre canções. Ao analisar o "jeitinho", associado ou remetendo à corrupção, julguei adequado utilizar a canção que se vê abaixo, pois o tema apresenta certa amplitude e complexidade. Assim, procuro não enveredar por questões e paixões políticoideológicas, que constituiriam verdadeiras armadilhas.

Escolhi a canção Jeitinho Brasileiro ${ }^{104}$, de autoria de Juliana Eleutério, interpretada pela banda Rock Roach, formada por garotas catarinenses, em 2009. Havia também músicas conhecidas, de autores ou intérpretes consagrados, porém, optei pela composição de uma jovem que integra um grupo ainda sem projeção.

\footnotetext{
102 O estado de natureza de Hobbes e o estado de sociedade de Rousseau evidenciam uma percepção do social como luta entre fracos e fortes, vigorando a lei da selva ou o poder da força. Para fazer cessar esse estado de vida ameaçador e ameaçado, os humanos decidem passar à sociedade civil, isto é, ao Estado Civil, criando o poder político e as leis. A passagem do estado de natureza à sociedade civil se dá por meio de um contrato social, pelo qual os indivíduos renunciam à liberdade natural e à posse natural de bens, riquezas e armas e concordam em transferir a um terceiro - o soberano - o poder para criar e aplicar as leis, tornando-se autoridade política. O contrato social funda a soberania (CHAUI, 2000, p. 220).

${ }^{103}$ Sobre esta problemática, Bauman (2001) cita Alexis de Tocqueville: "O indivíduo é o pior inimigo do cidadão" (...). O "cidadão" é uma pessoa que tende a buscar seu próprio bem-estar através do bem estar da cidade - enquanto o indivíduo tende a ser morno, cético ou prudente em relação à "causa comum", ao "bem comum", à "boa sociedade" ou à "sociedade justa" (BAUMAN, 2001, p.45). ${ }^{104}$ Disponível em: <http://letras.mus.br/rock-roach/1659684/>. Acesso em: 2 jul. 2013.
} 
que ela escreve parece estar próximo do que anda povoando a cabeça da maioria dos jovens, principalmente na história recente e presente, em que as multidões vão às ruas, com diferentes bandeiras e clamores, tudo permeado por uma indignação frente às denúncias de corrupção. Outras canções que citam o "jeitinho brasileiro" normalmente o fazem se referindo à malemolência, àquele jeito de falar ou moverse, ou ainda, remetem à saudade da terra natal. Eis a letra da canção escolhida:

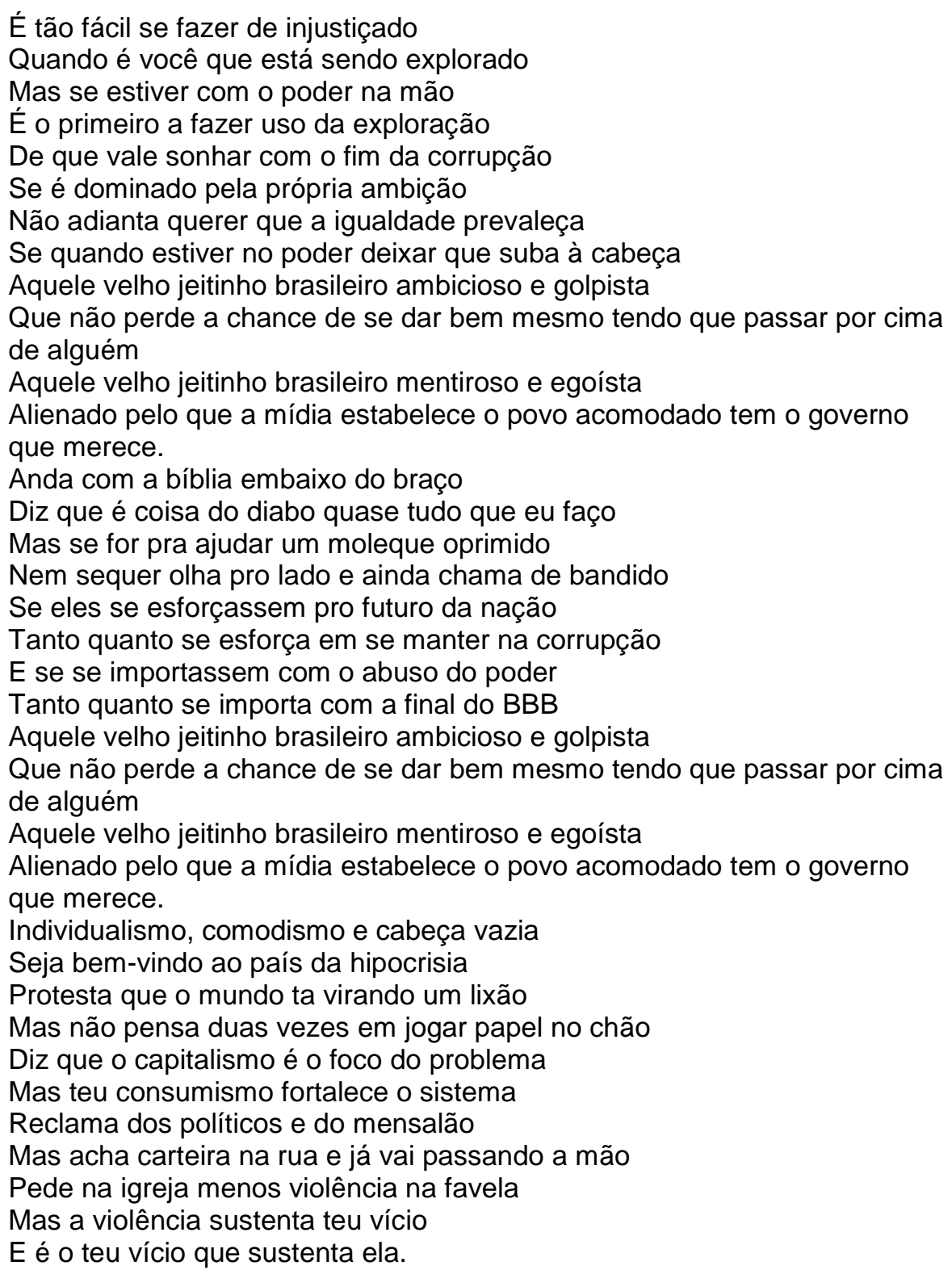

Inicio a análise da letra da canção Jeitinho Brasileiro pelo estudo dos percursos temáticos e figurativos e da sintaxe discursiva (pessoa, tempo e espaço). 
A canção é um texto predominantemente temático sobre a relação entre o "jeitinho brasileiro" e a hipocrisia ${ }^{105}$, construído pelas figuras relativas aos usos do "jeitinho" pelos brasileiros. Vejamos como tal relação é construída.

Em primeiro lugar, o sujeito "brasileiro":

- se faz(er) de injustiçado

- (ter) o poder na mão

- faz(er) uso da exploração

- (ser) dominado pela própria ambição

- deixa(r) que o poder suba à cabeça

- (ser) velho, ambicioso e golpista

- não perde(r) a chance de se dar bem

- passa(r) por cima de alguém

- (ser) velho, mentiroso e egoísta

- (ser) alienado pela mídia

- se importa(r) com a final do BBB

- (ser) povo acomodado

- (ter) o governo que merece

- se manter na corrupção

- (ser) individualista, comodista

- (ter) a cabeça vazia

- (ser) país da hipocrisia

- joga(r) papel no chão

- (ser) consumista

- fortalece(r) o sistema

- $\operatorname{passa(r)~a~mão~na~carteira~(que~acha~no~chão)~}$

- violência que sustenta o vício

- (ter) o vício que sustenta a violência (e a favela).

${ }^{105} \mathrm{~A}$ hipocrisia é uma homenagem que o vício presta à virtude. (François La Rochefoucauld). Hipocrisia, segundo Houaiss, é o ato ou efeito de fingir, de dissimular os verdadeiros sentimentos, intenções; fingimento, falsidade. Ainda, caráter daquilo que carece de sinceridade. 
Todas essas figuras presentes na canção combinam-se num quadro em que o sujeito brasileiro retratado é mentiroso (se faz de injustiçado), ambicioso, golpista e, tendo a oportunidade, torna-se explorador, além de ser alienado, acomodado, individualista, de cabeça vazia, consumista e viciado, enquanto está pronto para se manter na corrupção, apoderar-se do que não é seu e sustentar a violência para conservar seu prazer ou vício.

Um sujeito, enfim, que elege como valor maior o "se dar bem" e para quem o "outro" só tem valor como meio de sua satisfação imediata (de poder, de opressão, de entretenimento, de enriquecimento).

Esse sujeito, não nos esqueçamos, é mentiroso, o elo para a hipocrisia. A canção evidencia um sujeito contraditório, apresentando incoerência entre o que ele diz e o que faz, o modo como deveria agir, e como são, de fato, seus atos. Em alguns trechos temos a explicitação dessa incoerência. Ei-los:

- Anda com a bíblia embaixo do braço vs diz que é coisa do diabo quase tudo que eu faço.

- Mas se for para ajudar um moleque oprimido vs nem sequer olha pro lado e ainda chama de bandido

- Se esforçar pro futuro da nação vs se esforçar em se manter na corrupção

- Se importar com o abuso do poder vs se importar com a final do BBB

Tais contrastes sugerem um simulacro que oculta uma realidade diferente. Ou seja, pode-se estabelecer uma relação entre o "jeitinho brasileiro" e a hipocrisia: fingir fazer a coisa certa, o que é considerado ético, em oposição às ações que revelam um lado oportunista.

Assim, como indicam os versos destacados abaixo, é possível associar o caráter mentiroso à hipocrisia e apresentar o "jeitinho" como a forma socialmente difundida de articulação dos valores que possibilita a ação hipócrita.

- Aquele velho jeitinho brasileiro ambicioso e golpista

- Que não perde a chance de se dar bem mesmo tendo que passar por cima de alguém

- Aquele velho jeitinho brasileiro mentiroso e egoísta 
- Alienado pelo que a mídia estabelece o povo acomodado tem o governo que merece.

Vejamos a sintaxe discursiva, as categorias de pessoa, tempo e espaço.

$O$ enunciador é aquele que acusa, aponta o dedo e fala das mazelas do "jeitinho". Fala com um interlocutor, o enunciatário, que é o sujeito usuário do "jeitinho", o que reclama, mas dele faz uso. O velho "jeitinho" é recurso empregado por aquele a quem a canção fala.

$\mathrm{Na}$ canção, temos o ator eu, o enunciador, que se faz presente, por exemplo, quando reclama das pessoas que andam com a bíblia debaixo do braço/ que dizem que é pecado quase tudo que eu faço. $\mathrm{O} t u$, o enunciatário, que é com quem o eu fala, é quem ataca as mazelas, mas, na primeira oportunidade, usufrui das benesses, esquece as origens, oprime outrem e mantém seu vício, sustentando a violência na favela, por meio do "jeitinho brasileiro".

O "jeitinho brasileiro" é o tema principal de que se fala, que é velho, ambicioso, golpista, mentiroso, egoísta, alienado, acomodado. Outros de quem se fala consistem no "povo", no "moleque oprimido", mas também naquele que não se esforça "pro futuro da nação/ tanto quanto se esforça em se manter na corrupção" nem se importa "com o abuso do poder/ tanto quanto se importa com ao final do BBB": em suma, o "país da hipocrisia".

O lugar é o aqui, o país, onde todas as ações se desenrolam.

O tempo é o presente, o agora, em que o sujeito se faz de injustiçado, em que é dominado pela ambição, protesta, pensa, reclama.

Tendo-se identificado os temas predominantes "jeitinho brasileiro" e "hipocrisia", que trazem a reboque, pela ausência, a igualdade e justiça social para o futuro da nação, passemos agora à análise narrativa da letra da canção.

$O$ texto da canção apresenta um esquema narrativo composto pela repetição de um mesmo programa narrativo mínimo, cujas fases são recuperadas por pressuposição: manipulação, transformação e sanção.

No nível da comunicação dos valores, tem-se o Destinador (D1) como dotador de valores compatíveis com o exercício da cidadania, e o antidestinador (D2), como dotador de valores compatíveis com o exercício do "jeitinho". 
No nível da ação, teremos uma manipulação por provocação, em que S1 é o sujeito que se associa aos valores de D1, na pessoa do eu. S2 é o sujeito cuja ação S1 almeja transformar, na pessoa do tu/você. O objeto valor (Ov) ao qual S2 está conjunto é o "jeitinho brasileiro".

Projetando a S2 uma imagem fortemente negativa, S1 procura fazê-lo querer abandonar o "jeitinho" e assim conquistar uma imagem positiva, segundo os valores de S1.

É necessário observar, porém, que o "jeitinho brasileiro" não é o valor maior almejado, mas consiste num meio para S2 "se dar bem". Trata-se, portanto, de um programa de uso, comparável, nos contos maravilhosos, a uma conquista intermediária, como uma chave especial ou uma poção mágica, que possibilitam a realização do objetivo maior.

$\mathrm{Na}$ canção, os enunciados "se fazer de injustiçado", "fazer uso da exploração", "ser dominado pela própria ambição", revelam algumas figurativizações do objeto modal. O sujeito S2 está em conjunção com esses objetos, apresentados em um quadro de valores majoritariamente negativo, sob a ótica de $\mathrm{S} 1$ (e, ao menos superficialmente, também de $\mathrm{S} 2$, quando protesta e reclama).

S1 procura manipular S2 por provocação, isto é, projetando-Ihe a imagem de hipócrita, da qual pode se livrar, se agir diferentemente. Se S2 abandonar o "jeitinho brasileiro", deixará de ser hipócrita e participará da construção de uma nação mais igualitária e justa.

Espera-se, então, uma transformação (almejada). O S1, o sujeito do fazer fazer, quer o abandono do "jeitinho" em prol de um país mais justo, mais igual. O S2 é o sujeito do fazer, usuário do "jeitinho", e que teria o poder (e precisa ter o querer) mudar, para abdicar do "jeitinho" e dos vícios a ele associados.

O sujeito enunciador, associado a D1, tenta fazer com que seu enunciatário, S2, associado ao antidestinador D2, convença-se a abandonar o "jeitinho brasileiro" e, consequentemente, passe a fazer uso de valores de igualdade e justiça social.

$\mathrm{Na}$ instauração da competência, temos o S2 que pode fazer e sabe fazer.

Porém, a performance desenvolvida por S2 é a oposta da desejada por S1. S2, quando faz uso do "jeitinho" encontra certas facilidades que não são concedidas a todos. Então, ele escolhe um querer não fazer. 
S2 age no sentido de que, com as escolhas que faz, ao lançar mão do "jeitinho brasileiro", haja uma aquisição de poder em desacordo com a justiça, como "passar por cima de alguém", ignorar um "moleque oprimido", negar-lhe ajuda e "ainda chamá-lo de bandido".

É uma performance hipócrita, pois, enquanto S2 fica em conjunção com todos os vícios associados ao "jeitinho", suas palavras clamam por justiça, que ele mesmo boicota pela satisfação de suas escolhas. A letra destaca a incoerência de quem reclama dos problemas, mas age de forma contrária ao que diz.

A performance proposta por S1 não se concretiza: há um reconhecimento da não realização. A sanção do Destinador julgador, diante das opções e das escolhas feitas, será negativa, pois S1 não consegue conter a escalada de S2 no sentido de se "dar bem", obtida à custa do uso dos vícios do "jeitinho brasileiro".

Pode-se identificar a sanção, principalmente, a partir do trecho "Seja bemvindo ao país da hipocrisia", à medida em que S2 protesta, mas age ao contrário; diz uma coisa e faz outra; reclama, mas faz algo do qual está reclamando. Pede menos violência, mas a violência sustenta o "seu" vício e o "seu" vício sustenta a violência. É um círculo vicioso.

Ocorre, então, um reforço de uma identidade negativa, que S1 tenta conter, associada ao abuso de poder, à corrupção e seus vícios.

A postura crítica das pessoas em relação ao "jeito" o aproxima da corrupção, tornando a visão do mecanismo mais negativa. Nesse discurso negativo sobre o “jeitinho", podem-se distinguir dois tipos, segundo Barbosa (2006): um deles teórico ou erudito e outro popular. Podemos identificar ambos os discursos na letra da canção. Ainda conforme a autora,

\footnotetext{
De modo geral, o discurso teórico ou erudito sobre o jeitinho se baseia na reflexão crítica sobre as nossas instituições sociais, a nossa realidade econômica e o conceito do que é o Brasil como nação. [...] É também um discurso de denúncia. Denúncia de nossas instituições sociais e políticas carentes de credibilidade e da nossa herança ibérica. Denúncia de nossos homens públicos, da corrupção e da impunidade (BARROS, 2006, p. 74).
}

É um discurso que prega que as coisas aqui não funcionam, não são sérias. Em relação à caracterização do povo brasileiro, as tão decantadas qualidades brasileiras, como a cordialidade, a simpatia, serviriam para manipulação das classes 
oprimidas e haveria necessidade de um trabalho de conscientização das massas para que deixassem este estado de alienação. É o discurso que apresenta o povo brasileiro em duas versões, a pública, que o descreve como sofrido, trabalhador, mas no âmbito privado, o tacha de mal-educado, pouco sério, picareta, preguiçoso. Diz que o Brasil tem muitas possibilidades, mas que está fadado ao fracasso, "se as coisas se mantiverem como estão".

Já o discurso negativo popular é produto da vivência dos seus autores - 0 que se ouve, e é corrente - manifestação de frustrações quanto às expectativas em relação ao país, ao governo ou ao povo. Não é fruto de análises elaboradas da nossa realidade. Manifesta uma descrença no futuro do país, nas atitudes de sua gente, nas instituições, associada a certa resignação, como se não fosse possível mudar. Poderia ser resumido em um: "Infelizmente é assim... Não tem jeito..."

\subsection{Leitura do jeitinho brasileiro por estrangeiros}

Relato do jornalista Clóvis Rossi sobre fato ocorrido na Holanda, em jantar oferecido pela rainha Beatrix ao, então, presidente Lula.

Em crônica publicada na seção Opinião, da Folha de São Paulo, de 13 de abril de 2008, intitulada Jeitinho não basta, o jornalista Clóvis Rossi, escreve, de Haia, Holanda, relatando que o Itamaraty promoveria um encontro da diáspora brasileira $^{106}$, ainda naquele ano. A convocação do encontro teria por objetivo conhecer as necessidades e dificuldades enfrentadas pelas comunidades brasileiras espalhadas pelo mundo.

O jornalista relata ainda que, "até a Holanda, país pequeno e de língua esquisita", conta com 11.000 brasileiros, legalizados, em um universo de 50.000 falantes de português (à época), e que há inclusive uma rádio em português, "Pulsa Brasil FM in the Netherlands".

O fato importante que o jornalista acompanhava era o almoço que a rainha Beatrix oferecia ao, então, presidente Lula.

\footnotetext{
${ }^{106}$ Os anos 1980 foram marcados por um forte afluxo de emigrantes brasileiros para os Estados Unidos, Canadá, Japão e Europa ocidental. Nota-se que, ao contrário dos seus antepassados que, na grande maioria, era despossuída de bens e fugia de conflitos, os brasileiros que optaram por deixar o país nesta época, também eram oriundos das classes média e média-alta, e buscavam escapar de um país que não oferecia oportunidades econômicas (IRIGARAY et al., 2013, p. 1).
} 
Os garçons do bufê contratado (que, a propósito, eram em sua maioria caboverdianos) "deram o popular jeitinho de contrabandear sanduíches para os jornalistas que entravam para a sala do trono pela porta dos fundos".

Rossi (2008) acrescenta:

\begin{abstract}
Brasileiro adora esse "jeitinho", tanto que, na tradução do discurso do primeiro-ministro Jan Peter Balkenende nesse almoço, havia um elogio ao "otimismo e ao jeito" do brasileiro. Pena que, na fala em inglês, Balkenende usou "hability" (sic), talvez por não haver "jeitinho" em inglês ou holandês. Por isso, é bom mesmo ouvir a diáspora, que jeitinho só não basta. (ROSSI, 2008)
\end{abstract}

Nessa crônica, o jornalista aborda dois pontos importantes, para esta pesquisa. O primeiro deles, já presente no título do artigo, é o "jeitinho". O segundo, refere-se à questão da tradução do vocábulo. O fato de o primeiro-ministro ter usado "ability" quando teceu elogios ao "otimismo e ao jeito" do brasileiro, suscitou um lamento da parte do articulista, embora pareça não ter causado espanto, pois argumenta que '[...] Balkenende usou 'hability' (sic), talvez por não haver 'jeitinho' em inglês ou holandês" (ROSSI, 2008).

O autor, em seu comentário, estaria reforçando a ideia de que só o brasileiro possui o "jeitinho"?

O "jeitinho" não é exclusividade brasileira. Rosenn (1971) escreve que seria um termo não passível de tradução, e que corresponderia, grosso modo, a 'knack', 'twist', 'way' ou 'fix', em inglês. Atesta inclusive, que, nos meios advocatícios, nos Estados Unidos da América, forma de agir semelhante ao "jeitinho" é conhecida e pode ser atestada por quem trabalha em causas relacionadas a divórcio ou inventa minutas para reuniões de acionistas que não existiram em pequenas companhias ou, ainda, envolve-se em barganhas, negociando acordos em casos criminais ${ }^{107}$.

Duarte (2006) enumera algumas formas similares do "jeitinho" em outras culturas: trinkgel, na Alemanha; bustarela, na Itália; speed money, na Índia; backsheesh, no Egito; mordida, no México; vizyatha, na Rússia; chtara, na Argélia; palanca, na Colômbia; pituto, no Chile, e guaperia, em Cuba. Segundo a autora, a

\footnotetext{
${ }^{107}$ The functional equivalent of the jeito is well known in the United States, as any lawyer who handled an uncontested divorce, invented the minutes of fictitious meetings of shareholders in small corporations, or engaged in plea bargaining in criminal cases will attest. Indeed, the keystone of American constitutional law, Marbury $v$. Madison, is a classic example of the utility of bending norms expediency (ROSENN, 1971, p. 515).
} 
despeito de um estudo cultural mais aprofundado em relação às similaridades entre as expressões, poderia se especular que a diferença estaria entre a 'escolha social' ou o 'peso social' que a sociedade brasileira atribui ao "jeitinho".

O brasileiro, ao ser chamado a descrever seu país e seu povo, recorre ao "jeitinho brasileiro" quase que espontaneamente, pois, normalmente, ele é utilizado como sendo uma forma particular de falar sobre o país, da sua gente e de como atua diante de determinadas situações de uso desse mecanismo.

Quando o jornalista fala sobre o jeitinho em seu artigo, quais expressões ele usa, e que conotação dá a esses "jeitinhos"? Vejamos:

\footnotetext{
- "o popular jeitinho de contrabandear sanduíches para os jornalistas";

- "brasileiro adora esse 'jeitinho"';

- "talvez por não haver 'jeitinho' em inglês ou holandês";

- "jeitinho só não basta".
}

A primeira característica que o autor atribui ao "jeitinho" é popular. vocábulo pode ter a conotação de que é "encarado com aprovação ou afeto pelo público em geral" (Houaiss). Se por um lado o significado traz consigo um sentido positivo, o autor associou o popular "jeitinho" a contrabandear, que em seu sentido figurado e uso informal, seria um "ato irregular ou praticado às escondidas" (Houaiss). O jornalista parece pontuar que essa é uma das funções do "jeitinho": associar a aprovação e o afeto do público com o ilícito.

Em seguida, ao dizer que o brasileiro adora esse "jeitinho", reitera o conceito de que conta com a aprovação e simpatia das pessoas, o que favorece ainda mais o seu uso. As pessoas usam-no porque gostam muito e não sentem nenhum embaraço pela sua atitude. Também, se as pessoas o adoram, de certa forma, sua adesão ocorrerá mais fácil e naturalmente.

Por outro lado, ao relatar que talvez não haja "jeitinho" em inglês ou holandês, pode soar como um comentário preconceituoso: povos de países do primeiro mundo não utilizariam um recurso de forma a associar algo que apresentasse alguma irregularidade, o que torna difícil a sua tradução, pois não há similar, ou outro elemento de comparação.

E finalmente, com "jeitinho" só não basta, teria o sentido de "não ser bastante ou suficiente" (Houaiss). No que tange ao emigrante brasileiro, esse indivíduo "viveu experiências novas, travou contato com outros sistemas de pertinência, outros 
códigos culturais" (Irigaray et al., 2013, p. 1) e, provavelmente, não tem o "jeitinho" como recurso, muito menos como o único. Em relação aos que emigraram para os Estados Unidos, "as comunidades buscam o respeito à sua integridade e dignidade humana e o direito, não o privilégio, de sonhar e buscar seus ideais" (Silva, 2008). Pode-se dizer que quem tem tais aspirações, não deve e nem pode se fiar no "jeitinho". As dificuldades que os emigrantes enfrentam não são passíveis de solução com o uso do mecanismo. Para conseguir espaço e reconhecimento e fugir da estigmatização e do preconceito, eles têm de mostrar seu valor. De certa forma, o jornalista mostrou certa falta de confiança em nossos conterrâneos que se encontram em outras paragens. Ou, talvez, esteja sugerindo que as instituições que normalmente dão algum aparato legal às pessoas que fazem parte da diáspora, como o Itamaraty, por exemplo, precisam ouvi-las, conhecer seus problemas, garantir sua sobrevivência para poderem levar uma vida decente. Eles precisam saber que podem contar com o apoio de seu governo, mesmo distante de seu país, e as autoridades competentes que devem, sim, saber que ali, o jeitinho só não basta.

A pequena amostra do uso do vocábulo "jeitinho" em trecho da crônica de Rossi (2008) permite a verificação de que é possível lhe imputar conotação tanto positiva quanto negativa.

Em seguida, discuto brevemente a questão da tradução, que terá um tratamento mais aprofundado adiante (p. 161).

Partindo-se do princípio de que cada signo de cada língua remete a um campo semântico peculiar e que, normalmente, não há uma tradução pacífica de uma língua para outra, o vocábulo "jeitinho", com todos os seus parassinônimos, não passaria incólume.

Em relação ao lamento do jornalista sobre o uso de 'ability' na tradução feita pelo primeiro-ministro holandês para se referir ao "jeitinho", Discini (2009) tece o seguinte comentário:

"Hability", usado pelo político holandês, não tem o mesmo valor que "jeitinho"; este último termo, na língua portuguesa, tem um valor que somente se depreende da observação das relações imanentes, estabelecidas por nosso idioma, em que existe esta oposição categorial: jeitinho (o popular "jogo de cintura") versus falta de jeito (rigidez do comportamento). A língua portuguesa estabelece arbitrariamente as 
fronteiras que permitem emergir o tal conceito de jeitinho aludido na crônica (DISCINI, 2009, p. 598).

Depreende-se que, de fato, a tradução não foi satisfatória. "Ability" e "jeitinho" não têm o mesmo valor. Em sua defesa, o ministro poderia alegar que entre as definições de "jeito" encontram-se no Houaiss: capacidade especial; arte, destreza, habilidade. Já "ability", no Merriam-Webster, significa the power or skill to do something, e desde as nossas primeiras lições de inglês, aprendemos a correspondência com o modal $C A N$, que expressa a capacidade e habilidade de se fazer algo. Por esse viés, haveria certa convergência de significados.

Porém, como expresso por Discini (2009), "da observação das relações imanentes" constatamos a existência de outras oposições categoriais, como o "jeitinho" assemelhado ao 'favor' versus o "jeitinho" de 'tirar vantagem', de se dar bem. Haveria, ainda, o "jeitinho" como traço cultural.

Assim, "ability" como habilidade no sentido de "ser capaz de..." é muito limitado para a vasta possibilidade de significados do "jeitinho". Vejamos outros exemplos de uso e se encontramos uma tradução mais plausível.

Inicialmente, apresento um artigo escrito pelo editor da Revista Língua Portuguesa, Pereira Júnior, e publicado em março de 2013. Chamou a atenção a indignação causada ao editor pela tradução feita do "jeitinho" como "little way"108, por um influente blog sobre economias emergentes, o Beyond Brics do jornal britânico Financial Times (FT). $\mathrm{O}$ articulista assim justifica seu inconformismo com a escolha lexical: "Virou produto de exportação a secular confusão entre jeitinho brasileiro, o traço cultural, e o improviso com cara de trapaça, trivial em qualquer país". A colunista do blog, Samantha Pearson, em seu texto postado em 15 de janeiro de 2013, sob o título Brazil's monetary jeitinho, refere-se a manobras contábeis de que - Tesouro Nacional teria se utilizado para que o país cumprisse a meta fiscal de 2012. E acrescenta que o Ministro da Fazenda, Guido Mantega, seria um expert, um

\footnotetext{
${ }^{108}$ If there's one Portuguese word you need to learn before coming to Brazil it's jeitinho. Literally "little way", it refers to the nationwide habit of circumventing rules or conventions through highly creative, cunning and sometimes downright illegal tactics. Can't get tickets to a show or pass your driving test? Don't worry; you just need to find a jeitinho. It also works for managing the economy, it seems (PEARSON, 2013).
} 
profissional do "jeitinho". Pearson define o "jeitinho" (little way) como "o hábito nacional de negligenciar ou driblar as regras ou convenções através de táticas extremamente criativas, astutas, e algumas vezes, absolutamente ilegais" (tradução nossa).

Por que se dá esse tipo de leitura?

De certo modo, há de se concordar que a interpretação do "jeitinho" é árdua, pela polissemia, inclusive para nós, brasileiros. Tal fato, inclusive, justificou minha pesquisa.

Por outro lado, a articulista cede à tentação e recorre ao estereótipo que circula em depoimentos de estrangeiros sobre o nosso povo. Segundo Tavares (2013), que escreve sobre as qualidades e defeitos da condição de ser brasileiro, em artigo complementar ao de Pereira Júnior,

As críticas que nos fazem são sempre parecidas, todas sobre coisas que a gente já sabe e, em certa medida, são verdadeiras: o brasileiro é acomodado, não se mobiliza socialmente para protestar, é excessivamente informal e despreza os instrumentos de controle (leis, Constituição, regulamentos, etc.) (TAVARES, 2013, p. 20).

Em seu argumento, Tavares, de certa forma, aceita o estereótipo. Assim, há algumas definições que reforçam a conotação positiva ou negativa, dependendo da situação e do tipo de discurso adotado.

Como exemplo da vertente que aponta o "jeitinho" como algo negativo, encontra-se a definição apresentada por Almeida (2007), a partir dos dados fornecidos pela Pesquisa Social Brasileira (PESB), empreendida pela DataUff, da Universidade Federal Fluminense, em 2002

\footnotetext{
O jeitinho brasileiro é importante em nossa sociedade. Não apenas por ser muito difundido, mas principalmente pelo fato de nos permitir entender por que o Brasil tem tanta dificuldade em combater a corrupção. [...] Os brasileiros têm a chance de saber por que a "cultura da corrupção" é tão enraizada entre nós. A PESB mostra que isso acontece porque a corrupção não é simplesmente a obra perversa de nossos políticos e governantes. Sob a simpática expressão "jeitinho brasileiro" ela é socialmente aceita, conta com o apoio da população, que a encara como tolerável (ALMEIDA, 2007, p. 45).
}

As muitas menções ao "jeitinho" ligado à corrupção vêm reforçar o enfoque dado pelo estrangeiro em relação à sua ilegalidade. Barbosa (2006) o apresenta como uma forma de lidar com problemas globais e, apesar de colocá-lo em um eixo 
que permite identificá-lo de forma positiva, aponta que tal definição dependerá do contexto histórico:

[...] dispositivos como o "jeitinho" contêm parte do estoque de respostas "locais" que a sociedade foi capaz de formular para lidar com problemas globais e universais que the foram impostos. Se a proximidade maior do jeitinho é com a corrupção, isso decorre justamente do contexto histórico em que vivemos (BARBOSA, 2006, p. xiii).

Há de se salientar que Barbosa, além de apresentar o "jeitinho" no seu viés positivo e negativo, também o aponta como elemento de identidade nacional. $A$ autora, em definição que poderia ter servido de base, pelo seu viés, para a escrita do $F T$, expõe-nos pelo nosso lado meio Macunaíma, meio Leonardo Pataca, o do malandro, entre outros:

\begin{abstract}
Usamo-lo como símbolo de nossa desordem institucional, incompetência, ineficiência e da pouca presença do cidadão no nosso universo social, louvando, assim, o nosso "atual, moderno e irreversível" compromisso com a ideologia individualista ou como emblema de nossa cordialidade, espírito matreiro, conciliador, criativo, caloroso, reafirmando nosso eterno casamento com uma visão de mundo relacional (BARBOSA, op. cit., p.175).
\end{abstract}

Face às definições e reflexões acerca do "jeitinho" aqui discutidas, creio que seja difícil condenar ou mostrar indignação perante a leitura apresentada pelo jornal inglês. Como o "jeitinho" não impõe escolha excludente e definitiva, tem-se toda essa gama de opções que, dependendo da circunstância e de quem o avalia, desperta de paixão a ódio.

Concentremo-nos no trecho da crônica de Rossi (2008) que se refere ao trabalho dos garçons durante a recepção, e sua interação com os jornalistas que cobriam o evento.

A cena é construída com recurso às figuras: sala do trono, rainha, presidente, primeiro-ministro, recepção, figuras que remetem ao tema da política, do poder. Paralelamente, surgem a porta dos fundos da sala do trono, os garçons, os jornalistas, servir sanduíches, remetendo ao tema dos serviços e serviçais. Contrapondo, temos o tema do poder, da hierarquia e, sobretudo, da divisão de classes.

No que tange às ações, aprendemos que a Casa Real contrata os serviços de um bufê que dispõe de garçons falantes da língua portuguesa. A incumbência do 
bufê contratado era a de servir os visitantes (brasileiros) e demais convidados. Os garçons, coerentemente com seu papel temático, cumprem com sua função, servindo os convidados. Tudo corre segundo previsto, ao menos inicialmente.

Os garçons, porém, servem também sanduíches aos jornalistas, que não eram convidados e que entraram pela porta dos fundos à sala do trono. Os garçons desviam sua função, ao servirem sanduíches aos jornalistas. Como relatou o jornalista, "deram o popular jeitinho".

Para o "jeitinho" ser instituído, neste caso, somou-se uma nova competência e consequentemente performance àquelas para as quais o bufê foi contratado. $O$ "jeitinho" é, então, uma subversão do contrato inicial entre a Casa Real e bufê.

Destaco que, o que ocorre neste caso, a ruptura ou a subversão, já foi detectado em outros estudos de caso apresentados.

Retomando a análise do trecho, o olhar que lanço aqui é no sentido de verificar que tipo de relação se estabelece entre as pessoas que estão a serviço, os garçons e os jornalistas. Em que ambiente estes se encontram (interior ou exterior, protegidos da temperatura?), trabalhando em horário de almoço, com personagens que não têm preocupação ou compromisso com o tempo. Quantas horas haviam se passado? A ordem para servi-los pode ter sido interna. Porém, como foi descrito, parece que foi iniciativa dos garçons, a propósito, não brasileiros, mas caboverdianos. E lhes foram servidos sanduíches, 'para dar uma enganadinha na fome'. Nesse contexto, o 'contrabandear', se no sentido de "ato irregular ou praticado às escondidas" (Houaiss), utilizado pelo autor para designar o ato dos garçons, não seria de todo impróprio. Teria sido o caso de os organizadores terem pensado nos profissionais envolvidos na cobertura do evento e providenciar alguma assistência?

O que motivou a ação dos garçons foi uma preocupação com pessoas, a serviço, provavelmente em situação adversa, e o sentimento despertado foi de atenção "sensibilizada", que gerou um ato de solidariedade.

A compreensão do "jeitinho" como forma de solidariedade está presente na leitura que Pereira Júnior lhe dá, quando escreve que o "jeitinho deve envolver solidariedade, compreensão do falível e valorização da flexibilidade como fator 
criativo" (Pereira Junior, 2013).O "jeitinho" entendido como "sympathy" ${ }^{109}$ foi definido por Rodrigues et al. (2011) como "comportamento de interação social de maneira simpática, agradável e afável, mostrando interesse, afinidade e atração em relação à outras pessoas quando usam o jeitinho" (tradução nossa), portanto, como próximo da solidariedade, no caso, a solidariedade de tentar compreender e de alguma forma aliviar a tensão resultante da dificuldade em solucionar problemas do nosso dia a dia.

DaMatta, no prefácio do livro de Barbosa (2006), descreve como a autora encara o "jeitinho" dentro do contexto da solidariedade:

... um procedimento estrutural, obrigatório (e inevitável) quando se trata de
articular o mais forte com o mais fraco, a carência de quem não tem o
eventual poder de quem tem; e, muito especialmente, a regra geral abstrata,
universal e impessoal, com a compreensão humana, calorosa e solidária
que nasce das relações pessoais, contextualizadas e particulares
(BARBOSA, 2006, prefácio, p. xxi).

A definição de solidariedade no Houaiss, em duas de suas acepções, vem a corroborar com as leituras anteriores: sentimento de simpatia ou piedade pelos que sofrem; manifestação desse sentimento, com o intuito de confortar ou ajudar.

Cito Comte-Sponville (1995), não obstante a complexidade que o autor sugere em relação à solidariedade ("é demasiado interessada ou demasiado ilusória", p. 99), ainda que considerasse que esta deveria figurar em seu Pequeno Tratado das Grandes Virtudes, porém a ele pareceu que a justiça e a generosidade a substituíram com vantagem: "O que é a solidariedade? É um estado de fato antes de ser um dever; depois é um estado de alma (que sentimos ou não), antes de ser uma virtude ou um valor" (COMTE-SPONVILLE, 1995, p. 98). Talvez, no caso sob análise, a palavra seja simpatia. "O que é simpatia? É a participação afetiva dos sentimentos do outro (ter simpatia é sentir juntos, ou do mesmo modo, ou um pelo outro), assim como o prazer e a sedução que dela resultam (p.116).

Solidariedade ou simpatia, o importante aqui é o sentimento compartilhado e a ação no sentido de solucionar o problema que a outro aflige.

109 "sympathy" was defined as the behavior of interacting socially in a friendly, pleasant and affable way, showing interest, affinity and attraction towards other people when using jeitinho (Rodrigues et al., 2011). 
Pode-se dizer que o texto analisado tem a compreensão do "jeitinho" mais próxima da solidariedade, e colocada no continuum sugerido por Barbosa (2006), estaria ladeada do favor, na extremidade de leitura positiva do vocábulo.

\subsection{Afinal, como se diz "jeitinho brasileiro" em inglês?}

Como vimos no caso apresentado anteriormente, sobre a leitura do "jeitinho" por estrangeiros, existem algumas possibilidades de entendimento do vocábulo em inglês, a partir de sinonímia ou expressões.

Além delas, durante a leitura da bibliografia necessária para a confecção da minha pesquisa, outras sugestões ocorreram. Assim, eu as apresento, retomando brevemente as que surgiram anteriormente e, em seguida, contemplo as que aparecem como primeiro registro na pesquisa. Ao final da apresentação das possibilidades, analiso cada termo ou expressão, tendo por objeto o registro de ocorrências, fazendo uso da Linguística de Corpus ${ }^{110}$ (LC) e o Contemporary Corpus of American English (COCA). Utilizo a LC tendo por objetivo buscar a correspondência mais fidedigna possível, inclusive com números de ocorrências, e com o intuito de mostrar que a dificuldade do entendimento do jeitinho se transfere para a tradução.

Inicio fazendo referência à forma como o primeiro-ministro holandês, Jan Peter Balkenende, que nomeou o "jeitinho" como "ability", em caso relatado pelo jornalista Clóvis Rossi.

Borges (2005), no abstract, em inglês, de sua tese de doutorado, pontua que "jeitinho brasileiro poderia ter sido traduzido por 'Brazilian way'. A escolha por não traduzir jeitinho brasileiro se deve ao fato de que jeitinho inclui a conotação de habilidade, que seria perdida se fosse traduzido" (BORGES, 2005, p. 7, tradução minha).

Ainda no estudo do mesmo caso, a jornalista Samantha Pearson, no blog Beyond Brics, do jornal britânico Financial Times, o chama de "little way".

\footnotetext{
${ }^{110}$ LC: uma área que trata do uso de corpora computadorizados (coletâneas de textos, escritos ou transcrições de fala, mantidas em arquivo de computador). Ao revelar uma quantidade surpreendente de evidências linguísticas provindas de corpora eletrônicos, a Linguística de Corpus questiona os paradigmas estabelecidos dos estudos linguísticos e mostra novos caminhos para o linguista, o professor, o tradutor, o lexicógrafo e muitos outros profissionais (BERBER SARDINHA, 2004, prefácio, p. xvii).
} 
Rosenn (1971), em sua abordagem voltada ao Direito e às leis, considera-o intraduzível, e que, grosso modo, corresponderia a "knack", "twist", "way" ou "fix", em inglês.

Em registros outros que não haviam surgido no estudo dos casos, porém, de extrema importância, por se tratar de um especialista no tema do "jeitinho", encontramos DaMatta (1991), que em versão para o inglês de seu Carnavais, Malandros e Heróis, apresenta o "jeitinho" como "clever dodge". Eis um dos trechos em que há a referência: "It is in the space between these two obviously opposite poles that social systems like ours make room for the clever dodge (jeitinho) and roguery"111 (DAMATTA, tradução John Drury,1991, p.235).

Outra estudiosa do tema, Barbosa (1995), em capítulo do livro The Brazilian Puzzle: Culture on the Borderlands of the Western World, prefere utilizar os termos em português, tanto o jeitinho quanto o jeitinho brasileiro. Apresenta a pronúncia, jay-tchee'-nyoo, e assim se refere a eles: "The jeitinho is predominantly linked to a specific way of asking for things in the context of a social drama, and jeitinho brasileiro always refers to a way of defining Brazil as a nation and Brazilians as a people $^{112 "}$ (BARBOSA, 1995, p. 36).

A autora alerta para o fato de que não há uma tradução precisa dessa expressão. Eis sua definição: "It can be defined, in a very broad sense, as a fast, efficient, and last-minute way of accomplishing a goal by breaking a universalistic rule and using instead one's informal social or personal resources ${ }^{113}$ " (BARBOSA, op. cit. p. 36).

Para a autora, não é possível traduzir "dar um jeitinho". Em sua busca por uma correspondência, o registro mais próximo seria "to pull a string" e "to cut through the red tape". No entanto, salienta que nenhuma das expressões implica em quebrar regras ou usar de relações pessoais.

\footnotetext{
${ }^{111}$ É no espaço formado entre esses dois polos francamente contrários que os sistemas como o nosso engendram o campo social do jeitinho e da malandragem (DaMatta, 1983, p.231).

${ }^{112} \mathrm{O}$ jeitinho está ligado predominantemente à forma específica de pedir algo no contexto de um drama social e o jeitinho brasileiro se refere sempre à maneira de definir o Brasil como nação e os brasileiros como povo (tradução nossa).

${ }^{113}$ Ele pode ser definido, em um amplo sentido, como uma forma rápida, eficiente e de última hora de atingir um objetivo, quebrando uma regra universal, usando suas relações pessoais e informais (tradução nossa).
} 
Entre os pesquisadores brasileiros radicados no exterior encontramos Augusto Zimmermann, palestrante e professor na área de Direito, da Murdoch University Law School, Western Australia. Zimmermann (2012) também traduz o "jeitinho" como "knack" ou "clever dodge". Sua análise do mecanismo é bem próxima à de Rosenn, pois ambos consideram o "jeito" como "institutional bypass of law", ou seja, "um desvio institucional da lei".

Como representante da mídia impressa americana, registro Roger Cohen, colunista do jornal The New York Times, que, escrevendo na coluna opinião do editor (op-ed), publicada em 03 de janeiro de 2008, discorre sobre as lições do Brasil para o ano que estava começando. Comenta que o Brasil é diferente. Ressalta que, à época, o país encontrava-se em franca expansão de mercado, com excelentes níveis de crescimento das indústrias de petróleo e etanol, exportando aviões, enfim, um cenário bastante estimulante. Dentro desse contexto animador, ainda há o "jeitinho" - "ingenuous fix" - para qualquer eventualidade.

Registro, ainda, as sugestões feitas por Michael A. Jacobs. Nascido em Londres e radicado no Brasil desde 1967, professor de inglês, tradutor, autor de livros, apresenta algumas opções para a expressão: "work something out"; "have to"; "help (someone) out"; "get out of"; "find a way round".

Existe também a solução de traduzi-lo como "Brazilian way", que aparece como uma opção espontânea.

A seguir, analiso os vocábulos em inglês, a partir das definições em dicionários, sinônimos, sugestões de uso, e aqui, utilizo, inclusive, os dicionários informais, buscando as possíveis ocorrências e, o que é, de fato, passível de entendimento como "jeitinho". Como já foi dito, em busca de fidedignidade máxima dos dados, faço uso da Linguística de Corpus, com levantamento de dados referentes ao termo, através de consultas ao $C O C A^{114}$ (Corpus of Contemporary American English), ferramenta que fornece o número de ocorrências e suas fontes. Primeiramente apresento o vocábulo "Ability".

${ }^{114}$ COCA: The Corpus of Contemporary American English, criado por Mark Davies da Brigham Young University. É o maior corpus de língua inglesa gratuito. Dispõe de um banco de mais de 450 milhões de palavras, e compreende o período de 1990-2012. Disponível em: <http://corpus.byu.edu/coca/>. 


\subsubsection{Ability}

No levantamento inicial, o vocábulo aparece com 51.661 registros. Com o objetivo de filtrar dados, busquei o que poderia ser 'colocado'115 com "ability", por exemplo: "Brazilian ability"- sem ocorrência; "people ability"- sem ocorrência; (nem "people's ability"); para "ability of people"- 73. Como colocação para "ability of people", ocorrem: to do something; to see; to enjoy; to express; to design; to change, entre outros, mas nenhum registro significativo para o entendimento de "ability" como "jeitinho".

No dicionário, tem-se:

1. Possession of the means or skill to do something. // 2. Talent, skill, or proficiency in a particular área ${ }^{116}$ (Oxford Dictionary).

3. Possession of the qualities required to do something; necessary skill, competence, or power ${ }^{117}$ (Collins English Dictionary).

Sinônimos (seleção): capacity, capability, talent, skill, expertise, competence, aptitude, aptness, accomplishment, potential, power ${ }^{118}$ (Oxford Dictionary).

"Ability" teria como correspondentes em português, habilidade, capacidade, talento, aptidão, destreza, competência, ter o poder de, ter o potencial de, ser capaz de. Pode, portanto, ser considerado um requisito para o "jeitinho", mas se confundiria com ele, isoladamente, não teria o mesmo valor. Para conseguir o "jeitinho", o sujeito precisa de ter habilidade juntamente com outros quesitos.

\subsubsection{Little way}

A sugestão apresentada pela jornalista Pearson, do Beyond Brics, do FT, seria uma tradução literal de "jeitinho", ou "pequeno jeito". Esta é a forma que prevalece nos registros que realizei da mídia impressa inglesa. Além da ocorrência

115 “[...] unidades (linguísticas) são, em geral, formadas por uma base e um colocado. A base é a palavra que conhecemos, a que carrega mais conteúdo semântico, a que determina a ocorrência da outra, pois há uma hierarquia entre os elementos. O colocado é a palavra que não conhecemos ou que não nos ocorre; é aquela que é determinada pela base e que precisamos aprender em conjunto com ela" (TAGNIN, 2005, p. 30).

116 (1 e 2) Disponível em: <http://www.oxforddictionaries.com/definition/english/ability?q=ability>. Acesso em: 11 mar. 2014

117 (3) Disponível em: <http://dictionary.reference.com/browse/ability?s=t>. Acesso em: 11 mar. 2014. 118 Disponível em: <http://www.oxforddictionaries.com/definition/english-thesaurus/ability?q=ability>. Acesso em: 11 mar. 2014. 
no $F T$, quatro artigos foram extraídos do site da $B B C N e w s^{119}$, em que abordam o "jeitinho brasileiro". Além de utilizarem a expressão em português, surgem também o "jeito" e o "jeitinho", e na tradução utilizam "little way" (duas vezes) e "Brazilian way" (também duas vezes). Quanto a seus usos, reforçam o sentido de "quebrar regras e ignorar a lei".

Em consulta ao COCA, "way" aparece com 473.745 registros. Colocado com little, "little way" surge em 265 ocorrências. A compreensão que predomina nos trechos citados é em relação à caminho, rota, trilha. Em nenhum caso pude observar qualquer referência ao "jeitinho" ou algo relativo ao Brasil ou brasileiros.

\subsubsection{Knack}

O número de ocorrências no COCA foi de 1.299. Com a colocação Brazilian, não houve nenhum registro. Utilizando a ferramenta de tradução $L_{i n g u e e^{120}}$ foi possível localizar pelo menos uma ocorrência em que "jeitinho brasileiro" foi traduzido como "Brazilian knack". A tendência foi para o entendimento como habilidade, talento, dom, e até jeito, no sentido de maneira, forma.

Eis as ocorrências em dicionários:

1. A clever, expediente way of doing something (The American Heritage Dictionary of the English Language).

2. A skilful, ingenious, or resourceful way of doing something. // 3. A particular talent or aptitude, esp. an intuitive one ${ }^{121}$ (Collins English Dictionary).

Sinônimos: gift, talent, ability, capability, aptitude, aptness, adroitness, trick, competence, expertise, proficiency, method, technique, and so on ${ }^{122}$ (Oxford Dictionary).

Pelo que podemos observar e constatar, "ability" e "knack" apresentam alguns sinônimos em comum. Porém, sabemos que a sinonímia completa praticamente

\footnotetext{
${ }^{119}$ Disponíveis em: <http://www.bbc.com/news/world-latin-america-19160439?print=true>. <http://news.bbc.co.uk/go/pr/fr/-/2/hi//business/4468042.stm>. <http://news.bbc.co.uk/go/pr/fr//2/hi/americas/6734407.stm>.<http://www.bbc.co.uk/news/world-latin-america-12554432>. Acesso em: 22 mar. 2014.

${ }_{120}$ Disponível em: <http://www.linguee.com.br/portugues-ingles/page/about.php>. Acesso em: 11 mar. 2014.

121 Disponível em: <http://http://www.thefreedictionary.com/knack>. Acesso em: 11 mar. 2014.

122 Disponível em: http://www.oxforddictionaries.com/definition/english-thesaurus/knack?q=knack. Acesso em: 13 mar. 2014.
} 
inexiste e dois vocábulos remetem exatamente ao mesmo uso e valor apenas em casos excepcionais.

"Knack" surge com acepção mais ampla que "ability" e, além dos correspondentes em comum no português, somam-se esperteza, astúcia, trapaça, manha, truque, que o tornam mais próximo do "jeitinho".

\subsubsection{Twist}

O número de ocorrências com o vocábulo "twist" no COCA foi de 6.875 . Porém, não havia uma colocação para associar com "twist". Assim, não foi possível a localização de algum termo que o associasse ao "jeitinho". Na ferramenta de tradução Linguee, não há nenhum exemplo que mostre sequer um conteúdo aproximado.

Em relação ao seu significado dicionarizável, temos:

1. To change or cause to change for the worse in character, meaning, etc; pervert.

2. decisive change of direction, aim, meaning or character.

3. a strange personal characteristic, esp. a bad one ${ }^{123}$ (Collins English Dictionary: 1 e 2).

4. a deviation in direction; curve; bend; turn (Oxford Dictionary).

Sinônimos: change, alter, distort, imperfection, defect, deviation, peculiarity ${ }^{124}$ (Oxford Dictionary).

"Twist" apresenta um sentido relativo à mudança: uma alteração, uma distorção ou imperfeição, assemelhando-se a algo relativo ao caráter, pelo menos no que concerne ao "jeitinho".

\subsubsection{Fix}

Em levantamento feito através do COCA, "fix" aparece 14.901 vezes. No dicionário, tem-se:

1. (informal) A dishonest or underhand arrangement ${ }^{125}$ (Oxford Dictionary).

\footnotetext{
123 Disponível em: <http://dictionary.reference.com/browse/twist?s=t>. Acesso em: 13 mar. 2014.

124 Disponível em: <http://www.oxforddictionaries.com/definition/english-thesaurus/twist?q=twist>. Acesso em: 13 mar. 2014.
} 
2. (informal) (esp. passive): to influence the result of something or a person's actions by unfair or illegal means (Oxford Advanced Learner's Dictionary).

Sinônimos: rig, arrange fraudulently, prearrange/predetermine the result of, manipulate, manoeuvre, twist, influence ${ }^{126}$ (Oxford Dictionary).

Quanto ao sentido, "fix" remete a algo manipulado, feito às escuras, de forma desonesta, fraudulenta. Como algumas das acepções referem-se à lei (por exemplo, a sugerida por Rosenn), tal interpretação estaria entre as possíveis para o "jeitinho", em sua aproximação à corrupção.

\subsubsection{Ingenious fix}

Em consulta ao COCA, não há registro da colocação "ingenious fix". Localizei o uso da expressão, utilizando o buscador do Google Battle. Isso me permitiu verificar que, quando a expressão surge, algumas vezes sob a forma "ingenious way to fix", geralmente está associada à soluções mirabolantes, de improviso, para os problemas do dia a dia. Em português, essa ação é denominada "gambiarra". Pode também ser interpretada como soluções engenhosas. É a forma de "jeitinho" associada à criatividade. Porém, há dois registros em que a expressão "ingenious fix" é utilizada e creio que valha a pena sua apresentação e discussão.

Em uma das ocorrências, Roger Cohen, articulista do jornal norte-americano, The New York Times, faz referência direta e expressa ao "jeitinho" (brasileiro) ${ }^{127}$. 0 jornalista o apresenta como uma forma de superar problemas de toda e qualquer ordem. Cohen utiliza um tom em seu artigo que seria um misto de ironia e idílio, como se o "jeitinho", num passe de mágica, resolvesse todos os problemas que afligem uma pessoa. O autor menciona que adotaria o "karma brasileiro", que permite a adoção do "jeitinho brasileiro" para, por exemplo, esquecer todas as pequenas coisas irritantes que povoam a vida dos americanos ${ }^{128}$, como croissants

Disponível em: <http://www.oxforddictionaries.com/definition/english/fix?q=fix>. Acesso em: 15 mar. 2014.

${ }^{126}$ Disponível em: <http://www.oxforddictionaries.com/definition/english-thesaurus/fix?q=fix>. Acesso em: 15 mar. 2014.

${ }_{127}$ Disponível em: <http://www.nytimes.com/2008/01/03/opinion/03cohen.html?_r=0>. Acesso em: 22 dez. 2013.

${ }^{128}$ So l've resolved to adopt Brazilian karma for 2008 and forget all the little irritants that plagues American lives: microwaved croissants, high-five contagion, globalized brunch, death by PowerPoint, shops calling themselves "shoppes", the inconsistency of belt-and shoe-removal rules at airports, 
de micro-ondas, por exemplo. Pelo teor do que escreve, o autor parece que precisa apenas relaxar um pouco, superar o estresse, pois os itens para os quais clama por solução não seriam passíveis de "jeitinho". São devaneios pelos quais o autor se deixou levar.

Outro registro foi identificado na manchete ${ }^{129}$ de um jornal local, da cidade de Reno, no estado americano de Nevada: Ingenious fix to get workers back. A notícia é sobre manobra que foi realizada pelo Congresso americano, the House, após a paralisação das atividades de funcionários de órgãos federais dos Estados Unidos, em outubro de 2013, decorrente do impasse sobre a lei orçamentária americana. A manchete insinua que acordos excusos e manobras ocorreram no Congresso para se conseguir fazer com que os trabalhadores voltassem ao trabalho, e que a mesma coisa deveria acontecer no Senado, seguindo o voto dado no sentido de pagar os dias parados. Há forte indicação na reportagem de que se discutiram formas de dar um jeito de acabar com a paralisação. Se assim os fatos ocorreram, há indícios de que tenham "dado um jeitinho".

\subsubsection{Way}

Assim como o vocábulo "jeito" em português, "way" tem grande ocorrência, 473.745. Por isso, é muito amplo seu campo semântico e sua gama de ocorrências. Utilizado para falar da maneira ou da forma como as coisas acontecem, para direcionar a busca, recorri aos colocados de que se tem algum registro. "Little way", que já foi apresentado anteriormente e, Brazilian, resultando na expressão "Brazilian way", que no COCA conta com 4 ocorrências.

\subsubsection{Brazilian Way}

Provavelmente por ser a forma traduzida mais espontânea que remete ao "jeitinho", foi também a que apresentou o maior número de ocorrências no COCA (4), em relação aos registros coletados. Também foi a forma utilizada em algumas reportagens da $B B C$ News (já mencionadas anteriormente).

Apple addicts vaunting the latest gadgets and people who convey agitation or anger by writing in ALL CAPS (Cohen, 2008). Disponível em:

<http://www.nytimes.com/2008/01/03/opinion/03cohen.html?_r=0>. Acesso em: 22 dez. 2013.

${ }_{129}$ Disponível em: <http://www.rgj.com/article/20131010/OPED02/310100013/Ingenious-fix-getworkers-back?nclick_check=1>. Acesso em: 31 jan. 2014. 
Uma das ocorrências foi publicada em artigo na revista National Geographic Traveler, de abril de 2011, tendo Dalsann McLane como autor, sob o título Our Favorite Hotels in South America. Eis o trecho: "Aren't they beautiful?' 'Tiacho half sings, half sighs' 'It's the Brazilian way, you know - you paint something in bright colors, and it makes you feel so much better!". Tiacho é um artista instalado em Parati, RJ, referindo-se ao seu trabalho de pintura realizado em barcos de pesca da região.

Em outro registro, no periódico acadêmico Anthropological Quarterly, de julho de 1998, sob o título: Ethnicity and the Anthropologist: Negotiating Identities in the field, a expressão ocorre desta forma: "Instead, it had been a Brazilian sense of informality and a willingness to bend rules - the jeitinho brasileiro (the Brazilian way of doing things) - that had finally landed me a factory job." Aqui a ocorrência aparece com o significado que usualmente é dado ao "jeitinho brasileiro", como mecanismo de navegação social, em que há certo nível de informalidade e disposição em desrespeitar normas e regras.

A terceira ocorrência teve como fonte a Consumers Research Magazine, de novembro de 1991, sob o título: Can herbal teas be toxic?, de autoria de S. Snider.: 'Other companies also make questionable claims. One markets a 'dieter's tea' as a 'lowcal food'. Another markets a tea described as 'the Brazilian way of losing weight without suffering"'. Refere-se a propagandas que são questionadas por anunciarem chá dietético como alimento de baixa caloria, dentre as quais um anúncio de chá descrito como sendo a forma de os brasileiros perderem peso sem sofrer.

O quarto registro é o de artigo publicado na revista Forbes, de julho de 1990, de autoria de C. Poole e W. Heuslein, sob o título The Americas, sendo essa a reportagem da capa da edição: "In Ermirio's case, he was reportedly caught with $\$ 500$ million playing the overnight money market - a Brazilian way to keep up with hyperinflation - when his funds were frozen". $O$ trecho faz referência a um recurso financeiro ao qual o empresário Antônio Ermírio de Moraes, presidente do Grupo Votorantim, recorreu para fazer frente à inflação, que seria a aplicação no mercado financeiro de 500 milhões de dólares, por uma noite, quando seu capital estava congelado. Aborda o "jeitinho" por um ângulo similar ao da jornalista S. Pearson, do blog Beyond Brics. 
Entre as quatro sugestões de Brazilian way, a primeira referência aborda 0 assunto em relação às artes e arquitetura, a forma como o artista brasileiro, segundo o autor, gosta de trabalhar com as cores. A terceira menciona um chá ou alimento dietético, ao qual os brasileiros, também segundo seu autor, recorrem para perder peso sem sofrer. Esses dois registros não se assemelham à forma de "jeitinho" detectadas na segunda e a quarta ocorrências. A primeira faz uso da expressão de forma similar à quarta, pois referem-se ao "jeitinho" como forma de driblar regras e convenções.

\subsubsection{Clever Dodge}

A expressão "clever dodge" foi utilizada como correspondente ao termo "jeitinho" no livro de Roberto DaMatta, Carnival, Rogues and Heroes, de 1991, traduzido por John Drury. Vejamos no dicionário, como o vocábulo é definido:

- A cunning trick or dishonest act, in particular one intended to avoid something unpleasant ${ }^{130}$ (Oxford Dictionary).

O significado remete a um truque ou ato desonesto com a intenção de evitar algo desagradável.

Sinônimos: scheme, tactic, stratagem, subterfuge, trick, treat, deception, pretext, manouvre, scam ${ }^{131}$ (Oxford Dictionary).

No COCA, conta com apenas um registro para a expressão. A ocorrência se deu em 20 de abril de 1998, no programa Good Morning America (GMA), da rede de televisão americana, $A B C$, sob o título, Legacy of Linda McCartney. O âncora do programa, Anthony De Curtis comenta (sobre o casal): "Absolutely. And they had a real family. They had a real relationship. You know, the joke among rock stars is always, you know, 'So who did you write that song about?' And, it's, 'Well, darling, they're all about you.' And, like, while that's usually a clever dodge, in Paul's case, it was true. All of his love songs were about Linda.

"Clever dodge", no trecho, assemelha-se a um estratagema, uma tática que os astros de rock usam para conquistar garotas. A conotação atribuída à expressão

\footnotetext{
${ }^{130}$ Disponível em: <http://www.oxforddictionaries.com/definition/english/dodge?q=dodge >. Acesso em: 28 jan. 2014.

${ }^{131}$ Disponível em: <http://www.oxforddictionaries.com/definition/english-thesaurus/dodge?q=dodge>. Acesso em: 28 jan. 2014.
} 
mostra-se próxima ao "jeitinho", quando visto como algo desonesto, em sua perspectiva negativa, como uma mentira para tirar proveito da situação.

\subsubsection{Pull String}

Sugestão feita por Barbosa (1995), com a ressalva de ser uma das expressões idiomáticas com significado mais próximo do "jeitinho" que a autora pode encontrar, "pull (a/the) string", apresenta como definição:

- To secretly use the influence that you have over important people in order to get something to help someone (Cambridge Idioms Dictionary).

- To use influence (with someone to get something done) (McGraw-Hill Dictionary of American idioms and Phrasal Verbs).

Analisando o uso da expressão em um exemplo, seu sentido torna-se mais claro e passível de melhor compreensão: "I may be able to pull a few strings for you if you need the documents urgently"132. A expressão se assemelha muito com o nosso "mexer os pauzinhos", que seria um "jeitinho", ao se pedir um favor para superar alguns entraves burocráticos, por exemplo.

No levantamento realizado no COCA, "string" aparece 10.080 vezes. Colocado com "pull (a/the/my/her/some/every/off/few/your/-)", as ocorrências diminuem para 52. Alguns desses registros apresentam uma significação próxima àquela mostrada no exemplo. No entanto, uma referência chamou a atenção pelo fato de se tratar de assunto político, envolvendo a União Europeia, em um evento que teve lugar na cidade de Bruxelas, em 08 de maio de 2008. Durante os debates no parlamento europeu, em sessão que se discutia a delimitação das atividades dos lobistas nas instituições da União Europeia, representante da opinião do Comitê do Meio Ambiente, da Saúde Pública e da Segurança Alimentar, Claude Turmes, utiliza, em seu discurso, duas vezes a expressão "pull the strings". Na primeira ocorrência, pede por mais transparência, pois sem isso não poderia existir uma Europa Democrática, e que Bruxelas já tem a reputação de permitir que as grandes

132 Disponível em: <http://idioms.thefreedictionary.com/pull+strings>. Acesso em: 11 mar. 2014. 
corporações tomem as decisões e realizem manobras ${ }^{133}$ ("deem as cartas" e "mexam os pauzinhos").

Não seria essa uma das situações que, se fosse notícia sobre atuação de grupos de influência no Congresso Nacional ou alguma outra situação no Brasil, teria dado margem à interpretação como uma forma de "jeitinho"?

\subsubsection{Cut through red tape}

Outra expressão sugerida por Barbosa, como uma vaga correspondência ao "jeitinho" é "cut through red tape". A definição para a expressão idiomática é a seguinte:

- To eliminate or neutralize something complicated, such as bureaucratic rules and procedures (McGraw-Hill Dictionary of American Idioms and Phrasal Verbs).

Similar ao "quebrar regras", tal definição se assemelha com o "jeitinho" como "mecanismo de navegação social, do qual se faz uso para burlar regras e solucionar algum problema ou situação difícil". Quando se observa um exemplo, a assunção fica mais perceptível: "I will try to cut through all the red tape for you so you get your visa on time" 134 .

Em relação ao número de ocorrências no $C O C A$, para "cut through", tem-se 1.555. "Red tape" apresenta 802. Para "through red", 155, e para a expressão idiomática "cut through the red tape, 15 registros. Um deles, uma reportagem do The Denver Post, publicada em 25 de dezembro de 2005, de autoria de Greg Griffin, sob

\footnotetext{
${ }^{133}$ Claude Turmes, draftsman of the opinion of the Committee on the Environment, Public Health and Food Safety. - (DE) Mr President, without transparency, there can be no European democracy. Brussels already has a reputation for allowing the major corporations to call the shots and pull the strings. That is dangerous for the European project, and it is an issue which is of great concern to me on a personal level and to the Greens as a whole. As the European Parliament, we therefore have a responsibility to show our hand to voters in the run-up to the next European elections. We have a good report in front of us, but there are dark forces at work and they want to suppress two of its core elements. Firstly, they want to prevent financial transparency. Without financial transparency, we can never be sure who is really behind the campaigns. I am astonished to find that it is actually the Socialist Group which is opposed to financial transparency and is thus undermining one of these core elements. As for the second core element which is being undermined, there are people in Parliament who assume that lawyers should not be regarded as lobbyists, even if they are not defending people in court, but instead are trying to pull strings to influence legislation in Europe. Disponível em: $<$ http://www.europarl.europa.eu/sides/getDoc.do?pubRef=-

//EP//TEXT+CRE+20080508+ITEMS+DOC+XML+VO//EN\&amp;language=EN\#creitem3>. Acesso em: 22 mar. 2014.

${ }_{134}$ Disponível em: <http://idioms.thefreedictionary.com/cut+through+red+tape>. Acesso em: 11 mar. 2014.
} 
o título $A$ look at Joe Nacchio ${ }^{135}$, permite-nos notar a semelhança de sentido com o "jeitinho": "He was known for his technical mastery and ability to cut through red tape to complete big jobs quickly" (grifo nosso). A reportagem se refere ao executivo americano da área de comunicações, Joseph P. Nacchio, que presidiu a Qwest Communications International, de 1997 a 2002, e enfrentou vários processos que culminaram com sua prisão em 2009.

Realmente, as duas expressões sugeridas por Barbosa ("to pull a string" e "to cut through (the) red tape") não são traduções precisas para o "jeitinho", mas discordo quando a autora diz: "However, neither expression implies breaking rules or using personal resources" (BARBOSA, 1995, p.36). Creio que os exemplos são bem contundentes em mostrar a semelhança com o mecanismo tupiniquim quando há a quebra de regras.

Será que, a partir disso, eu poderia dizer: “Oh, existe 'jeitinho' em outros lugares, inclusive nos Estados Unidos da América!"?

\subsubsection{Work (sth) out; Have to; Help (sb) out; Get out of; Find a way round}

Por que tais expressões estão compondo um único item? Pelo fato de que eventualmente, dependendo da situação de uso, podem ter o sentido de "achar uma forma de lidar com algo"; "como arranjar uma solução para determinada situação"; "descobrir uma maneira de atuar"; "mostrar habilidade para resolver problemas". Não seriam, necessariamente, as formas utilizadas para falar do "jeitinho", nas quais fiquem evidentes as similaridades com o mecanismo. A sugestão de uso dessas expressões foi dada por Michael Jacobs ${ }^{136}$. O autor responde às dúvidas de leitores, em um blog ${ }^{137}$ criado e mantido também por outros autores de livros de inglês, com explicações simples, de modo a facilitar o entendimento pelo leitor. Jacobs, em sua explicação sobre o "jeitinho", usa diferentes exemplos, procurando expandir as possibilidades. Apresenta, então, cinco expressões, que são as citadas acima. Eis o que ele menciona, a despeito do fato:

\footnotetext{
${ }^{135}$ Disponível em: <http://www.denverpost.com/search/ci_3339508\#ixzz2wz4nJ6IT>. Acesso em: 25 mar. 2014.

${ }_{136}$ Disponível em <http://www.teclasap.com.br/como-se-diz-jeitinho-brasileiro-em-ingles-parte1/>.<http://www.teclasap.com.br/como-dizer-jeitinho-brasileiro-em-ingles-parte-2/>. $<$ http://www.teclasap.com.br/como-dizer-jeitinho-brasileiro-em-ingles-parte-3/>. Acesso em: 02 jun. 2011.

${ }_{137}$ Disponível em: <http://www.teclasap.com.br/blog/>. Acesso em: 02 jun. 2011.
} 
Veja só o que está acontecendo. Não há uma só palavra nem expressão que cubra as eventualidades. Eu poderia criar mais exemplos, mas tenho certeza de que aconteceria a mesma coisa - e ainda corro o risco de entediar você. Pode parecer lugar-comum dizer "cada caso é um caso", mas é isso mesmo. Parece não haver "jeito" de se fugir deste fato. $E$, de quebra, isso também explica por que é difícil traduzir "dar um jeito" (JACOBS, 2009).

A declaração de Jacobs enfatiza a dificuldade, inclusive da tradução, do termo.

\subsubsection{Brazilian jeitinho}

Alguns trabalhos acadêmicos, de pesquisadores brasileiros que atuam em universidades estrangeiras e desenvolvem trabalhos na área de abrangência do "jeitinho brasileiro", mostram uma tendência de escolha em chamá-lo de "Brazilian jeitinho", que seria a forma mais próxima, em termos lexicais, que se poderia ter. Pode também ser um artifício para possibilitar agilidade ao leitor quando pesquisa o tema. Enfim, creio que seja uma escolha bastante pertinente, pois eliminaria o uso de tantas expressões, que seriam utilizadas para dar o devido esclarecimento de que tipo de "jeitinho" o autor estaria se referindo. Cito dois exemplos: Brazilian jeitinho: Understanding and explaining an indigenous psychological construct, artigo publicado em Interamerican Journal of Psychology, em 2011, vol. 45, Num. 1, pp. 29-38, de autoria conjunta de pesquisadores da Universidade de Brasília, Rodrigues, R. P. e Porto, J. B.; da Universidade Salgado de Oliveira, Ferreira, M. C.; e da Victoria University of Wellington, Nova Zelandia, Milfont, T. L. e Fischer, R.; e Exploring the Interpersonal Transaction of the Brazilian 'Jeitinho' in Bureaucratic Contexts, de autoria de Duarte F., pesquisadora da University of Western Sydney, Australia, publicado em Organization, vol.13(4): 509-527, 2006.

É certo que essas opções para a tradução do termo "jeitinho" não são as únicas. No entanto, a minha tarefa foi a de dar voz e vez às formas mais utilizadas, que persistiram durante a realização da pesquisa, ou que de certa forma, compreenderam a gama de sentidos de forma clara, que tornasse possível a identificação do "jeitinho" na leitura. Tive a intenção de abranger as várias formas que compõem o que tem sido chamado de continuum, em suas diversas nuances. 
Esta dissertação teve como objetivo principal o estudo da amplitude do campo semântico que o vocábulo "jeitinho" e seus parassinônimos apresentam. A partir das diferentes possibilidades de seu uso, sugeridas pelas definições, aferidas em dicionários e apresentadas por escritores e estudiosos, busquei, com a utilização de vários textos de gêneros diversos, os diferentes efeitos de sentido passíveis de se identificarem para a lexia.

A análise desses textos permitiu que eu elencasse algumas possibilidades de leitura para além do favor, passando pelo jeito, até o limite da corrupção, tomando por base o continuum de Barbosa (2006).

Assim, pude interpretar o "jeitinho" de diferentes formas. Isso apenas foi possível como consequência do estudo dos casos que compõem o corpus da pesquisa. A partir da leitura de cada texto, sob a perspectiva da semiótica discursiva francesa, percebi que poderia distinguir e identificar gradações, inclusive nas próprias definições fornecidas por Barbosa, como quando ela diz que a resolução do problema pode ser feito com o uso de conciliação, esperteza ou habilidade. Dessa forma, proponho uma gradação mais detalhada para a gama semântica do "jeitinho brasileiro", a partir da colocação de cada caso estudado em um ponto aproximado entre o "favor" e a "corrupção". Os títulos empregados remetem aos casos estudados, por isso o último se chama "Jeitinho Brasileiro": ele remete à canção do grupo de garotas catarinenses. Reconheço que isso pode gerar estranheza ou até certa confusão, pois "jeitinho brasileiro" assume posição de todo e de parte, porém, como é esse o título da canção analisada, é o ônus a pagar pela fidelidade. 


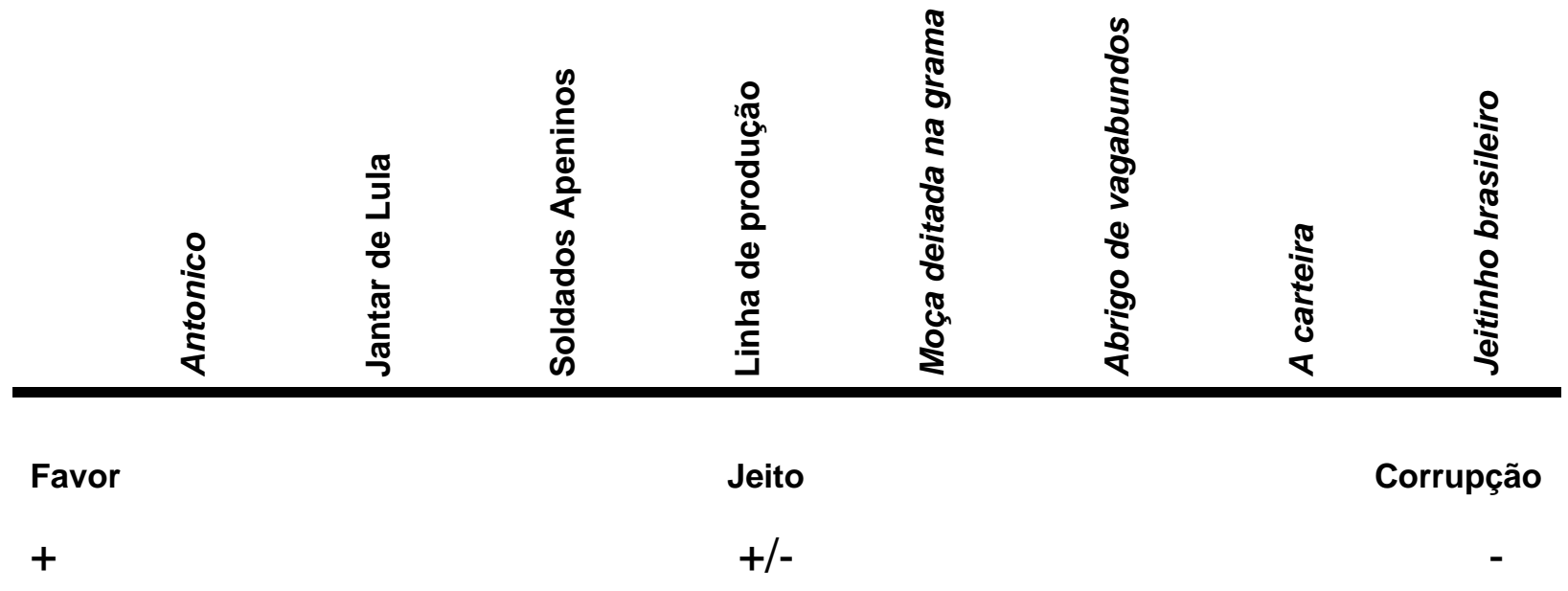

Solidariedade, sobrevivência, habilidade, criatividade, flexibilidade, improvisação, charme, simpatia, malandragem, prevaricação, hipocrisia, flexibilidade moral são as possibilidades presentes nos textos analisados.

Eis as acepções identificadas em cada texto:

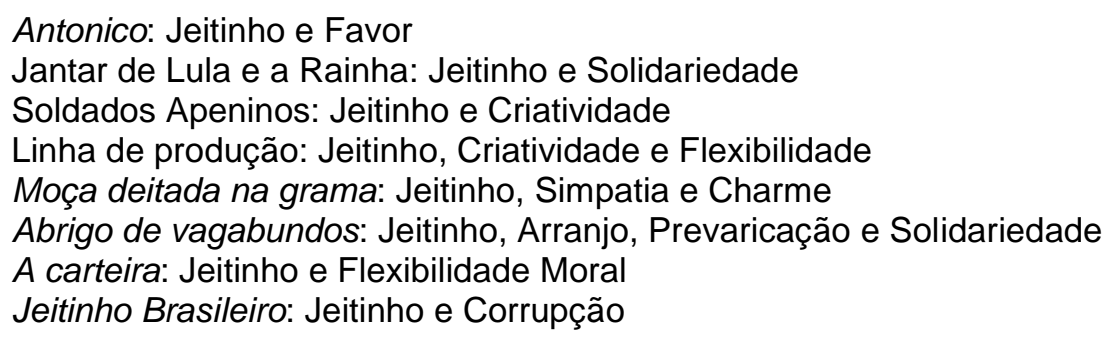

Quando se acrescentam novas características sobre o eixo horizontal, podese nomear uma ação como habilidade, improviso, flexibilidade ou prevaricação, por exemplo. Mas uma pergunta nevrálgica precisa ser enfrentada e uma resposta lhe ser oferecida: o que têm em comum as ocorrências ao longo desse continuum, para merecerem, com maior ou menor concordância, todas elas, o nome de "jeitinho brasileiro"?

Em todas elas, o cidadão cede espaço ao indivíduo, as relações públicas são trazidas para o âmbito privado, tendo como meta a resolução de um problema. A resolução é sempre pontual e pessoal, não se generaliza a outros casos, nem a outros problemas, nem mesmo semelhantes. O jeitinho brasileiro tem múltiplas 
facetas, mas sempre traz à baila resoluções individuais para problemas que podem ser individuais ou sistêmicos.

Bauman (2001), em referência a Tocqueville, afirma

\begin{abstract}
Se o indivíduo é o pior inimigo do cidadão, e se a individualização anuncia problemas para a cidadania e para a política fundada na cidadania, é porque os cuidados e preocupações dos indivíduos enquanto indivíduos enchem o espaço público até o topo, afirmando-se como seus únicos ocupantes legítimos e expulsando tudo mais do discurso público (BAUMAN, 2001, p. 46).
\end{abstract}

Numa sociedade de consumidores, na qual os indivíduos buscam resultados imediatos, em um culto à novidade, que apregoa o desengajamento e que não valoriza a cultura de aprendizagem, em que não se tem e não se valoriza a memória, a educação e o processo de formação da cidadania se ressentem. A formação do cidadão como alguém que exerce direitos, cumpre deveres, numa sociedade em que o individualismo se sobrepõe ao coletivo, em que cada um busca solução para os seus problemas, vivendo, segundo Bauman, numa sociedade líquido-moderna na qual "o indivíduo entra em combate com o cidadão", todo o processo fica comprometido, seja no âmbito da cidadania, seja na educação.

Aliado à questão da educação, o fato das leis serem vistas como desconectadas do nosso cotidiano, e às vezes, realmente são, faz com que o "jeitinho" seja visto como o modo de humanizá-las, e de certa forma escapar do excesso de formalismo na condução da coisa pública.

Em relação ao jeitinho, é sempre o indivíduo que se coloca, nunca o cidadão. Por isso o jeitinho tem tentáculos tão nocivos, mesmo que tenha facetas inocentes - e tem. Por exemplo, se o jeitinho é intersubjetivo (o fiscal da prefeitura foi um grande amigo e arranjou tudo), a pessoa consegue que o fiscal aja como pessoa mais que como funcionário. Havendo ou não propina, ele está destacando a situação daquele que the pede o 'favor' do conjunto de situações semelhantes e the dando um tratamento especial, pessoal.

Tendo desenvolvido o conteúdo acima, só dá para entender como "jeitinho brasileiro" pequenas corrupções, pequenos delitos. Os grandes - um advogado se apoderar de aposentadorias para enriquecer - ficam de fora do jeitinho, pois, embora se trate de trazer o público para o privado, não há dois destinadores (um 
público e um privado, há apenas o privado), e não há tampouco "solução de um problema". Desaparece o conteúdo de solidariedade, de 'ajuda', de 'fechar os olhos para um pequeno desvio'.

Minha intenção não foi nem santificar nem demonizar o "jeitinho". Apenas procurei expor as diversas possibilidades. Porém, proponho que o "jeitinho" não seja tão estigmatizado pelo discurso negativo, pois quando associado a ele, algo como "esse país não tem jeito", é utilizado de maneira simplista, e geralmente carece de uma análise mais acurada. Frequentemente, é acionado quando as pessoas se sentem frustradas e com poucas expectativas. De acordo com Schwarcz, em entrevista concedida à Revista de História,

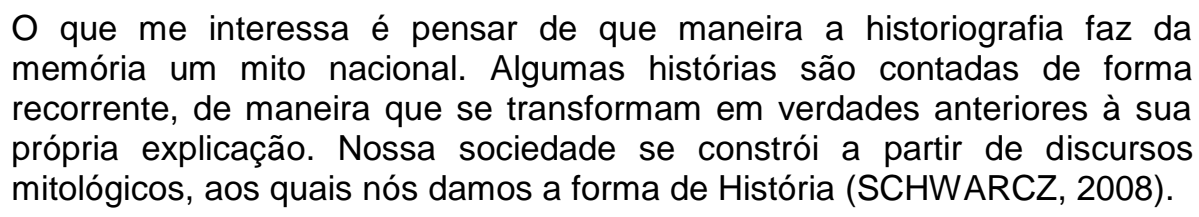

Em relação à tradução do termo "jeitinho", certamente outras possibilidades existem... Duas sugestões apresentadas por Barbosa (2006), pull strings e cut through the red tape merecem um estudo mais acurado, com o intuito de verificar se, de fato, não ocorrem situações que se assemelham ao nosso "jeitinho", pois parece ser possível que em algum momento também passem pela ilegalidade frequentemente associada ao "jeitinho brasileiro".

Finalmente, um estudo mais minucioso poderia ser realizado, pela frequência e elasticidade que o vocábulo "jeitinho" apresenta com a acepção "malandragem". Difícil de valorar, de escapar da moralização, como chamá-los de pequenos golpes ou grandes golpes? Tome-se por exemplo o uso indevido do cartão Bolsa Família, que é um "programa de transferência direta de renda que beneficia famílias em situação de pobreza e de extrema pobreza em todo país" ${ }^{138}$. Circulou em várias mídias um vídeo no qual uma mãe, a senhora Francisca Flores, do estado do Maranhão, beneficiária do programa, reclamava de não conseguir comprar, com o dinheiro da bolsa, uma calça de marca famosa para a filha de 16 anos. Tem-se

\footnotetext{
${ }^{138}$ O Bolsa Família integra o Plano Brasil Sem Miséria, que tem como foco de atuação os milhões de brasileiros com renda familiar per capita inferior a $R \$ 77$ mensais e está baseado na garantia de renda, inclusão produtiva e no acesso aos serviços públicos. Lei 10.836/2004 e regulamentado pelo Decreto no 5.209/2004. Disponível em: <http://www.mds.gov.br/bolsafamilia>. Acesso em: 28 jun. 2014.
} 
acesso ao vídeo em alguns $\operatorname{sites}^{139}$. Na revista Veja, três de seus colunistas se dedicaram ao assunto em seus blogs ${ }^{140}$. Houve também o caso ${ }^{141}$, ocorrido em Itapetinga, a $316 \mathrm{~km}$ de Salvador, de um homem que quis pagar pelo programa de uma prostituta com o cartão Bolsa Família. A moça não aceitou, discutiram, a polícia foi acionada.

Existem relatos sobre o desvio de uso do cartão Minha casa melhor ${ }^{142}$, programa que libera crédito para quem comprou imóvel através do programa da habitação do Governo Federal. Pesquisas ${ }^{143}$ realizadas entre os estabelecimentos credenciados pela Caixa Federal apontam que portadores do cartão poderiam, na prática, comprar produtos que não figuravam na lista, ou produtos cujos valores eram superiores aos fixados pelo governo. Como discutir casos como esses? Existe possibilidade de postá-los no continnum que proponho? O "problema" que busca ser resolvido caracteriza-se de fato como tal? Um desejo (de uma calça de marca ' $x$ ', de um eletrodoméstico ' $y$ ') seria equiparável a um problema como o de Antonico de Adoniran Barbosa?

Responder tal pergunta não é tarefa fácil, nem do escopo deste trabalho. Porém, não nos esqueçamos de que, desde Canclini (2010), sabemos que 'ser cidadão' não significa a mesma coisa em todos os momentos do século XX e, acrescento, XXI. De votante e votável, passou a trabalhador, de trabalhador, chegou a consumidor! Ora, um desejo de consumo, diante de tamanho bombardeamento publicitário nas mídias, não teria, hoje, o valor de uma necessidade? $\mathrm{E}$ uma necessidade a ser satisfeita não se confunde com um problema a ser resolvido?

Sem resposta às indagações levantadas, volto ao tema que elegi.

Entendo que o olhar que lancei sobre o "jeitinho" é um recorte, assim, outros estudos sobre o tema podem ser realizados. Tendo por base o trabalho de Barbosa

\footnotetext{
${ }^{139}$ Disponível em: <http://noticias.bol.uol.com.br/ultimas-noticias/brasil/2013/05/24/entrevista-combeneficiaria-que-quer-comprar-calca-de-r-300-com-o-bolsa-familia-vira-hit.htm>. Acesso em: 13 jul. 2014.

${ }_{140}$ Disponível em: <http://veja.abril.com.br/blog/augusto-nunes/tag/francisca-flores/>; <http://veja.abril.com.br/blog/ricardo-setti/disseram/que-pena-desvalorizacao-do-bolsa-familia-impedeque-beneficiarios-comprem-calcas-de-r-30000/>; <http://veja.abril.com.br/blog/reinaldo/geral/por-queo-numero-de-beneficiarios-do-bolsa-familia-so-cresce/>. Acesso em 13 jul. 2014.

${ }_{141}$ Disponível em: <http://oglobo.globo.com/brasil/homem-tenta-pagar-prostituta-na-bahia-com-cartaodo-bolsa-familia-9057916>. Acesso em 13 jul. 2014.

142 Disponível em: <http://www.minhacasamelhor.com/>. Acesso em: 15 jul. 2014.

${ }^{143}$ Disponível em: <http://veja.abril.com.br/noticia/economia/clientes-e-lojistas-driblam-regras-dominha-casa-melhor . Acesso em: 15 jul. 2014.
} 
(2006), que poderia ser visto como uma "teoria do jeito", meu estudo foi baseado na concretude dos casos, pois foram eles que permitiram as leituras que resultaram na ampliação das características afins do "jeitinho", diminuindo assim, sua elasticidade. Enfim, uma tentativa de "dar um jeito nos jeitos". 
ABENSUR, E. O.; FISCHMANN, A. A.; BRUNSTEIN, I.; HO, L. L. Tendências para o auto atendimento bancário brasileiro: um enfoque estratégico baseado na teoria das filas. Rev. de Administração Mackenzie. Ano 4, no 2, p. 39-59, 2003. Disponível em: <http://editorarevistas.mackenzie.br/index.php/RAM/article/view/41>. Acesso em: 27 mai. 2014.

ALMEIDA, A. C. A cabeça do brasileiro. $3^{\mathrm{a}}$ ed. Rio de Janeiro: Record, 2007.

AMOSSY, Ruth. (Org.). Imagens de si no discurso: a construção do ethos. São Paulo: Contexto, 2008.

ANDRADE, C. D. de; BRAGA, R.; CAMPOS, P. M.; SABINO, F. Para gostar de ler. Vol. 1. Crônicas 1. São Paulo: Ática, 2002.

ANDRADE, C. D. de. Moça deitada na grama. In: Moça deitada na grama. Rio de Janeiro, Record, 1987, p. 09-12.

BARBOSA, L. O jeitinho brasileiro: a arte de ser mais igual do que os outros. - Rio de Janeiro: Elsevier, 2006.

. The Brazilian Jeitinho: an Exercise in National Identity. In: The Brazilian Puzzle: Culture on the Borderland of the Western World. Hess, David J.; DaMatta, Roberto (Edit.). New York: Columbia University Press, 1995, p. 35-48.

BARROS, D. L. P. de. Teoria semiótica do texto. São Paulo, Ática, $4^{a}$ edição, 2005.

. Estudos do discurso. In: José Luiz Fiorin. (Org.). Introdução à linguística II: princípios de análise. 4⿳亠丷a ed. São Paulo: Contexto, 2010, p. 187-219.

BAUMAN, Z. Modernidade líquida. Trad. Plínio Dentzien. - Rio de Janeiro: Zahar, 2001.

. Sobre Educação e Juventude: conversas com Riccardo Mazzeo. Trad. Carlos Alberto Medeiros. - Rio de Janeiro: Zahar, 2013.

BENEVIDES, M. V. de M. Cidadania e democracia. Lua Nova, São Paulo, no 33, Aug. 1994. Disponível em: <http://www.scielo.br/scielo.php?pid=S010264451994000200002\&script=sci_arttext>. Acesso em: 30 mar. 2014.

BERTRAND, D. Caminhos da semiótica literária. Bauru, SP: EDUSC, 2003.

BORGES, F. C. A filosofia do jeito: um modo brasileiro de pensar com o corpo. São Paulo: Summus, 2006. 
O jeito do corpo e o jeitinho brasileiro. Tese de doutorado em Comunicação e Semiótica pela Pontifícia Universidade Católica de São Paulo, 2005.

BOSI, A. História concisa da literatura brasileira. 34르 ed. São Paulo: Cultrix, 1994.

CALDAS AULETE. Dicionário Contemporâneo da língua portuguesa. $8^{\underline{a}}$ ed. Rio de Janeiro: Delta, 1987.

Aulete digital. Lexikon

CALDAS, W. O futebol no país do futebol. Lua Nova, São Paulo, v. 3, n. 2, dez. 1986. Disponível em: <http://www.scielo.br/scielo.php?script=sci_arttext\&pid=S010264451986000300005\&lng=en\&nrm=iso >. Acesso em: 27 mai. 2014.

CAMBRIDGE Idioms Dictionary, Cambridge University Press, 2nd ed., 2006.

CAMBRIDGE Dictionary of American English. Cambridge: Cambrigde University Press, 2000.

CAMPOS, R. de O. A técnica e o riso. Rio de Janeiro. Edições APEC, 1966.

CANCLINI, N.G. Consumidores e cidadãos. Trad. Maurício Santana Dias. $8^{\mathrm{a}}$ ed. Rio de Janeiro: Editora UFRJ, 2010.

CANDIDO, A. Dialética da malandragem (caracterização das Memórias de um sargento de milícias). In: Revista do Instituto de Estudos Brasileiros, ํㅜ 8, p.6789, São Paulo, USP, 1970. no 9, 1972.

A literatura e a formação do homem. In: Revista Ciência e Cultura, v. 24, . Vários escritos. São Paulo: Duas Cidades, 1995.

CARVALHO, J. M. de. Cidadania: Tipos e percursos. Lua Nova. São Paulo, no 18, 1996, p. 337-359. Disponível em:

<http://bibliotecadigital.fgv.br/ojs/index.php/reh/article/viewFile/2029/1168>. Acesso em: 30 mar. 2014.

CARVALHO, J. M. de. Cidadania: Tipos e percursos. Lua Nova. São Paulo, ํo 18, 1996, p. 337-359. Disponível em:

<http://bibliotecadigital.fgv.br/ojs/index.php/reh/article/viewFile/2029/1168>. Acesso em: 30 mar. 2014.

Brasileira, 2010

Cidadania no Brasil: o longo caminho - 13ª ed.- Rio de Janeiro: Civilização

CHAUÍ, M. Filosofia. São Paulo, Ed. Ática, 2000. 
COMETTI, D. Adoniran Barbosa. Almanaque música. Folha de São Paulo.

Disponível em: <http://almanaque.folha.uol.com.br/adoniram.htm\#>. Acesso em: 18 mar 2014.

COMTE-SPONVILLE, A. Pequeno Tratado das Grandes Virtudes. Tradução Eduardo Brandão. São Paulo: Martins Fontes, 1995.

CONTIER, A. D.; FERREIRA, D. S.; TUONO, L.; SERENO, T. M. S. B. Adoniran Barbosa: o narrador de uma época. Cad. De Pós-Graduação em Educ., Arte e Hist. da Cult. - Universidade Presbiteriana Mackenzie - São Paulo, v. 3, no 1, p. 127-134, 2003.

CORTINA, A. O Príncipe de Maquiavel e seus leitores: uma investigação sobre o processo de leitura. São Paulo: Editora UNESP, 2000.

COVRE, M. de L. M. O que é cidadania. - São Paulo: Brasiliense, 2002. - Coleção primeiros passos, $3^{\text {a }}$ ed., $10^{a}$ impressão.

CUNHA, A. G. da. Dicionário etimológico da língua portuguesa. - 4 ed. - Rio de Janeiro: Lexikon, 2010.

CUNHA, L. G. (Coord.). Relatório IPCL Brasil. Índice de Percepção do

Cumprimento da Lei. 4ํTRIMESTRE / 2012 - 1ํTRIMESTRE /2013 - ANO 1.

Direito da FGV, Fundação Getúlio Vargas.

DAMATTA, R. O que é o Brasil? - Rio de Janeiro: Rocco, 2004.

Carnivals, Rogues and Heroes: An interpretation of the Brazilian Dilemma. Translated by John Drury. University of Notre Dame Press, 1991.

. O que faz o brasil, Brasil? - Rio de Janeiro: Rocco, 1986.

. Carnavais, Malandros e Heróis: Para uma sociologia do dilema brasileiro. Rio de Janeiro. Zahar Editores, 1983.

DEMURU, P. Batalha do jeitinho. Ilustríssima, Folha de São Paulo, 25 mai. 2014. Disponível em: <http://www1.folha.uol.com.br/fsp/ilustrissima/167572-batalha-dojeitinho.shtml>. Acesso em: 25 mai. 2014.

DISCINI, N. Intertextualidade e conto maravilhoso. $2^{a}$ ed. São Paulo: Associação Editorial Humanitas, 2004.

. Semiótica: da imanência à transcendência (questões sobre o estilo). Alfa Revista de Linguística. São Paulo, v, 53, n. 2, p. 329-351, 2009.

DUARTE, F. Exploring the Interpersonal Transaction of the Brazilian Jeitinho in Bureaucratic Contents. Organization, vol. 13 n. 4 p. 509-527, 2006b. 
. The Strategic Role of Charm, Simpatia and Jeitinho in Brazilian Society: A Quality Study. Asian Journal of Latin American Studies - 2011, vol. 24, no 3, p. 29-48.

FERNANDES, F.; PEREIRA, J. B. B.; NOGUEIRA, O. A questão racial brasileira vista por três professores. Revista USP, São Paulo, n.68, p.168-179, dezembro/fevereiro 2005-2006.

FERREIRA, A. B. de H. Novo Dicionário Aurélio da Língua Portuguesa. 2009.

FERREIRA, M. C. L. A antiética da vantagem e do jeitinho na terra em que Deus é brasileiro (o funcionamento discursivo do clichê no processo de constituição da brasilidade). In Discurso fundador, E. Orlandi (Org.). 3ํㅡㄹ ed., Campinas, SP: Pontes, 2003.

FIORIN, J. L. Linguagem e ideologia. 8ª edição - São Paulo: Ática, 2007

. O éthos do enunciador. In: Em busca do sentido: estudos discursivos. São Paulo: Contexto, 2008.

Elementos de Análise do discurso. $14^{\mathrm{a}}$ ed., $2^{2}$ reimpressão. São Paulo:

Contexto, 2009.

GOERGEN, P. Educação moral hoje: cenários, perspectivas e perplexidades. Educ. Soc., Campinas, v. 28, no 100, p. 737-762, Oct. 2007. Disponível em:

$<$ http://www.scielo.br/scielo.php?pid=S0101-

73302007000300006\&script=sci_arttext>. Acesso em: 29 abr. 2013.

GREIMAS, A. J.; COURTÉS, J. Dicionário de Semiótica. São Paulo: Contexto, 2008.

HARKOT-DE-LA-TAILLE, E. Ensaio semiótico sobre a vergonha. São Paulo: Humanitas, 1999.

HARKOT-DE-LA-TAILLE, E.; LA TAILLE, Y. Construção ética e moral de si mesmo. In: SOUZA, M. T. C. C. de. (Org.). Os sentidos de construção: o si mesmo e o mundo. São Paulo, 2004, v. 1, p. 69-101.

HOLANDA, S. B. de. Raízes do Brasil. 26aㅗ ed. São Paulo, Companhia das Letras, 1995.

HOUAISS, A.; VILLAR, M. de S.; FRACO, F. M. de M. Dicionário Eletrônico Houaiss da língua portuguesa. Rio de Janeiro: Objetiva, 2009.

HOUAISS, A.; AVERY, C.B. Novo Dicionário Barsa das Línguas Inglesa e

Portuguesa. Vols. 1 e 2. APLLETON-CENTURY-CROFTS, New York, 1969.

IANNI, O. A sociedade global. Rio de Janeiro: Civilização Brasileira, 11aㅡ ed., 2003. 
IRIGARAY, H. A. R.; FREITAS, M. E. de; FILARDI, F. Diáspora brasileira e os trabalhadores retornados do exterior: quando a fantasia encontra a realidade. XXXVII EnANPAD. Rio de Janeiro. Set. 2013.

JACOBS, M. A. Como melhorar ainda mais seu inglês. Rio de Janeiro, Editora Campus/Elsevier, 2003.

KOEHLER, M. A inefetividade dos direitos sociais e a mácula à dignidade da pessoa. Conteúdo Jurídico, Brasília-DF: 12 mar. 2014.

LAJOLO, M.; ZILBERMAN, R. A formação da literatura no Brasil. São Paulo: Ática, 1996.

LEAL, C. M. "Gazeta de Hollanda": o desconhecido versiprosa de Machado de Assis. Revista do livro da Fundação Biblioteca Nacional. Rio de Janeiro, no 44, ano 14, jan. 2002, p. 36.

LIPPMANN, W. Public Opinion. 1922. The Project Gutenberg EBook of Public Opinion, by Walter Lippmann. 2004. Disponível em:

<http://www.gutenberg.org/ebooks/6456>. Acesso em: 5 ago. 2013.

LOPES, I. C.; HERNANDES, N. (Orgs). Semiótica: objetos e práticas. - (1 $1^{\underline{a}}$ ed., $1^{\underline{a}}$ reimpressão). - São Paulo: Contexto, 2009.

LUBART, T. Psicologia da criatividade. Trad. Márcia Conceição Machado Moraes. - Porto Alegre: Artmed, 2007.

MACHADO de ASSIS, J. M. A carteira. Disponível em: $<$ http://www.domíniopublico.gov.br/download/texto/bv000169.pdf $\geq$. Acesso em: 24 jan. 2013.

MARTINS, P. H. A sociologia de Marcel Mauss: Dádiva, simbolismo e associação. Revista Crítica de Ciências Sociais, 73, Dezembro 2005: 45-66.

MCGRAW-HILL Dictionary of American Idioms and Phrasal Verbs. The McGraw-Hill Companies, Inc. 2002.

MERRIAM-WEBSTER. Online Dictionary copyright (C 2014 by Merriam-Webster, Incorporated.

MICHAELIS Moderno Dicionário da Língua Portuguesa. Versão online - 1998-2009. Editora Melhoramentos

MONTE MÓR, W. Eu e o outro: imagens refletidas. Um estudo sobre identidade e alteridade na percepção das culturas. Interfaces, no8, v.8 - Porto Alegre, UFRGS/ABECAN, 2008. 
MUNIZ, L. C. F. A configuração do jeitinho brasileiro em narrativas literárias. Dissertação de Mestrado. UNISC, 2009.

OXFORD Advanced Learner's Dictionary. 5th. ed., Oxford: Oxford University Press, 1995.

PEARSON, S. Brazil's monetary jeitinho. Beyond Brics, Financial Times. London. Jan. 15, 2013.

PEREIRA JUNIOR, L. C. O jeitinho que virou little way. Revista Língua Portuguesa. São Paulo. Ano 8, n. 09, mar. 2013, p.18-21.

PEREIRA, B. M. Entre a moral cristã e as práticas políticas: o maquiavelismo nas teorias da razão de estado portuguesas seiscentistas (1616 - 1645). M. de M. Rangel; M. H. de F. Pereira; V. L. de Araujo (orgs). Caderno de resumos \& Anais do 6‥ Seminário Brasileiro de História da Historiografia - $O$ giro-linguístico e a historiografia: balanço e perspectivas. Ouro Preto: EdUFOP, 2012.

RAMOS, A. G. Administração e Estratégia do Desenvolvimento - Elementos de uma Sociologia Especial da Administração. Rio de Janeiro, Fundação Getúlio Vargas, 1966.

RESENDE, B. Drummond, cronista do Rio. Revista USP. São Paulo, no 53, p. 76-82, março/maio 2002.

RIBEIRO, D. O povo brasileiro: a formação e o sentido do Brasil. - São Paulo: Companhia das Letras, 1995.

RODRIGUES, R. P.; MILFONT, T. L.; FERREIRA, M. C.; PORTO J. B.; FISCHER, R. Brazilian jeitinho: Understanding and expanding an indigenous psychological construct. Revista Interamericana de Psicologia. 2011, vol. 45, no 1, p. 29-38.

ROSENN, K. S. The jeito: Brazil's Institutional Bypass of the Formal Legal System and its Developmental Implications. The American Journal of the Comparative Law. 1971, vol. 19, p. 516-549.

ROSSI, C. Jeitinho não basta. Opinião, Folha de São Paulo. São Paulo, 13 abr. 2008.

ROTH-GORDON, J. Conversational Sampling, RaceTrafficking, and the Invocation of the Gueto in Brazilian Hip Hop. In Global Linguistic Flows: hip hop cultures, youth identities, and the politics of language. Eds. Alim, H. S; Ibrahim, A.; Pennycook, A. Routledge. New York, 2009.

SARDINHA, T. B. Linguística de Corpus. - Barueri, SP: Manole, 2004.

SCHWARZ, R. A viravolta machadiana. Novos Estudos, CEBRAP, no 69, julho de 2004, pp. 15-34. 
Ao vencedor as batatas: forma literária e processo social nos inícios do romance brasileiro. 6ª ed. São Paulo: Duas Cidades; Editora 34, 2012.

SILVA, F. A diáspora brasileira e suas aspirações. The Brasilians ${ }^{\mathbf{1 4 4}}$. New York. Maio/Junho 2008, pp. 12-14.

SPERA, A. Adoniran Barbosa - Um centenário, ele continua atual. Veja São Paulo. Abril. 10 jan. 2010, atualizada em 18 jan. 2011.

SOUZA, V. A. Malandragem e cidadania. Tese de doutorado em Ciências Sociais pela Pontifícia Universidade Católica de São Paulo, 2008.

TAGNIN, S. E. O. 0 jeito que a gente diz: expressões convencionais e idiomáticas. São Paulo: Disal, 2005.

TATIT, L.; LOPES, I. C. Elos de melodia e letra: análise semiótica de seis canções. - Cotia, SP: Ateliê Editorial, 2008.

TAVARES, B. O jeito brasileiro. O jeitinho que virou little way. Revista Língua Portuguesa. São Paulo. Ano 8, n. 09, mar. 2013, p. 20-21.

TORRES, J. C. de O. Interpretação da realidade brasileira: introdução à história das ideias políticas no Brasil. 2ª ed. Rio de Janeiro, José Olympio; Brasília, INL, 1973.

ZANELLA, A. V. Escolarização formal e cidadania: possíveis relações, relações possíveis? Orgs. SILVEIRA, A. F. et al. Cidadania e participação social [online]. Rio de Janeiro: Centro Edelstein de Pesquisas Sociais, p. 84-91, 2008. Disponível em: http://books.scielo.org/id/hn3q6/pdf/silveira-9788599662885-00.pdf. Acesso em: 1 mai. 2014.

ZIMMERMANN, A. 'Do you know whom you are talking to?' - The subordination of law to social status in Brazil. The Western Australian Jurist, vol. 3, p. 213-231, 2012.

${ }^{144}$ The Brasilians com "s", provavelmente remetendo ao nome do país, na terra natal. 


\section{Anexo A}

\section{MOÇA DEITADA NA GRAMA}

A moça estava deitada na grama.

Eu vi e achei lindo. Fiquei repetindo para meu deleite pessoal: "Moça deitada na grama. Deitada na grama. Na grama." Pois o espetáculo me embevecia. Não é qualquer coisa que me embevece, a esta altura da vida. A moça, o estar deitada na grama, àquela hora da tarde, enquanto os carros passavam e cada ocupante ia ao seu compromisso, à sua alegria ou à sua amargura, a moça e sua posição me embevecem.

Não tinha nada de exibicionista, era a própria descontração, o encontro do corpo com a tranquilidade, fruída em estado de pureza. Quem quisesse reparar, reparasse; não estava ligando nem desafiando costumes nem nada. Simplesmente deitada na grama, olhos cerrados, mão na testa, vestido azul, sapatos brancos, pulseira, dois anéis, elegante, composta. De pernas, mostrava o normal. Não era imagem erótica.

Dormia? Não. Pequenos movimentos indicavam que ela permanecia consciente, mas eram tão pequenos, que se percebia seu bem-estar inalterável, sua intenção de continuar assim à sombra dos edifícios, no gramado.

Resolvi parar um pouco, encantado. Queria ver ainda por algum tempo a escultura da moça, plantada no parque como estátua de Henry Moore, uma estátua sem obrigação de ser imóvel. E que arfava docemente. Ah, o arfar da moça, que lhe erguia com leveza o busto, lembrando o sangue a circular pelas artérias silenciosas, tão vivo; e tão calmo, como se também ele quisesse descansar na grama, curtir para sempre aquele instante de felicidade.

Eis que se aproxima um guarda, inclina-se, toca no ombro da moça. De leve. Ela abre os olhos, sorri bem disposta:

- Quer deitar também? Aproveita a tarde, tão gostosa.

Ele se mostra embaraçado, fala aos pedaços:

- Não, moça... me desculpe. É o seguinte. A senhora... quer fazer o favor de levantar?

- Levantar por quê? Está tão bom aqui.

- A senhora não pode ficar aí assim não. Levante, estou lhe pedindo.

- Por que hei de me levantar? Minha posição é cômoda, eu estou bem aqui. Olhe ali adiante aquele homem, ele também está deitado na grama.

- Aquele é diferente, a senhora não percebe?

- Percebo que é um homem, e daí? Homem pode, mulher não?

- Bom, poder ninguém pode, é proibido, mas sendo homem, além disso mindingo...

- Ah, compreendo agora. Sendo homem e mindingo, tem direito a deitar no gramado, mas sendo mulher, tendo profissão liberal, pagando imposto de renda, predial, lixo, sindicato, etc., nada feito. É isso que o senhor quer dizer?

- Deus me livre, moça. Quem sou eu para dizer uma coisa dessas? Só que é a primeira vez, e eu tenho dez anos de serviço, que vejo uma dona como a senhora, bem-vestida, bem apessoada, assim espichada na grama. Com a devida licença, achei que não ficava bem imitar os homens, os mindingos, que a gente tem pena e deixa por aí... especial.

- Faça de conta que eu também sou uma mindinga - e a moça abriu para ele um sorriso

- Para o bem da senhora, não convém se arriscar desse jeito.

- Eu acho que não estou me arriscando nada, pois tem o senhor aí me garantindo.

- Obrigado. Eu garanto até certo ponto, mas basta a gente virar as costas, vem aí um elemento e furta o seu reloginho, a sua bolsa, as suas coisas.

- Sei me defender, meu santo. Tenho o meu cursinho de caratê.

- Tá certo, mas não deve facilitar. A senhora se levanta em nome da lei.

- Espere aí. Ou todos se levantam ou eu continuo deitada em nome da lei da igualdade.

- Essa lei eu não conheço não, dona. Não posso conhecer todas as leis. Essa que a senhora fala, eu acho que não pegou.

- Mas deve pegar. É preciso que pegue, mais cedo ou mais tarde.

- Não vai levantar? 
- Não.

Ele coçou a cabeça. Agarrar a moça era violência, ela ia reagir, juntava povo, criava caso. Afinal, não estava fazendo nada de imoral nem subversivo. Por outro lado, não pegava bem moça deitada na grama - ele devia ter na mente a ideia da moça vestida de gaze, aérea, meio arcanjo, nunca deitável no chão de grama, como qualquer vagabundo fedorento.

- A senhora não devia me fazer uma coisa dessas.

- Fazer o quê?

- Me expor nesta situação.

- Eu não fiz nada, estava numa boa oriental, o senhor chega e ...

- É muito difícil lidar com mulheres, elas tem resposta para tudo.

- Vamos fazer uma coisa. O senhor faz que não me viu, vai andando, eu saio daqui a pouco. Só mais dez minutos, para não parecer que estou cedendo a um ato de força.

- Pode ficar o tempo que quiser - decidiu ele. - A senhora falou na tal lei da igualdade, então vamos cumprir. Só que aquele malandro ali adiante tem de se mandar urgente, eu vou lá dar um susto nele, já gozou demais da igualdade, agora chega!

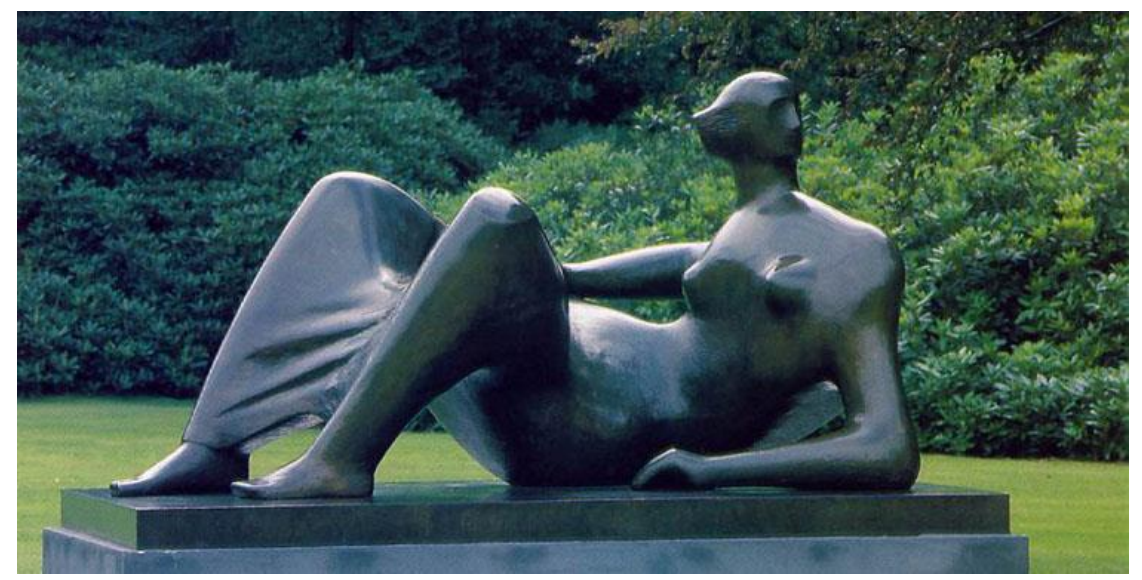

Figura 1: A figura reclinada - Henry Moore

http://artesteves.blogspot.com.br/2013/11/henru-moore-figura-reclinada.html

\title{
Anexo B
}

\section{A CARTEIRA}

\author{
Machado de Assis
}

...DE REPENTE, Honório olhou para o chão e viu uma carteira. Abaixar-se, apanhá-la e guardá-la foi obra de alguns instantes. Ninguém o viu, salvo um homem que estava à porta de uma loja, e que, sem o conhecer, lhe disse rindo:

- Olhe, se não dá por ela; perdia-a de uma vez.

- É verdade, concordou Honório envergonhado.

Para avaliar a oportunidade desta carteira, é preciso saber que Honório tem de pagar amanhã uma dívida, quatrocentos e tantos mil-réis, e a carteira trazia o bojo recheado. A dívida não parece grande para um homem da posição de Honório, que advoga; mas todas as quantias são grandes ou pequenas, segundo as circunstâncias, e as dele não podiam ser piores. Gastos de família excessivos, a princípio por servir a parentes, e depois por agradar à mulher, que vivia aborrecida da solidão; baile daqui, jantar dali, chapéus, leques, tanta cousa mais, que não havia remédio senão ir descontando o futuro. Endividou-se. Começou pelas contas de lojas e armazéns; passou aos empréstimos, duzentos 
a um, trezentos a outro, quinhentos a outro, e tudo a crescer, e os bailes a darem-se, e os jantares a comerem-se, um turbilhão perpétuo, uma voragem.

- Tu agora vais bem, não? dizia-Ihe ultimamente o Gustavo C., advogado e familiar da casa.

- Agora vou, mentiu o Honório.

A verdade é que ia mal. Poucas causas, de pequena monta, e constituintes remissos; por desgraça perdera ultimamente um processo, $\mathrm{cm}$ que fundara grandes esperanças. Não só recebeu pouco, mas até parece que ele the tirou alguma cousa à reputação jurídica; em todo caso, andavam mofinas nos jornais.

D. Amélia não sabia nada; ele não contava nada à mulher, bons ou maus negócios. Não contava nada a ninguém. Fingia-se tão alegre como se nadasse em um mar de prosperidades. Quando o Gustavo, que ia todas as noites à casa dele, dizia uma ou duas pilhérias, ele respondia com três e quatro; e depois ia ouvir os trechos de música alemã, que D. Amélia tocava muito bem ao piano, e que o Gustavo escutava com indizível prazer, ou jogavam cartas, ou simplesmente falavam de política.

Um dia, a mulher foi achá-lo dando muitos beijos à filha, criança de quatro anos, e viu-lhe os olhos molhados; ficou espantada, e perguntou-lhe o que era.

- Nada, nada.

Compreende-se que era o medo do futuro e o horror da miséria. Mas as esperanças voltavam com facilidade. A ideia de que os dias melhores tinham de vir dava-lhe conforto para a luta. Estava com, trinta e quatro anos; era o princípio da carreira: todos os princípios são difíceis. E toca a trabalhar, a esperar, a gastar, pedir fiado ou: emprestado, para pagar mal, e a más horas.

A dívida urgente de hoje são uns malditos quatrocentos e tantos mil-réis de carros. Nunca demorou tanto a conta, nem ela cresceu tanto, como agora; e, a rigor, o credor não lhe punha a faca aos peitos; mas disse-Ihe hoje uma palavra azeda, com um gesto mau, e Honório quer pagar-Ihe hoje mesmo. Eram cinco horas da tarde. Tinha-se lembrado de ir a um agiota, mas voltou sem ousar pedir nada. Ao enfiar pela Rua da Assembléia é que viu a carteira no chão, apanhou-a, meteu no bolso, e foi andando.

Durante os primeiros minutos, Honório não pensou nada; foi andando, andando, andando, até - Largo da Carioca. No Largo parou alguns instantes, -- enfiou depois pela Rua da Carioca, mas voltou logo, e entrou na Rua Uruguaiana. Sem saber como, achou-se daí a pouco no Largo de S. Francisco de Paula; e ainda, sem saber como, entrou em um Café.

Pediu alguma cousa e encostou-se à parede, olhando para fora. Tinha medo de abrir a carteira; podia não achar nada, apenas papéis e sem valor para ele. Ao mesmo tempo, e esta era a causa principal das reflexões, a consciência perguntava-lhe se podia utilizar-se do dinheiro que achasse. Não lhe perguntava com o ar de quem não sabe, mas antes com uma expressão irônica e de censura. Podia lançar mão do dinheiro, e ir pagar com ele a dívida?

Eis o ponto. A consciência acabou por lhe dizer que não podia, que devia levar a carteira à polícia, ou anunciá-la; mas tão depressa acabava de lhe dizer isto, vinham os apuros da ocasião, e puxavam por ele, e convidavam-no a ir pagar a cocheira. Chegavam mesmo a dizer-lhe que, se fosse ele que a tivesse perdido, ninguém iria entregar-Iha; insinuação que lhe deu ânimo.

Tudo isso antes de abrir a carteira. Tirou-a do bolso, finalmente, mas com medo, quase às escondidas; abriu-a, e ficou trêmulo. Tinha dinheiro, muito dinheiro; não contou, mas viu duas notas de duzentos mil-réis, algumas de cinqüenta e vinte; calculou uns setecentos mil réis ou mais; quando menos, seiscentos. Era a dívida paga; eram menos algumas despesas urgentes. Honório teve tentações de fechar os olhos, correr à cocheira, pagar, e, depois de paga a dívida, adeus; reconciliarse-ia consigo. Fechou a carteira, e com medo de a perder, tornou a guardá-la.

Mas daí a pouco tirou-a outra vez, e abriu-a, com vontade de contar o dinheiro. Contar para quê? era dele? Afinal venceu-se e contou: eram setecentos e trinta mil-réis. Honório teve um calafrio. Ninguém viu, ninguém soube; podia ser um lance da fortuna, a sua boa sorte, um anjo... Honório teve pena de não crer nos anjos... Mas por que não havia de crer neles? E voltava ao dinheiro, olhava, passava-o pelas mãos; depois, resolvia o contrário, não usar do achado, restituí-lo. Restituí-lo a quem? Tratou de ver se havia na carteira algum sinal.

"Se houver um nome, uma indicação qualquer, não posso utilizar- me do dinheiro," pensou ele.

Esquadrinhou os bolsos da carteira. Achou cartas, que não abriu, bilhetinhos dobrados, que não leu, e por fim um cartão de visita; leu o nome; era do Gustavo. Mas então, a carteira? ... Examinou-a por fora, e pareceu-lhe efetivamente do amigo. Voltou ao interior; achou mais dous cartões, mais três, mais cinco. Não havia duvidar; era dele. 
A descoberta entristeceu-o. Não podia ficar com o dinheiro, sem praticar um ato ilícito, e, naquele caso, doloroso ao seu coração porque era em dano de um amigo. Todo o castelo levantado esboroou-se como se fosse de cartas. Bebeu a última gota de café, sem reparar que estava frio. Saiu, e só então reparou que era quase noite. Caminhou para casa. Parece que a necessidade ainda the deu uns dous empurrões, mas ele resistiu.

"Paciência, disse ele consigo; verei amanhã o que posso fazer."

Chegando a casa, já ali achou o Gustavo, um pouco preocupado e a própria D. Amélia o parecia também. Entrou rindo, e perguntou ao amigo se lhe faltava alguma cousa.

- Nada.

- Nada?

- Por quê?

- Mete a mão no bolso; não te falta nada?

- Falta-me a carteira, disse o Gustavo sem meter a mão no bolso. Sabes se alguém a achou? -- Achei-a eu, disse Honório entregando-Iha.

Gustavo pegou dela precipitadamente, e olhou desconfiado para o amigo. Esse olhar foi para Honório como um golpe de estilete; depois de tanta luta com a necessidade, era um triste prêmio. Sorriu amargamente; e, como o outro the perguntasse onde a achara, deu-lhe as explicações precisas.

- Mas conheceste-a?

- Não; achei os teus bilhetes de visita.

Honório deu duas voltas, e foi mudar de toilette para o jantar. Então Gustavo sacou novamente a carteira, abriu-a, foi a um dos bolsos, tirou um dos bilhetinhos, que o outro não quis abrir nem ler, e estendeu-o a D. Amélia, que, ansiosa e trêmula, rasgou-o em trinta mil pedaços: era um bilhetinho de amor. 